\title{
IDENTIFICAÇÃO DAS ÁREAS CONTAMINADAS NO MUNICÍPIO DE RIBEIRÃO PIRES - SÃO PAULO
}

\author{
ERO HERMÍNIO CROZERA
}

Orientador: Prof. Dr. Uriel Duarte

TESE DE DOUTORAMENTO

COMISSÃO JULGADORA

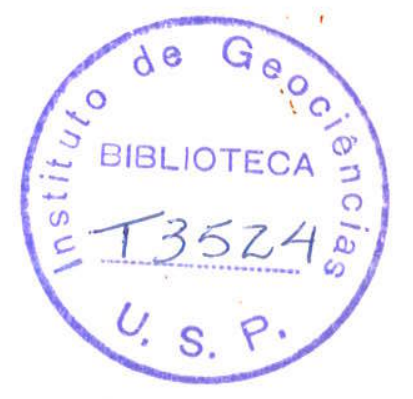

Nome

Presidente: Prof. Dr. Uriel Duarte

Examinadores: Prof. Dr. Leandro Eugênio Silva Cerri

Prof. Dr. Luís Enrique Sánchez

Prof. Dr. Ricardo César Aoki Hirata

Dr. Rodrigo César de Araújo Cunha

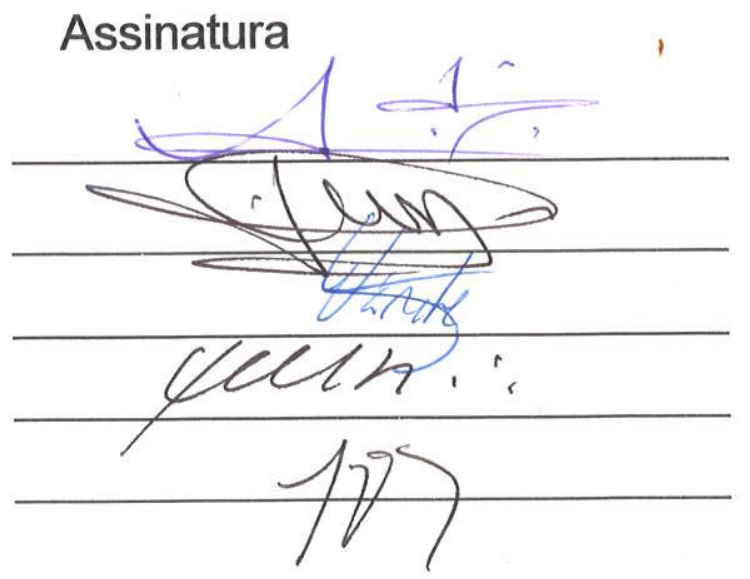

SÃO PAULO

2001 


\section{UNIVERSIDADE DE SÃO PAULO \\ INSTITUTO DE GEOCIÊNCIAS}

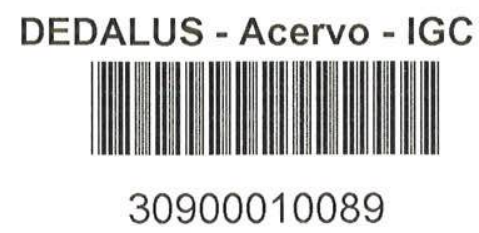

\section{IDENTIFICAÇÃO DAS ÁREAS CONTAMINADAS NO MUNICÍPIO DE RIBEIRÃO PIRES - SÃO PAULO.}

Ero Hermínio Crozera

Orientador: Prof. Dr. Uriel Duarte

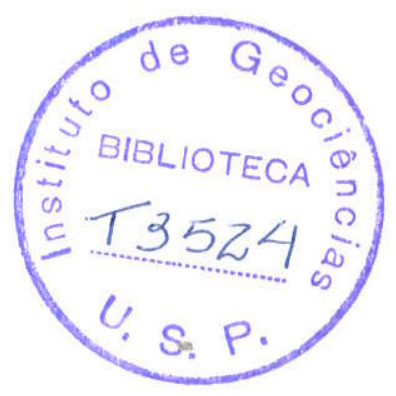

TESE DE DOUTORAMENTO

Programa de Pós-Graduação em Recursos Minerais e Hidrogeologia

São Paulo

2001 
Para Rita, Naira e Ilia. 


\section{AGRADECIMENTOS}

À Universidade de São Paulo.

Ao Instituto de Geociências, e o Departamento de Geologia Sedimentar e Ambiental.

Ao meu orientador Prof. Dr. Uriel Duarte pelo apoio, orientação e amizade.

Ao Prof. Dr. Arlei Benedito de Macedo, por possibilitar meu ingresso no Instituto de Geociências.

Ao Prof. Dr. Alberto Pacheco, pela amizade e orientação no exame de qualificação.

À CAPES - Demanda Social, pela bolsa de estudos concedidada,

À Companhia de Tecnologia de Saneamento Ambiental - CETESB, por meio do projeto de cooperação técnica com a GTZ, pelo infra-estrutura necessária para o desenvolvimento de minha pesquisa.

Aos coordenadores do projeto CETESB/GTZ, Eng ${ }^{\circ}$ Eduardo Luís Serpa, Eng $^{\circ}$ Marco Antonio Günther e Dr. Geol. Andreas Marker.

Ao Ger. do Grupo de Apoio Técnico em Áreas Contaminandas Dr. Geol. Elton Gloeden pela orientação e sugestões tanto no decorrer da pesquisa quanto no exame de qualificação,

Ao Eng ${ }^{\circ}$ Alcides Diniz Garcia Junior, pelas informações técnicas.

Ao Geol. Álvaro Gutierrez Lopez, ao Téc. Inf. Darci Andrade Oliveira, ao Téc. Proces. Hélio Montenegro Rocha, ao Téc. Proces. Hélvio Aventurato, ao Eng $^{\circ}$ João Wagner Silva Alves, a Quím. Lúcia Y. A. Straceri, a Eng ${ }^{a}$ Quím. Maria José de Barros Fraccaroli, ao Téc. Lab. Paulo Henrique, ao Eng ${ }^{\circ}$ Rodrigo C. Araújo Cunha, Eng ${ }^{\circ}$ Sílvio K. Ogura, ao Eng ${ }^{\circ}$ Vicente de Aquino Neto, ao Geof. Wagner França Aquino, ao Téc. Amb. Walter Luiz Monteiro, aos estagiários Fernando Faria Roos, Vivian Pataro, Marcelo Albergaria e a todo o pessoal da EERO,

À Agência Ambiental - CETESB / Santo André representada pelo Eng ${ }^{\circ}$ Brun.

Às secretárias: Patrícia González, Ana Paula Cabanal, Magaly Poli Fernandes Rizzo e Dorothea Rosenthal um muito obrigado especial,

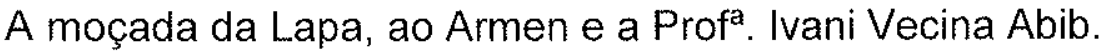

Ao Richard "Zeitgeist" pela força, ao Zappa, ao Reed, ao Crimson pela inspiração; valeu! 


\section{ÍNDICE}

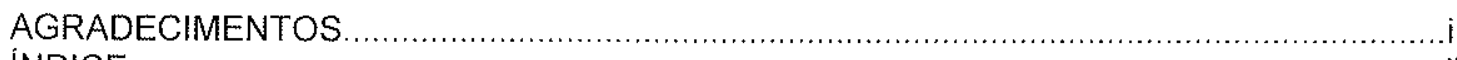

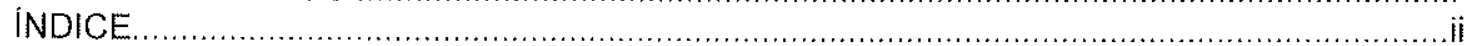

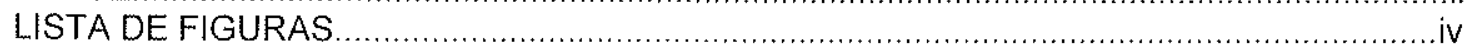

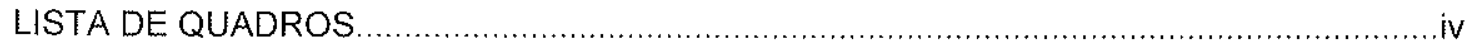

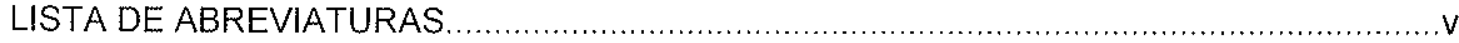

RESUMO

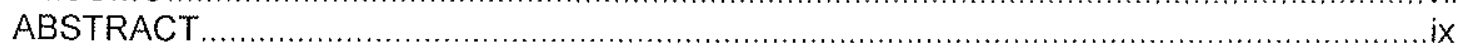

1. INTRODUÇÃO

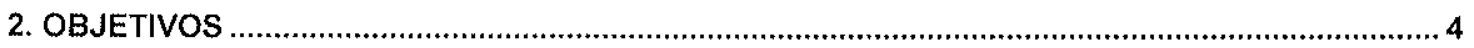

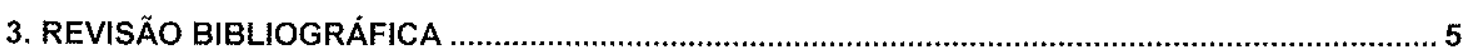

3.1 CONCEITUAÇÄO: ÁREAS CONTAMINADAS, REUTILIZAÇÄO E REVITALIZAÇÄO DE ÁREAS INDUSTRIAIS DESATIVADAS

3.1.1 Aspectos legais do tema áreas contaminadas no Brasil $\ldots$

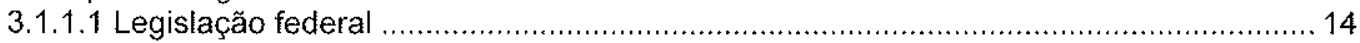

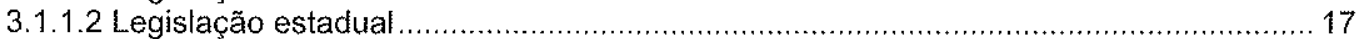

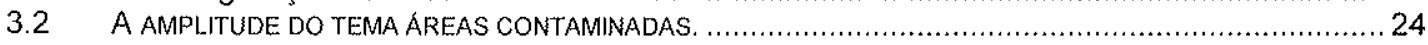

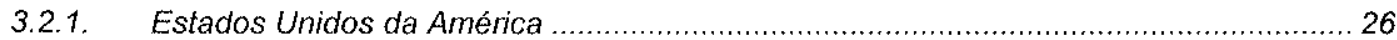

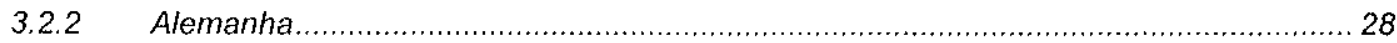

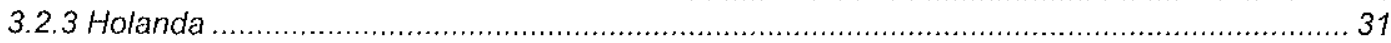

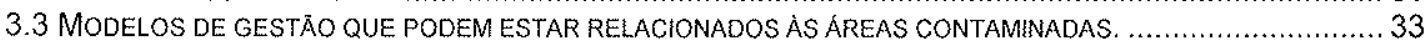

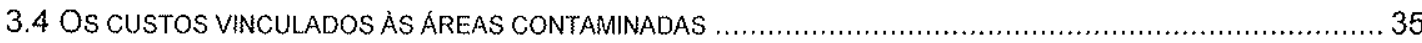

3.5 INSTRUMENTOS ECONOOMICOS VINCULADOS AO GERENCIAMENTO DE ȦREAS CONTAMINADAS E AS FONTES DE

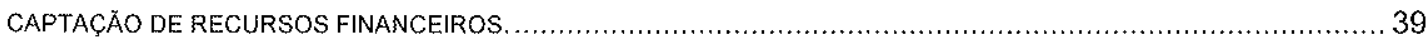

3.5.1 Fontes Nacionais e Internacionais de Cooperação Financeira ................................. 40

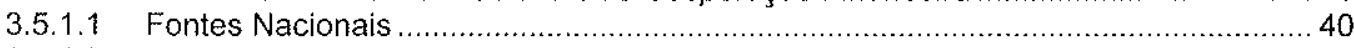

3.5.1.2 Fontes Internacionais de Cooperação Financeira......................................... 44

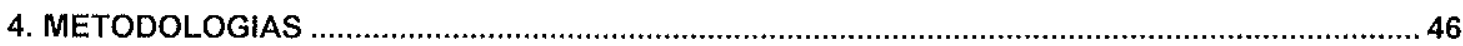

4.1 O GERENCIAMENTO DE ÁREAS CONTAMNADAS - COMPANHIA dE TECNOLOGIA DE SANEAMENTO AMBIENTAL

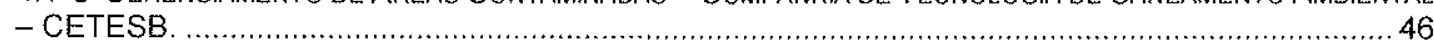

4.1.1 O processo de identificação de áreas contaminadas......................................................... 49

4.1.1.1 A definição da região de interesse.............................................................................. 49

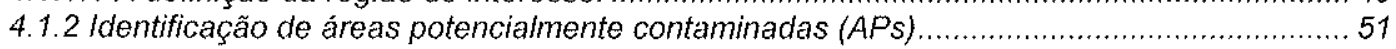

4.1.2.1 Definição das atividades potencialmente contaminadoras (APCs) .......................... 52

4.1.2.2 Levantamento de dados existentes ................................................................. 52

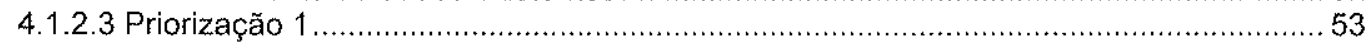

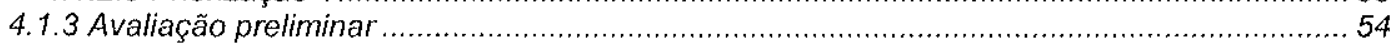

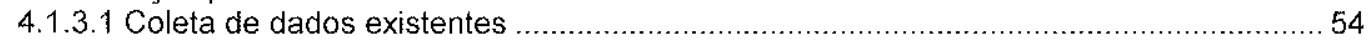

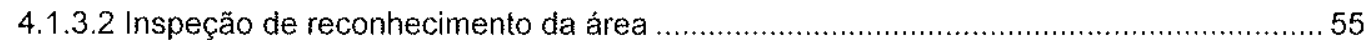

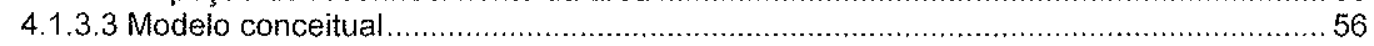

4.1 .4 Classificação 1 ................................................................................................... 56

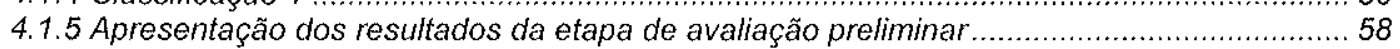

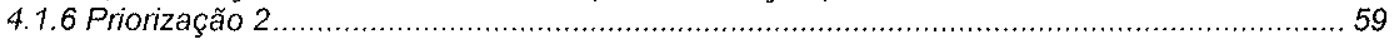

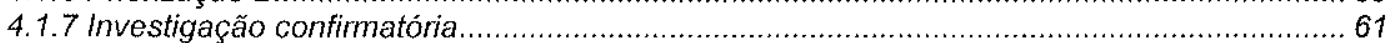

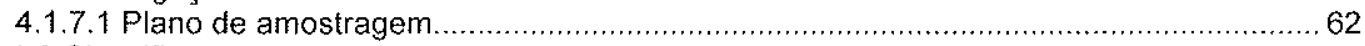

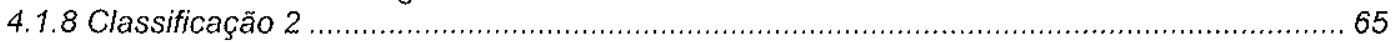

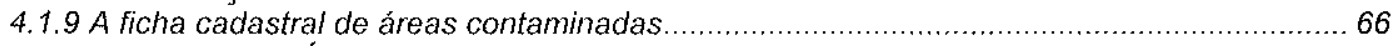

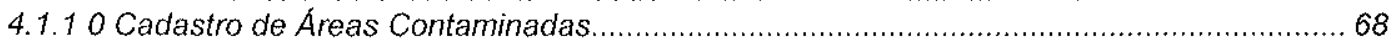

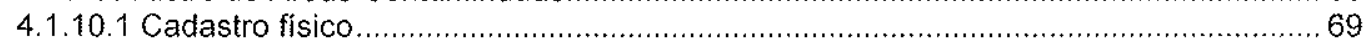

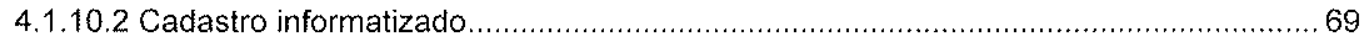

4.2 POlítica de ProteçÃo de Solos - COMUnidade Autónoma do País BASCO (CAPB), "SOCIEDAd

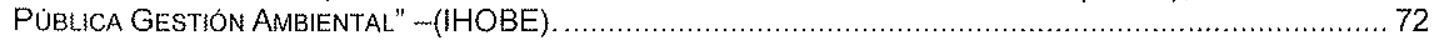

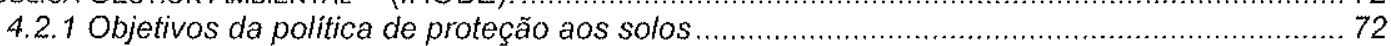

4.2.2 Definição e estrutura de gestão da política global para a proteção do solo....................... 73

4.2.3 Incorporação de atividades potencialmente contaminadoras ao processo de investigação. 73

4.2.4 As etapas de investigação em solos contaminados.................................................. 73

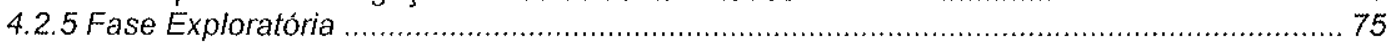

4.2.6 Valores indicativos de avaliação (VIE - A, VIE - B, VIE - C) ........................................ 76

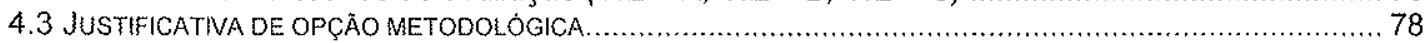


5. A EXECUÇÃO DO PROCESSO DE IDENTIFICAÇÃO DE ÁREAS CONTAMINADAS.

5.1 MATERIAIS UTILIZADOS NO PROCESSO DE IDENTIFICAÇÃO DE ÁREAS NA REGIÃO DE INTERESSE . .............79

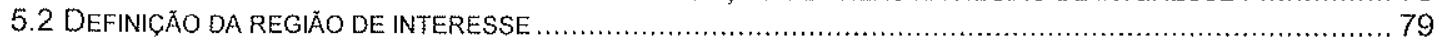

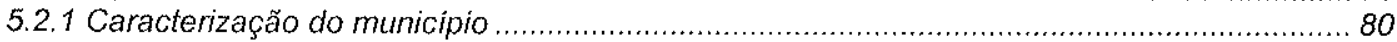

5.2.2 Objetivos do gerenciamento de áreas contaminadas em Ribeirão Pires ............................... 87

5.3 IDENTIFICAÇÃO DE ÁREAS POTENCIALMENTE CONTAMINADAS (APCS) .......................................8 87

5.3.1 Priorização 1 - Definição das atividades potencialmente contaminadoras.......................... 91

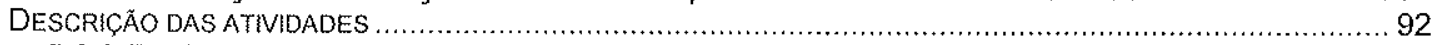

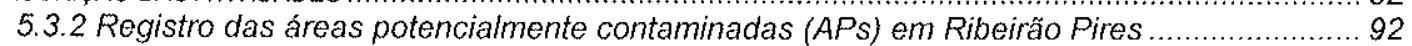

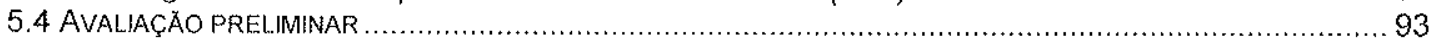

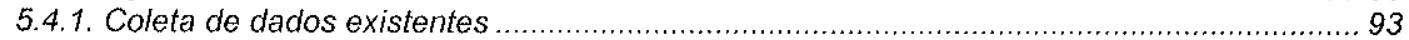

5.4.2 As Inspeções de reconhecimento das áreas potencialmente contaminadas.......................... 93

5.4.2.1 As tabelas de atividades e substâncias ............................................................... 100

5.4.3 Inspeção de reconhecimento ..................................................................................... 102

5.4.3.1 Inspeção de reconhecimento: áreas comerciais ................................................ 102

5.4.3.2 Inspeção de reconhecimento: postos de serviço .............................................. 106

5.4.3.3 Inspeção de reconhecimento: áreas industriais...................................................... 109

5.4.3.4 Inspeção de área: Outras fontes/cemitério ................................................. 132

5.4.3.5 Inspeção de área: Disposição de residuos ........................................................ 133

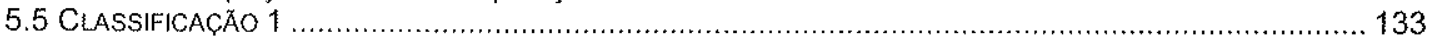

6. PRIORIZAÇÃO 2: OS CUSTOS DO PROCESSO DE IDENTIFICAÇÃO. ..................................... 135

6.1 BASES FISICAS - OS RECURSOS FINANCEIROS UTILIZADOS NA EXECUÇÃO DO PROCESSO DE IDENTIFICAÇÄO

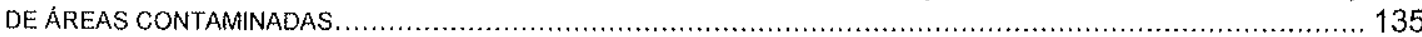

6.1.1 Tempo de execução do processo de identificação .......................................................... 135

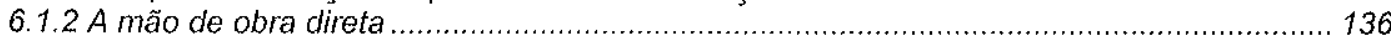

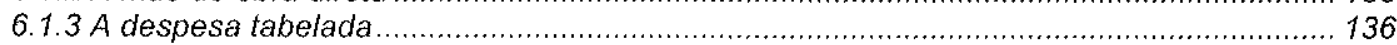

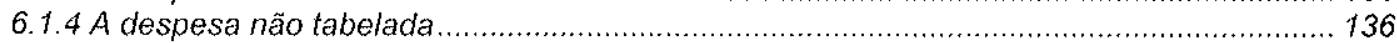

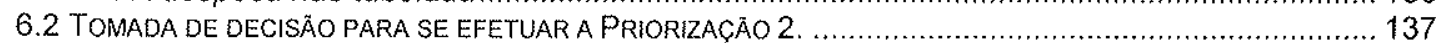

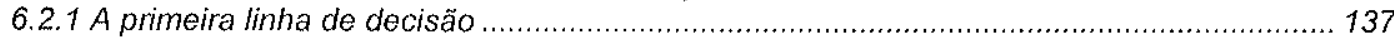

6.2.2 A segunda linha de decisão ............................................................................. 138

6.2.3 A justificativa da opção pelas áreas com alta pontuação.................................................... 141

6.2 .4 Valoração da segunda linha de decisão....................................................... 144

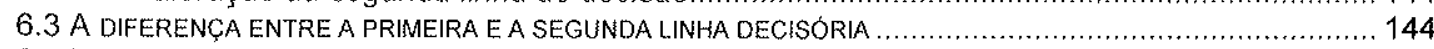

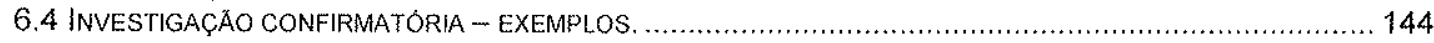

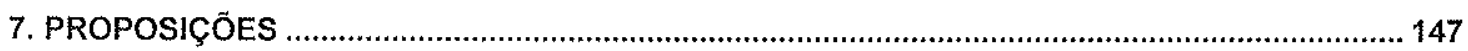

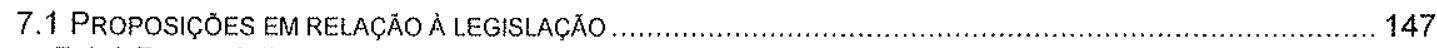

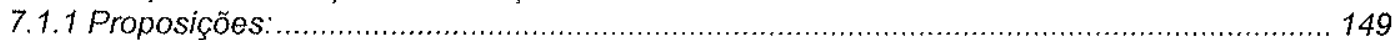

7.2 PROPOSIÇÓES PARA OS POSTOS DE SERVIÇO: ...................................................................... 152

7.2.1 Proposição: Propor aos postos de serviço do municipio de Ribeirão Pires: ...................... 152

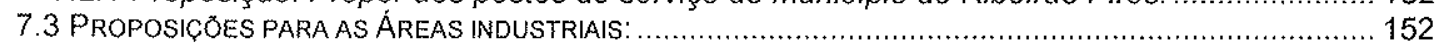

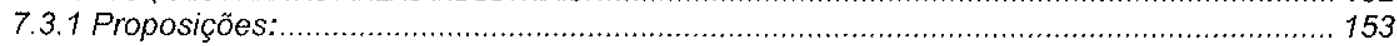

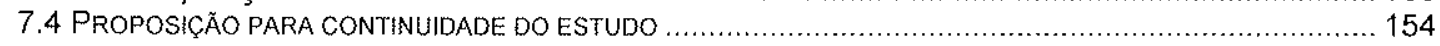

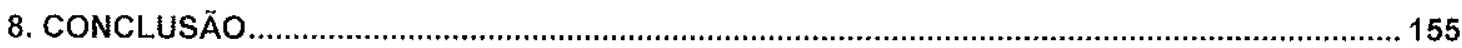

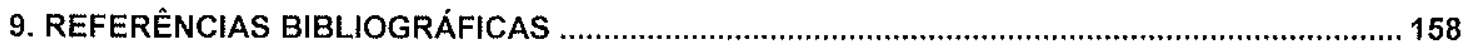

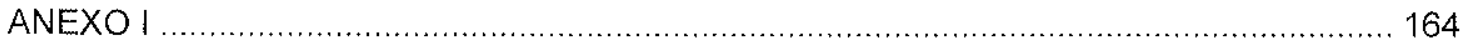

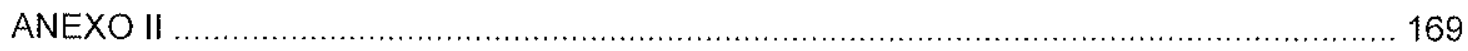

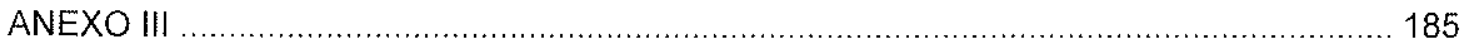




\section{LISTA DE FIGURAS}

FIGURA 4.1 FluXOGRAMA DAS ETAPAS DO GERENCIAMENTO DE ÁREAS CONTAMINADAS .............48

FIGURA 4.3 FLUXOGRAMA DE TOMADA DE DECISÃO PARA A CLASSIFICAÇÃO $1 \ldots \ldots \ldots \ldots \ldots \ldots \ldots \ldots . . \ldots 8$

FIGURA 4.4 PROPOSTA DE ESTRATÉGIAS PARA A ELABORAÇÄO DE PLANO DE AMOSTRAGEM DE SOL..

E ÁGUA SUBTERRÃNEA NA ETAPA DE INVESTIGAÇÄO CONFIRMATÓRIA (CETESB, 1999)...... 64

FIGURA 4.5 O ESQUEMA DE ENTRADA DE DADOS NO CADASTRO DE ÁREAS CONTAMINADAS......... 70

FIGURA 4.6 PROCESSAMENTO DE DADOS REFERENTES ȦS ÁREAS CONTAMINADAS .................... 72

FIGURA 4.6 ESQUEMA DAS ETAPAS DE INVESTIGAÇÄO EM SOLOS CONTAMINADOS SEGUNDO IHOBE.

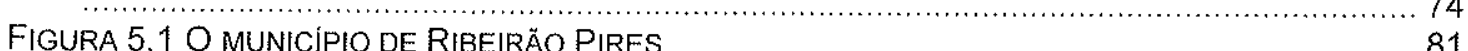

FIGURA 5.2 OS AMBIENTES LITOLÓGICOS DO MUNICIPIO DE RIBEIRÄO PIRES. .......................... 83

FIGURA 5.3 FLUXOGRAMA DE PRODUÇÃO DE DISPERSANTES, COM POSSIVEIS LIBERAÇÕES DE

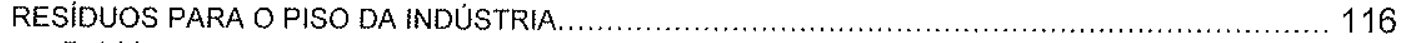

FIGURA 5.4 UNIDADE RECUPERADORA DE SOLVENTES, POR CONDENSAÇÃO EM INDÚSTRIA DE PLÁSTICO.

FIGURA 5.5 PROCESSO AUTOMÁTICO DE ELETRODEPOSIÇÃO QUE ERA EXECUTADO EM 1000443 , DEMONSTRANDO AS PROVÁVEIS FONTES DE CONTAMINAÇÃO (A PRODUÇÃO E A ARMAZENAGEM DE SUBSTANNCIAS) AOS BENS A PROTEGER.

FIGURA 5.6 CLASSIFICAÇÃO DAS ÁREAS POTENCIALMENTE CONTAMINADAS, SUSPEITASE EXCLUIDAS, ATIVIDADES E QUANTIDADE.

FIGURA 6.1 CRITÉRIOS DE PRIORIZAÇÃO E OS INTERVALOS DE PONTUAÇÃO............................. 140

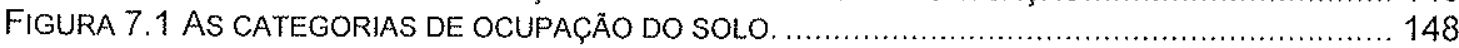

\section{LISTA DE QUADROS}

QUADRO 4.1 ESTRATÉGIAS DE AMOSTRAGEM DE SOLO E AGUAS SUBTERRÂNEAS NA ETAPA DE INVESTIGAÇÄO CONFIRMATÓRIA (CETESB, 1999)

QUADRO 4.2 LISTA DOS CONTAMINANTES MAIS COMUNS NOS SOLOS DO PAIS BASCO .............. 77

QUADRO 5.1 DADOS SÓCIO - ECONÓMICOS DA REGIÃO DE INTERESSE $\ldots \ldots \ldots \ldots \ldots \ldots \ldots \ldots \ldots \ldots . \ldots \ldots$

QUADRO 5.2 LISTA DAS ATIVIDADES INDUSTRIAIS/COMERCIAIS POTENCIALMENTE CONTAMINADORAS,

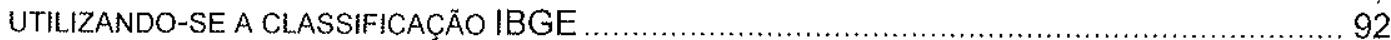

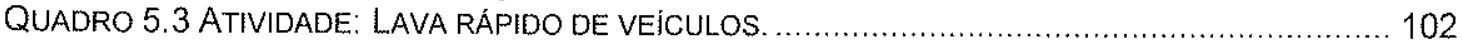

QUADRO 5.4 POSTOS DE SERVIÇOS AUTOMOTIVO EM RIBEIRÃO PIRES.................................... 107

QUADRO 5.5 TOTAL DE TANQUES, VOLUME E TIPO DE COMBUSTIVEL, PRESENTES NOS POSTOS DE SERVIÇOS AUTOMOTIVO NO MUNICIPIO DE RIBEIRÃO PIRES .................................... 108

QUADRO 5.6 MATÉRIAS PRIMAS UTILIZADAS, EM UMA INDUSTTRIA QUÍMICA ATIVA QUE PRODUZ MATERIAIS PARA TRATAMENTO DE EFLUENTES, CLARIFICANTES E DISPERSANTES. ............. 115

QUADRO 6.1 RESULTADO DO ENSAIO DOS INTERVALOS DE PONTUAÇÃO ............................. 141 


\section{LISTA DE ABREVIATURAS}

\begin{tabular}{|c|c|}
\hline $\mathrm{AC}$ & Ärea(s) Contaminada(s) \\
\hline AP & Área(s) Potencialmente Contaminada(s) \\
\hline APA & Área de Proteção Ambiental \\
\hline APC & Atividade industrial / comercial Potencialmente Contaminadora \\
\hline APM & Área de Proteção dos Mananciais \\
\hline Art. & Artigo \\
\hline AS & Área(s) Suspeita(s) de Contaminação \\
\hline BP & Bem a Proteger (item da Ficha Cadastral de AC) \\
\hline CETESB & Companhia de Tecnologia de Saneamento Ambiental \\
\hline CGC & $\begin{array}{l}\text { Cadastro Geral de Contribuinte } \\
\text { (item da Ficha Cadastral de AC) }\end{array}$ \\
\hline CONAMA & Conselho Nacional do Meio Ambiente \\
\hline CONSEMA & Conselho Estadual do Meio Ambiente de São Paulo \\
\hline $\mathrm{CP} 1(2,3)$ & $\begin{array}{l}\text { Critério Principal } 1(2,3) \\
\text { (da Ficha Cadastral de AC) }\end{array}$ \\
\hline EET & Divisão de Tecnologias de Controle (da CETESB) \\
\hline EETI & Setor de Implantação de Tecnologias (da CETESB-DD) \\
\hline EMPLASA & $\begin{array}{l}\text { Empresa Metropolitana de Planejamento } \\
\text { da Grande São Paulo S/A }\end{array}$ \\
\hline GTZ & Deutsche Gesellschaft für Technische Zusammenarbeit \\
\hline IBAMA & $\begin{array}{l}\text { Instituto Brasileiro do Meio Ambiente e dos Recursos Naturais } \\
\text { Renováveis }\end{array}$ \\
\hline IBGE & $\begin{array}{l}\text { Instituo Brasileiro de Geografia e Estatística } \\
\text { (item da Ficha Cadastral de AC, veja 5101) }\end{array}$ \\
\hline IHOBE & $\begin{array}{l}\text { SOCIEDAD PÚBLICA DE GESTIÓN AMBIENTAL - País Vasco, } \\
\text { Espanha }\end{array}$ \\
\hline ISAL & $\begin{array}{l}\text { Informationssystem Altlasten } \\
\text { (sistema de Informações sobre AC) de NRW - Alemanha }\end{array}$ \\
\hline M.A. & Meio Ambiente \\
\hline
\end{tabular}


MCE

NRW

PA

PAS

PASP

PROCOP

PS

RMSP

SGI

SMA

SP
Memorial de Caracterização do Empreendimento (item do processo de licenciamento CETESB)

Nordrhein-Westfalen (Estado da República Federal da Alemanha)

Propagação via ar (item da Ficha Cadastral de AC)

Propagação via águas subterrâneas

(item da Ficha Cadastral de AC)

Propagação via águas superficiais

(item da Ficha Cadastral de AC)

Programa de Controle da Poluição Inđustrial

Propagação via solo (item da Ficha Cadastral de AC)

Região Metropolitana de São Paulo

Sistema Geográfico de Informações

Secrataria de Estado do Meio Ambiente de São Paulo

Estado de São Paulo 


\section{RESUMO}

O município de Ribeirão Pires, localizado na RMSP, foi a região escolhida para este estudo, tem a totalidade de sua extensão territorial inclusa em Área de Proteção de Mananciais, foi declarado estância turística e possui um parque industrial intimamente ligado à indústria automobilística do Grande $\mathrm{ABC}$.

Este quadro foi o pano de fundo para a edificação do objetivo do estudo, fomentando hipóteses e objetivos específicos, para a identificação e a investigação de áreas contaminadas.

A realização da pesquisa bibliográfica versou sobre a conceituação do tema área contaminada, fontes de contaminação, legislação federal e estadual e o tema gerenciamento de áreas contaminadas.

Em relação à metodologia, foram comparadas duas linhas metodológicas: uma é empregada com o auxílio de um banco de dados que possibilita quantificar e qualificar as áreas. A outra é empregada em estudos caso a caso quando se objetiva a realização de um inventário.

$\mathrm{Na}$ região de interesse inicialmente foram escolhidos elementos ou bens que deveriam ser protegidos e em seguida, dentro do universo de atividades industriais e/ou comerciais desenvolvidas no municipio que possuem potencial de contaminação desses bens a proteger. Em uma listagem com todas as atividades desenvolvidas na área, foram priorizadas aquelas que pela literatura nacional e internacional são consideradas como as de maior potencial de contaminação aos bens a proteger.

As atividades escolhidas, tanto ativas como desativadas, para o estudo foram: áreas industriais dos grupos químico e metalúrgico, todos os postos de serviços automotivos do município, as atividades comerciais de transporte e as áreas de disposição de resíduos inclusas na bacia hidrográfica Billings e 
os bens a proteger escolhidos foram; o solo e as águas (superficial e subterrâneas).

No desenvolvimento da avaliação preliminar de cada área, foram utilizados como base de dados, para o estudo histórico, os processos de licenciamento junto ao órgão fiscalizador e as inspeções de reconhecimento em campo.

As informações obtidas, nas avaliações de campo foram anexadas primeiramente em um cadastro físico, na forma de fichas cadastrais $e$ posteriormente repassadas a um cadastro digital, atribuindo a cada uma dessas áreas, um código alfanumérico e um valor atribuído por um critério de pontuação que pondera: as características das substâncias utilizadas no presente (tanto no passado como no presente), as fontes de contaminação, as vias de transporte dos contaminantes e os riscos relativos aos bens a proteger.

Os custos do estudo são identificados em duas situações; os custos relativos à realização da avaliação preliminar e os custos para se efetuar investigação confirmatória nas áreas priorizadas.

As proposições, neste estudo, podem ser identificadas como medidas proativas, corretivas e preventivas em relação à emendas, à legislação estadual, à reutilização de áreas industriais e comerciais desativadas e aos postos de serviços automotivo. 


\begin{abstract}
The focus of this study is the municipality of Ribeirão Pires, located within the RMSP, which is wholly located within a watershed protection area, besides having been declared a site of touristic interest. This also got considerable industrial activity, intimately related to the large-scale vehicle manufacturing operations conducted in nearby "ABC" district.
\end{abstract}

This picture has been adopted as the basis for this study and has helped to the formulation of hypotheses and specific goods, it is intendent in this study to identify and investigate contaminated sites.

The biographical research helped in the knowledge of the "contaminated site" concept, contaminated sources, Federal \& State legislation and contaminated site management.

In relation to methodologies, two parallel lines were compared. One of them employ a database able to number and evaluate this sites. The other one is used in case-by-case studies when it is intended to establish an inventory.

The focused regions were initially chosen the elements or goods to be protected. Among the universe of industrial/commercial activities being developed in the area were elected those possessing the greatest contaminating potential. Their activities were considered and those considered the most potentially threatening were selected.

These selected activities, both the still active and closed were: chemicals, metallurgy, automotive service stations, transportation services and all waste disposal sites established within the Billings Basin watershed area. The assets to be protected were the region's soil and water (surface and groundwater). 
For each area preliminary assessment, it was used files existent in the archives of the local environmental agency, as well as field inspections.

The information obtained has been first annexed to a "physical" roster made up of handwritten files and later passed on to personal computer files and properly encoded and classified according to their polluting potential considering the properties of the substances used, contamination sources, contaminant transport, mechanisms and relative risk to be assessed.

The study's costs have been identified as being of two kind: one relating to the preliminary investigation and the second to the exploratory investigation carried out in the priority areas.

This study's propositions may be identified as being of proactive, corrective and preventive kind and relating to suggestions for chances in the State legislation, reuse of abandoned industrial/commercial sites and gasoline station. 


\section{INTRODUÇÃO}

Pode-se afirmar que as atividades econômicas e sociais de uma sociedade são os fatores que promovem as transformações em todos os compartimentos do meio ambiente.

Desde a revolução industrial, todas as atividades humanas de produção passaram por sucessivas transformações e foram marcadas pelo desenvolvimento de novas tecnologias, sendo gerada uma grande diversidade de substâncias para os mais diversos fins. Com a intensificação do emprego desses produtos nos diferentes setores da sociedade, como industrial, agrícola e doméstico, atualmente é possível identificar-se a presença dessas substâncias nos diversos compartimentos do ambiente, mesmo em países não produtores das mesmas.

Os interesses econômicos podem ser definidos como responsáveis diretos pelas transformações e pressões a que os compartimentos ambientais são expostos e neste cenário as atividades industriais e comerciais em uma área, região, município ou estado apresentam-se como as principais fontes dessas transformações. As transformações ou alterações ambientais decorrentes da industrialização e/ou comercialização podem estar ligadas ao modelo de produção escolhido, aos produtos produzidos, à legislação vigente e aos resíduos produzidos nessas atividades. Os efeitos indiretos são: a alteração do modelo de produção (agrícola para o industrial) e o êxodo rural resultando em concentração populacional nos centros industrializados.

A preocupação com as conseqüências sobre o meio ambiente e em especial em relação aos solos e águas subterrâneas, decorrentes dos fatores acima citados, só recentemente têm aumentado. Cada vez mais o solo é considerado como a parte mais importante do meio ambiente, além de ser um recurso limitado, sua utilização no cenário urbano não está restrito só a edificações, está sendo utilizado como receptor de resíduos (área de disposição, estocagem ou processamento de produtos) podendo ser definido como meio indutor de contaminação entre diferentes compartimentos. 
Constituem-se fontes potenciais de contaminação dos solos, toda atividade que manipule ou utilize substâncias consideradas agressivas ao homem e ao meio ambiente, em função de sua toxicidade, persistência e mobilidade.

Desta forma, podem ser incluídas nesta categoria: a atividade industrial, áreas de armazenamento de substâncias químicas, de disposição de resíduos, de mineração e algumas práticas utilizadas na agricultura. Entretanto, não se pode considerar essas atividades como possuidoras de um mesmo potencial poluidor. Em que pesem as características relativas à contaminação do solo, as atividades que têm sido mais freqüentemente associadas à existência de áreas contaminadas são as áreas industriais, as atividades comerciais que efetuam armazenamento de produtos químicos e as áreas que efetuam a disposição e o tratamento de resíduos.

"Vale, entretanto, destacar o elevado potencial poluidor das indústrias desativadas. Estas, por terem sido constituídas em períodos onde ainda eram bastante precárias as técnicas, quando ainda não haviam quaisquer preocupações com a preservação da qualidade ambiental, devem ter causado a contaminação dos solos, em níveis ainda insuficientemente avaliados. Outro aspecto a potencializar o risco inerente à existência dessas antigas indústrias, está relacionado à reutilização dessas áreas. As formas de reutilização podem passar pelo reaproveitamento dos edifícios existentes ou através de sua demolição e reedificação. Em ambos os casos os cuidados com a eliminação das substâncias perigosas não têm sido observados, resultando em permanente risco à saúde da população e a manutenção do comprometimento da qualidade dos solos, quando contaminados" (CUNHA,1997).

A dinâmica da ocupação do território urbano provoca a reocupação e a necessidade de se proceder a revitalização de espaços outrora ocupados por atividades potencialmente contaminadoras à saúde humana, aos solos e águas subterrâneas, esse processo legou espaços que necessitam ter seu uso entendido, avaliado, disciplinado e remediado.

A reutilização de imóveis industriais, segundo SANCHÉZ (1998), pode se dar de diferentes maneiras. As construções podem ser tratadas separadamente dos 
terrenos, demolidas, mantidas em seu estado ou reformadas e os novos usos podem ser os mais variados. O novo uso da totalidade do edifício pode ser industrial, comercial, como depósito ou armazém ou ainda como instalação de lazer.

A necessidade de se proceder à sistematização de ações para se determinar, quantificar e qualificar essas áreas podem ser delineadas como as diretrizes básicas que nortearam as politicas públicas desenvolvidas pelas principais agências ambientais dos países mais industrializados.

Neste estudo duas metodologias são comparadas para se dimensionar os problemas vinculados à áreas contaminadas: a desenvolvida pela Companhia de Tecnologia de Saneamento Ambiental - CETESB, denominada "Gerenciamento de áreas contaminadas" e a outra desenvolvida pela Sociedad Pública Gestión Ambiental IHOBE (Espanha).

O cenário idealizado para a aplicação da metodologia escolhida teve as seguintes premissas: ser um município da Região Metropolitana da Grande São Paulo, possuir toda extensão territorial incluída em área de proteção manancial da bacia hidrográfica Billings e possuir um parque industrial diversificado.

Os objetivos deste estudo podem ser definidos para Identificar as atividades potencialmente contaminadoras do municipio escolhido (industriais, comerciais, postos de serviços automotivos e de disposição de resíduos) e suas áreas potencialmente contaminadas, cadastrá-las, quantificar e qualificar os custos de execução do processo de identificação. 


\section{OBJETIVOS}

Os objetivos do estudo são:

- Implementação de metodologia na identificação de áreas contaminadas em município localizado na bacia hidrográfica Billings e que possua toda sua extensão territorial incluída em Área de Proteção dos Mananciais.

- Execução das etapas do processo de identificação de áreas contaminadas.

- Estimativa de custos do processo de identificação de áreas contaminadas. 


\section{REVISÃO BIBLIOGRÁFICA}

O capítulo de revisão bibliográfica sobre a identifacação de áreas contaminadas será divido em: Conceituação, Amplitude global do tema (aspectos legais), Modelos de gestão, Custos, Instrumentos econômicos e as fontes nacionais e internacionais, de captação de recursos financeiros.

\subsection{Conceituação: áreas contaminadas, reutilização e revitalização de áreas industriais desativadas.}

Para as políticas ambientais, CETESB (1999) afirma que historicamente os compartimentos do meio ambiente têm recebido diferentes pesos, pois o conceito da proteção dos solos foi o último a ser abordado nas políticas ambientais dos países industrializados, bem após os problemas ambientais decorrentes da poluição das águas e da atmosfera terem sido tematizados e tratados. O solo foi considerado por muito tempo, um receptor ilimitado de substâncias nocivas descartáveis como o lixo doméstico e os resíduos industriais, com base no suposto poder tampão e potencial de autodepuração, que leva ao saneamento dos impactos criados. Porém esta capacidade, como comprovado posteriormente, foi superestimada e somente a partir da década de 70 , atenção maior foi direcionada à sua proteção.

Para se desenvolver o exercício conceitual do termo área contaminada, descrito por GLOEDEN (1999) e CETESB (1999), ambos autores basearam-se em terminologias empregadas por diferentes autores de países como Bélgica, Reino Unido, Alemanha e Espanha.

Será adotado neste trabalho o conceito descrito por CETESB (1999), onde o termo área contaminada é definido como local ou terreno onde há comprovadamente poluição ou contaminação, causada pela introdução de quaisquer substâncias ou resíduos que nela tenham sido introduzidos, depositados, acumulados, armazenados, enterrados ou infiltrados de forma planejada, acidental ou até mesmo natural. 
Em áreas contaminadas, os poluentes ou contaminantes (vale ressaltar que para os autores, esses termos como também poluição e contaminação são sinônimos), podem concentrar-se nos diferentes compartimentos do ambiente, por exemplo, no solo, nos sedimentos, nas rochas, nos materiais utilizados para aterrar os terrenos, nas águas subterrâneas, ou de uma forma geral, nas zonas não saturada e saturada dos solos; além de poderem concentrar-se nas paredes, nos pisos e nas estruturas de edificações.

Os contaminantes podem ser transportados a partir destes meios, propagando-se por diferentes vias, como exemplo o ar, o próprio solo, as águas subterrâneas e superficiais, alterando suas características naturais ou qualidades e determinando impactos negativos e/ou riscos sobre os bens a proteger, localizados na própria área ou em seus arredores.

A Política Nacional do Meio Ambiente (Lei 6.938/81), segundo CETESB (1999), considera bens a proteger a saúde e o bem estar da população; a fauna e a flora; a qualidade do solo, das águas e do ar; os interesses de proteção à natureza/paisagem; a ordenação territorial e planejamento regional e urbano e a segurança e a ordem pública.

Para a definição das fontes potenciais de contaminação de solos e águas (superficial e/ou subterrâneas), BOULDING (1995), CETESB (1999), FETTER (1993), GLOEDEN (1999), citam o relatório T4 de 1984 do Escritório Americano de Avaliação de Tecnologia, onde foram agrupados 33 (trinta e três) tipos de fontes de contaminação de águas subterrâneas em seis categorias (vale ressaltar, como destaca CETESB (1999), que as mesmas aplicam-se também a solos), a saber:

- Categoria I: é constituida por fontes projetadas para descarga de substâncias no subsolo, incluindo tanques sépticos e fossas negras (normalmente descarregam efluentes de origem doméstica, vários tipos de compostos orgânicos e inorgânicos), poços de injeção de substâncias perigosas, águas salgadas da exploração de petróleo, aplicação de efluentes municipais ou industriais no solo, lodos, de 
tratamento de água, utilizados como fertilizantes, resíduos oleosos de refinarias ("landfarming"),

- Categoria II: Fontes projetadas para armazenar, tratar e/ou dispor substâncias no solo, como áreas de disposição de resíduos (aterros sanitários e industriais, lixões, botas-fora, etc.); lagoas de armazenamento e tratamento de efluentes industrias; depósitos ou pilhas de resíduos de mineração; tanques de armazenamento de substâncias, aéreos ou subterrâneos,

- Categoria III: Fontes projetadas para reter substancias durante o seu transporte como oleodutos, tubulações para o transporte de esgoto e efluentes industriais; transporte de substâncias químicas, como combustiveis por meio de caminhões e trens,

- Categoria IV: Fontes utilizadas para descarregar substâncias como conseqüência de atividades planejadas, práticas de irrigação (fluxo de retorno), utilização de fertirrigação, aplicação de defensivos agrícolas; percolação de poluentes atmosféricos; mineração e/ou sua drenagem,

- Categoria V: constituída por fontes, que funcionam como um indutor ou induzindo descarga por meio da alteração de fluxo, como por exemplo, poços de produção de petróleo, de água, de monitoração, bem como aqueles que apresentam falhas de construção e projeto,

- Categoria VI: Fontes naturais ou fenômenos naturais associados às atividades humanas, das quais pode-se citar a interação entre águas subterrâneas e superficiais contaminadas, a ocorrência natural de substâncias inorgânicas nas águas subterrâneas e a intrusão de cunha salina.

Quando avaliou os principais processos produtivos SHINELDECKER (1992), estabeleceu um guia para avaliação das principais fontes de contaminação ambiental em relação a produtos produzidos, manipulados e intermediários, resíduos gerados e outros materiais associados ao método produtivo, com o intuito de se estabelecer a 
relação entre contaminantes confirmados e estimados em uma atividade ou processo industrial / comercial).

A fim de quantificar os problemas gerados pela presença de áreas contaminadas, em espaço urbano ou rural, GLOEDEN (1999) citando SÁNCHEZ (1998) aponta que são: a existência de riscos à segurança das pessoas bem como das propriedades, os riscos à saúde pública e dos ecossistemas, restrições ao desenvolvimento urbano e a redução do valor imobiliário das propriedades.

A relação entre a sociedade e a natureza, no sistema capitalista, privilegia os aspectos voltados para a produção de bens, sendo o meio ambiente considerado apenas um recurso e o homem a força de trabalho. A ocupação espacial de uma determinada área, território ou empreendimento, em um dado município é feita de forma desigual, dependendo da ação do capital investido ou a investir (ex: posto de serviço às margens de uma represa) o que determina atividades de impactos ambientais nos diversos cenários que compõe o meio ambiente local.

A formação do espaço brasileiro resultou da intervenção do homem sobre o meio ambiente, em função da disponibilidade de capital, o que determina que certa atividade econômica possa predominar durante um periodo, dependendo de interesses econômicos, embora, do ponto de vista ambiental, outros tipos de atividades pudessem ter sido mais convenientes à ocupação desse espaço.

Ao se analisar historicamente o surgimento de áreas contaminadas no Brasil, é necessário entender como foi o processo de industrializaçao brasileiro, bem como as atividades comerciais a ele atreladas e que são também suas formadoras.

Segundo o IBGE (1990), o processo industrial brasileiro têm suas origens na economia cafeeira, pois sua expansão foi permitida pelo acúmulo de capitais comerciais, provenientes dos lucros obtidos por esta atividade agrícola. Com o advento da Independência, em função da crise do sistema colonial português provocado principalmente, pela decadência do capital mercantil gerada pela Revolução Industrial originada na Inglaterra, têm início o processo industrial apoiado, 
sobretudo na instalação de indústrias téxteis e alimentícias. A atividade industrial concentra-se edificada no eixo Rio-São Paulo, desde o Século XIX e em especial ao longo do rio Paraíba, da rede ferroviária federal, como também nos anos 30 até o presente ao longo da rodovia Presidente Dutra.

No Estado de São Paulo a pressão maior da ocupação é encontrada na cidade de São Paulo e em sua Região Metropolitana. A menor intensidade da atividade industrial, a existência de fontes de água com capacidade de autodepuração e as próprias características dos núcleos urbanos, nessas cidades, fizeram com que os problemas ambientais não fossem levados em consideração na época.

As transformações observadas na dinâmica industrial, principalmente após a revolução industrial, são constantemente sujeitas às alteraçōes de mercado, legais e tecnológicas. Em paralelo, as economias modernas impuseram um enorme aumento no ritmo de consumo de bens e serviços, de modo que as empresas industriais dependem cada vez mais do desenvolvimento de novos produtos seja para manter-se competitivas, seja para expandir-se e aumentar suas partes no mercado (SÁNCHEZ, 1998).

A partir do pós-guerra, a medida que o processo industrial vai se intensificando, há uma gradativa alteração na estrutura industrial paulista, onde passam a ter um maior peso os gêneros industriais que requerem um maior consumo d'água, tais como química, petroquímica, metalúrgica. Inicia-se assim a ocupação desordenada de áreas de mananciais d'água (bacias Billings e Guarapiranga na região sul, Cantareira região norte da cidade de São Paulo e Cubatão na Baixada Santista). Os primeiros sinais de desconcentração industrial, na RMSP têm início nos anos $70 \mathrm{em}$ especial na região do Grande $A B C$, devido às políticas de desenvolvimento regional em outras unidades da federação, pois na década de 50 e 60 houve nessa uma concentração excessiva de mão de obra, consequentemente problemas de logística, sindicais e outros (IBGE, 1990).

A concorrência, segundo SÁNCHEZ (1998), não é só de cidades ou estados, mas pode ser até de país como fator de atração à indústrias, com ofertas de incentivos 
fiscais, destinação de linhas de financiamento, mão de obra qualificada ou mais barata.

Outros fatores que podem influir na transferência de uma indústria são a localização inadequada em relação à malha viária, incompatibilidade de usos do solo em relação ao seu entorno, taxas e impostos, valoração imobiliária e a própria concorrência entre países, estados e municípios com políticas de incentivo distintas.

Em seu Plano Diretor para a Proteção do Solo, o IHOBE - SOCIEDAD PÚBLICA DE GESTIÓN AMBIENTAL (1994), cita que da crise industrial à renovação urbana, cada vez mais se confirma a hipótese de esta tem pouco a ver com as crises cíclicas que se supunham consistir o funcionamento da economia de mercado. Os ciclos econômicos, em grande parte assemelham-se às oscilações periódicas que os sistemas biológicos experimentam (ex: o tamanho de determinada população). De uma forma mais específica o Livro Verde do Meio Ambiente Urbano da Comunidade Européia, definiu como tema prioritário às "zonas industriais abandonadas" e cita a cidade de Bilbao como exemplo de que é necessário encontrar um novo uso para estes locais projetando uma nova função e imagem da cidade.

Os legados da desindustrialização no cenário urbano, segundo o IHOBE (1994), são: contribuem para a desvalorização imobiliária regional; impõem a imagem de deterioração e abandono à região; favorecem o surgimento em suas dependências de lançamentos clandestinos de resíduos; favorecem a ocupação clandestina da edificação e podem representar riscos à saúde da população de entorno e ao meio ambiente.

As indústrias desativadas, segundo CUNHA (1997), provavelmente se incluam entre as fontes de contaminação do solo e águas subterrâneas mais importantes da Região Metropolitana de São Paulo, uma vez que sobre elas já não se exerce qualquer forma de controle ambiental e as restrições à sua reutilização estão associadas às leis de zoneamento urbano, as quais ainda não consideram as questões relativas à poluição ambiental. 
A reutilização de antigas áreas industriais tornam-se cada vez mais freqüentes e os custos de revitalização desses locais estão diretamente relacionados à atividade ali desenvolvida. A contaminação dos diferentes compartimentos ambientais tem levado em um lado o desenvolvimento de ferramentas para compreende-los, qualificá-los, quantificá-los e até a introdução de termos de outras áreas, como o exemplo passivo ambiental, onde o mesmo é empregado, nas ciências contábeis para descrever o acúmulo de danos ambientais que devem ser reparados a fim de que seja mantida a qualidade ambiental de um determinado local, representando um valor monetário necessário para repará-los.

Para BITAR e ORTEGA (1997), a investigação de passivo ambiental compreende o conjunto de atividades voltadas à identificação e a avaliação de todos os problemas ambientais existentes em um empreendimento e que foram gerados no passado, podendo até inviabilizar o negócio. Esse tipo de atividade é conhecida por due diligence sendo utilizada como instrumento de gestão ambiental.

As estimativas dos danos causados aos solos por atividades antrópicas, segundo a EUROPEAN ENVIRONMENT AGENCY - EEA (1999), em áreas com intensa industrialização e urbanização acentuada são responsáveis por perdas irreversiveis, em relação à erosão, a contaminação e a impermeabilização. A deterioração deste recurso é um importante denominador nas regiões central, oeste e norte do continente europeu. Para 12 (doze) países da Comunidade Européia os números estimados são da ordem de que haja um total de 1.500 .000 áreas potencialmente contaminadas, sendo que desse total 300.000 já foram identificadas.

Após a reunificação alemã, SANDEN (1998) relata que os novos empreendimentos industriais nos estados de Mecklenburg-Western Pommerania, Berlin, Brandenburg, Saxony, Anhalt e Thuringia estão sendo locados preferencialmente em áreas limpas, denominadas "greenfields", pois os investidores ditos potenciais têm relutância em aceitar o passivo ambiental de áreas outrora ocupadas.

Estima-se que esse modus operanti consuma 120 ha/dia de solo virgem na República Federal da Alemanha, em empreendimentos como shoppings-centers, moradias e 
outros fins segundo GRIMSKI, DOESTSCH e RÜPKE (1998). Esta disfunção imposta ao solo virgem acaba por acarretar a mudança de suas funções ecológicas originais, os autores propõe o uso, ao invés de solo virgem, de áreas industriais antigas e abandonadas denominadas "brownfields".

O incremento de 4 (quatro) milhões de novas residências no Reino Unido no período de 1991 a 2016 com base em estimativa feita pelo Departamento de Meio Ambiente dentro do programa "Onde iremos morar", mostra que $60 \%$ desse total devam ser erigidas em áreas de reuso, ou que em local onde outrora já tiveram um uso. (SYMS, 1998).

Nos Estados Unidos da América a UNITED STATES ENVIRONMENTAL AGENCY USEPA/Bro (1998), define o termo "brownfield" como locais abandonados, sem utilização ou sub utilizados onde a expansão ou a revitalização possue uma condicionante que atribui a este a condição real ou suspeita de contaminação.

A iniciativa de revitalização econômica "Brownfield" da USEPA/Bro compromisso de ajuda às comunidades em relação à revitalização desses locais, tanto ambientalmente, quanto economicamente, mitigando riscos à saúde da população e restaurando a vitalidade econômica, dos mesmos. Muitas áreas por todo EUA foram usadas com fins industriais ou comerciais, no passado e hoje se encontram abandonadas e muitas dessas contaminadas, por esse motivo, muitos investidores e incorporadores receiam absorver os passivos ambientais que esses locais podem possuir, optando por investimentos em locais limpos, os denominados "greenfields". O resultado tem sido áreas industriais abandonadas, num cenário onde a população é exposta a riscos tanto em relação à saúde, como também a sua segurança, alimentando à comunidade um sentimento de falência e desemprego, passando a impressão que o município ou a área sejam inviáveis economicamente, essas interferem com o aspecto paisagístico, social e ambiental.

O termo "Brownfield", segundo a EPA Treasury Fact Sheet de 1996, pode ser entendido como: "propriedades comerciais ou indústrias abandonadas ou 
contaminadas, menos tóxicas que os sítios Superfund, cuja reutilização é dificultada por problemas reais de contaminação ou percebidos como tais". (SÁNCHÉZ, 1998).

Em INSTITUTE for RESPONSIBLE MANAGEMENT, Inc. - IRM (1996), é demonstrado como um local outrora abandonado e/ou contaminado pode ter um tratamento adequado para que possa obter a revitalização necessária, tornando-o apto às novas ocupações, como parque público e as relações que este local deve possuir como o padrão de remediação requerido (quanta limpeza um parque necessita, o interesse da comunidade e as linhas de financiamento que a comunidade dispõe para esta conversão). Vale ressaltar que os padrões de remediação e os níveis de correção estão intimamente ligados aos usos do solo e o desenho final deste espaço livre (parque), assim um planejamento adequado quanto ao uso e ocupação, dos mesmos se faz necessário para que os contaminantes presentes (no solo, nas águas subterrâneas e nos processos de remediação) não entrem em contato com as pessoas por meio de cuidadoso desenho quando de sua conversão.

Em relação a revitalização de área abandonada o modelo apontado como ideal pela USEPA/Bro ${ }_{c}$, sob titulo "Brownfields Success Stories", foi desenvolvido na cidade de Buffalo, estado de New York - EUA, no período de 1995 a 1997. O bota-fora de uma aciaria, com suspeita de contaminação por metais pesados, óleos lubrificantes e outros contaminantes, foi convertido em uma fazenda produtora de tomate. $\mathrm{O}$ resultado direto foi a geração de 175 postos de trabalho, valorização imobiliária de seu entorno, bem como o retorno publicitário na mídia televisiva e impressa.

\subsubsection{Aspectos legais do tema áreas contaminadas no Brasil}

Segundo CETESB (1999), "no Brasil ainda não existe uma legislação específica para o problema de áreas contaminadas $(A C)$. No entanto, a legislação ambiental oferece uma certa base referindo-se indiretamente a diferentes aspectos do problema de AC. Em geral, as leis ambientais visam a preservação ou recuperação da qualidade ambiental, estabelecendo uma política nacional ou estadual de meio ambiente e diretrizes e normas para o controle de poluição. Há também leis específicas que estabelecem instrumentos ambientais especiais com uma certa relevância para o 
problema de áreas contaminadas (AC) (por exemplo; o parcelamento do solo urbano)". O marco legislativo, quanto à pertinência do tema áreas contaminadas pode ser dividido nas instâncias federal e estadual (Estado de São Paulo).

\subsubsection{Legislação federal}

O tema área contaminada, segundo CETESB (1999), está subentendido quando a Constituição Federal do Brasil de 1988 estabelece os princípios da política nacional do meio ambiente. No capítulo VI ("Do Meio Ambiente"), Artigo 225, onde é colocado o princípio, de que: "Todos têm direito ao meio ambiente ecologicamente equilibrado, bem de uso comum do povo e essencial à sadia qualidade de vida, impondo-se ao Poder Público e à coletividade o dever de defendê-lo e presenvá-lo para as presentes e futuras gerações".

A seguir serão descritas as leis onde o assunto áreas contaminadas, em regime federal está contemplado;

A) Lei $N^{\circ} 6.938 / 81$ - sobre a política nacional do meio ambiente

A Lei Federal 6.938/81, regulamentada pelo Decreto $99.274 / 90$, define a política nacional do meio ambiente, regula a estrutura administrativa de proteção e de planejamento ambiental - o Sistema Nacional do Meio Ambiente (SISNAMA). A Lei introduz alguns instrumentos de planejamento ambiental e determina a responsabilidade / penalidade para casos de poluição.

Art. $2^{\circ}$ - A Politica Nacional de Meio Ambiente tem por objetivo a presenvação, melhoria e recuperação da qualidade ambiental propícia à vida, visando assegurar, no país, condições de desenvolvimento sócio-econômico, aos interesses da segurança nacional e à proteção da dignidade da vida humana, atendidos os seguintes principios: (...)

VIII - recuperação de áreas degradadas;

Art. $4^{\circ}$ - A Politica Nacional do Meio Ambiente visará: (...) 
VII - à implantação, ao poluidor e ao predador, da obrigação de recuperar e/ou indenizar os danos causados (...).

O Artigo $3^{\circ}$, Inciso II, define:

Art. $3^{\circ}$ - Para os fins previstos nesta lei, entende-se por:

II - degradação da sua qualidade, a alteração adversa das características do meio ambiente.

Assim, Áreas Contaminadas devem ser entendidas como áreas degradadas.

De acordo com o Art. 14, IV, § 1, o responsável pela poluição tem o dever de reparar os danos causados por suas atividades, ao meio ambiente ou a terceiros ou ele deve pagar indenização correspondente.

Art. $14, I V, \S 1^{\circ}$ - Sem obstar a aplicação das penalidades previstas neste artigo, é o poluidor obrigado, independentemente da existência de culpa, a indenizar ou reparar os danos causados ao meio ambiente e a terceiros, afetados por sua atividade. (...).

O Art. $6^{\circ}$ estabelece o Sistema Nacional do Meio Ambiente (SISNAMA) e determina a estrutura hierárquica das entidades responsáveis da União, dos Estados e dos Municipios, bem como as funções atribuídas pelo Poder Público. Os Estados devem criar órgãos de controle ambiental, os Órgãos Seccionais, e os Municípios criam as suas entidades responsáveis: os Órgãos Locais. Cabe aos Estados e aos Municípios elaborarem normas e padrões, observando as normas do nivel superior respectivo.

Art. $6^{\circ}, \mathrm{VI}$ - Órgãos Seccionais: os órgãos ou entidades estaduais responsáveis pela execução de programas, projetos e pelo controle e fiscalização de atividades capazes de provocar a degradação ambiental;

VII - Órgãos Locais: os órgãos e entidades municipais responsáveis pelo controle e fiscalização dessas atividades, nas suas respectivas jurisdições 
$\S 1^{\circ}$ - Os Estados, na esfera de suas competências e nas áreas de sua jurisdição, elaborarão normas supletivas e complementares e padrões relacionados com o meio ambiente, observados os que foram estabelecidos pelo CONAMA.

$\S 2^{\circ}$ - Os Municípios, observadas as normas e os padrões federais e estaduais, também poderão elaborar as normas mencionadas no parágrafo anterior.

B) Lei No 6.766/79 - sobre o parcelamento do solo urbano

A Lei Federal 6.766/79 define as competências do Estado e do Municipio sobre a questão do parcelamento do solo. É um instrumento importante na interface de Áreas Contaminadas com o desenvolvimento urbano. A Lei não permite o parcelamento do solo em áreas poluídas.

Art. $3^{\circ}$, Parágrafo único: Não será permitido o parcelamento do solo:

II - em terrenos que tenham sido aterrados com material nocivo à saúde pública, sem que sejam previamente saneados;

$V$ - em áreas onde a poluição impeça condições sanitárias suportáveis, até a sua correção.

A Lei contém regulamentos administrativos para a aprovação de projetos de loteamento e desmembramento (Capitulo V) e para o registro de loteamento e desmembramento (Capitulo VI). Através do Art. 12, a Prefeitura Municipal, em casos específicos o Estado (Art. 13), é responsável pela aprovação.

Através do Art. 18, aprovado o projeto, o loteador deve submetê-lo ao registro imobiliário (no Registro de Imóveis).

Art. 49 regula o recebimento comprovado de intimações e notificações (um mecanismo provavelmente importante na questão de notificação ao proprietário de uma $A S / A C$ e as conseqüências relacionadas com a responsabilidade de remediação).

Art. 49 - As intimações e notificações previstas nesta Lei deverão ser feitas pessoalmente ao intimado ou notificado, que assinará o comprovante do recebimento, 
e poderão igualmente ser promovidas por meio dos Cartórios de Registro de Titulos e Documentos da Comarca (...).

C) Lei $N^{\circ} 9.605 / 98$ (sobre as sanções penais e administrativas derivadas de condutas e atividade lesivas ao meio ambiente).

A Seção IV - A Lei prevê penas de reclusão de até 5 anos na Seção IV (Da Poluição e outros Crimes Ambientais ) conforme mencionado no Art. 54:

Art. 54 - Causar poluição de qualquer natureza em níveis tais que resultem ou possam resultar em danos à saúde humana, ou que provoquem a mortandade de animais ou a destruição significativa da flora.

A omissão da autoridade ambiental na apuração das infrações ambientais está sendo considerado como infração administrativa no Art. 70 .

Art. 70 - Considera-se infração administrativa ambiental, toda ação ou omissão que viole as regras jurídicas de uso, gozo, promoção, proteção e recuperação do meio ambiente.

e colocado sob a pena de co-responsabilidade no $\S 3^{\circ}$ :

$\S 3^{\circ}$ - A autoridade ambiental que tiver conhecimento de infração ambiental é obrigada a promover a sua apuração imediata, mediante processo administrativo próprio, sob a pena de co-responsabilidade.

\subsubsection{Legislação estadual}

Em seguida é descrita a constituição estadual de 1989 O problema de AC não é tratado especificamente. No entanto, a Constituição faz referências ao problema de AC no Capítulo IV, Seções I-IV.Descrita por CETESB (1999); 
"O Art. 193 da Seção I - Do Meio Ambiente - estabelece o objetivo de proteger o meio ambiente mediante um sistema administrativo e define vários aspectos da política ambiental, entre os quais a proteção contra a poluição e degradação:

Art. 193 - O Estado, mediante Lei, criará um sistema de administração da qualidade ambiental, proteção, controle e desenvolvimento do meio ambiente e uso adequado dos recursos naturais, para organizar, coordenar e integrar as ações de órgãos e entidades da administração pública direta e indireta (...) XIV - promover medidas juridicas e administrativas de responsabilização dos causadores de poluição ou de degradação ambiental;

$X X$ - controlar e fiscalizar obras, atividades, processos produtivos e empreendimentos que, direta ou indiretamente, possam causar degradação do meio ambiente, adotando medidas preventivas ou corretivas e aplicando as sanções administrativas pertinentes;

Em Art. 201, a Constituição Estadual prevê a integração administrativa entre os Municípios na questão ambiental:

Art. 201 - O Estado apoiará a formação de consórcios entre os Municípios, objetivando a solução de problemas comuns relativos à proteção ambiental, em particular à preservação dos recursos hídricos e ao uso equilibrado dos recursos naturais.

As leis estaduais que em seu conteúdo, o tema áreas contaminadas, ou cadastro dessas, estão contemplados serão apresentadas a seguir.

A) Lei N ${ }^{0} 997 / 76$ - sobre o controle de poluição

A Lei estadual 997/76 dispõe sobre o controle da poluição ambiental.

Art. $2^{\circ}$ - Considera-se poluição do meio ambiente a presença, o lançamento ou a liberação, nas águas, no ar ou no solo, de toda e qualquer forma de matéria ou energia, com intensidade, em quantidade, de concentração ou com características em desacordo com as que forem estabelecidas em decorrência desta Lei, ou que tornem ou possam tornar as águas, o ar ou solo:

1- impróprios, nocivos ou ofensivos à saúde; 
$1 /$ - inconvenientes ao bem-estar público:

III - danosos aos materiais, à fauna e à flora;

IV - prejudiciais à segurança, ao uso e gozo da propriedade e às atividades normais da comunidade.

Art. $3^{\circ}$ - Fica proibido o lançamento ou liberação de poluentes nas águas, no ar ou no solo.

Parágrafo único - Considera-se poluente toda e qualquer forma de matéria ou energia que, direta ou indiretamente, causa poluição do meio ambiente de que trata o artigo anterior.

Considerando $\mathrm{AC}$ como fonte de poluentes permanente do solo, da água e do ar, a Lei deve ser aplicada exigindo medidas adequadas pelo Poder Executivo autorizado.

Art. $13^{\circ}$ - Fica o Poder Executivo autorizado a determinar medidas de emergência a fim de evitar episódios críticos de poluição ambiental ou impedir sua continuidade (...).

B) Decreto $N^{\circ} 8.468 / 76$ regula a Lei $997 / 76$.

O Título IV é dedicado à poluição do solo:

Art. 51 - Não é permitido depositar, dispor, descarregar, enterrar, infiltrar ou acumular no solo resíduos, em qualquer estado da matéria, (...)

Art. $52^{\circ}$ - O solo somente poderá ser utilizado para destino final de resíduos de qualquer natureza, desde que sua disposição seja feita de forma adequada, estabelecida em projetos específicos de transporte e destino final, ficando vedada a simples descarga ou depósito, seja propriedade pública ou particular.

Art. 56 - O tratamento, quando for o caso, o transporte e a disposição de resíduos de qualquer natureza, de estabelecimentos industriais, comerciais e de 
prestação de serviços, quando não forem de responsabilidade do Município, deverão ser feitos pela própria fonte de poluiçäo. (...)

No Art. $5^{\circ}$ do Titulo I são colocadas as atribuições da Companhia de Tecnologia de Saneamento Ambiental - CETESB - como órgão executivo. Considerando a AC como fator nocivo ao meio ambiente, o Art. $6^{\circ}$ estabelece a base legal para o processo do levantamento e análise de ACs, da avaliação dos riscos (incisos. I, II, III, IX etc.) e faz uma referência à integração do problema no planejamento urbano dos Municípios (inciso.VII):

Art. $6^{\circ}$ - No exercício da competência (...), incluem-se entre as atribuições da CETESB, para controle e presenvação do Meio Ambiente:

1 - estabelecer e executar planos e programas de atividade de prevenção e controle da poluição;

II - efetuar levantamentos, organizar e manter o cadastramento de fontes de poluição;

III - programar e realizar coleta de amostras, exames de laboratórios e análise de resultados, necessários à avaliação da qualidade do referido meio;

VII - estudar e propor aos Municípios, em colaboração com os órgãos competentes do Estado, as normas a serem observadas ou introduzidas nos Planos Diretores urbanos e regionais, no interesse do controle da poluição e da preservação do mencionado meio;

IX - efetuar inspeções em estabelecimentos, instalações e sistemas que causem ou possam causar a emissão de poluentes;

C) Lei № $9.509 / 97$ - politica estadual de meio ambiente.

A Lei dispõe sobre a Política Estadual de Meio Ambiente, seus fins e mecanismos de formulação e aplicação. 
O Artigo $1^{\circ}$, Inciso 1 , dispõe sobre a necessidade de prevenir a degradação e promover a recuperação do meio ambiente degradado:

1- adoção de medidas, nas diferentes áreas de ação pública e junto ao setor privado, para manter e promover o equilibrio ambiental e a melhoria da qualidade ambiental, prevenindo a degradação em todas as suas formas e impedindo ou mitigando impactos ambientais negativos e recuperando o meio ambiente degrada.

O inciso VIII coloca como princípio a informação da população, dando indiretamente uma justificativa para o Cadastro de Áreas Contaminadas a nível estadual e/ou municipal:

VIII - informação da população sobre os niveis de poluição, a qualidade do meio ambiente, as situações de risco de acidentes, a presença de substâncias nocivas e potencialmente nocivas à saúde e ao meio ambiente, nos alimentos, na água, no solo e no ar, bem como o resultado das auditorias a que se refere o inciso VII deste artigo.

O inciso XVII dispõe sobre as responsabilidades do poluidor:

XVII - imposição ao poluidor de penalidades e da obrigação de recuperar e/ou indenizar os danos causados e, ao usuário, da contribuição pela utilização de recursos ambientais com fins econômicos, através de atos administrativos e de ações na justiça, sem prejuizo das demais penalidades previstas em lei, incumbindo, para tanto, os órgãos competentes, da administração direta, indireta e fundacional da obrigação de promover as medidas judiciais para a responsabilização dos causadores da poluição e degradação ambiental, esgotadas as vias administrativas.

O Artigo $2^{\circ}$ estabelece os princípios da Política Estadual, entre outros, a prevenção e recuperação do meio ambiente degradado, a informação da população sobre o nível da poluição e a obrigação do poluidor de recuperar danos causados.

Art. $2^{\circ}$ - A Política Estadual do Meio Ambiente tem por objetivo garantir a todos, da presente e das futuras gerações, o direito ao meio ambiente ecologicamente equilibrado, (...) atendidos especialmente os seguintes princípios: 
1 - adoção de medidas, nas diferentes áreas de ação pública e junto ao setor privado, para manter e promover o equilíbrio ambiental e a melhoria da qualidade ambiental, prevenindo a degradação em todas as suas formas e impedindo ou mitigando impactos ambientais negativos e recuperando o meio ambiente degradado;

VII - informação da população sobre os niveis de poluição, a qualidade do meio ambiente, as situações de risco de acidentes, a presença de substâncias nocivas e potencialmente nocivas à saúde e ao meio ambiente, nos alimentos, na água, no solo, no ar;

XVII - imposição ao poluidor de penalidades e da obrigação de recuperar e/ou indenizar os danos causados e, ao usuário, da contribuição pela utilização de recursos ambientais com fins econômicos, através de atos administrativos e de ações na justiça, sem prejuízo das demais penalidades previstas em lei, incumbindo, para tanto, os órgãos competentes, da administração direta ou indireta da obrigação de promover as medidas judiciais para a responsabilização dos causadores da poluição e degradação ambiental, esgotadas as vias administrativas;

Art. $4^{\circ}$ - A Política Estadual do Meio Ambiente visará:

$V$ - à imposição ao poluidor, da obrigação de recuperar e/ou indenizar os danos causados;

O Capitulo II estabelece o Sistema Estadual de Administração da Qualidade Ambiental - SEAQUA e dá a estrutura administrativa pelo Órgão Central (SMA), pelos Órgãos Executores, Órgãos Setoriais e Órgãos Locais.

D) Lei № 6.134/88.-. preservação dos depósitos naturais de águas subterrâneas.

A Lei dispõe sobre a preservação dos depósitos naturais de águas subterrâneas.

Art. $4^{\circ}$ - As águas subterrâneas deverão ter programa permanente de preservação e conservação, visando ao seu melhor aproveitamento. 
$\S 3^{\circ}$ - Para os efeitos desta Lei, considera-se poluição qualquer alteração das propriedades físicas, químicas e biológicas das águas subterrâneas, que possa ocasionar prejuízo à saúde, à segurança e ao bem-estar das populações.

E) Decreto $N^{\circ} 32.955 / 91$.- que regulamenta a Lei $N^{\circ} 6.134 / 88$.

No Capítulo II, a Seção II trata dos resíduos sólidos, líquidos ou gasosos.

Art. $16^{\circ}$ - Os resíduos, sólidos, líquidos ou gasosos provenientes de quaisquer atividades, somente poderão ser transportados ou lançados se não poluírem águas subterrâneas.

Na Seção III, há regulamentos para projetos de disposições de resíduos no solo, bem como a obrigação de monitoramento pelo empreendedor e a obrigação de remediação em casos de alterações na qualidade da água.

Art. $17^{\circ}-\S 1^{\circ}$ - As áreas onde existirem depósitos de resíduos no solo devem ser dotadas de monitoramento das águas subterrâneas, efetuado pelo responsável pelo empreendimento, a ser executado conforme plano aprovado pela CETESB e que deverá conter:

Art. $17^{\circ}-\S 3^{\circ}$ - Se houver alteração estatisticamente comprovada, em relação aos parâmetros naturais de qualidade da água nos poços a jusante, por ele causada, o responsável pelo empreendimento deverá executar as obras necessárias para a recuperação das águas subterrâneas.

F) Lei $N^{0}$ 9.999/98.-. Altera a Lei $N^{\circ} 9.472$, de 30 de dezembro de 1996, que disciplina o uso de áreas industriais.

A lei destaca o fato de que contaminações existentes em áreas localizadas em zonas de uso predominantemente industrial como crucial para permitir ou não um uso mais nobre, por exemplo o uso residencial. 
- Artigo $1^{\circ}$ - nas Zonas de Uso Predominantemente Industrial - ZUPI, divididas nas subcategorias ZUPI-1 e ZUPI-2, de que tratam os artigos $6^{\circ}, 7^{\circ}$ e $8^{\circ}$ da Lei $n^{\circ}$ 1817, de 27 de outubro de 1978, poderão ser admitidos os usos: residencial, comercial, de prestação de serviços e institucional, quando se tratar de zona que tenha sofrido descaracterização significativa do uso industrial e não haja contaminação da área, mediante parecer técnico do órgão ambiental estadual, desde que o uso pretendido seja permitido pela legislação municipal.

G) Outras normas

As seguintes Leis Estaduais têm uma certa relevância indireta para o problema de $A C$ :

- Lei No 898/75 (com redação dada pela Lei No $3.746 / 83$ e Lei $N^{0} 7.384 / 91$ ) disciplina o uso do solo para a proteção dos mananciais;

Lei $N^{0} 1.817 / 78$ estabelece os objetivos e as diretrizes para o desenvolvimento industrial metropolitano e disciplina o zoneamento industrial, a localização, a classificação e o licenciamento de estabelecimentos industriais na RMSP;

- Lei No 7.663/91 estabelece normas de orientação à Política de Recursos Hídricos, bem como ao Sistema Integrado de Gerenciamento de Recursos Hídricos;

- $\quad$ Lei N ${ }^{0} 7.750 / 92$ dispõe sobre a Política de Saneamento.

\subsection{A amplitude do tema áreas contaminadas.}

O mundo industrializado, segundo: IHOBE (1994), BEAULIEU (1998) e SÁNCHEZ (1998), começou a se conscientizar dos problemas causados pelas áreas contaminadas no final da década de 70 e início da década de 80 , após a ocorrência de "casos espetaculares" como "Love Canal", nos Estados Unidos; "Lekkerkerk" na Holanda; "Ville La Salle" no Canadá, "Gernika" no País Basco. Após estes eventos foram criadas políticas e legislações em vários países, províncias e estados. 
Os cinco tipos de abordagem governamentais que SÁNCHEZ (1998), identificou para lidar com os problemas gerados pelas áreas contaminadas, foram: a negligente, a reativa, a corretiva, a preventiva e a proativa.

A abordagem negligente é observada em países ou regiões onde ainda não existe um reconhecimento público dos problemas gerados pelas áreas contaminadas. Sob a alegação de que a população não se preocupa com estes problemas, não efetuando reclamações, ou alegando a existência de outros problemas mais importantes, como por exemplo, os vários problemas sociais existentes em países em desenvolvimento, o problema das áreas contaminadas na maior parte das vezes é ignorado.

A abordagem reativa caracteriza-se pela adoção de ações emergenciais em situações onde os riscos ou danos são evidentes e existe pressão da população para que os órgãos governamentais tomem alguma atitude.

A abordagem corretiva adota formas planejadas e sistematizadas de ação, prevendose as intervenções necessárias em áreas contaminadas prioritárias. Pressupõe a necessidade de remediar áreas contaminadas após a identificação e diagnóstico destas.

A abordagem preventiva considera que embora os contaminantes possam ter-se acumulado durante a operação de um empreendimento, eles devem ser reduzidos ou eliminados quando de sua desativação ou fechamento. Tal enfoque pressupõe, no mínimo, a preparação e implementação de um plano de desativação do empreendimento.

A abordagem proativa é aquela que busca evitar que a contaminação se acumule durante a operação de um empreendimento, minimizando assim os impactos ambientais durante todo o ciclo de vida de uma instalação.

Segundo SÁNCHEZ (1998), os países que mais avançaram no trato da questão das áreas contaminadas, passando por etapas caracterizadas por posturas negligentes $e$ reativas, evoluiram no sentido de adotar políticas corretivas, e começaram também a 
esboçar ações de cunho preventivo, voltadas para alguns setores industriais/comerciais, cujo potencial de contaminação de solos é elevado.

As políticas e legislações sobre áreas contaminadas, adotadas em países como: Estados Unidos, Holanda e Alemanha, foram descritas por GLOEDEN (1999); a seguir, serão abordadas, de forma suscinta, essas metodologias.

\subsubsection{Estados Unidos da América}

Nos Estados Unidos, na metade da década de 70, os problemas de contaminação do solo, da água e do ar, gerados pelo manejo inadequado de substâncias perigosas foram reconhecidos amplamente. Como conseqüência, o Congresso Americano, em 1976, aprovou a primeira lei relacionada este problema, que foi a Lei de Conservação e Recuperação dos Recursos ("Resource Conservation and Recovery Act" - RCRA), que regulamenta a gestão das substâncias perigosas (tratamento, armazenamento, transporte e disposição final), segundo CASE (1997) citado em GLOEDEN (1999).

"Em seguida, em 1980, visando complementar o RCRA, com enfoque direto sobre os problemas gerados pelas áreas contaminadas abandonadas ou desativadas, e com o objetivo de recuperar a qualidade dos solos contaminados e outros meios atingidos antes que estes causassem prejuizos à saúde humana e ao meio ambiente, foi aprovado pelo Congresso Americano a lei intitulada Lei Ambiental Ampla para Resposta, Compensação e Responsabilização ("Comprehensive Environmental Response, Compensation and Liability Act" - CERCLA)" (LEE, 1997.citado em GLOEDEN, 1999).

Para cumprir o objetivo do CERCLA, segundo CHIRAS (1994) citado em SÁNCHEZ, (1998), foi criado o primeiro fundo nacional para recuperar áreas contaminadas, mais conhecido como "Superfund", para financiar a identificação da áreas contaminadas, a realização de ações emergenciais, a caracterização e recuperação das áreas contaminadas abandonadas ou desativadas, onde não há responsável identificado. Por meio do CERCLA foram destinados, para um período de cinco anos, um bilhão e seiscentos milhöes de dólares a ser aplicado nas áreas abandonadas mais críticas existentes no país. Em 1986 foi promulgada a Lei de Reautorização e Reforma do 
Superfundo ("Superfund Amendments and Reauthorization Act" - SARA), disponibilizando mais US $\$ 8,5$ bilhões, dobrando para US $\$ 16,3$ bilhões quando da nova reautorização em 1990.

Os recursos do "Superfund" são utilizados para garantir que as áreas contaminadas incluídas na Lista Nacional de Prioridades ("National Priority List" - NPL) sejam investigadas e remediadas.

O processo de identificação, investigação e recuperação de áreas contaminadas no CERCLA, segundo GLOEDEN (1999), é constituído pelas seguintes etapas:

A identificação do local e a avaliação inicial, nas áreas com a presença de substâncias perigosas indicadas por relatórios federais, estaduais ou até mesmo por denúncias dos cidadãos. Em seguida as áreas indicadas são registradas no "Comprehensive Environmental Response and Liability System" - CERCLIS, que é o inventário do CERCLA;

Nas áreas registradas no CERCLIS, a USEPA deve realizar uma Avaliação Preliminar, utilizando-se dos dados existentes sobre a área e inspeção ao local.

As informações obtidas são ranqueadas no Sistema de Ranqueamento de Risco (HRS), que utiliza esses dados para se priorizar essas áreas. A área é submetida a um critério de pontuação, que leva em consideração a toxicidade das substâncias, a localização dos receptores, os caminhos de exposição e o risco para a cadeia alimentar humana, para o ar e para as águas subterrâneas.

Segundo a AMERICAN SOCIETY FOR TESTING AND MATERIALS - ASTM (1996), os niveis a serem atingidos, ou os objetivos da remediação de solos e águas subterrâneas contaminadas, têm sido definidos aplicando-se diferentes critérios, desde a aprovação do CERCLA e também do RCRA. Estes critérios são:

- Limpeza da área até os níveis de concentração natural ("background") serem atingidos; 
- Limpeza até níveis estabelecidos pelos limites de detecção;

- Limpeza até níveis não detectados pelos métodos analíticos;

- Limpeza até níveis estabelecidos pela capacidade da melhor tecnologia disponível de remediação;

- Limpeza até niveis estabelecidos por precedentes, por exemplo, registros de decisões em áreas do "Superfund", decisões de autoridades em locais similares;

- Limpeza até niveis de padrões existentes ou guias, por exemplo, Niveis Máximos de Contaminação (MCLs) estabelecidos no "Safe Drinking Water Act", níveis de ação no Regulamento de Ação Corretiva do RCRA, etc.;

- Limpeza até níveis de proteção individual de exposição potencial, como os estabelecidos por estudos de avaliação de risco à saúde;

- Combinação destes critérios.

Nos Estados Unidos outros programas são destinados à remediação de áreas contaminadas, como o próprio "Resource Conservation and Recovery Act" (RCRA), que possue programas de ação corretiva para propriedades industriais ativas, além de vários programas estaduais, que incluem instalações federais do Departamento de Defesa e Energia. Mais de 40 (quarenta) estados possuem seus próprios programas para locais que não estão sendo endereçados pelos esforços federais. A extensão global do problema da remediação de áreas contaminadas nos Estados Unidos é enorme, mesmo que as discussões correntes sobre intervenções expeditas, visando a adequação ao uso do solo ou a realização de remediação tratando-se apenas os locais com concentração mais elevadas de contaminantes ("hot spots"), o custo final para recuperação das áreas cadastradas são estimados em dezenas de bilhões de dólares (KOVALICK; KINGSCOTT apud GLOEDEN, 1999).

\subsubsection{Alemanha}

A primeira Lei de Resíduos Sólidos na Alemanha entrou em vigor em 1972 e definiu pela mudança da responsabilidade dos lixões municipais, passando a responsabilidade aos Distritos. Tanto a Lei atual (Lei de Resíduos Sólidos de 1986), quanto a nova Lei de Circuito Econômico e de Residuos Sólidos, que substituirá a 
primeira e entrou em vigor final do ano 1996, não dispõem de um parágrafo específico de Áreas Contaminadas (AC).

Através da sua estrutura federativa, como afirma CETESB (1999), a Alemanha estabeleceu um sistema jurídico-administrativo de proteção do solo nos três níveis governamentais: federal, estadual e municipal. O problema ambiental de AC é um aspecto integrante da proteção do solo. Desta forma, a recente Lei Federal de Proteção do Solo, contém um item especial sobre AC. Na maioria dos Estados o problema de $A C$ também foi integrado em leis de proteção do solo ou de resíduos sólidos. A nivel local, os municípios alemães não dispõem de leis próprias. Mas, os órgãos locais estão encarregados, principalmente, do gerenciamento de $\mathrm{AC}$.

Um dos problemas centrais do gerenciamento de áreas contaminadas é o de se determinar quando uma área pode ser declarada "suspeita" de contaminação. Assim criou-se a demanda para que houvesse uma normatização em nivel estadual e federal. A elaboração de tais normas foi um processo dificil e demorado, principalmente no nivel federal, por razões técnicas, econômicas, sociais, jurídicas e políticas que dificultaram a regulamentação. A definição dos parâmetros e técnicas válidos para todo o país requereu um longo processo de elaboração, por vários grupos de trabalho, interestaduais e interdisciplinares.

Esta demanda foi respondida pela Regulamentação da Lei de Proteção de Solo e de Áreas Contaminadas ${ }^{1}$ que foi decretada pelo governo federal da Alemanha em Junho 1999 e representa o passo decisivo na regulamentação e normatização de todas as etapas do gerenciamento de áreas contaminadass na Alemanha (CETESB, 1999).

A Lei de Proteção de Solo e de Áreas Contaminadas (Bundes - Bodenschutzgesetz) de 1998 dispõe sobre a atuação do Estado em casos de poluição do solo. Os aspectos principais dizem respeito à modificações das condições física, química e biológica do solo, que podem levar a prejuizos o indivíduo, a sociedade. Sua

\footnotetext{
' Verordnung zur Durchführung des Bundes-Bodenschutzgesetzes (Bodenschutz- und Altlastenverdordnung BBodSchV)
} 
regulamentação, em 1999, traz como instrumento central os critérios para execução de investigação e avaliação de áreas suspeitas de contaminação, valores orientadores e critérios para o controle de qualidade amostral.

A Lei Federal de Recursos Hídricos de 1986 estabeleceu diretrizes para o armazenamento e depósito de substâncias junto a mananciais de águas (superficiais e/ou subterrâneas).

Segundo CETESB (1999), 10 (dez) estados ${ }^{2}$ da federação alemã estabeleceram seções especiais sobre áreas contaminadas. O Estado de Hessen estabeleceu uma legislação própria, denominada: Lei de Áreas Contaminadas (Hessisches Altlastengesetz) de 1994.

Os principais atributos da lei são:

- Definição do objetivo da lei e definição da terminologia;

- Descrição do processo (reconhecimento de uma área suspeita e abertura do processo, identificação, avaliação, análise e remediação);

- Esclarecimento da relação órgão público/proprietário (causador da contaminação);

- Pagamento de custos, reembolso, compensação do valor crescente;

- Elaboração e administração de um Cadastro de AC;

- Declaração de uma área como AC (ato administrativo, registro em cadastros);

- Definição da responsabilidade pela remediação;

- Esclarecimento das competências dos órgãos públicos;

- Multas.

O Estado da Renânia do Norte-Vestfália (NRW) estabeleceu uma seção própria sobre o tema Áreas Contaminadas dentro da Lei Estadual de Resíduos Sólidos de 1995. Os enfoques legislativos são:

- Os procedimentos de identificação, avaliação, remediação e monitoramento,

\footnotetext{
${ }^{2}$ Nordrhein-Westfalen, Baden-Würthemberg, Niedersachsen, Bayern, Rheinland-Pfalz, Thüringen, Sachsen-Anhalt, Brandenburg, Mecklenburg-Vorpommern, Saarland
} 
- Responsabilidades,

- Elaboração/administração de um cadastro,

- Competências,

- Regulamentos para transferência de dados e pesquisas básicas.

\subsubsection{Holanda}

Na Holanda, segundo IHOBE (1994), a Lei Provisória para a Limpeza dos Solos, de 1983, e a Lei para a Proteção do Solo, de 1987, regulamentam as medidas necessárias à prevenção da contaminação do solo e a adoção de medidas para a remediação de solos contaminados.

O conceito central da política holandesa é a restauração das propriedades funcionais do solo para o homem, flora e fauna (conceito da "multifuncionalidade"), isto é, implica que o objetivo da remediação, em longo prazo, é atingir as concentrações naturais.

$\mathrm{Na}$ legislaçăo holandesa é dado grande destaque para as medidas preventivas, que se baseiam nas licenças ambientais exigidas pelos órgãos provinciais e municipais para vários tipos de atividades industriais. Um novo guia para o estabelecimento de tecnologias e medidas para a prevenção da contaminação do solo estão sendo desenvolvidas para auxiliar na aplicação das licenças, visando orientar a execução do projeto das novas instalações. Assim, espera-se o melhorar as condições dos pisos, pavimentos, sistemas de coberturas, transporte de efluentes, tubulações em geral, monitoramento da qualidade dos solos e das águas subterrâneas e avaliação de riscos potenciais.

A base para o planejamento e adoção de medidas corretivas é a utilização dos sistemas de gerenciamento em regiões geográficas específicas, isto é, nas províncias e municípios. As informações obtidas a partir dos procedimentos estabelecidos para o gerenciamento são utilizadas para: 
- Informar o público e empresas sobre a qualidade do solo e as restrição ao seu uso, como por exemplo, passivos ambientais prejudiciais ao processo de transferência de propriedades;

- Dar suporte ao planejamento e desenvolvimento das regiōes, visando garantir o uso sustentável do solo de uma forma aceitável pela sociedade;

- Estabelecer prioridades para a adoção de medidas corretivas em áreas contaminadas;

- Estabelecer procedimentos para conceder licenças para construções, considerando as necessidades de remediação dos solos contaminados;

- Prevenir a contaminação de solos limpos.

Os conhecimentos ou informações adquiridas são registrados em inventários visando, por exemplo, confeccionar mapas dos locais identificados e investigados, da qualidade do solo e de vulnerabilidade, que são a base para a tomada das decisões relativas à adoção de medidas corretivas em áreas prioritárias.

Em função de problemas técnicos e econômicos, nem sempre é possivel atingir as concentrações naturais em curto prazo requerendo-se, por exemplo, que os contaminantes sejam isolados e imobilizados. Neste caso as propriedades multifuncionais não são restauradas.

Os custos da aplicação das medidas preventivos e corretivos são pagos pela pessoa que realiza o ato de poluir. $O$ poluidor, o proprietário ou o usuário são as partes que podem ser indicadas como responsáveis primários pela contaminação. O governo pode ser indicado nos casos onde não pode ser identificado o responsável pela contaminação.

O governo provincial ou municipal avalia as propostas de remediação e negocia as soluções caso a caso, de acordo com critérios estabelecidos na legislação e pelas autoridades. Durante a remediação o governo atua como fiscal dos trabalhos de remediação. 
Outros agentes ser envolvidos no processo, desenvolvendo projetos para o reaproveitamento de áreas contaminadas, assumindo os custos de remediação, que poderão ser cobrados posteriormente do poluidor. Existem dois tipos de valores padrão para solo e águas subterrâneas na Holanda: os valores alvo ("target value") e os valores de intervenção. Estes valores substituíram os valores conhecidos anteriormente como valores $A B C$.

Os valores alvo indicam as concentrações a serem atingidas, como objetivo da remediação.

Os valores de intervenção indicam o nivel acima do qual uma contaminação pode ser considerada grave. Eles são os sucessores dos antigos valores $\mathrm{C}$. Se estes valores são ultrapassados em uma área, deverá ser determinada a urgência da implantação das medidas corretivas.

De acordo com a Lei de Proteção do Solo da Holanda, em seu Plano da Política Ambiental Nacional 2, foi estabelecido que a presente geração não deve deixar como herança nenhum passivo ambiental significativo.

Desta forma, os passivos ambientais atuais devem ser reduzidos ou eliminados para proporções aceitáveis até 2015, quando os casos denominados urgentes de contaminação deverão ter sido remediados ou controlados, além de terem sido implantadas medidas de controle nos casos não urgentes de contaminação.

Desde 1 de janeiro de 1995, um sistema foi colocado em funcionamento na Holanda para estabelecimento da urgência de remediação. O sistema é baseado no risco atual para o homem e ecossistemas, além do risco relacionado ao avanço da contaminação.

\subsection{Modelos de gestão que podem estar relacionados às áreas contaminadas.}

Na auditoria ambiental, que é uma forma de gestão, com ênfase na contaminação do solo e água subterrânea, para LAGREGA (1994), é usualmente conduzida em uma 
fase de aproximação, focada em práticas históricas da área enfocada, como: uso químico passado, particularmente substâncias perigosas, matérias primas, como estas são manipuladas e estocadas;

- Passado do gerenciamento de efluentes e práticas de disposição,

- Derramamentos, acidentes que causaram poluição e vazamentos ocorridos,

- Tanques enterrados,

- Lagoas,

- Campos de infiltração e

- Antigos encanamentos de águas servidas e material envolvido na edificação.

As formas de gestão de áreas contaminadas diferem no aspecto político, cultural, nas definições de padrões de solo, nos critérios de avaliação tanto de valoração espacial na malha urbana como nos valores ecológicos a ela imputados, como as interferências antrópicas, o tipo de solo, o tipo de aqǘfero, a qualidade da água subterrânea e seu valor para com a paisagem urbana. (VAN DEN BRINK et al., 1995).

Contudo BUTLER (1996) afirma, baseado em um questionário desenvolvido no âmbito do Programa Ambiental das Nações Unidas - Indústria e Meio Ambiente UNEP/IE, que $75 \%$ (setenta e cinco por cento) dos países que o responderam, possuem em suas legislações abordagens técnico-legislativas onde a temática das áreas contaminadas é contemplada, mas não possuem uma forma gerencial para promover sua quantificação e qualificação.

Para BITAR e ORTEGA (1997), os instrumentos de gestão ambiental constituem-se na sistematização de procedimentos técnicos e administrativos que visam assegurar a melhoria em relação ao desempenho ambiental de um empreendimento ou de uma área a ser protegida. O termo gerenciamento ambiental tem sido empregado ao invés de gestão quando se relaciona à escala territorial a que se está referindo.

Como estratégia corretiva a ser adotada no estado de São Paulo, CETESB (1999), propõe o gerenciamento de áreas contaminadas (ACs) que visa minimizar os riscos a que estão sujeitos a população e o meio ambiente, em virtude da existência das mesmas, por meio de um conjunto de medidas que assegurem o conhecimento das 
características dessas áreas e dos impactos por elas causados, proporcionando os instrumentos necessários à tomada de decisão quanto às formas de intervenção mais adequadas. Com o objetivo de otimizar recursos técnicos e econômicos, a metodologia utilizada no gerenciamento de ACs baseia-se em uma estratégia constituída por etapas seqüenciais, em que a informação obtida em cada etapa é a base para a execução da etapa posterior.

A metodologia de gerenciamento de áreas contaminadas foi aplicada por GLOEDEN (1999), na bacia do reservatório Guarapiranga, onde foram avaliadas preliminarmente:

- Áreas de disposição de resíduos;

- Indústrias químicas;

- Postos de serviço automotivo e

- Outras fontes (cemitério).

Obtendo os seguintes resultados: 36 áreas potencialmente contaminadas (avaliadas preliminarmente), 72 áreas suspeitas de contaminação ( 9 áreas de disposição de resíduos, 13 indústrias quimicas e 50 postos de serviço) e cinco áreas contaminadas (4 postos de serviço e uma indústria química).

Outro modelo de gestão ambiental que pode ser elencado é o denominado P2 Prevenção a Poluição, desenvolvido pela EPA em 1992, com o objetivo de reduzir a quantidade de qualquer substância perigosa ou não, dos poluentes ou dos contaminantes "entrantes" em qualquer fluxo de resíduo ou liberados no meio ambiente de outra maneira, incluindo emissões fugidias; que reduzam os riscos à saúde humana e ao meio ambiente associados com a liberação de tais substâncias, poluentes ou contaminantes; incluam modificações nos equipamentos ou tecnologias, nos processos e procedimentos.

\subsection{Os custos vinculados às áreas contaminadas}


Praticamente toda decisão implica um custo, já que ao escolher uma opção estamos deixando de lado muitas outras. (TROSTER; MOCHÓN, 1994).

O problema na avaliação financeira e os custos envolvidos no setor de áreas contaminadas sofrem pressões externas, quer seja em relação a sua ocupação e as restrições quanto ao seu uso, quer seja em relação às avaliações recorrentes como as do setor imobiliário, as das ações de remediação e seus valores, bem como a sistemática de cadastro e as análises de risco requeridas pelos órgãos de controle. Os custos a serem considerados, podem ser assim divididos; limitação da ocupação de áreas pelo fato de serem contaminadas (custo de desvio); custos pela restrição do uso das áreas de lixões e aterros sanitários fechados (áreas de disposição de lixo) e de ACs recuperadas (custo de prejuizo); Identificação, avaliação do risco e controle da AC (custos de planejamento e controle) remediação das ACs (custos de remediação). Para exemplificar o cálculo de custos preventivos, conforme as especificações e a localidade de uma dada área, foi desenvolvido pelo Ministério Federal de Meio Ambiente Alemão - BMU o KOSAL, que é uma sistemática para o levantamento de custos para a remediação de áreas contaminadas. A sistemática é composta por quatro módulos de serviços a serem executados em uma dada área contaminada e o valor percentual da atividade no custo total do projeto de remediação adotado.

Para TROSTER; MOCHÓN (1994), os custos são importantes, pois ajudam a selecionar as melhores decisões para se ajustar aos objetivos.

Em KYAS; JAGGY (1998) a visão do banqueiro e a de um engenheiro são focadas sobre o assunto custo $x$ benefício, tanto em relaçäo da remediação de áreas como em um cadastro de áreas contaminadas, demonstram que na Suiça os procedimentos genéricos em um dado gerenciamento de áreas contaminadas, são divididos em quatro etapas e cada uma dessas carrega consigo um valor agregado (VA). As etapas são divididas em:

- Identificação da área $>(V A)>$ Perda de valor da propriedade,

- Investigação Preliminar > Área Contaminada (VA) > Perda de valor, custos de Investigação Preliminar, 
- Investigação Detalhada > Alvos de Remediação (VA) > Perda de Valor, Custos da Investigação Detalhada,

- Remediação > (VA) > Perda de Valor, Custos para Remediação, ...

O custo para o desenvolvimento de um projeto de remediação de uma área contaminada, segundo LAGREGA (1994), é dividido basicamente em dois tipos, ou categorias, à saber; o custo de capital (custo para construção e remediação) e o custo de operação anual, manutenção e mão de obra envolvida ( $O$ \& $M$ ). O valor do custo de avaliação de alternativas, para remediaçăo de áreas contaminadas, depende basicamente de orientação particular (consultorias) ou de agências envolvidas no esforço de regulamentação das mesmas

Para o COMPASS (1997), os custos são avaliados através de contabilidades já executadas e os inclui nas avaliações financeiras, identificando-os, como:

- Custos Diretos ou Convencionais; incluem os custos que são usualmente identificados em análises financeiras convencionais (ex: matérias primas,...),

- Custos Indiretos; são aqueles que não são alocados para produtos individuais, processos e facilidades (ex: desenho, regularização,...),

- Custos de Contingência; são aqueles que não podem ser identificados durante o projeto de avaliação,

- Custos de Baixa Quantificação; são aqueles que requerem muitas interpretações para avaliá-los e quantificá-los (ex: imagem da empresa ou corporação,...).

Como ressalta NEWMOA (1998), a parte mais importante na análise financeira para prevenção de poluição é a identificação e a coleção de todos os custos relevantes. A primeira fase da análise financeira de um projeto de prevenção à poluição requer uma união completa e acurada de dados sobre os custos denominados de incremento e os relevantes calculados em bases anuais, como definidos abaixo:

- Custos de Incremento; são as diferenças ou mudanças entre os custos de processos em andamento e aqueles que o novo projeto propöe. Estes custos, inicialmente, gastos com compra e instalação de equipamentos e despesas de 
operação, como matérias-primas, manutenção, disposição de resíduos e utilidades em contínuo com a vida útil do projeto,

- Custos Relevantes; são aqueles custos de incremento que têm um impacto material na análise e naqueles que são usados para composição dos mesmos, cujas propostas de projeto são avaliadas. O teste para relevância depende de circunstâncias particulares e são considerados no contexto de um determinado projeto.

Para o entendimento e a identificação de custos denominados diretos e indiretos o COMPASS (1997), determina que os investimentos necessariamente devem ser avaliados através de um inventário que inclua os custos de capital e os custos operacionais.

Os passos para o desenvolvimento de informações na obtenção de custo, segundo NEWMOA (1998), entre processos existentes e novos, são baseados no desenho de fluxo de processos já existente, novos e/ou modificações.

Na ótica do IHOBE (1994), o processo para a estimativa de custos de remediação do passivo ambiental é dividido em três segmentos, que são:

- Estimativa do esforço e gastos que em forma de estudos e investigações se devem realizar, a fim do entendimento da extensão do problema, a definição do grau de urgência (bens a proteger, risco a saúde humana,

- Estimativa de custo na remediação de áreas a médio prazo, como escavações seletivas, transporte adequado do material escavado, isolamento do perímetro, etc...,

- Estimativa de custos correspondentes às operações de eliminação total do problema, que em geral são aquelas que são abordadas a longo prazo.

Para o IHOBE (1994), os custos unitários das atividades de investigação, escavação, controle ou destinação dos residuos e os tratamentos a que são submetidos os solos e águas contaminadas, são calculados com as informações disponíveis no programa SITE da USEPA, as estimativas publicadas pelo Plano de Solos Contaminados da 
Holanda, os casos práticos compilados nas Conferências KfK-TNO, dados de empreiteiras e de empresas de consultorias.

Quando se efetua as etapas de avaliação preliminar, investigações analíticas e se descreve o processo de obtenção de dados, HOFFMAN (1987), sugere que há a necessidade de se estabelecer o binômio denominado, tempo e recursos financeiros. Pode-se usar para essa esquematização o gráfico de Gantt ou o "Program Evaluation and Review Technique - PERT", ou a técnica de avaliação e revisão de programas denominado técnica do caminho critico.

Segundo HOFFMAN (1987), o gráfico de Gantt é utilizado para a distribuição de trabalhos, onde uma dada tarefa é representada graficamente por uma tabela onde são listados os fatores de produção bem como seus respectivos trabalhos e o tempo disponivel aos fatores de produção. Com uma simbologia padronizada demarca-se ao longo do periodo um segmento proporcional ao intervalo de tempo necessário para a execução de cada tarefa.

Quando avaliou a implantação de análise de risco ambiental em uma siderúrgica, PEREIRA (1998), estimou o custo da implantação de análise de risco ambiental, baseando-se no binômio: hora consumida por homem envolvido para realização da tarefa, ou seja foram estimadas as horas / homem consumidas para cada para cada uma das unidades de produção.

\subsection{Instrumentos econômicos vinculados ao gerenciamento de áreas contaminadas e as fontes de captação de recursos financeiros.}

"Os instrumentos econômicos, no cenário ambiental, são formas de incentivo financeiro para que se desenvolva uma série de medidas preventivas nas fontes de geração de poluentes. O objetivo da aplicação desses é tornar medidas regulamentadoras desnecessárias. Como exemplo, a aplicação de tarifas mais elevadas para cada tonelada de resíduo perigoso gerado de uma dada atividade estimularia a diminuição da geração da mesma" (CETESB, 1999). 
Em sintese, esses estabelecem um indutor às linhas de financiamento cabendo ao agente gestor do futuro gerenciamento e/ou revitalização de áreas contaminadas a forma de obtenção e os meios de captação das linhas de recursos.

Segundo CETESB (1999), a amplitude dos instrumentos econômicos na esfera ambiental podem estar relacionados às atividades de fomento $e$ as subvenções governamentais, como os incentivos fiscais.

A proposição de outorgas de cotas de poluição à indústrias como forma de gestão de recursos hídricos, segundo CAETANO (1999), seria uma das formas de gestão aplicada de instrumento econômico que um município ou comitê de uma bacia hidrográfica podem dispor. Segundo o autor cada indústria localizada em uma determinada bacia hidrográfica só pode despejar seus efluentes nessa, segundo o binômio: quantidade de contaminante $x$ título de contaminante de que esta dispõe.

Segue uma coletânea de dados e informações gerais sobre instrumentos econômicos, agentes financeiros, custos especificados e modelos de financiamento aplicados, tanto em projetos de remediação, como em gerenciamento e/ou revitalização de áreas contaminadas.

\subsubsection{Fontes Nacionais e Internacionais de Cooperação Financeira}

\subsubsection{Fontes Nacionais}

Segundo SPSMA (1996), as fontes nacionais de cooperação financeira, são entidades de financiamento de origem pública como bancos de desenvolvimento e fomento (Banco Nacional de Desenvolvimento Econômico e Social (BNDES) e a Caixa Econômica Federal (CEF)) e também de origem privada como o UNIBANCO.

\section{Caixa Econômica Federal (CEF)}

Programa Pró - Saneamento 
A CEF através do Decreto Lei 1.522 de 13/07/95, conferido pela Lei 8.036 de 11/05/90, utiliza recursos do Fundo de Garantia do Tempo de Serviço (FGTS) para este programa. As principais modalidades do Pró - Saneamento são:

- Resíduos Sólidos: Modalidade que se destina ao financiamento de obras para ampliação dos serviços referentes ao tratamento, disposição adequada de resíduos sólidos quer seja em empreendimentos (Usinas de triagem, compostagem), aterros sanitários novos, lixões e bio - remediação.

- Estudos e projetos: Modalidade que se destina à elaboração de estudos e projetos, para empreendimentos nas modalidades de abastecimento de água, esgotamento sanitário, drenagem urbana e resíduos sólidos.

\section{CLIENTELA}

Os recursos do Programa Pró-Saneamento podem ser obtidos por: Estados, Municípios e Distrito Federal; concessionárias estaduais e municipais de saneamento; órgãos autônomos municipais do setor.

\section{ÁREA DE ATUAÇÃO}

A área de atuação do Programa Pró-Saneamento é de âmbito nacional, com diferenças de contrapartida (\% do valor do investimento) e juros conforme a região do Brasil o qual está sendo solicitado.

\section{Ministério do Planejamento e Orçamento (MPO)}

Secretaria de Política Urbana

Caixa Econômica Federal (CEF)

Programa de Ação Social em Saneamento

O Programa de Ação Social em Saneamento têm por objetivo a melhoria das condições ambientais e saúde das populações, dos municípios que compõe o programa.

\section{OBJETO DO FINANCIAMENTO}

O objeto do financiamento é o de fomentar duas linhas básicas, à saber: 
Serviços de esgotamento sanitário e abastecimento de água ou Implantação, ampliação e/ou melhoria dos serviços de tratamento e coleta de resíduos sólidos.

\section{Banco Nacional de Desenvolvimento Econômico e Social (BNDES).}

O BNDES, órgão vinculado ao Ministério do Planejamento, é o principal instrumento do governo federal para os financiamentos a longo prazo, que tenham por objetivo promover o desenvolvimento do país.

O sistema BNDES é formado pelas subsidiárias, Agência Especial de Financiamento Industrial (FINAME) e o BNDES Participações S/A (BNDESPAR), ambas com o objetivo de prestar colaboração financeira para com as empresas sediadas no Brasil, cujos projetos sejam considerados prioritários no que se denomina - Políticas Operacionais do Sistema BNDES.

\section{Ministério do Meio Ambiente, dos Recursos Hídricos e da Amazônia Legal (MMA).}

Fundo Nacional do Meio Ambiente - FNMA

O Fundo Nacional do Meio Ambiente tem como objetivo apoiar projetos que visem a conservação, recuperação e o uso sustentável dos recursos naturais, contribuindo para a melhoria da qualidade de vida, bem como a promoção da participação da sociedade civil na solução dos problemas ambientais no país.

\section{CLIENTELA}

A clientela que o fundo objetiva são as entidades públicas (das diversas esferas governamentais), Organizações Não Governamentais atuantes na área ambiental, Associações, Cooperativas de produtos, Federações e Sindicatos. 


\section{Fundo Estadual de Recursos Hídricos - FEHIDRO \\ Conselho de Orientação do Fundo Estadual de Recursos Hídricos - COFEHIDRO}

O Fundo Estadual de Recursos Hídricos - FEHIDRO, segundo o Manual de Procedimentos Operacionais de outubro de 1998 , foi criado pela Lei $n^{\circ} 7.663 / 91$ e regulamentado pelos Decretos 37.300/93 e 43.204/98, com o objetivo de dar suporte financeiro à Política Estadual de Recursos Hídricos e às ações correspondentes.

\section{CLIENTELA}

Poderão habilitar-se à obtenção de recursos do FEHIDRO :

Pessoas jurídicas de direito público, da administração direta ou indireta do Estado e dos Municípios; concessionários de serviços públicos, nos campos de saneamento, meio ambiente e de aproveitamento múltiplo de recursos hídricos; pessoas jurídicas de direito privado usuárias de recursos hídricos; consórcios intermunicipais regularmente constituídos.

A concessão de financiamentos, reembolsáveis ou não, dependerá de parecer favorável dos agentes técnicos quanto à viabilidade técnica, econômico-financeira e jurídica. No caso de financiamento No caso de financiamentos reembolsáveis dependerá, ainda, de aprovação, pelo agente financeiro, da capacidade creditória do requerente e das garantias a serem oferecidas.

\section{UNIBANCO Ecologia}

Em SPSMA (1997), consta como o único banco comercial com atuação efetiva pró meio ambiente em atividade desde o ano de 1991. Sua finalidade principal é de prover o apoio à projetos de preservação ambiental e a methoria da qualidade de vida da comunidade como co-patrocinador desses sob a ótica de cooperação financeira a fundo perdido.

\section{CLIENTELA}

A clientela desta instituição são as Organizações Não Governamentais (ONGs), Clubes de Serviço (Rotary Club, Lions Club, etc...), Universidades e parcerias com a 
iniciativa privada em patrocínio a projetos comunitários. No caso de Prefeituras as mesmas podem participar através de parcerias com uma das entidades citadas anteriormente.

\subsubsection{Fontes Internacionais de Cooperação Financeira}

Os municipios e entidades públicas podem requisitar empréstimos para execução de projetos (como o gerenciamento de áreas contaminadas), junto a fontes internacionais de cooperação financeira, através da intermediação da Comissão de Financiamentos Externos do Ministério do Planejamento (COFIEX). Esta comissão têm a atribuição, na pertinência do tema, de avaliar as condições do proponente para contrair o empréstimo, qualidade e exequibilidade do executor bem como o projeto.

Nos projetos direcionados à área ambiental, a COFIEX tem como diretriz atender o pedido de financiamento, preferencialmente, sob a forma de doação. O acesso a essa comissão se faz por intermédio da Secretaria de Assuntos Internacionais (SEAIN) que acumula a atribuição da Secretaria Executiva da Comissão.

\section{Banco Mundial}

O Banco Mundial é composto pelo Banco Internacional de Reconstrução e Desenvolvimento (BIRD) e a Corporação Financeira Internacional (CFI), sendo que o seu principal papel é o de financiar os projetos de desenvolvimento na melhora da qualidade de vida de seus países membros, como também da melhora da gestão ambiental.

\section{CLIENTELA:}

Sua principal clientela são os poderes federal (união), estados e municípios dos países membros. Eventualmente financia empresas de pequeno e médio porte, através da $\mathrm{CFI}$. 


\section{Programa das Nações Unidas para o Desenvolvimento (PNUD)}

O PNUD é um órgão da Organização das Nações Unidas (ONU) que têm por objetivo a melhoria da qualidade de vida, humana e ambiental.

Segundo SPSMA (1997a), o PNUD é a mais importante fonte de cooperação multilateral do mundo e para esse o século 21 exige um novo caminho para a produção, baseada em tecnologia limpa e na reciclagem.

\section{CLIENTELA:}

A clientela que o PNUD objetiva são as instituições governamentais, de ensino e pesquisa.

\section{Banco Interamericano de Desenvolvimento (BID)}

Sua finalidade é cooperar com os países membros, na orientação de suas políticas de desenvolvimento e proporcionar cooperação técnica para elaborar o financiamento $e$ a execução de planos e projetos de desenvolvimento (SPSMA, 1997).

\section{CLIENTELA:}

A clientela que O BID, objetiva são a União, os estados e os municípios. Para empresas, de pequeno e médio porte, essas devem estar coligadas com a Corporação Interamericana de Investimento - Cll. 


\section{METODOLOGIAS}

Neste capítulo serão demonstradas, sucintamente, duas metodologias de gerenciamento de áreas contaminadas e seus processos de identificação. A primeira a ser descrita será a adotada por CETESB (1999), denominada O Gerenciamento de Áreas Contaminadas e a segunda metodologia, para solos contaminados a ser descrita será o Plano Diretor para a Proteção do Solo (1998), que está em curso na Espanha mais precisamente na Comunidade Autônoma do País Basco.

\subsection{O Gerenciamento de Áreas Contaminadas - Companhia de Tecnologia de Saneamento Ambiental - CETESB.}

A metodologia do gerenciamento de áreas contaminadas, desenvolvida por GLOEDEN (1999) e CETESB (1999), baseia-se em uma estratégia constituída por etapas seqüenciais, onde a informação obtida em cada etapa é a base para a execução da etapa seguinte.

Para o desenvolvimento do método, as ações foram divididas em dois processos, que constituem a base do gerenciamento de áreas contaminadas: o processo de identificação e o processo de recuperação de áreas contaminadas.

O processo de identificação de áreas contaminadas, tem como objetivo principal a localização das áreas contaminadas, potencialmente contaminadas e suspeitas de contaminação em uma dada área. É subdividido em quatro etapas:

- Definição da região de interesse,

- Identificação de áreas potencialmente contaminadas,

- Avaliação preliminar e

- Investigação confirmatória.

O processo de recuperação de áreas contaminadas, tem como objetivo possibilitar - planejamento das medidas corretivas a serem adotadas nessas áreas, e é subdividido em seis etapas: 
- Investigação detalhada,

- Avaliação de risco,

- Investigação para remediação,

- Projeto de remediação,

- Remediação e

- Monitoramento.

A compilação das informações coletadas, de uma determinada área ou de uma região, durante a execução das etapas do gerenciamento de áreas contaminadas é registrada em um banco de dados denominado: cadastro de áreas contaminadas (figura 4.1). 


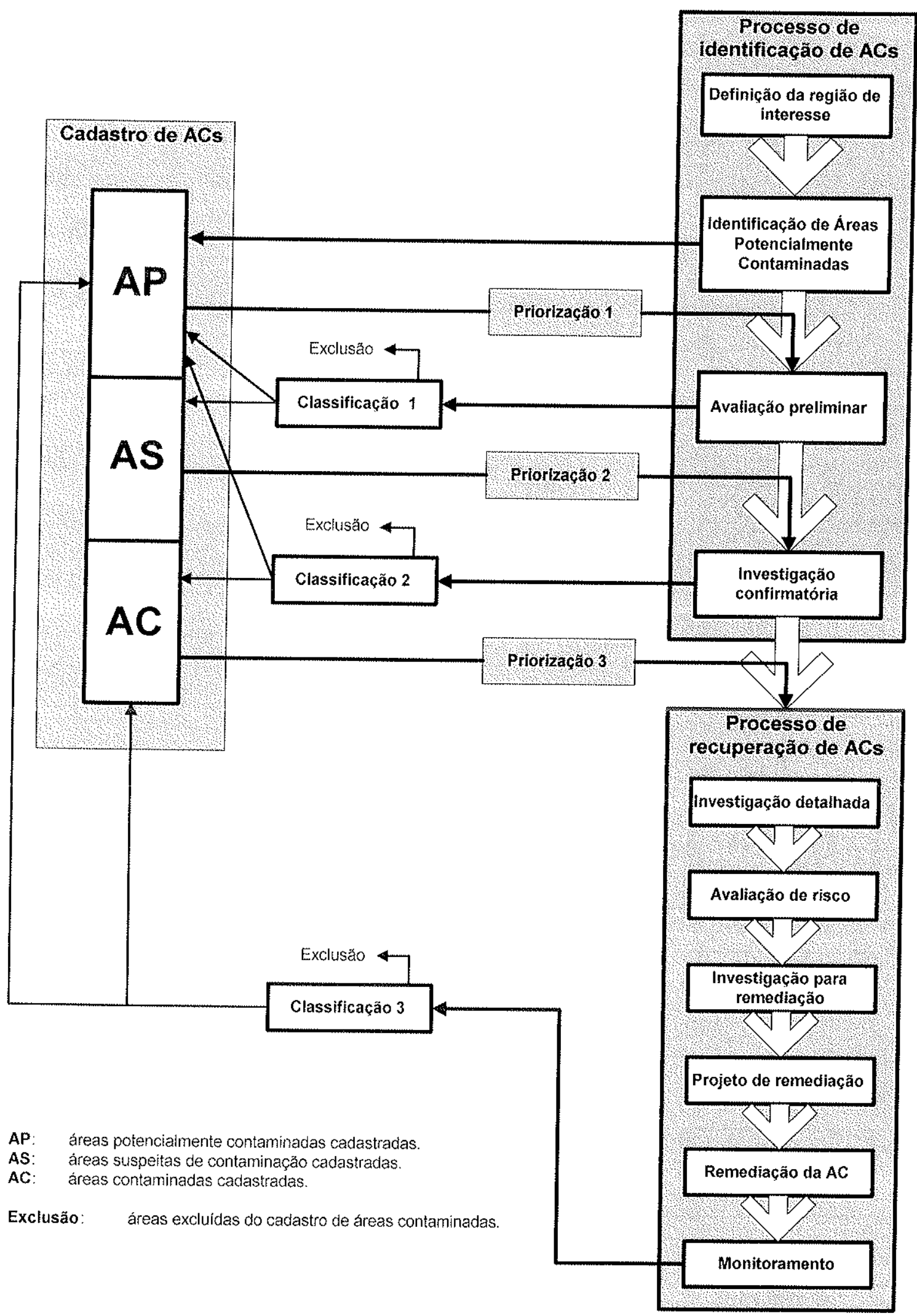

Fonte: CETESB, 1999

Figura 4.1 Fluxograma das etapas do gerenciamento de áreas contaminadas 
Como regra básica da metodologia do gerenciamento de áreas contaminadas, segundo GLOEDEN (1999), todas as informações obtidas, em cada uma de suas etapas, devem ser armazenadas em um cadastro, que além de utilizado como fonte de dados para o planejamento de medidas corretivas nas áreas contaminadas, poderá ser utilizado no controle e planejamento ambiental da região de interesse ou mesmo fornecido para outras instituições públicas ou privadas, para diversos usos, tais como o planejamento urbano e para a elaboração de propostas de ações preventivas e proativas.

A metodologia do gerenciamento de áreas contaminadas desenvolvida por GLOEDEN (1999) foi utilizada como base para a definição dos procedimentos de atuação em áreas contaminadas da CETESB, aprovados no inicio do ano 2000. Dessa forma, as ações desse órgão em relação às áreas contaminadas deverão ser conduzidas de acordo com esses procedimentos.

\subsubsection{O processo de identificação de áreas contaminadas}

Neste estudo somente o processo de identificação de áreas contaminadas será aplicado e a seguir todas as etapas que o compõe serão descritas.

\subsubsection{A definição da região de interesse.}

Podemos definir a etapa "definição da região de interesse" como sendo aquela que deflagra o processo de identificação de áreas contaminadas ou o gerenciamento de áreas contaminadas. Nessa etapa são definidos os limites da região a ser abrangida pelo processo de identificação, bem como estabelecer os objetivos a serem alcançados, sempre levando-se em conta os bens a proteger nela identificados.

A região de interesse pode ser um município, uma bacia hidrográfica, um estado, um bairro, uma região industrial, etc. A região de interesse deve ser representada em mapas, normalmente em escala regional, incluindo a localização dos bens a proteger. 
A definição da região de interesse e o estabelecimento dos objetivos do gerenciamento de áreas contaminadas estão relacionados à suas atribuições e aos interesses da instituição que deverá executar o gerenciamento, denominado órgão gerenciador.

No caso de um município, o órgão gerenciador será a prefeitura, no caso de um estado ou país, será a agência ambiental estadual ou federal, e no caso de instituições que desenvolvem atividades potencialmente contaminadoras, as próprias empresas privadas.

Definida a região de interesse, devem ser identificados os bens a proteger, pois esses são os principais elementos a serem considerados na tomada de decisão quanto aos procedimentos a serem adotados na avaliação dos riscos decorrentes da existência das áreas contaminadas.

São exemplos de bens a proteger, segundo GLOEDEN (1999):

- Qualidade das águas subterrâneas (regiões com aqüíferos importantes para o abastecimento),

- Áreas de proteção de poços (áreas de recarga, áreas vulneráveis),

- Qualidade do solo (uso e ocupação do solo, planejamento urbano),

- Qualidade das águas superficiais (qualidade do solo, das águas subterrâneas e superficiais em bacias hidrográficas utilizadas para abastecimento),

- Áreas de preservação ambiental (fauna e flora),

- Saúde da população (ocupação em áreas de conflito; zonas urbanas com elevada densidade populacional em contato com zonas industriais) e

- Áreas agrícolas (aplicação ou armazenamento de defensivos agrícolas e fertilizantes em condições inseguras, que podem prejudicar a qualidade dos alimentos e das águas).

O solo e a água subterrânea são meios prioritários a serem considerados no gerenciamento de áreas contaminadas, pois além de serem bens a proteger de extrema importância, normalmente, são as principais vias de propagação de contaminantes para outros bens a proteger. 
Desta forma, à definição dos objetivos do gerenciamento de áreas contaminadas em uma determinada região de interesse, a proteção da qualidade do solo e da água subterrânea devem ser prioritárias.

Para a definição da região de interesse, devem ser levantadas as bases para a determinação dos seus limites e o posicionamento dos bens a proteger no seu interior, utilizando-se mapas, normalmente, em escala regional.

Os mapas podem ser transportados para meios digitais, para a sua utilização em sistemas de informação geográfica, que permitem o cruzamento das informações levantadas, referentes aos bens a proteger, proporcionando a realização de priorizações e a obtenção de uma melhor representação gráfica.

\subsubsection{Identificação de áreas potencialmente contaminadas (APS)}

Após a definição da região de interesse, inicia-se a etapa de identificação de áreas potencialmente contaminadas, a partir da qual é estabelecido o conjunto inicial de áreas que constituirão o cadastro de áreas contaminadas.

Nesta etapa são identificadas as áreas potencialmente contaminadas, ou seja, as áreas onde são ou foram desenvolvidas atividades potencialmente contaminadoras, atividades essas onde ocorre ou ocorreu o manejo de substâncias cujas características físico-químicas, biológicas e toxicológicas podem acarretar riscos aos bens a proteger.

Com o objetivo de orientar a execução dessa etapa, deve-se inicialmente definir quais são as atividades potencialmente contaminadoras dos solos e águas subterrâneas existentes na região de interesse.

Em seguida, a identificação das áreas potencialmente contaminadas pode ser realizada por meio do levantamento de dados existentes, de investigações utilizandose fotografias aéreas e do recebimento e atendimento de denúncias ou reclamações. 
Esses resultados serão utilizados, posteriormente como base para a execução da etapa de avaliação preliminar e os dados obtidos, devem ser registrados no cadastro de áreas contaminadas, tratados e apresentados em base cartográfica com escala apropriada.

\subsubsection{Definição das atividades potencialmente contaminadoras (APCs)}

Em geral esta definição é baseada na natureza das substâncias utilizadas nos processos desenvolvidos nas áreas onde estas atividades são ou foram desenvolvidas e seu histórico (manuseio, acidentes e sua utilização).

As atividades potencialmente contaminadoras podem ser comerciais, industriais ou aquelas vinculadas a disposição de resíduos. Como exemplo de APCs comerciais podemos citar os aeroportos, postos de serviço, lavanderias e gráficas; para as APCs vinculadas a disposição de resíduos domésticos e/ou industriais, os incineradores, estações de tratamento de efluentes, aterros sanitários, industriais e lixões. Atividades industrias consideradas potencialmente contaminadoras podem ser aquelas ligadas ao tratamento de superfícies metálicas, atividades siderúrgicas e metalúrgicas e a indústria química, entre outras.

CETESB (1999), USEPA (1994) e FETTER (1993), sugerem listas de atividades que são consideradas potencialmente contaminadoras das águas subterrâneas e ao solo.

\subsubsection{Levantamento de dados existentes}

Esta etapa destina-se à obtenção de informações como razão social, logradouro, nome dos sócios, tempo de funcionamento, licenças de instalação e funcionamento e outras informações em entidades de controle ambiental, prefeituras, associações de indústria e comércio. Os orgãos que detém essas informações são denominados: fontes de informação. 
Essas informações devem ser armazenadas no banco de dados físico; denominado "ficha cadastral de áreas contaminadas", vide item 4.1.9. Destaca-se que as informações desta etapa utilizam principalmente o item 1 dessa ficha.

No caso específico de áreas desativadas, segundo GLOEDEN (1999), como antigas indústrias ou antigas áreas de disposição de resíduos, a identificação e avaliação desses locais pode ser realizada utilizando-se fotografias aéreas provenientes de vôos realizados em diferentes datas.

\subsubsection{Priorização 1}

Após a realização da etapa de identificação das áreas potencialmente contaminadas, a execução da etapa de priorização 1 visa, por meio de critérios previamente definidos, selecionar as áreas consideradas mais importantes, que deverão ser estudadas na etapa seguinte de avaliação preliminar.

As informações obtidas na etapa de identificação de áreas potencialmente contaminadas são, basicamente, a localização e a descrição da atividade potencialmente contaminadora desenvolvida em cada área e a localização dos bens a proteger, normalmente mapeados em escala regional.

Desta forma, a priorização das áreas potencialmente contaminadas deve ser realizada de maneira simples, estabelecendo-se critérios claros e objetivos.

Por exemplo, pode-se escolher áreas localizadas em regiões com bens importantes a proteger, como áreas de proteção de poços, aqüiferos com alta vulnerabilidade natural, ou áreas densamente populosas. Caso seja estabelecido que o objetivo principal do gerenciamento de áreas contaminadas, em uma determinada região de interesse, é proteger a qualidade das águas superficiais utilizadas para abastecimento, as áreas a serem priorizadas serão aquelas localizadas dentro das bacias hidrográficas dos reservatórios utilizados para abastecimento de água. 
Priorizar determinadas atividades industriais, com histórico de funcionamento associado a problemas ambientais, também é uma forma bem comum de selecionar áreas potencialmente contaminadas para a avaliação preliminar.

Os resultados desta etapa devem ser apresentados em relatório contendo os critérios utilizados, sua interpretação e mapas contendo a localização das áreas priorizadas na região de interesse.

\subsubsection{Avaliação preliminar}

A avaliação preliminar consiste na elaboração de diagnóstico inicial das áreas identificadas na etapa anterior. Nesta etapa a ficha cadastral de áreas contaminadas, apresentada no anexo I, torna-se o instrumento principal a ser utilizado, pois sua arquitetura foi desenvolvida para que os dados obtidos, tanto na coleta de dados existentes como na inspeção de reconhecimento da área, sejam ordenados de forma única, tanto no cadastro físico como no cadastro digital (cadastro de áreas contaminadas).

Os dados obtidos na etapa de avaliação preliminar permitem estabelecer uma primeira classificação das áreas identificadas inicialmente como potencialmente contaminadas, pela constatação de evidências ou fatos que levem a suspeitar ou não da existência de contaminação na área sob avaliação. De acordo com as observações efetuadas, as áreas podem ser classificadas como área potencialmente contaminada (AP), área suspeita de contaminação (AS), ou ainda podem ser excluídas do cadastro de áreas contaminadas

A etapa denominada avaliação preliminar é dividida em dois grupos de execução, a saber: coleta de dados existentes e inspeção de reconhecimento da área.

\subsubsection{Coleta de dados existentes}

A coleta de dados existentes pode ser subdividida em: estudo histórico e estudo sobre o meio físico. 
O estudo histórico possibilita a reconstituição das atividades realizadas em uma dada área, visa a compreensão sobre a quantificação e os produtos armazenados / utilizados / manipulados, disposição dos mesmos, reformas e ampliações a que a edificação foi submetida, posicionamento dos bens a proteger e outros. Essas informações podem ser obtidas em órgãos de controle ambiental, proprietário, meios de comunicação, prefeituras, bombeiros, junta comercial.

O estudo do meio físico objetiva, principalmente, a compreensão das vias potenciais de dispersão de uma possível contaminação, sua localização e características. Os dados podem ser obtidos em bibliotecas, unidades cartográficas, prefeituras, universidades.

Como exemplo, ao se efetuar a coleta de dados, em uma dada APC via processos de licenciamento, tanto para instalaçăo como para funcionamento de um dado estabelecimento, a descrição e definição dos materiais utilizados, produzidos e armazenados, são apontados nos itens: 3.4 (Materiais utilizados / produzidos / armazenados) e 5.1 (Substâncias presentes na área) da ficha cadastral

\subsubsection{Inspeção de reconhecimento da área}

A inspeção de reconhecimento da área pode ser subdividida em: vistoria ou observações de campo e entrevistas.

A vistoria ou observações de campo, na área em estudo visa a obtenção das informações que a "ficha cadastral de áreas contaminadas", vide Anexo 1, requer; como dados do projeto, manutenção e operação, impermeabilização de piso, ocorrência de vazamentos e infiltrações, presença de contaminantes, acidentes; ou seja, buscar evidências da presença de indicadores de contaminação. A partir dessa compilação são observados os dados de uso e ocupação do solo na vizinhança da área, enfocando os bens a proteger.

As entrevistas devem ser realizadas com pessoas que estiveram, estejam ou estão ligadas à área em estudo, as informações que devem ser apuradas são aquelas que podem fomentar ou agregar credibilidade à coleta de informaçôes, são exemplos de 
informações aquelas sobre a saúde ocupacional dos trabalhadores, incômodos na vizinhança (odor, trepidação, presença física de contaminantes), histórico de acidentes, formas de manuseio das substâncias, etc..

\subsubsection{Modelo conceitual}

O modelo conceitual definido no final da etapa de avaliação preliminar (modelo conceitual 1), constitui-se numa sintese do conhecimento adquirido sobre uma área até esta etapa do gerenciamento, devendo representar a sua situação quanto à possivel contaminação existente e sua relação com a vizinhança, incluindo os bens a proteger a serem considerados. Este modelo se constituirá na base para a definição dos objetivos, dos métodos e das estratégias a serem utilizados durante as etapas posteriores, devendo ser atualizado em função da execução de novas etapas do gerenciamento de áreas contaminadas.

$\mathrm{Na}$ ficha cadastral de áreas contaminadas, o modelo conceitual deve ser apresentado, no final de cada atualização, no seu item 10 (dez), denominado "Croqui da área/modelo conceitual".

\subsubsection{Classificação 1}

As informações obtidas durante a etapa de avaliação preliminar, possibilitam uma nova classificação da área potencialmente contaminada. O registro destas informações deve ser realizado utilizando-se a ficha cadastral de áreas contaminadas, que possui um sistema desenvolvido para a classificação das áreas (GLOEDEN, 1999).

Como exemplo de aplicação do sistema de classificação, as áreas onde esteja sendo feita ou foi realizada a disposição de resíduos de maneira inadequada, podem ser classificadas como áreas suspeitas de contaminação. Desta forma, devem ser observadas as respostas obtidas nos itens 2.1 ("tipo de disposição"), 2.6 ("existência de impermeabilização inferior"), 2.10 ("destino dos líquidos percolados"), 2.13 ("existência de impermeabilização superior") e 2.14 ("tipo de material utilizado para a impermeabilização superior") da ficha cadastral de áreas contaminadas, que dão 
subsídios para avaliar se a forma de construção e operação de áreas de disposição de residuos são adequadas.

No caso das áreas industriais e comerciais, bem como nos postos de serviço, podem ser consideradas como áreas suspeitas aquelas em que se considere que as atividades desenvolvidas na produção, armazenamento, tratamento e disposição final de residuos e efluentes, sejam realizadas de forma inadequada. Desta forma, devem ser observadas as respostas obtidas nos itens 3.6 ("destino das águas residuárias"), 3.8 ("condições de impermeabilização da área"), 3.9 ("material utilizado para impermeabilização da superfície do solo") e 3.10 ("existência de vazamentos/infiltrações"), que dão indicações sobre as condições das instalações e operação nesses empreendimentos.

No caso de fontes de contaminação desconhecidas ou outras fontes, como acidentes e fontes relacionadas à atividade agrícola, devem ser observados os itens 4.1 ("tipo de fonte de contaminação"), 4.2 ("causa do problema"), 4.5 ("destino das substâncias") e 4.6 ("existência de impermeabilização da superficie da área").

Em geral, para todos os tipos de fontes de contaminação, os itens 5.10 ("posição do nível d'água em relação aos contaminantes"), 5.15 ("possibilidade de influência da área sobre as águas superficiais") e 5.16 ("possibilidade de enchente na área") podem ser utilizados para classificar áreas como suspeitas de contaminação, pois indicam se existe a possibilidade de ocorrência de contato entre os contaminantes e os bens a proteger, no caso águas subterrâneas e superficiais.

Os itens 6.1 ("ocorrência de acidentes e eventos importantes"), 6.3 (existência de risco em decorrência da contaminação do solo"), 6.4 ("indicações perceptiveis na superfície do solo"), 6.5 ("presença de gases/vapores nas edificações vizinhas") podem indicar a ocorrência de eventos ou a presença de substâncias em determinados locais, que levem a suspeitar da presença de contaminação na área.

Por outro lado, os itens 5.8 ("existência de solo contaminado"), 5.11 ("existência de água subterrânea contaminada") e 5.14 ("existência de água superficial 
contaminada") subsidiam a classificação das áreas como áreas contaminadas (AC), considerando a constatação da existência de resultados analíticos e/ou presença de contaminante em fase livre, que atestem a existência de contaminação, por ocasião da realização de investigações na área, ou seja trabalhos correspondentes no mínimo aos trabalhos realizados na etapa de investigação confirmatória (classificação 2), necessários para definir uma área como contaminada.

Desta forma, para classificar uma área como suspeita de contaminação, pelo menos uma das respostas às questões apresentadas deve indicar suspeita de contaminação na área (GLOEDEN, 1999).

$\mathrm{Na}$ figura 4.3 a tomada de decisão é representada graficamente; segundo as atividades comerciais /ou industriais, a descrição da área e suas adjacências e os itens da ficha cadastral (materiais utilizados/produzidos/armazenados; existência de vazamentos/infiltrações; ocupação do solo; influência direta (águas)).

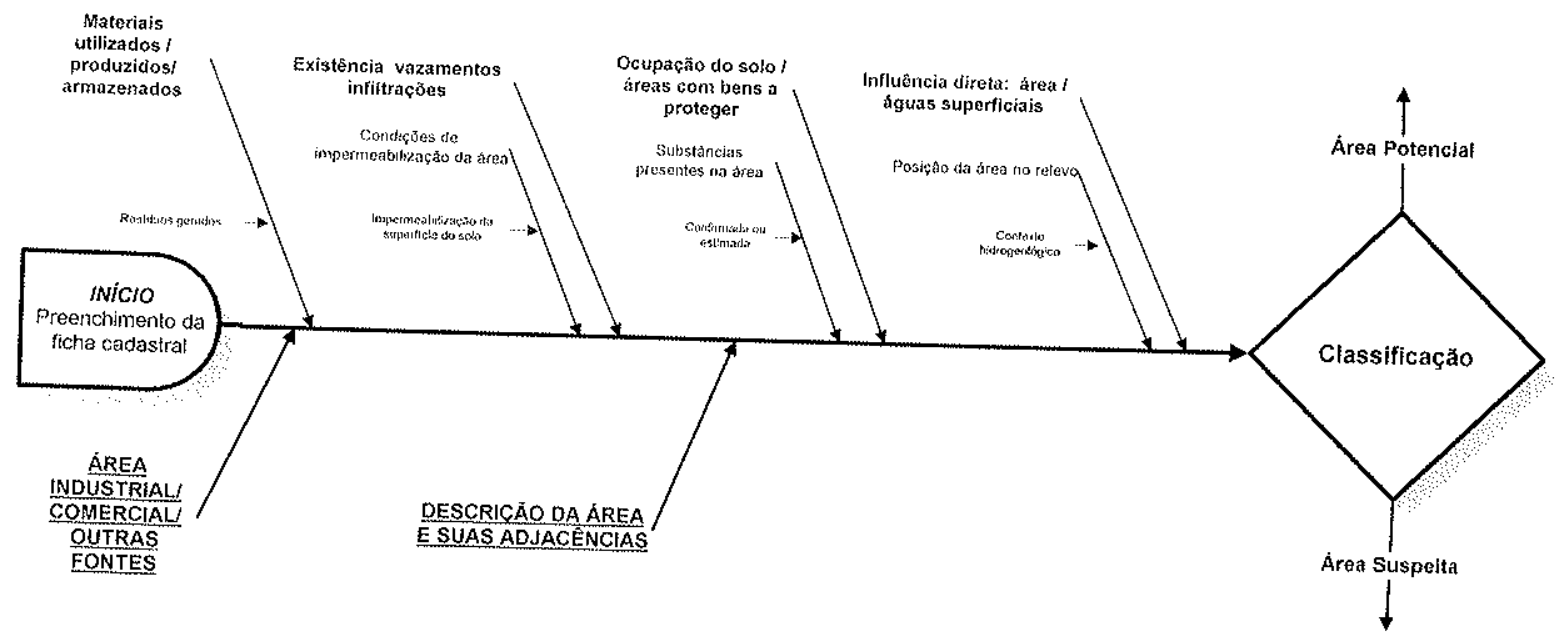

Figura 4.3 Fluxograma de tomada de decisão para a classificação 1.

4.1.5 Apresentação dos resultados da etapa de avaliação preliminar

Os resultados obtidos na etapa de avaliação preliminar devem ser apresentados em relatórios e armazenados no cadastro de áreas contaminadas, juntamente com as fichas cadastrais das áreas avaliadas.

As novas classificações recebidas pelas áreas em questão na etapa de avaliação preliminar deverão ser atualizadas nos mapas regionais elaborados nas etapas de 
definição da região de interesse e identificação de áreas potencialmente contaminadas.

\subsubsection{Priorização 2}

A etapa de priorização 2 é realizada nas áreas classificadas como suspeitas de contaminação após a realização da avaliação preliminar. São selecionadas, com base em critérios preestabelecidos aquelas consideradas prioritárias para serem estudadas, na etapa seguinte denominada "investigação confirmatória".

O nivel de conhecimento atingido após a execução da etapa de avaliação preliminar, segundo GLOEDEN (1999), permite a aplicação de diferentes metodologias, com a finalidade de estimar os riscos associados aos bens a proteger considerados, causados pela áreas avaliadas. A USEPA utiliza uma metodologia denominada "Hazardous Ranking System", para selecionar as áreas a serem incluidas na Lista Nacional de Prioridades (NPL) do "Superfund". No Canadá utiliza-se o Sistema Nacional de Classificação de Locais Contaminados ("NCS"), que atribui graus de risco alto, médio ou baixo para cada área, visando selecionar áreas prioritárias para recebimento de recursos para investigação e remediação.

A metodologia de pontuação desenvolvida e utilizada no Gerenciamento de Áreas Contaminadas - Projeto CETESB/GTZ, foi baseada na metodologia adotada pelo Estado alemão de Nordrhein - Westfalen. Esse sistema é utilizado, neste estado da Alemanha, para priorização de áreas suspeitas e contaminadas, visando a seleção de áreas prioritárias para receberem recursos financeiros federais para investigação e remediação.

A pontuação é efetuada por meio de uma ficha criada especificamente para esta finalidade, a ficha de pontuação de áreas contaminadas. Esta está organizada de forma a que, no seu preenchimento, atribui-se para cada área avaliada uma pontuação relativa ao riscos gerados aos bens a proteger identificados na área ou arredores. Essa pontuação leva em consideração as características da fonte de contaminação, as vias de transporte dos contaminantes e os bens a proteger. As pontuações obtidas em diferentes áreas suspeitas de contaminação podem ser 
comparadas entre si, visando a priorização destas por ranqueamento, ou seja, quanto maior a pontuação, maiores os riscos aos bens a proteger avaliados.

A ficha de pontuação de áreas contaminadas é composta basicamente por quatro partes, sendo cada uma destas denominadas critérios de priorização:

- Critério principal 1 (CP1): informações gerais sobre a área;

- Critério principal 2 (CP2): resíduos/substâncias;

- Critério principal 3 (CP3): ocupação do solo/áreas com bens a proteger;

- Critério principal 4 (CP4): propagação.

Os bens a proteger considerados na pontuação, são:

- BP1 - Vida e saúde da população (impacto direto),

- BP2 - Abastecimento de água potável,

- BP3 - Uso do solo residencial com hortas,

- BP4 - Recursos hídricos (subterrâneos e superficiais),

- BP5 - Uso do solo para atividade agrícola ou pecuária,

- BP6 - Outros bens a proteger (patrimônio público, ecológico, etc.).

A pontuação total indicativa do risco a cada bem a proteger $(P)$ é obtida pela aplicação da seguinte equação:

$$
P=(C P 1+C P 2) \times C P 3 \times C P 4
$$

Os valores máximos para a soma dos critérios principais 1 e 2 , e para os critérios principais 3 e 4 devem ser menores ou iguais a 10. Desta forma, são obtidas 6 pontuações referentes a cada um dos bens a proteger, que devem ser menores ou igual a 1000 .

As pontuações podem ser utilizadas de diversas formas na etapa de priorização. Pode-se, por exemplo, considerar a nota para um único bem a proteger de maior interesse ou mesmo para um conjunto desses. 
Vale salientar que no cadastro de áreas contaminadas do Projeto CETESB/GTZ, a pontuação é realizada automaticamente pelo banco de dados.

\subsubsection{Investigação confirmatória}

A etapa de investigação confirmatória encerra o processo de identificação de áreas contaminadas e tem como objetivo principal confirmar ou não a existência de contaminação e verificar a necessidade da realização de uma investigação detalhada nas áreas suspeitas, identificadas na etapa de avaliação preliminar. Desta forma, os resultados obtidos na etapa de investigação confirmatória são importantes para subsidiar as ações do órgão gerenciador ou órgão de controle ambiental na definição do responsável pela contaminação e dos trabalhos necessários para a solução do problema.

A confirmação da contaminação em uma área dá-se basicamente pela tomada de amostras e análises de solo e/ou água subterrânea, em pontos estrategicamente posicionados. Para locar esses pontos e definir a profundidade de investigação tomase como base o conhecimento adquirido sobre a área na etapa anterior (avaliação preliminar), onde foi definido o primeiro modelo conceitual da área (modelo conceitual 1).

Em seguida, deve ser feita a interpretação dos resultados das análises realizadas nas amostras coletadas, pela comparação dos valores de concentração obtidos com os valores de concentração estabelecidos em listas de padrões, definidas pelo órgão responsável pelo gerenciamento de áreas contaminadas.

Desta forma, caso uma área, após a execução da etapa de investigação confirmatória, seja classificada como área contaminada ( $A C)$, haverá a necessidade da execução das etapas seguintes do processo de recuperação de áreas contaminadas. Caso contrário, ela permanecerá classificada como área potencialmente contaminada (AP), devendo permanecer registrada aguardando novas informações, ou ainda poderá ser excluída do cadastro, quando não for detectada a 
contaminação nessa e quando não mais existir atividades potencialmente contaminadoras em funcionamento no local.

A metodologia utilizada para realização da etapa de investigação confirmatória é constituída basicamente pelas seguintes partes: plano de amostragem, coleta de amostras, realização de análises, interpretação dos resultados e definição do responsável pela contaminação

\subsubsection{Plano de amostragem}

Em função da grande variabilidade de tipos de áreas suspeitas de contaminação que necessitam ser investigadas (diferentes tipos de fontes de contaminação, contaminantes, vias de transporte e receptores ou bens a proteger), não pode ser aplicada uma forma única para definição do plano de amostragem. Entretanto, uma seqüência de procedimentos comuns podem ser sugeridos para a definição deste plano.

Desta forma, na elaboração de um plano de amostragem na etapa de investigação confirmatória devem ser definidos basicamente:

A Os meios a serem amostrados;

B O número, profundidade e a localização dos pontos de amostragem;

C Os parâmetros a serem analisados;

D As técnicas e protocolos de amostragem, preparação de amostras e análises;

E O número de campanhas de amostragem;

$F \quad$ Os valores limites das concentrações dos contaminantes a serem considerados;

G O plano de infraestrutura e segurança dos trabalhadores;

H A equipe de profissionais que participarão da execução desta etapa.

Destaca-se, novamente, que a base principal para o planejamento dos trabalhos é o modelo conceitual 1 , desenvolvido na etapa de avaliação preliminar, que fornece uma visão dos tipos de informação necessários a serem levantados na etapa de investigação confirmatória. 
As estratégias, propostas pela CETESB (1999), para a elaboração de plano de amostragem dos solos e águas subterrâneas em áreas suspeitas de contaminação na etapa de investigação confirmatória, visam uniformizar a forma de execução da etapa de investigação confirmatória no Estado de São Paulo, ou seja, uniformizar os procedimentos utilizados para deciarar uma área como contaminada.

Na figura 4.4 e quadro 4.1 são apresentadas as estratégias propostas pela CETESB (1999) para a elaboração de plano de amostragem dos solos e águas subterrâneas em áreas suspeitas de contaminação na etapa de investigação confirmatória. Estas propostas visam uniformizar a forma de execução da etapa de investigação confirmatória no Estado de São Paulo; ou seja, uniformizar os procedimentos utilizados para declarar uma área contaminada. 


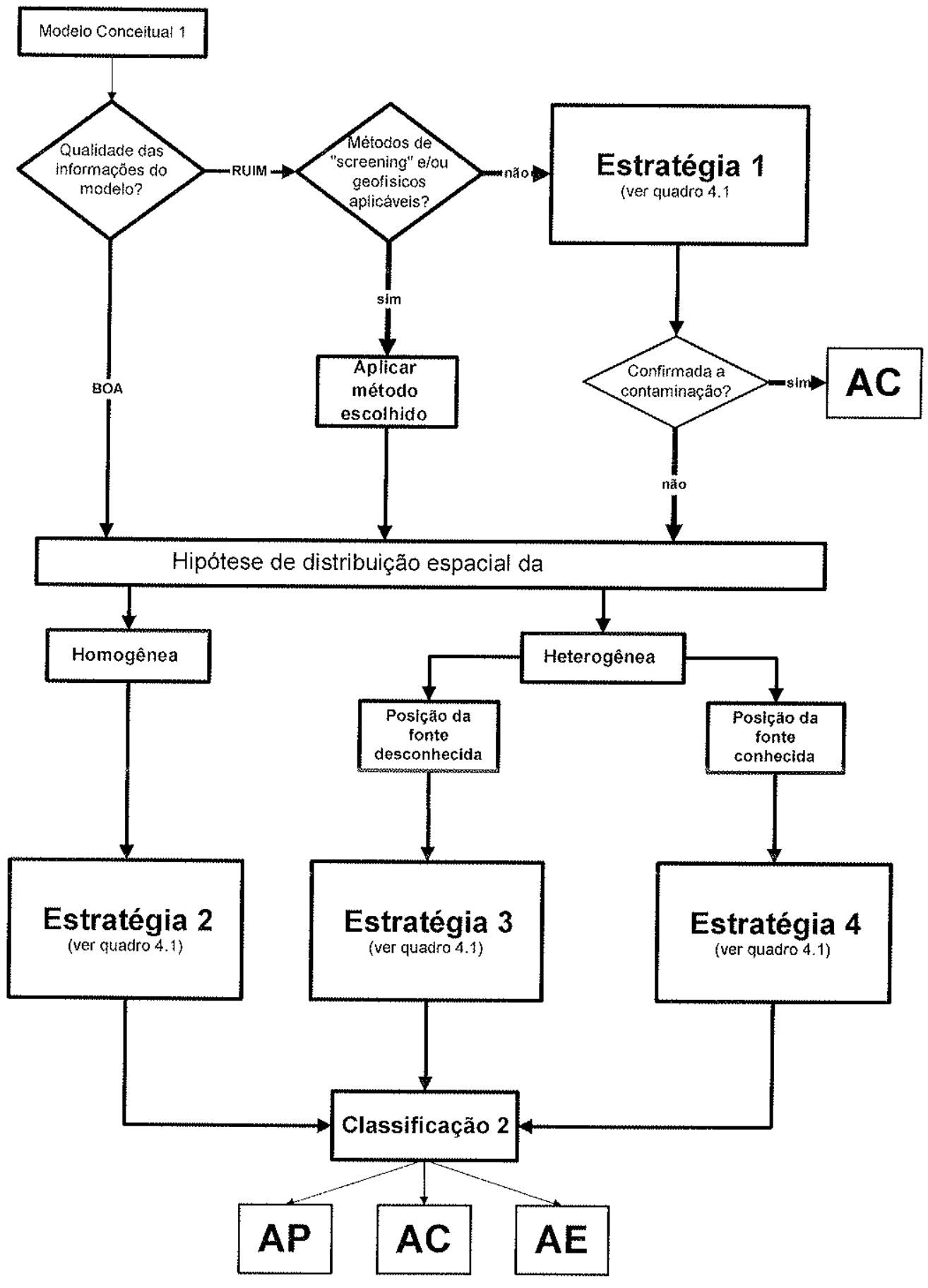

Fonte: CETESB, 1999 (modificado)

Figura 4.4 Proposta de estratégias para a elaboração de plano de amostragem de solo e água subterrânea na etapa de investigação confirmatória. 


\section{Quadro 4.1: Estratégias de amostragem de solo e águas subterrâneas na etapa de investigação confirmatória}

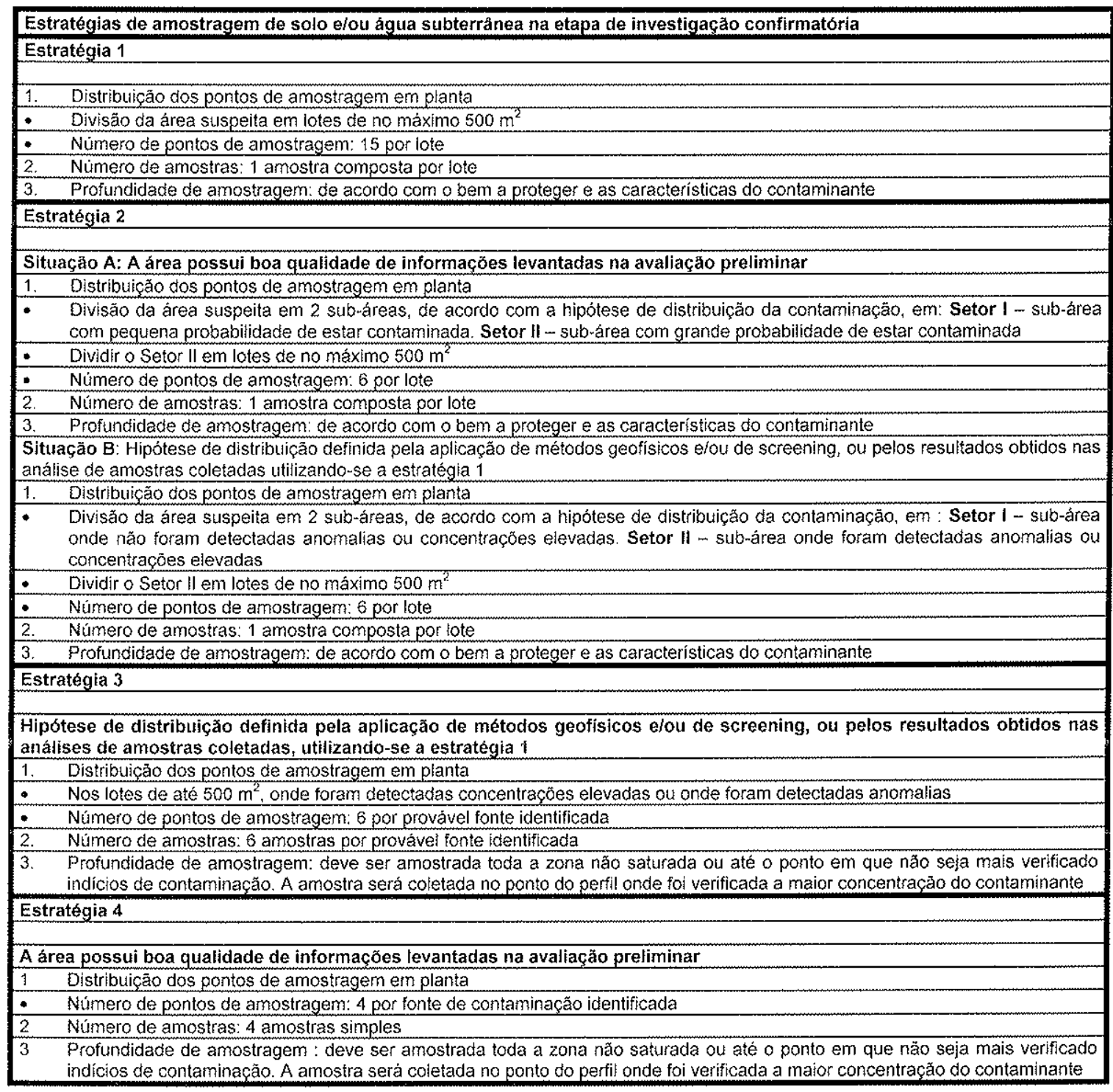

\subsubsection{Classificação 2}

A concentração dos contaminantes identificados nos meios amostrados devem ser comparados aos valores limites estabelecidos. Caso os valores obtidos estejam acima destes, a área em questão poderá ser classificada como uma área contaminada (AC). Se estiverem abaixo, a área poderá ser classificada como potencialmente contaminada ou ser excluída do cadastro de áreas contaminadas.

Os resultados da etapa de investigação confirmatória devem ser utilizados para atualizar as informações armazenadas no cadastro de áreas contaminadas. Na ficha 
cadastral de áreas contaminadas (ver anexo 1), os itens 5.8 ("existência de solo contaminado"), 5.11 ("existência água subterrânea contaminada") e 5.14 ("existência de água superficial contaminada") estão associados a classificação das áreas como contaminadas. As áreas classificadas como áreas contaminadas (ACs) devem passar a ser avaliadas nas etapas seguintes do gerenciamento, sendo enquadradas no processo de recuperação das áreas contaminadas.

\subsubsection{A ficha cadastral de áreas contaminadas}

A ficha cadastral de áreas contaminadas, que pode ser observada no anexo 1 , foi elaborada de modo a ser o instrumento orientador da coleta e organização de dados relativos às áreas sob avaliação. Pode ser definida como a base para a alimentação, dos dados coletados, no cadastro de áreas contaminadas.

As questões da ficha foram elaboradas para que se possa identificar ou se comprovar a existência de contaminação na área e/ou se na mesma existem fontes suspeitas, representativas, de contaminação.

Outro aspecto importante é a identificação dos bens a proteger e das principais vias de propagação dos contaminantes na área e adjacências.

Desta forma, segundo GLOEDEN (1999), a estrutura da ficha cadastral de áreas contaminadas é baseada em itens, que foram agrupados de forma a se obter dados e informações referentes aos diferentes aspectos envolvidos na avaliação de uma área. Esses itens serão descritos a seguir:

- Informações cadastrais sobre a área (identificação, localização) (item 1);

- Dados relativos à natureza e características da fonte de contaminação (disposição de resíduos - item 2 , fontes industriais, fontes comerciais, postos de serviço - item 3 , outras fontes, fontes não conhecidas - item 4);

- Dados sobre os bens a proteger localizados na área e em suas adjacências (item 5);

- Dados indicativos da presença ou não de contaminação na área e adjacências (item 5). 
- Dados indicativos da forma de propagação dos contaminantes (item 5 e 6);

- Dados indicativos da possibilidade dos contaminantes atingirem bens a proteger (item 5 e 6);

- Informações sobre as ações adotadas em relação à avaliação, investigação e remediação da área (item 7);

- Informações sobre as fontes de informação utilizadas (item 8);

- Informações gerais (item 9);

- Representação do modelo conceitual da área (item 10);

- Representação da localização da área em mapa (item 11).

O primeiro preenchimento da ficha cadastral de áreas contaminadas, deve ser realizado na etapa de identificação de áreas potencialmente contaminadas, quando é respondido basicamente o seu item 1 ("identificação da área").

A ficha é atualizada durante a execução das etapas de avaliação preliminar, investigação confirmatória e demais etapas do processo que fazem parte do gerenciamento de áreas contaminadas. Desta forma, após cada uma destas etapas será efetuada a atualização do cadastro de áreas contaminadas (GLOEDEN, 1999).

Com base nas informações registradas na ficha cadastral, as áreas podem ser classificadas como áreas potencialmente contaminadas (APs), áreas suspeitas de contaminação (ASs), ou áreas contaminadas (ACs).

A ficha cadastral de áreas contaminadas possui um sistema para orientar a realização das classificações 1,2 e 3 , previstas na metodologia do gerenciamento de áreas contaminadas (ver itens $4.1 .4 ; 4.1 .8$ ).

O registro da classificação da área é realizado no item 1.12 da ficha cadastral. Este item deve ser preenchido no final de cada etapa do gerenciamento, após serem respondidos todos os demais itens referentes à etapa em execução.

Os itens da ficha cadastral que podem ser utilizados para realizar a classificação das áreas ou para excluí-las do cadastro, têm ao seu lado os campos AP( ), AS( ), AC( ) 
e $A E($ ), os quais devem ser assinalados, de acordo com as informações levantadas e o conseqüente preenchimento do item especifico.

Um único item afirmativo é suficiente para classificar a área de acordo com a seguinte ordem hierárquica: AC predomina sobre AS e esta sobre AP.

As informações obtidas no preenchimento da ficha cadastral de áreas contaminadas são utilizadas no sistema de pontuação, desenvolvido para realizar as etapas de priorização 2 (ver item 4.1.6) e 3.

Os itens da ficha cadastral, que são utilizados no sistema de pontuação de áreas contaminadas, recebem siglas que se relacionam aos item da ficha de pontuação correspondentes. Estas siglas e seu significado são apresentados a seguir:

- CP1 - critério principal 1;

- CP2 - critério principal 2;

- CP3 - critério principal 3;

- PAS - propagação via águas subterrâneas;

- PASP - propagação via águas superficiais;

- PS - propagação via solo;

- PA - propagação via ar.

\subsection{1 o Cadastro de Áreas Contaminadas}

O cadastro de áreas contaminadas é o instrumento central do gerenciamento. Nele são registradas todas as informações adquiridas durante a execução das etapas do gerenciamento.

Os dados armazenados no cadastro de áreas contaminadas devem ser consultados para subsidiar a adoção de medidas voltadas à remediação de áreas contaminadas, para auxiliar na seleção de medidas preventivas de controle ambiental e dar subsídios para o planejamento urbano. 
A entrada de dados no cadastro é iniciada na etapa de identificação de áreas potencialmente contaminadas. Após a execução de cada uma das demais etapas do gerenciamento, atualizações devem ser feitas e inseridas no cadastro.

As informações coletadas nessas etapas podem ser armazenadas nas duas partes constituintes do cadastro de áreas contaminadas: o cadastro físico e o cadastro informatizado.

\subsubsection{Cadastro fisico}

No cadastro físico, devem ser armazenados todos os documentos em papel utilizados para levantar as informações, tais como as fichas cadastrais e de pontuação, mapas temáticos diversos e relatórios, bem como cópias dos documentos originais onde estas foram registradas.

Também devem ser mantidos no cadastro físico os projetos de remediação, os registros dos documentos legais, por exemplo, os documentos de aprovação do projeto de remediação e os relatórios de acompanhamento da remediação.

\subsubsection{Cadastro informatizado}

O cadastro informatizado pode ser constituído por um banco de dados alfanuméricos, que pode estar associado a um sistema geográfico de informações (SGI). Essa ligação é muito útil pela própria natureza gráfica do $S G I$, que permite uma visualização da região em estudo, tanto regionalmente como de forma específica para cada área cadastrada, facilitando o planejamento das ações a serem adotadas.

O programa gerenciador do banco de dados deve controlar a entrada, atualização e exclusão das informações, permitir a emissão de relatórios de pesquisas e o cruzamento de informações, além de realizar o cálculo do sistema de pontuação (ver item 4.1.8), baseado nos critérios descritos no item 4.1.6 ("Priorização 2"). 
Na figura 4.5 será demonstrado o esquema de entrada de dados, tanto no cadastro físico como no informatizado; bem como as ações que representam cada etapa no universo de coleta de informações de uma área.

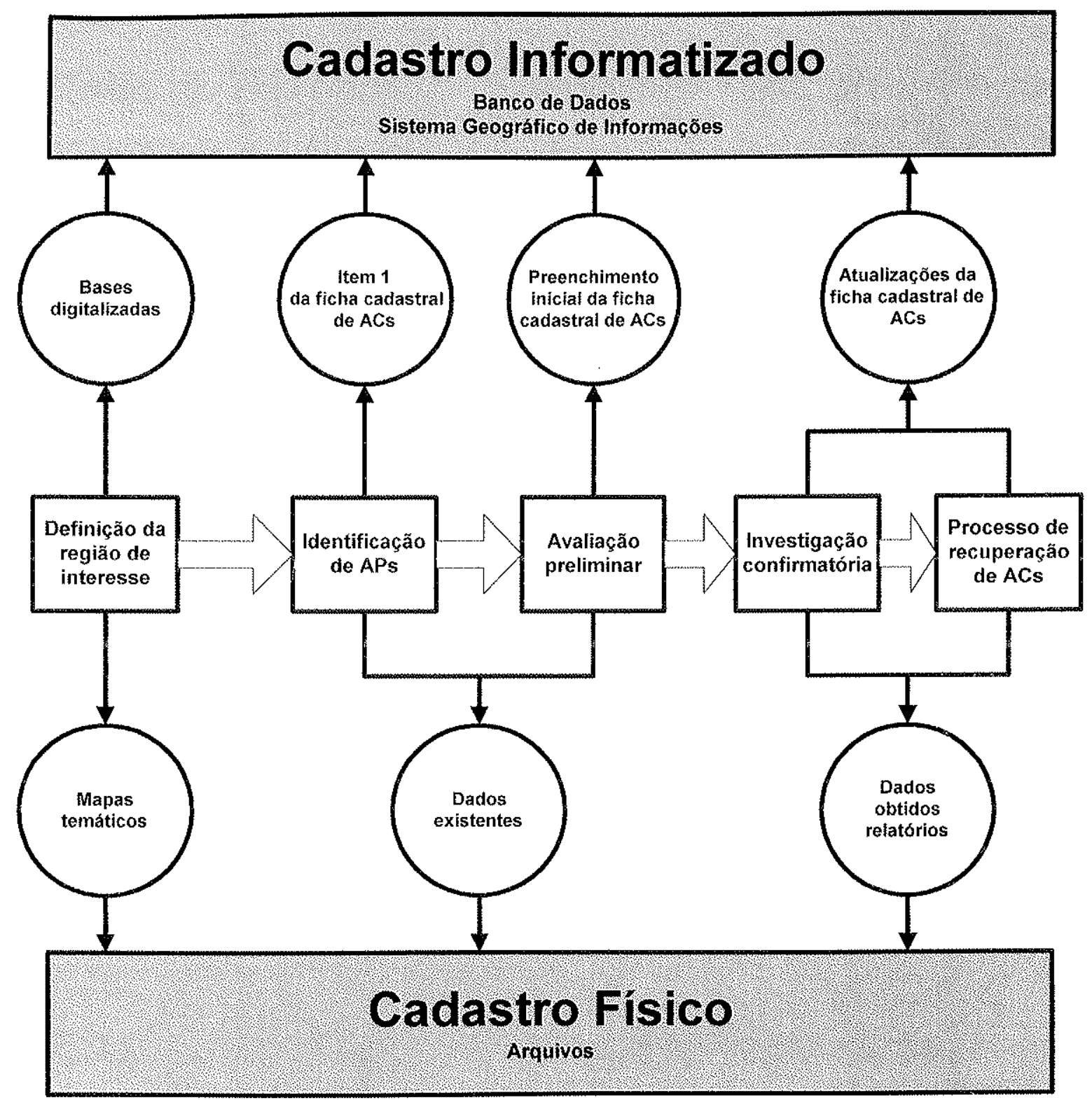

Fonte: GLOEDEN, 1999.

Figura 4.5 o esquema de entrada de dados no cadastro de áreas contaminadas.

A base cartográfica que compõe o SGI deve compreender os limites da região de interesse, a mancha urbana, as vias de circulação, geologia, hidrografia, áreas de proteção elou restrição legal, localização de poços de abastecimento, mapas de 
profundidade do nivel d'água subterrânea, perimetros de proteção de poços, mapas de uso do solo e as localizações das áreas potencialmente contaminadas, suspeitas de contaminação e contaminadas identificadas.

Os mapas podem ter escalas variadas, que dependem da etapa do gerenciamento de áreas contaminadas em execução. Estas áreas podem ser representadas como pontos ou polígonos, de acordo com o nivel de detalhe da informação existente. Por exemplo, como resultado da etapa de identificação de áreas potencialmente contaminadas, estas são representadas como pontos em mapas em escalas regionais. Na etapa de avaliação preliminar as áreas suspeitas de contaminação podem ser representadas por polígonos correspondentes a área da propriedade, em mapas com maior detalhe. $\mathrm{Na}$ etapa de investigação detalhada as áreas contaminadas podem ser representadas por polígonos correspondentes a área afetada pela contaminação em mapas ainda mais detalhados (GLOEDEN, 1999).

Os dados cadastrados no SGI, juntamente com o banco de dados, permitem a realização de pesquisas gráficas, onde o usuário pode indicar um ponto ou uma área do mapa da região de interesse e ter acesso às informações disponiveis, imagens e textos digitalizados relacionados ao local.

A forma de processamento de dados no cadastro informatizado é sintetizado na figura 4.6 . 


\section{ENTRADAS PROCESSAMENTO SAÍDAS}

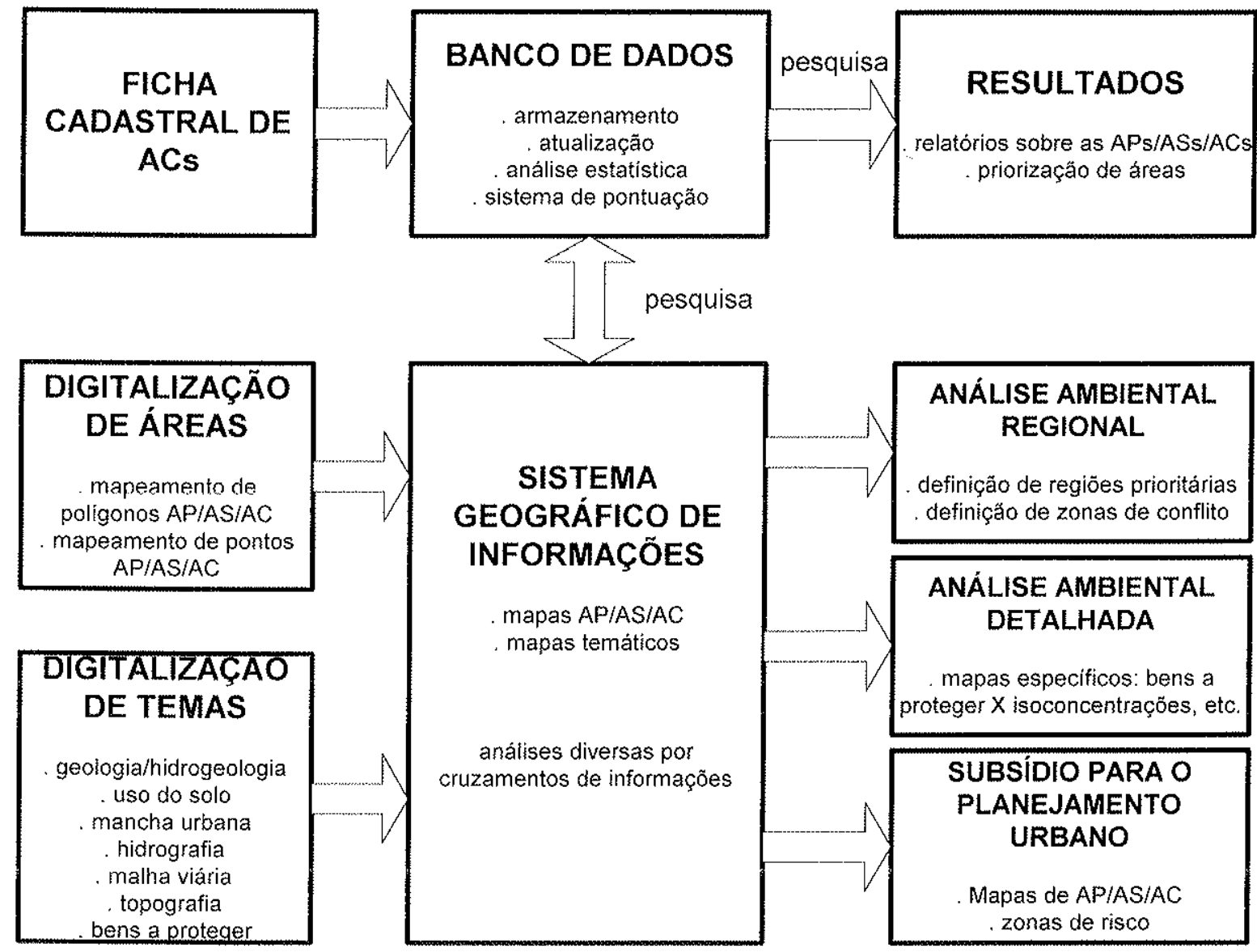

Fonte: CETESB (1999).

Figura 4.6 Processamento de dados referentes às áreas contaminadas.

4.2 Política de Proteção de Solos - Comunidade Autônoma do País Basco (CAPB), "Sociedad Pública Gestión Ambiental" -(IHOBE).

\subsubsection{Objetivos da politica de proteção aos solos}

Os objetivos do plano diretor, implementados pelo Departamento de Ordenação Territorial, Moradia e Meio Ambiente e difundidos pelo IHOBE, são:

- Evitar situações de exposição perigosa para as pessoas,

- Proteger a qualidade das águas superficiais e subterrâneas, 
- Proteger os ecossistemas e facilitar o processo de regeneração urbana sem criar pendências para as futuras gerações.

\subsubsection{Definição e estrutura de gestão da política global para a proteção do solo.}

A atuação técnica do IHOBE, através de sua Oficina Técnica de Solos, pode ser dividida em duas partes distintas denominadas: política sistemática e plano de investigações e infra-estruturas básicas.

- A política sistemática pode ser definida como sendo um conjunto de passos que sâo iniciados com um levantamento histórico dos solos potencialmente contaminados, culminando na adoção de técnicas de recuperação desses.

O plano de investigações e infra-estruturas básicas, está relacionado a adoção de ações necessárias para a identificação e investigação dos solos contaminados.

\subsubsection{Incorporação de atividades potencialmente contaminadoras ao processo de investigação}

A identificação de atividades potencialmente contaminadoras é o mecanismo que inicia o sistema de investigação e avaliação dos solos contaminados. As atividades potencialmente contaminadoras indicadas pelo IHOBE (1994) são as seguintes: disposição de resíduos sólidos, líquidos e pastosos; injeção de resíduos liquidos; derramamentos acidentais; vazamentos durante operações variadas (rupturas de tubulação, furos em tanques; armazenamento e transporte de matérias primas, produtos elaborados e resíduos; aplicação de lodos de efluentes industriais no solo, deposição de material particulado sólido via aérea).

\subsubsection{As etapas de investigação em solos contaminados.}

Uma vez detectados indícios de possiveis contaminações em uma dada atividade, área ou local, inicia-se uma investigação da qualidade do solo, ajustada ao esquema que se observa na figura 4.6. Vale ressaltar que a área em questão será incluida no "inventário de áreas com atividades potencialmente contaminadoras do solo". 


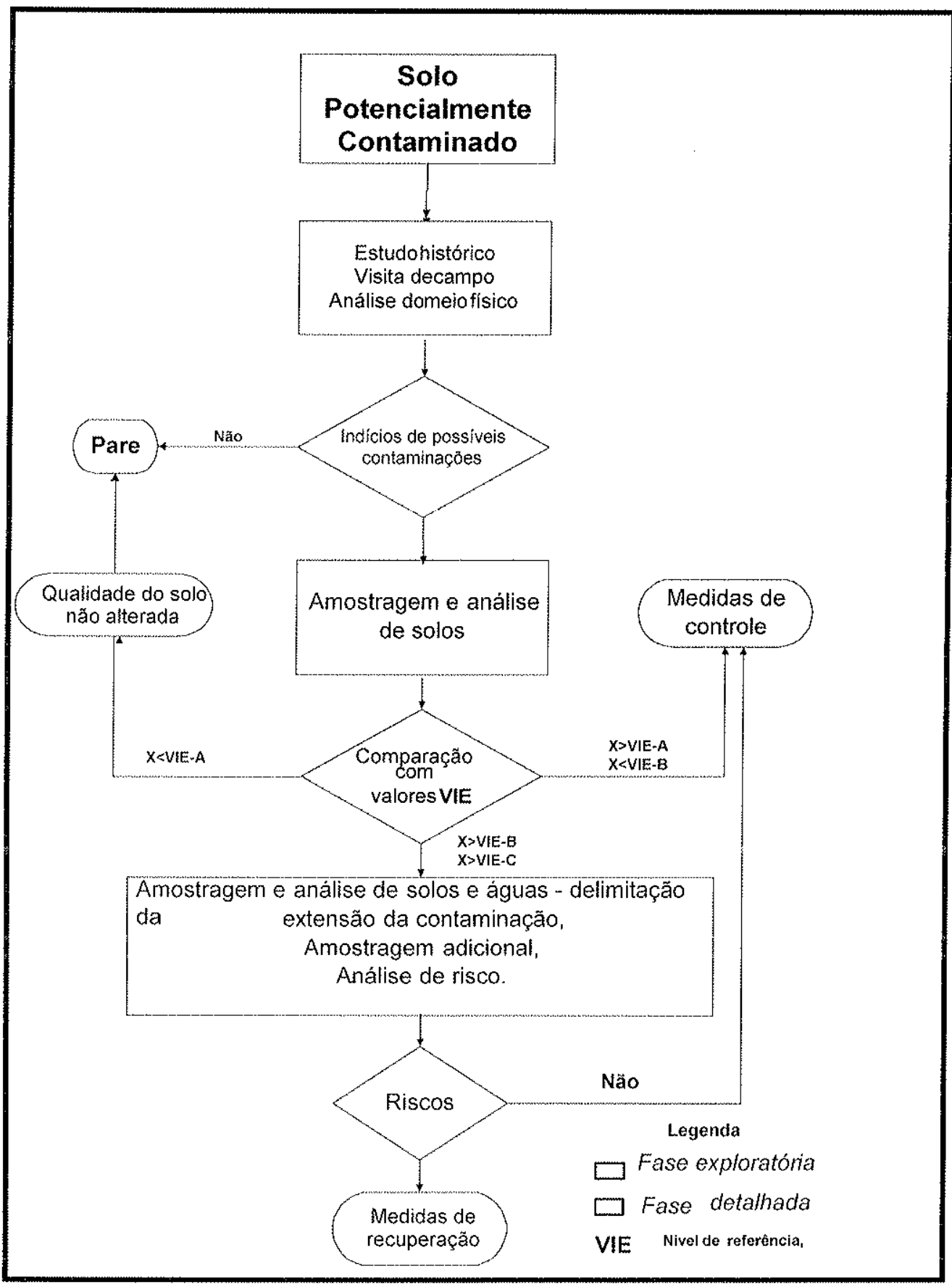

Fonte: IHOBE (1998).

Valor VIE-A ou nivel de referência:

Valor VIE - B: valor indicativo de avaliaçăo, marca o limite inferior à aceitabilidade do risco.

Valor VIE - C Ou o máximo de risco tolerável: Este valor de qualidade representa o limite superior da aceitabilidade do risco. Sua superaçăo implica em perigo grave para a saúde humana e ao funcionamento dos ecossistemas. $x=$ valor encontrado.

Figura 4.6 Esquema das etapas de investigação em solos contaminados segundo IHOBE. 


\subsubsection{Fase Exploratória}

Antes de se levar a cabo uma campanha de amostragem e de análises químicas, que podem ser extremamente onerosas, é necessário em todos os casos realizar a coleta de dados existentes relevantes à área em estudo. Os resultados dessa investigação quando possuem uma qualidade aceitável, podem ser suficientes para estabelecer a necessidade de se paralisar ou de se continuar o processo de investigação.

Os objetivos principais da fase exploratória são os seguintes:

- Comprovar a probabilidade de que exista uma contaminação no solo que possa afetar aos usos atuais e previstos, indicar a natureza e distribuição dessa,

- Proporcionar a informação necessária para o desenho da estratégia de amostragem e análises da fase seguinte de investigação,

- Identificar aquelas circunstâncias que podem colocar em perigo a saúde e a segurança das pessoas e trabalhadores.

A fim de se alcançar esses objetivos, devem ser realizadas as seguintes etapas:

- Estudo histórico: Uma vez detectados indícios de possíveis contaminações em um dado empreendimento, ou pela sua inclusão no Inventário de empreendimentos com atividades potencialmente contaminadoras do solo, deve ser iniciada uma investigação na área com o objetivo de detectar indícios que levem a suspeitar da presença de contaminação.

- Visita a campo: com o objetivo de se confirmar as informações levantadas anteriormente e de se inspecionar o estado atual da área,

- Análise do meio físico: Esta informação será utilizada junto às anteriores com a intenção de se elaborar um modelo conceitual da área em referência aos contaminantes bem como os cenários de riscos de exposição e dispersão da contaminação. 
Uma vez detectadas evidências de possibilidades de ocorrência de contaminação na área parte-se para a elaboração de uma plano de amostragem de solos e águas subterrâneas (fase detalhada), visando confirmar ou não a presença de contaminação da área. Caso esta seja confirmada deverá ser elaborado um plano para a realização de estudos de avaliação de riscos para definição das intervenções a serem tomadas na área.

4.2.6 Valores indicativos de avaliação (VIE - A, VIE - B, VIE - C)

A contaminação do solo impõe aos ecossistemas terrestres uma alteração, preferencialmente de natureza quimica, frente ao qual o sistema pode experimentar ou não os efeitos adversos dependendo das características da perturbação ou contaminação (intensidade, duração e freqüência) e do meio afetado (capacidade de resposta frente ao estresse).

Os valores indicativos de avaliação, são definidos como sendo os padrões de qualidade do solo e são distribuídos em três niveis. O primeiro nivel é conhecido pela sigla VIE - A, que define o conceito de alteração prejudicial do solo, enquanto que VIE - B e VIE - C estão estritamente ligados à determinação da contaminação do solo.

A principal função, dos valores indicativos são de fornecer apoio ao processo de análise de risco, pois ambos permitem uma avaliação genérica nơ fase exploratória da investigação da qualidade do solo de uma área potencialmente contaminada. Os cenários de exposição onde são utilizados os valores indicativos em análises de risco, são: residências com hortas, residências sem hortas, parque público, uso industrial/comercial e uso natural da área. A definição desses cenários de exposição são ajustados às condições especiais quando as características de um determinado solo são alteradas por uma atividade potencialmente contaminadora. Das 46 (quarenta e seis) substâncias orgânicas e inorgânicas que foram diagnosticadas por meio de um estudo histórico sobre a tipologia fabril do País Basco, as que foram consideradas prioritárias na questão da contaminação dos solos, são: os metais pesados, os cianetos, o hexaclorociclohexano, os fenóis, os compostos aromáticos 
(BTEX), os hidrocarbonetos policíclicos aromáticos (PAHs), as bifenilaspolicloradas (PCBs), as dioxinas, os solventes clorados e o óleo mineral.

No quadro 4.2, são descritas as substâncias que segundo o estudo histórico realizado, são consideradas as causas mais prováveis de contaminação química dos solos. Esses contaminantes estão divididos em dois grupos definidos segundo o que foi definido como: Caráter de urgência para se definir os padrões de solo, com a intenção de se utilizar esses padrões como indicadores em avaliações de áreas potencialmente contaminadas.

Quadro 4.2 Lista dos contaminantes mais comuns nos solos do Pais Basco.

\begin{tabular}{|c|c|}
\hline Grupo 1 & Grupo 2 \\
\hline $\begin{array}{c}\text { Metais } \\
\text { Arsênio } \\
\text { Cádmio } \\
\text { Chumbo } \\
\text { Cobre } \\
\text { Cromo } \\
\text { Mercúrio } \\
\text { Molibdênio } \\
\text { Niquel } \\
\text { Zinco } \\
\text { Outros compostos inorgânicos } \\
\text { Cianeto } \\
\text { Compostos aromáticos }\end{array}$ & $\begin{array}{l}\text { Solventes clorados } \\
\text { Clorobenzeno } \\
\text { Monoclorofenol } \\
\text { Diclorofenol } \\
\text { Triclorofenol } \\
\text { Tetraclorofenol } \\
\text { Pentaclorofenol } \\
\text { Diclorometano } \\
\text { Triclorometano } \\
\text { Tetraclorometano } \\
\text { Tricloroetileno } \\
\text { Dicloetano } \\
\text { Cloreto de vinila }\end{array}$ \\
\hline $\begin{array}{c}\text { Benzeno } \\
\text { Etilbenzeno } \\
\text { Tolueno } \\
\text { Xileno } \\
\text { Fenóis } \\
\text { Hidrocarbonetos policíclicos aromativos } \\
\text { Antraceno } \\
\text { Benzo(a)antraceno } \\
\text { Benzo(a)pireno } \\
\text { Benzo(ghi)perileno } \\
\text { Benzo(k)fluoranteno } \\
\text { Criseno } \\
\text { Fenantreno } \\
\text { Fluorantreno } \\
\text { Indeno(1,2,3-cd)pireno } \\
\text { Naftaleno } \\
\text { Compostos clorados } \\
\text { Bifenilas policloradas } \\
\text { Dioxinas } \\
\text { Furanos } \\
\text { Hexaclorocicloxing } \\
\text { Outros compostos orgânicos } \\
\text { Oleo mineral }\end{array}$ & \\
\hline
\end{tabular}




\subsection{Justificativa de opção metodológica.}

As metodologias descritas possuem muitas partes em comum, como por exemplo, a definição de atividades potencialmente contaminadoras do solo $e$ águas subterrâneas, coleta de dados existentes, definição de áreas com evidências de contaminação e a etapa de investigação com o objetivo de confirmar ou não a existência de contaminação em uma determinada área.

A opção de se utilizar a metodologia para desenvolvimento desse estudo recaiu sobre a metodologia desenvolvida pela CETESB (1999) e já testada por GLOEDEN (1999), pois esta apresenta, além das etapas comuns, a inclusão de etapas de priorização, com sistemas de pontuação e uma estrutura mais detalhada do cadastro de áreas contaminadas, ou seja, melhor estrutura para o de registro das informações coletadas no processo de identificação de áreas contaminadas. Além disso, esta metodologia foi homologada, pela Diretoria Plena da CETESB, no ano de 2000, como norma interna intitulada: "Procedimentos Para Gerenciamento de Áreas Contaminadas".

A metodologia desenvolvida por IHOBE (1998) aplica-se perfeitamente para cenários pontuais, onde é possível aplicar suas fases (exploratória e detalhada) para a recuperação e/ou revitalização de uma área industrial desativada, ou um antigo lixão, já em uma área ativa a aplicação pode ser no âmbito de implantação e verificação de sistemas de gestão ambiental como a norma ISO 14.000 e suas derivações. 


\section{A EXECUÇÃO DO PROCESSO DE IDENTIFICAÇÃO DE ÁREAS CONTAMINADAS.}

O processo de identificação de áreas contaminadas será dividido em: Materiais utilizados no estudo, Definição da região de interesse, Identificação de áreas potencialmente contaminadas, Avaliação preliminar, Priorizações 1 e 2 e a Classificação 1.

5.1 Materiais utilizados no processo de identificação de áreas na região de interesse.

- Cadastro informatizado: O cadastro de áreas contaminadas - CETESB/GTZ utiliza softwares Visual FoxPro (banco de dados) e ReGIS (para o sistema geográfico de informação) como instrumentos técnicos principais de processamento, das fichas cadastrais e dos mapas utilizados. Utilizando uma rede local Windows NT é constituída por nove computadores, uma mesa digitalizadora, um scanner e impressoras e um plotter. A base de informações é o, inventário SILP/CETESB.

- Cadastro físico do Projeto CETESB/GTZ: Fichas cadastrais e mapas topográficos em escala 1:10.000 da EMPLASA.

\subsection{Definição da região de interesse}

A escolha da região de interesse, neste estudo, recaiu sobre a área do município de Ribeirão Pires devido aos seguintes fatores:

- Essa área localiza-se em região importante para a proteção dos recursos hídricos da RMSP, ou seja, está inclusa totalmente em área de proteção de manancial (APM). A área territorial do município de Ribeirão Pires está contida em sua maior parte na bacia hidrográfica do reservatórios Billings, e em porções menores das bacias dos reservatórios Taiçupeba e Guaió, cujas águas são coletadas para abastecimento dos municípios do Grande ABCD, Suzano, Mogi das Cruzes, Poá, Mauá. 
- Esse município possui um parque industrial diversificado, existindo diferentes fontes potenciais de contaminação dos solos e águas subterrâneas e superficiais;

- Essa região está passando por processo de transformação de uso e ocupação dos solos, com a ocorrência de desativação de estabelecimentos comerciais e indústrias;

- Essa região apresenta um volume significativo de informações existentes tanto sobre o meio físico quanto sobre as fontes potenciais de contaminação, com a possibilidade de serem coletadas em diferentes fontes de informações como a CETESB, Prefeitura de Ribeirão Pires e EMPLASA, fato que viabiliza a execução das etapas iniciais do processo de identificação de áreas contaminadas.

\subsubsection{Caracterização do município}

O município de Ribeirão Pires está situado a sudeste da Região Metropolitana da Grande São Paulo e têm como limites políticos os municípios de Santo André, Mauá, Rio Grande da Serra e Suzano.

Ribeirão Pires possui um parque industrial diversificado, as atividades industriais que compõem este cenário possuem junto à CETESB memória técnica para se processar o processo de identificação de áreas contaminadas, possui um conjunto de serviços e atividades comerciais atuantes, passando por processo de transformação de uso e ocupação dos solos e têm fácil acesso rodoviário.

Na figura 5.1 é demonstrado o município de Ribeirão Pires em relação ao seu posicionamento na região metropolitana de São Paulo. 


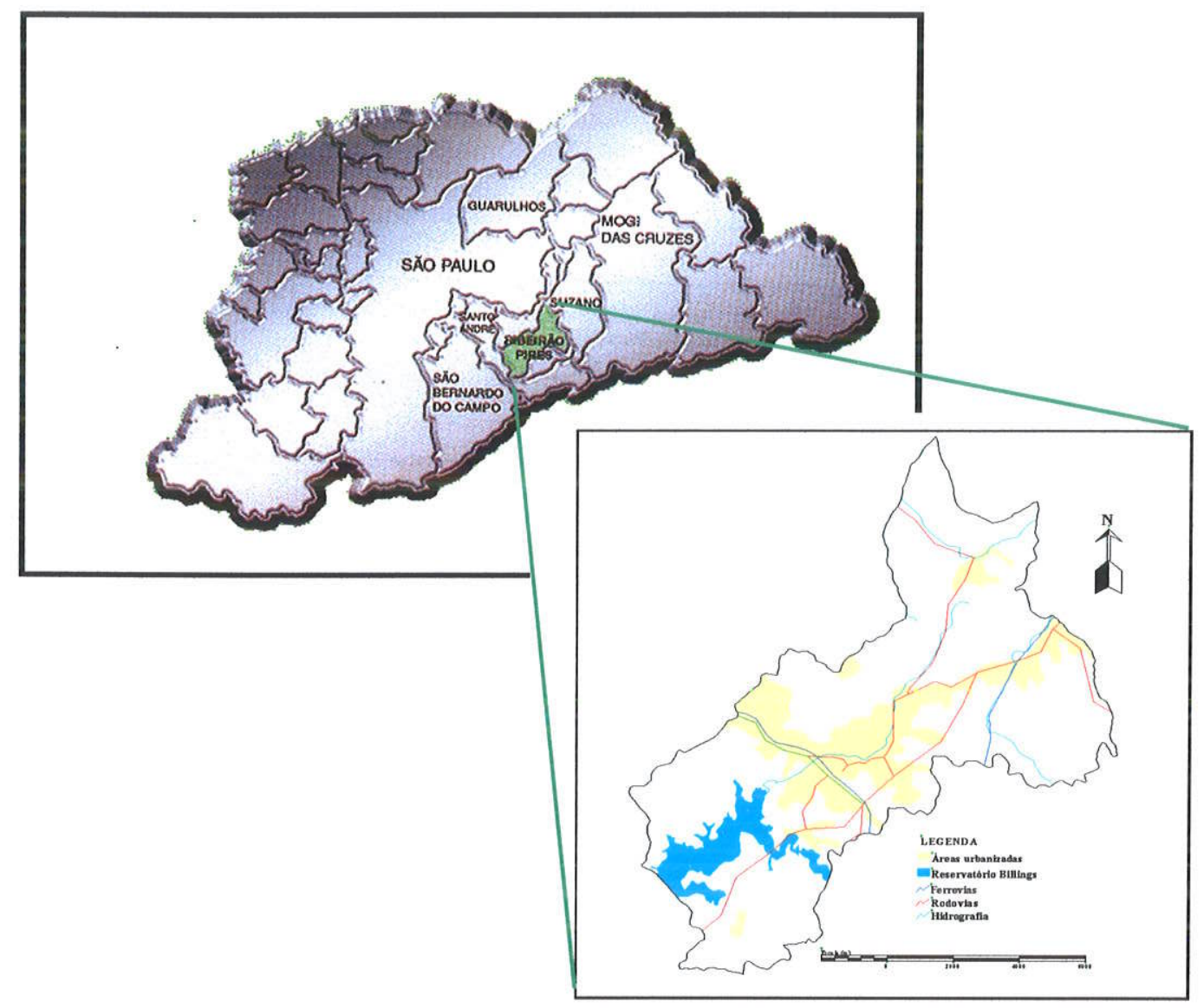

Fonte: EMPLASA (1992) - modificado.

RIBEIRÂO PIRES (site oficial) - modificado.

Figura 5.10 município de Ribeirão Pires

O município localiza-se entre as coordenadas; Latitude Sul 2342' e Longitude Oeste $46^{\circ} 25^{\prime}$. Possui uma área total de $107,0 \mathrm{Km}^{2}$, dividida da seguinte maneira: sede: com $65,5 \mathrm{Km}^{2}$ e distrito de Ouro Fino Paulista com área de $41,5 \mathrm{Km}^{2}$. A altitude máxima é de 1.043 m e a mínima de 747 m (RIBEIRÃO PIRES, 1997).

Quanto à hidrografia destaca-se o ribeirão Pires, que corta o município e que Ihe empresta o nome. Esse ribeirão possui dois afluentes, o córrego Rípoli e o Roncon.

O clima da região é o Tropical de altitude, frio e úmido, com temperatura média anual de $16^{\circ} \mathrm{C}$. O domínio fitoecológico a que pertence é denominado: floresta estacional semidecidual (floresta pluvial tropical ou Mata Atlântica). 
Sua morfologia, segundo AB'SABER (1970), encontra-se inserida no Domínio morfoclimático dos mares de morros, situado na Serra de Paranapiacaba, que por sua vez é um segmento da serra do Mar.

Os ambientes litológicos, apontados por CPRM (1990), são caracterizados pela presença de rochas pertencentes ao Complexo Cristalino de idade Pré-Cambriana com sedimentos da bacia São Paulo e sedimentos Quaternários relacionados às várzeas dos rios atuais.

A descrição estratigráfica pode ser assim representada: do topo à base, uma camada de sedimentos quaternários associados aos aluviões delgados e relativamente extensos, dispostos ao longo das várzeas atuais e aos colúvios.

A camada intermediária é constituída por sedimentos terciários, constituídos por arenitos e pelitos com intercalação de conglomerados correlatos à bacia São Paulo.

A base estratigráfica é formada pelo embasamento cristalino e é representado por: granitos, migmatitos e gnaisses graníticos, mica-xistos e meta arenitos pertencentes ao Complexo Embu.

O sistema aqüifero predominante na área em estudo segue o modelo regional que é o Cristalino, fissurado (de caráter livre a semiconfinado), heterogêneo e descontínuo, na figura 5.2 podem ser observadas a distribuição desses ambientes litológicos. 


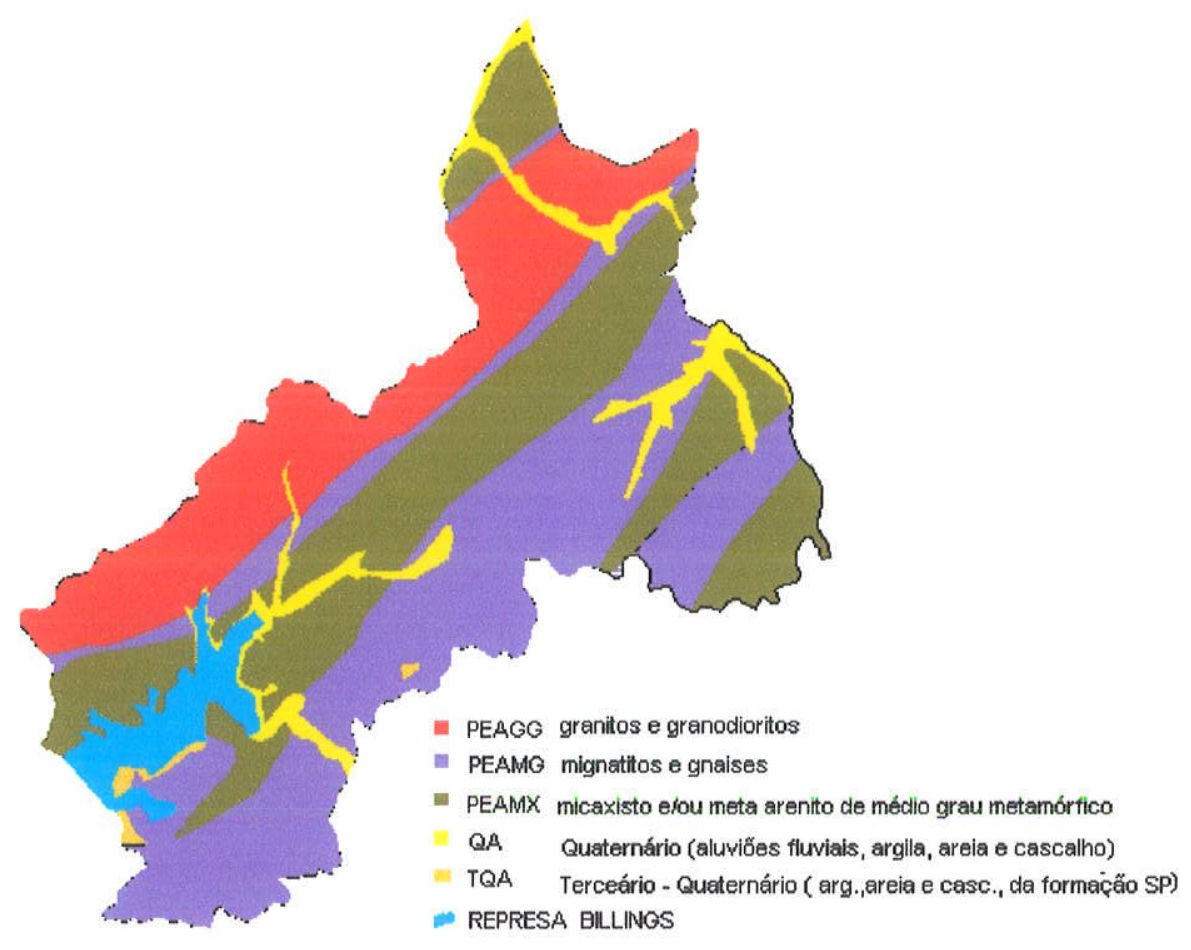

Fonte: EMPLASA (1980) - modificado.

Figura 5.2 Os ambientes litológicos do município de Ribeirão Pires.

O domínio fitoecológico, descrito por AB'SABER (1970), a área do município é denominada pela floresta estacional semidecidual (floresta pluvial tropical ou Mata Atlântica).

Quanto aos dados sócio-econômicos da região de interesse como: população, densidade demográfica, taxa de crescimento populacional, área urbanizada, número de domicílios, de indústrias, de atividades comerciais, de prestadores de serviço, de eleitores e de bairros, serão apresentados no quadro 5.1 . 


\section{Quadro 5.1 Dados sócio-econômicos da região de interesse.}

\section{População}

Área urbanizada

Densidade demográfica

Número de atividades comerciais

Número de bairros

Número de domicilios

Número de eleitores

Número de indústrias

Nümero de prestadores de serviços

Taxa anual de crescimento
100.335 (IBGE, 1996) dado preliminar

$20,2 \mathrm{Km}^{2}$ (EMPLASA - 1996)

953 Habitantes $/ \mathrm{Km}^{2}$ (IBGE 1991)

1.425

25

20.598 (Censo IBGE - 1991)

57762 (Censo BBGE - 1994)

243

505

$3,78 \%$ no período de $1980-1991$

Fonte: RIBEIRÃO PIRES (1997)

Os problemas ambientais que afetam o município, segundo RIBEIRÃO PIRES (1997) são:

- Insuficiência de investimentos em saneamento básico, particularmente nos serviços de coleta, afastamento (dos mananciais) e tratamento de efluentes industriais gerados;

" Poluição dos recursos hídricos, devido ao lançamento "in natura" dos esgotos gerados;

m Inexistência de condições para destinação de resíduos sólidos, atualmente dispostos no aterro sanitário particular do municipio de Mauá (Aterro Sanitário Lara, aterro industrial Boa Hora), representando alto custo.

Pode-se também citar os problemas advindos da edição da Lei Estadual 9.472/96 de dezembro de 1996, que proíbe justamente a instalação de indústrias nas áreas definidas como Segunda Categoria, Classe $C$ - onde tradicionalmente instalaram-se as indústrias no município - e onde são encontradas as maiores áreas vazias da cidade, originando grandes áreas sem usos definidos, vale ressaltar que a lei só permite a instalação de agroindústria, nessa categoria e classe (RIBEIRÃO PIRES, 1997).

Dotado de extensas reservas hídricas e florestais, com $100 \%$ de sua extensão territorial em área de proteção ambiental, possui uma zona rural insignificante o que resultou em um parque industrial limitado pelo manancial, tendo levado a economia 
municipal a ser baseada nas poucas unidades industriais, na atividade comercial e serviços (CANO; CRUZ, in RIBEIRÃO PIRES, 1997).

Por decisão da Assembléia Legislativa do Estado de São Paulo, em 1998, o município foi transformado em Estância Climática, uma aspiração da população desde 1968.

"Muito embora Ribeirão Pires tenha se emancipado em 1953, desmembrando-se de Santo André, sua história remonta ao século XIX, quando se notava, em 1893, um primeiro núcleo colonial com 284 habitantes (entre eles, 173 italianos e 89 brasileiros). A grande afluência de imigrantes nacionais e estrangeiros, em seu território fez sua população crescer a taxas geométricas superiores a diversas cidades do estado. Sua população, que contava com 11.645 habitantes, em 1954, cresce para $21.057 \mathrm{em}$ 1960, mais do que quadruplicou este numero no censo de 1996. A persistência de altas taxas de crescimento populacional em Ribeirão Pires, superiores à região, aponta para maior aglomeração urbana no futuro próximo, certamente com problemas de ocupação racional do solo (comuns a grandes cidades), apesar de não se ter, até então, notícia de significativos adensamentos populacionais em favelas ou invasões urbanas no municipio" (CANO; CRUZ, in RIBEIRÃO PIRES, 1997).

O movimento de industrialização no município se deu lentamente, a partir do final dos anos 70 , quando empresas de pequeno e médio porte, com estreita relação de dependência e complementaridade com o $A B C$ e Região Metropolitana de São Paulo, ingressaram no município, atraídas não só pela proximidade com o $A B C$ - 0 que thes garantia baixos custos de transporte e mão-de-obra especializada - mas também pela existência de um sistema de transporte de passageiros que poderia garantir fácil acesso da força de trabalho às unidades de produção.

"Por outro lado, o baixo preço dos terrenos e alguns incentivos municipais - sem que houvesse ai preocupação maior com o fato de localizar plantas industriais em áreas de proteção aos mananciais - foram fatores importantes na decisão locacional daqueles empreendimentos" (CANO; CRUZ, 1997). 
"A maior parte dessas empresas instalou-se na regiâo entre 1972 e 1974, tendo sido determinante a campanha feita na época pela prefeitura de Ribeirão Pires, oferecendo incentivos como terraplanagem, telefones, isenção de imposto territorial e energia" (CÂMARA TÉCNICA INDÚSTRIA - CTI, Comissão Especial de Proteção aos Mananciais - CePM-BILLINGS, 1998).

Segundo a CTI (1998), "A maior parte dessas empresas foi fixar-se em Ribeirão Pires por transbordamento, pois Santo André, São Bernardo e São Caetano, embora apresentando infra-estrutura adequada, já tinham mais alto o valor da terra".

"A "terra barata", pelo menos mais do que em São Caetano, conforme depoimento dos entrevistados, tornou a região extremamente atrativa, ainda mais quando se somam os outros fatores apresentados e que foram estratégicos para a escolha do local. Os mais citados são, portanto a quantidade e o preço da terra, a excelente rede de transporte (ferrovias, rodovias e o porto de Santos), a proximidade com os fornecedores e o mercado consumidor - especialmente as montadoras do $A B C$ - e a existência da indústria Solvay que sediada na região desde 1946, funcionou como pólo de atração de indústrias químicas, oferecendo insumos para a produção" (CTI, 1998).

Outros fatores apontados pela CTI (1998) como água abundante, a posse antiga da terra e até o microclima local, foram também citados como estratégicos para atração das indústrias ao município.

A implantação de grandes projetos no setor de montagem de automóveis, metalurgia, autopeças, mecânica, borracha e química que haviam se instalado na região do $A B C$, no Programa de Metas, de desenvolvimento do pólo industrial, no período de 1956 a 1960, gerou estímulos para a ampliação das relações entre os setores industriais (fornecedor-cliente), entre todos os municipios.

Em 1976, é aprovada a Lei Estadual de Proteção aos Mananciais, que transformou todo o território municipal em área de interesse para a manutenção dos recursos hídricos, necessários ao abastecimento da região metropolitana. Este instrumento 
visa garantir a qualidade das águas, através - principalmente - da ocupação pouco intensiva do solo, vinculada a baixos limites de densidade.

\subsubsection{Objetivos do gerenciamento de áreas contaminadas em Ribeirão Pires}

Uma vez apresentada a descrição das características da região de interesse: Ribeirão Pires, nota-se claramente que há a necessidade de um planejamento efetivo do uso e ocupação dos solos da região, para que se possa garantir a qualidade aos bens a proteger, como as águas superficiais e subterrâneas, a qualidade dos solos e a saúde da população. O conhecimento das áreas onde foram e são desenvolvidas atividades potencialmente contaminadoras aos bens a proteger devem ser identificadas, avaliadas, quali e quantitativamente e cadastradas.

As novas formas de utilização do solo devem ser definidas em função das condições ambientais existentes, das propostas de melhorias destas condições ambientais e obedecer à nova Lei de Proteção dos Mananciais.

\subsection{Identificação de áreas potencialmente contaminadas (APCs)}

A base de dados utilizada nesse estudo para a identificação de áreas potencialmente contaminadas é o cadastro de informações da CETESB denominado SIPOL, onde são registradas todas as informações referentes ao licenciamento de atividades $e$ aplicação de penalidades no Estado de São Paulo. A existência dos processos de licenciamento de instalação e funcionamento de empreendimentos é resultado da aplicação da lei número 997/76, que teve seu regulamento aprovado pelo Decreto 8468 de 08/09/76 e descreve em seus artigos 57 e 58 as atividades industriais e/ou comerciais que são passiveis de licenciamento pela CETESB.

As informações que estão disponiveis nos processos de instalação e funcionamento de um dado empreendimento, segundo SPSMA/CETESB (1998), são:

- Nome e razão social da atividade a ser licenciada,

- Endereço, 
- Atividade principal,

- Código IBGE,

- Tamanho da área; edificada e total,

- Número de funcionários,

- Data de início e final de funcionamento,

- Matérias primas; denominação, quantidade média mensal,

- Relação de produtos: denominação, quantidade média mensal,

- Relação de máquinas e equipamentos; quantidade, capacidade, potência,

- Armazenagem; forma, método, carga e descarga de matérias primas, embalagens, produtos elaborados,

- Fluxograma de produção ou mudança desse,

- Combustiveis utilizados; tipo, quantidade média mensal,

- Abastecimento de água; utilização,

- Despejos líquidos; tratamento, disposição final, origem, estimativa de quantidade, tratamento, disposição final,

- Resíduos sólidos; tipo, estimativa de coleta, tratamento, disposição,

- Croqui de localização; especificação do uso do solo em um raio de aproximadamente 100 (cem) metros, lançamento em cartas de aerolevantamento ou mapas.

Os processos trazem em seu conteúdo aquelas informações que traduzem o passado e o presente das atividades a serem avaliadas, pois as mesmas têm periodicamente a inspeção de controle por parte do corpo técnico da CETESB, onde cada vistoria é anotada em auto de inspeção, cópia desse é anexado junto ao processo, denotando assim um caráter histórico aos eventos, que podem fazer parte do passivo ambiental da área ou atividade em questão.

No processo de identificação de áreas contaminadas, bem como no cadastro e o processo de remediação as fontes de informação, como os processos aqui descritos são fundamentais como alicerce logístico para execução das tarefas do fluxograma do gerenciamento de áreas contaminadas em uma dada região de interesse. 
Os autos de inspeção traduzem a leitura técnica e o acompanhamento do agente CETESB responsável pela área em questão, pois são o instrumento comprobatório da estada desse na referida área e podem conter Informações históricas como acidentes, reclamações, novos equipamentos e outras que podem estar relacionadas com seu passivo ambiental.

A seguir estão relacionados os principais itens da ficha cadastral de áreas contaminadas que podem ser preenchidos: em escritório com o auxillio dos processos (a apresentação será feita de forma similar àquela encontrada na ficha cadastral de áreas contaminadas):
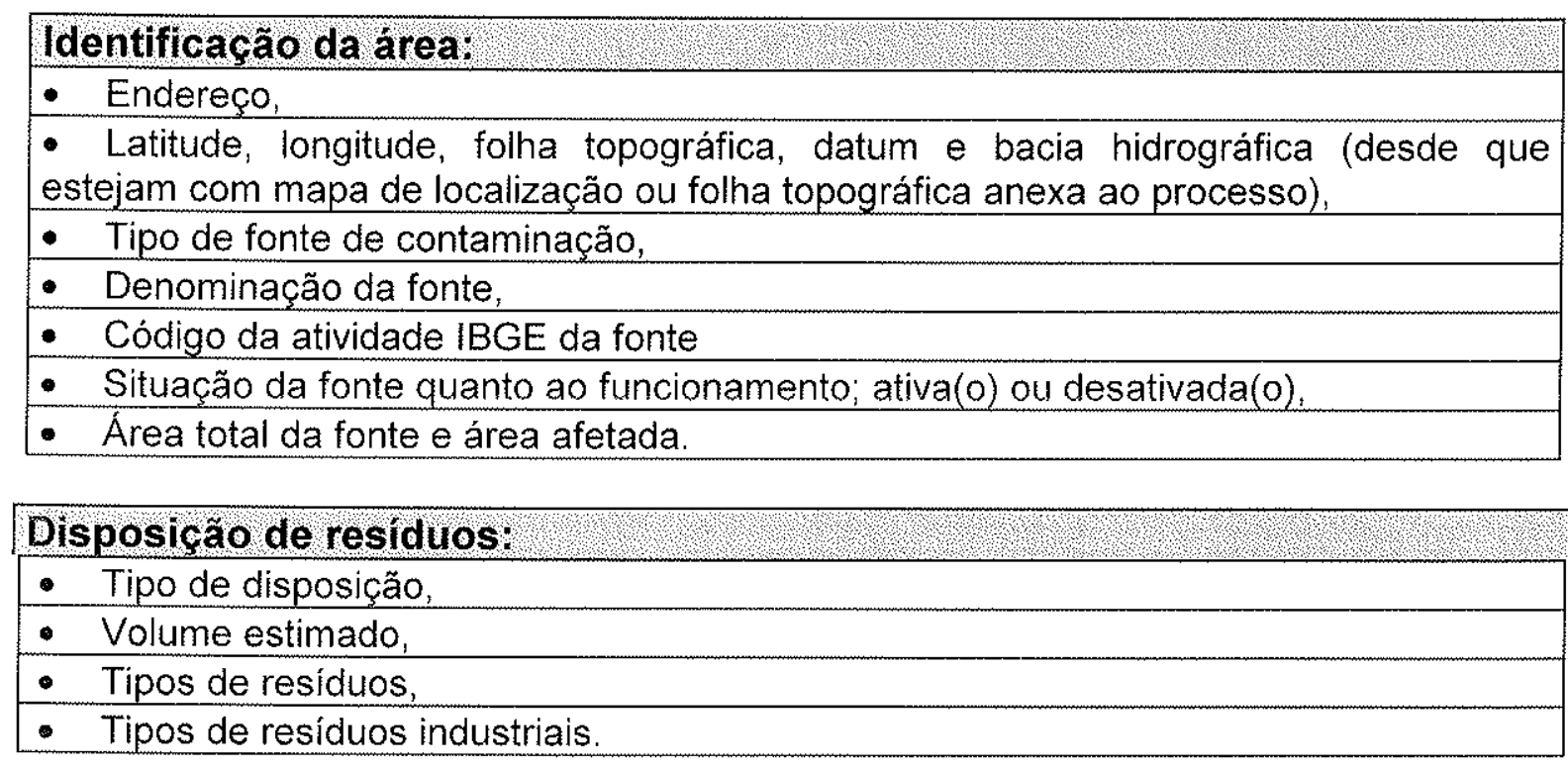

\begin{tabular}{l}
\hline Area industrial/comercial: \\
\hline - Tipo de atividade, \\
\hline - Fonte provável de contaminação, \\
- Número de funcionários \\
- Materiais utilizados/produzidos/armazenados; denominação, tipo de material, \\
quantidade, unidade, armazenamento, \\
destinaçãóo final, \\
- Destino das águas residuárias e o tipo de seu tratamento, \\
\hline
\end{tabular}

\section{Outras fontes:}

- Tipo 


\section{Descrição da área e suas adjacências:}

- Substâncias presentes na área; confirmada, estimada,

- Ocupação do solo/áreas com bem a proteger,

- Uso atual da área,

- Existência anterior de outra fonte potencial de contaminação na área,

- Existência de solo contaminado,

- Existência de água contaminada por influência da área,

- Contexto hidrogeológico da área,

- Resultado de análise de solo,

- Variação do nível da água subterrânea na área,

- Nível sazonalmente mais elevado da água subterrânea,

- Existência de água subterrânea contaminada por influência da área,

- Uso da água subterrânea afetada pela contaminação,

- Existência de água subterrânea contaminada por influência da área (confirmada por análise),

\section{Eventos importantes/existência de riscos:}

- Ocorrência de acidentes e/ou eventos importantes,

\section{Atividades desenvolvidas na area:}

- Investigação confirmatória; executante, data de início, encerramento e resumo dos resultados,

\section{Fontes de informação:}

- Número do processo CETESB,

\section{Xerox do mapa de localização da área.}

- Xerox da localização do polígono que acompanha o processo, carta da EMPLASA RMSP, levantamento aerofotogramétrico, esc. 1:100.000.

Os itens que são contemplados na avaliação de campo são aqueles que não foram preenchidos, devido à necessidade de se averiguar in loco. Como exemplo podemos citar: a razão social e a denominação atual da fonte, pois nem sempre o órgão fiscalizador é notificado dessas mudanças.

Cabe ressaltar que para postos de serviço automotivo não há processo de instalação e funcionamento do estabelecimento, pois essa atividade não é passível de licenciamento. Somente há abertura de um processo na CETESB, quando há denúncia da população em episódios de vazamentos ou acidentes com combustíveis, esses são denominados "processos administrativos". 
Conceitualmente, o potencial de contaminação dos bens a proteger que essas atividades possuem, por se utilizarem de produtos da refinação de petróleo e suas composições denominadas mistas (matéria prima com composição química sintética e mineral, armazenadas, em sua maioria em tanques subterrâneos, que possuem linhas de condução dos produtos às bombas de abastecimento, os bocais de abastecimento desses tanques, como também as águas residuárias de lavagem de piso (pátio). são consideradas como sendo fontes primárias de liberação de contaminantes aos bens a proteger.

\subsubsection{Priorização 1 - Definição das atividades potencialmente contaminadoras.}

Para a definição das atividades potencialmente contaminadoras (APCs), na região de interesse Ribeirão Pires, foi necessário o estabelecimento de critérios para a escolha das atividades industriais e/ou comerciais, as que pudessem gerar impactos aos bens a proteger.

O total de estabelecimentos industriais e/ou comerciais presentes no município relacionados no SIPOL/CETESB são 328 (trezentos e vinte e oito). Esse número compreende o total dos estabelecimentos que obtiveram ou que estão solicitanto licenças de instalação e/ou funcionamento junto à CETESB, mais especificamente, junto à agência ambiental CETESB - Santo André, responsável pelo controle ambiental da região de interesse Ribeirão Pires.

A lista de atividades industriais e/ou comerciais do município de Ribeirão Pires, consideradas atividades potencialmente contaminadoras neste estudo, segundo CETESB (1999) e GLOEDEN (1999), foram aquelas que possuem os códigos de atividades atribuídos pelo Instituto Brasileiro de Geografia e Estatística - IBGE números: $11,12,13,14,18,20,23,50,55,61$ e 99 (2 algarismos inicias que representam o gênero das atividades). A lista dessas atividades pode ser observada no quadro 5.2 . 
Quadro 5.2 Lista das atividades industriais/comerciais potencialmente contaminadoras, utilizando-se a classíficação IBGE

\begin{tabular}{|l|l|}
\hline Código IBGE & Descrição das atividades \\
\hline 11000 00 a 1199999 & Metalúrgica \\
\hline 1200000 a 1299999 & Mecânica \\
\hline 1300000 a 1399999 & Material elétrico e de comunicações \\
\hline 1400000 a 1499999 & Material (veiculos) de transporte \\
\hline 1610000 a 1619999 & Fabricação de móveis; madeira, vime \\
\hline 1620000 a 1629999 & Fabricação de móveis de metal \\
\hline 1800000 a 1899999 & Borracha \\
\hline 2000000 a 2099999 & Química \\
\hline 2300000 a 2399999 & Produtos de matérias plásticas \\
\hline 5030000 a 5039999 & Transportes rodoviários \\
\hline 5599000 a 5599999 & Serviços de conservação \\
\hline 6109000 a 6110999 & Comércio varejista de combustiveis \\
\hline 9999000 a 9999999 & Disposição de resíduos \\
\hline
\end{tabular}

Fonte: CETESB, 1999

A retirada de processos da agência Ambiental Santo André, foi executada em 6 (seis) etapas. O pedido dos processos na agência Santo André, foi efetuada por envio de fax-símiles e os mesmos foram retirados pessoalmente ou enviados à sede CETESB, via malote interno.

A etapa seguinte é aquela que se pode definir como: etapa de preenchimento das fichas cadastrais, ou o estudo histórico propriamente dito. Atividade predominantemente de escritório, é quando se deve atentar para a descrição do histórico da área, no que tange ao entendimento do processo industrial / comercial em questão, bem como efetuar o exame das cópias dos autos de inspeção (instrumento que atesta a vistoria por parte do técnico CETESB a uma dada área).

Os autos de inspeção são parte integrante de todos os episódios que envolvem os processos de licenciamento e ocorrências ambientais de uma APC.

\subsubsection{Registro das áreas potencialmente contaminadas (APS) em Ribeirão Pires}

Uma vez definidas as atividades potencialmente contaminadoras (APCs), partiu-se para a identificação das áreas onde estas atividades foram ou são desenvolvidas, utilizando-se o cadastro da CETESB que são as denominadas áreas potencialmente contaminadas (APs). 
Como resultado desta ação foram obtidos os seguintes números: dos 328 registros de atividades industriais e comerciais listados, foram eliminados 217 (duzentos e dezessete), considerando que nessas áreas não são ou foram desenvolvidas atividades potencialmente contaminadoras, restando, desta forma, 109 (cento e nove) áreas, que foram consideradas áreas potencialmente contaminadas (APs), sendo divididas da seguinte forma:

- 90 (noventa) áreas industriais e/ou comerciais,

- 17 (desesete) postos de serviço automotivo,

- 01 (um) área de disposição de resíduos desativada e

- 01 (um) cemitério.

\subsection{Avaliação preliminar}

Conforme metodologia descrita no item 4.1.4, para a execução da etapa de avaliação preliminar devem ser conduzidas duas tarefas, denominadas: coleta de dados existentes e inspeção de reconhecimento da área.

\subsubsection{Coleta de dados existentes}

Com o objetivo de se efetuar um estudo histórico das APs identificadas na etapa anterior foram utilizadas as seguintes ferramentas: mapas EMPLASA (1992) com a localização das áreas potencialmente contaminadas identificadas, CADASTRO CETESB/GTZ (banco de dados local), representado pela ficha cadastral de áreas contaminadas, que é a base de orientação para o registro de dados sobre as áreas. A principal fonte de informação utilizada foram os processos de licenciamento das áreas potencialmente contaminadas levantados na agência ambiental de Santo André/CETESB.

\subsubsection{As Inspeções de reconhecimento das áreas potencialmente contaminadas}

Por opção do autor a descrição de produtos que nos processos de licenciamento tiveram uma maior citação, devido à priorização das atividades executadas no 
processo de identificação em curso, se dará nesse item. As descrições serão ampliadas não só no sentido específico da substância, mas em relação a sua obtenção, aplicação, composição e propriedades que desempenham nos processos industriais e/ou comerciais. ${ }^{3}$

Merece especial menção o termo lubrificante que segundo NEIVA (1993), pode ser definido como o agente capaz de efetuar a diminuição de atrito entre duas peças, que estejam efetuando trabalho em regime de "contato intimo", evitando o desgaste, aquecimento e protegendo-as contra possiveis contaminações, como salienta lorga. A redução do atrito em superfícies, metálicas ou não, que estão em movimento é conseguida pela manutenção de um filme de lubrificante. Tal filme, em geral é constituido por óleos e/ou graxas. Esta propriedade recebe o nome de lubrificação hidrodinâmica. A seguir serão descritos os termos e a tipologia dos principais lubrificantes.

Óleos: Os principais tipos de óleos que foram identificados nos processos industriais avaliados foram:

Óleos anticorrosivos / protetivos: Podemos definir que corrosão é a ação química e/ou eletroquímica resultante da ação que o meio ambiente exerce sobre os materiais metálicos. Os óleos anticorrosivos e protetivos têm como função básica abrandar ou extinguir tal ação. A seguir, serão definidos os termos óleos anticorrosivos e os protetivos.

Anticorrosivos: são óleos temporários compostos basicamente por óleo mineral básico e aditivo. Os aditivos podem ser minerais (óleos minerais, sais metálicos de petróleo, silicone), vegetais (cêras, óleos essênciais), animais (lanolina), ácidos (ácido sulfônico), sabões metálicos e hidrazinas, que são empregados para a proteção de materiais metálicos com a finalidade de se evitar corrosão. $O$ aditivo anticorrosivo mais utilizado comercialmente, em lubrificantes industriais e/ou automotivos, é o dialquil ditiofosfato de zinco.

\footnotetext{
${ }^{3}$ As informações técnicas foram, prestadas pelo. químico responsável da IORGA, óleos e protetivos industriais Ltda, Quim. Inoue, Shizuo. (comunicaşão oral).
} 
O termo temporário, não é aplicado em relação à duração da eficiência de proteção, mas sim à facilidade que o material protegido retorna às condições originais. Quer seja pela utilização de desengraxantes para a retirada do filme protetivo ou pela remoção da pelicula anticorrosiva por descascamento.

Os óleos denominados como protetivos são aqueles que emprestam aos metais, propriedades que assegurem a estes condições de acabamento pré-determinadas. Basicamente os óleos protetivos são compostos por:

a) Óleo mineral básico, hidrocarboneto parafínico ( $10 \%$ do total da composição),

b) Petrolatos (fração de resíduos finos do petróleo) e/ou lanolina (respondem por $10 \%$ do total) e

c) Solventes como a nafta, a aguarrás $\left(\mathrm{C}_{6}-\mathrm{C}_{9}\right)$, o querosene ou a benzina $\left(\mathrm{C}_{6} \mathrm{H}_{14}\right)$ (respondem por $80 \%$ da formulação).

Óleo para estampagem: A estampagem pode ser definida como a ação que uma dada ferramenta impõe sobre ou sob uma chapa metálica, emprestando a essa: forma, corte, dobra ou repuxo.

Os óleos de estampagem são compostos por óleos lubrificantes que quando de sua aplicação sobre chapas de aço, devem apresentar determinadas características, como forte adesão, alta capacidade de lubrificação e ainda não interferir em outros processos como solda e pintura. Eventualmente são utilizados óleos minerais de alta viscosidade (atrito interno do fluído) ou lubrificantes sólidos para estampagens que apresentam altas cargas pontuais. Os óleos para estampagem também podem ser utilizados para operações de corte, dobra e repuxo de metais ferrosos ou não ferrosos.

Em geral as composições desses óleos são mistas, ou seja, são compostas por fluido de petróleo de origem parafínica e de aditivos. Os aditivos são os responsáveis pelas características de desempenho, durabilidade e propriedades de acabamento que esses óleos terão. Há que se destacar que em determinadas indústrias de autopeças, 
um mesmo óleo pode ser utilizado em múltiplas funções, pois esse pode ser utilizado no estampo de peças e também em operações de dobra, corte, repuxo e lubrificação de chapas de aço.

Óleo para eletroerosão: O processo de eletroerosão pode ser classificado como um processo de usinagem térmico (técnicas de trabalho com peças que não utilizam ferramenta), pois em comparação com o sistema convencional as operações de corte e acabamento podem ser feitas pelo mesmo equipamento.

Os óleos para eletroerosão são produzidos por frações especificas da destilação do petróleo, pois essas possuem a capacidade físico/química de efetuar o isolamento dos eletrodos (positivo e negativo) do equipamento e ao mesmo tempo possuem a capacidade de transportar um arco voltáico desses para a peça.

Óleo de corte: Os óleos de corte são soluções químicas que contém sais orgânicos e/ou inorgânicos dissolvidos em água, agentes umectantes, lubrificantes sintéticos e aditivos que suportam extremas pressões.

Suas principais características são: possuir o caráter de detergente, de líquido refrigerador e de resistência à formação de colônias de bactérias. Suas principais funções são: serem desenvolvidos para ter um caráter dedicado à função prédeterminada e apresentar estabilidade na solução quando utilizados sob condições adversas, como por exemplo em ambiente com dureza de água elevada.

Óleo para têmpera de metais: A importância da utilização de óleos para têmpera é a de produzir a um dado material a maior dureza possivel, em um menor tempo. Os óleos mais utilizados em têmpera são os minerais de base parafínica com a adição de aditivos.

Óleo hidráulico: Os óleos hidráulicos são normalmente de origem mineral parafínica e contém aditivos antioxidantes, antiespumantes, anticorrosivos e demulsificantes (abrandadores), são utilizados para a lubrificação de mancais, de rolamentos, caixas 
de engrenagens e máquinas operatrizes. O dialquil ditiofosfato de zinco, também pode ser apontado como o principal aditivo deste grupo.

Óleo lubrificante: Os óleos lubrificantes em geral são de origem parafínica e são aditivados com compostos que emprestam a esses as qualidades de adesividade $\mathrm{e}$ de especificidade.

Esses são formulados para que possam atender às características de lubrificação em motores à explosão (gasolina e diesel), caixas de engrenagens e redutores industriais, podem também ser utilizados na lubrificação de mancais, rolamentos, eixos, etc. Os aditivos que podem estar associados a esses são os que suportam extrema pressão, com características antioxidantes, antiespumantes, anticorrosivas e que contenham substâncias compatíveis com os materiais de vedação, como silicone, cobre e juntas de papelão.

Os óleos lubrificantes podem possuir um caráter dedicado, como os que são utilizados em refrigeração e compressores de ar de precisão, as características que conferem a esses as qualidades específicas são dadas pelos aditivos.

Óleo solúvel: Os óleos solúveis ou aquosos são utilizados em funções de acabamento e corte das peças que requerem precisão de acabamento. Esses óleos são utilizados em tornos e frezas e têm como composição básica, a seguinte mistura: óleo mineral básico, produtos denominados emulgadores (agentes que propiciam a emulsão) como o oleato de trietanolamina (álcalis do grupo amina) ou os sabões, antiespumantes como o silicone.

Aditivos antioxidantes / emulsificantes / detergentes / bactericidas, presentes nos diferentes tipos de óleos: Os antioxidantes mais comumentes utilizados nos óleos lubrificantes são o acetaldeído, a $\beta$-naftalamina, o creosol, o dialquil ditiofosfato de zinco, a hidrazina e a hidroquinona. 
Os emulsificantes, que são substâncias utilizadas em óleos lubrificantes para diminuir a tensão superficial entre dois líquidos, mais utilizados são a etanolamina, o etil benzeno e a n-butilamina.

Os detergentes mais comuns observados em formulações de óleos lubrificantes são a etanolamina e o benzeno.

Os bactericidas incorporados aos óleos de corte aquosos, com o objetivo de controlar e minimizar o crescimento bacteriano em instalações industriais são o percloroetileno e o clorofórmio.

Vale salientar que essas substâncias podem ser encontradas em um só tipo de óleo, podendo estar associadas ao caráter dedicado que esse óleo irá empreender em relação à atividade metalúrgica designada.

Graxas:As graxas em geral são produzidas por misturas homogêneas de óleos lubrificantes e sabões provenientes da saponificação dos ácidos graxos do sebo e de outras gorduras, aditivados com hidróxidos de cálcio, lítio e outros metais (NEIVA, 1993).

Quanto à descrição e definição dos materiais utilizados, produzidos e armazenados relatados nos processos de licenciamento que são utilizados no tratamento de superfícies metálicas, nas áreas de código IBGE 11 (metalúrgicas), um dos processos comumente mencionados são os denominados "tratamentos de superfícies metálicas".

As superfícies metálicas, segundo CETESB NT16, recebem três tipos básicos de tratamento: o desengraxe, a decapagem e o polimento. 


\section{Polimento}

Técnica na qual uma peça é submetida ao alisamento de sua superfície com o intúito de fazer desaparecer as irregularidades, asperezas e bolhas. O polimento pode ser mecânico (via material abrasivo, como pedra pomes, esmeril), eletrolítico (ácido + ácido) ou químico (Imersão das peças em meio ácido).

\section{Desengraxe}

Técnica que consiste em eliminar óleos e graxas da superfície das peças, eventualmente também é efetuado desengraxe de peças após o polimento. $\mathrm{O}$ desengraxe é executado por solventes (elementos desengraxantes) e podem ser: via solventes orgânicos (halogenados ou não halogenados), por intermédio de detergentes, soluções alcalinas, eletrólitos ou umectantes.

\section{$>$ Decapagem}

Técnica que tem por objetivo eliminar os óxidos formados nas superfícies metálicas a sertem recobertas, com o emprego de ácidos.

Cabe também a descrição e definição dos materiais utilizados, produzidos $e$ armazenados, relatados nos processos de licenciamento, nas APCs que produzem plásticos (atividades do código IBGE 23).

O plástico, segundo SHEREVE (1980), pode ser definido como um material que contém uma substância orgânica polimerizada de grande massa molecular que é sólida no seu estágio terminal e em uma certa etapa de sua fabricação, ou de seu processamento, pode ser moldada ou conformada, no produto acabado por meio de um processo de "fluxo".

Há duas grandes classes de plásticos: os termoplásticos e os termoestáveis.

Termoestáveis, são plásticos compostos por soluções "multipartes" (uma resina mais um endurecedor), que após a cura transformam-se num produto praticamente infundivel e insolúvel. São representantes desse grupo os policarbonatos, os poliésteres, os poliuretanos, as poliamidas e as resinas de silicone e as epóxis. 
Os plásticos, denominados termoplásticos, como o polietileno ou estireno são aqueles que na presença de calor sofrem o fenômeno de amolecimento, podendo ser moldados, extrusados (prensar e expulsar) ou fundidos. Os termoplásticos mais citados foram o ABS (estireno butadieno acrilonitrilo), o acrílico, o acetato de celulose e a etil-celulose; os fluoroplásticos, foram o naylon, os policarbonatos, o poliéster, o polietileno, a poliamida, o polipropileno, o poliestireno, o poliuretano e suas espumas (diisocianato de tolueno) e o PVC (poli-cloreto de vinila).

Os grupos de resinas mais citados foram:

- Termoestáveis, que são subdivididas em fenólicas como a marca Fórmica e o baquelite; amínicas que são formadas por uréia-formaldeído; as resinas epóxi que aparecem como marca Araldite; resinas de silicone como Dow Corning e alquídicas como o Rezyl e o Dulux,

- Termoplásticas como o nitrato de celulose,

- Poliméricas como os acrilatos representados pelo o Acryioid, as resinas vinílicas (poli) como o PVA e as resinas de estireno como Styron, poliamidas como o náilon, poliésteres como o poliformaldeídos e poliglicóis (Poliol), outras como as de polietileno como o Petrothene e as compostas por fluorcarbonos como o Teflon e

- Resinas naturais como a goma-laca e a lignina.

$\mathrm{Na}$ identificação da potencialidade de contaminação de águas subterrâneas por materiais plásticos e produtos que os compõem, GLOEDEN (1999) citando USEPA 1994 descreve que podem ser contaminantes desse bem, os solventes presentes no processo de obtenção, os compostos orgânicos e inorgânicos (fenóis, resinas), os cianetos, os formaldeídos, os ácidos, as bases e os surfactantes.

\subsubsection{As tabelas de atividades e substâncias.}

Em suas conclusões GLOEDEN (1999) destaca a necessidade do aperfeiçoamento das listas de atividades potencialmente contaminadoras dos solos e águas subterrâneas. 
Tal necessidade aliada a complexidade dos processos industriais e/ou comerciais envolvidos neste estudo, visando o correto preenchimento da ficha cadastral em seu item 5.1, "Substâncias presentes na área", foram desenvolvidas as "Tabelas de atividades e substâncias" para cada atividade industrial / comercial priorizada.

Essas tabelas foram desenvolvidas, baseadas nas que foram elaboradas na Alemanha, por um projeto do Ministerium für Umwelt, Raumordnung und Landwirtschaft (MURL) do estado de Nordrhein-Wesfalen no ano de 1993.

As atividades foram classificadas segundo suas características de processos industriais / comerciais, de suas substâncias e o potencial de dano que essas possam exercer aos bens a proteger, bem como o histórico que essas atividades apresentam em relação ao manuseio, armazenagem, disposição inadequada de matérias primas, produtos produzidos, resíduos gerados, acidentes e vazamentos naquele país.

As atividades classificadas pelo MURL e priorizadas neste estudo foram agrupados em uma tabela no formato Excell, plataforma Windows, gerada com o auxílio do programa computacional para avaliação de áreas contaminadas denominado ALTLASTENEXPLORER (1997).

Como resultado foi obtida uma "matriz" de configuração: 26 (vinte e seis) colunas, (denominadas atividades), por 123 (cento e vinte e três) linhas (denominadas: substâncias).

Obedecendo a Priorização 1 , as tabelas foram nomeadas seguindo a nomenclatura das APCs que foram priorizadas nesta etapa.

As tabelas são compostas por quatro colunas e as substâncias são identificadas por: seu nome comum, sua fórmula química, em qual grupo contaminante (segundo lista de substâncias desenvolvida pelo setor Avaliações e Transferência de Tecnologia (EETI) - CETESB (no prelo)) estão incluídas e na atividade, como são utilizadas. 
Vale ressaltar que diferentemente das listas de substâncias que são descritas por FETTER (1993) como potencialmente contaminadoras às águas subterrâneas, onde somente os grupos químicos são descritos, ou no caso de EPA-Bro (2000), que sugere a ocorrência de possiveis substâncias de uma atividade industrial e/ou comercial desativada para efeito de investigação confirmatória, essas tabelas podem ser utilizadas para se priorizar ações no gerenciamento de áreas contaminadas.

A seguir, no quadro 5.3, a atividade priorizada que recebeu a denominação: "Lavarápido de veículos", pode ser observada. Todas as demais tabelas de atividades que foram desenvolvidas neste estudo estão no anexo II.

Quadro 5.3 Atividade: Lava rápido de veículos.

\begin{tabular}{|c|c|c|c|}
\hline \multicolumn{4}{|c|}{ Lava rápido de veículos } \\
\hline Substância & Gr.Contaminante & Fórmula & Uso \\
\hline Benzina & Derivado Petroleo & $\mathrm{C}_{6} \mathrm{H}_{14}$ & Solvente \\
\hline Creosol & Fenol & $\mathrm{CH}_{3} \mathrm{C}_{6} \mathrm{H}_{4} \mathrm{OH}$ & $\begin{array}{l}\text { Desinfetante, } \\
\text { surfactante. }\end{array}$ \\
\hline Diclorometano & Solv. Org. Hal. & $\mathrm{CH}_{2} \mathrm{Cl}_{2}$ & $\begin{array}{c}\text { Solvente, } \\
\text { desengraxante. }\end{array}$ \\
\hline Percloroetileno & Solv. Org. Hal. & $\mathrm{Cl}_{2}: \mathrm{CCl}_{2}$ & Solvente \\
\hline Querosene & Derivado Petroleo & & Solvente \\
\hline Tetraclorometano & Solv. Org. Hal. & $\mathrm{CCl}_{4}$ & $\begin{array}{c}\text { Solvente, } \\
\text { desengraxante. }\end{array}$ \\
\hline Tricloroetano & Solv. Org. Hal. & $\mathrm{CHCl}_{2} \mathrm{CH}_{2} \mathrm{Cl}$ & $\begin{array}{c}\text { Solvente, } \\
\text { desengraxante. }\end{array}$ \\
\hline Tricloroetileno & Solv. Org. Hal. & $\mathrm{CHCl:CCl} 2$ & $\begin{array}{l}\text { Limpeza a seco, } \\
\text { desengraxante. }\end{array}$ \\
\hline
\end{tabular}

\subsubsection{Inspeção de reconhecimento}

Nesta etapa serão traduzidas as impressões do técnico nas inspeções de campo, com a utilização das fichas cadastrais de áreas contaminadas. As fichas cadastrais quando levadas a campo possuiam alguns campos já preenchidos, por intermédio da utilização de informações provenientes dos processos de licenciamento CETESB, (vide item 5.3). 
5.4.3.1 Inspeção de reconhecimento: áreas comerciais

As áreas comerciais avaliadas em campo, por meio das fichas cadastrais e com posterior lançamento no cadastro de áreas contaminadas, totalizaram 12 (doze) APs. Para registro no cadastro de áreas contaminadas do Projeto CETESB/GTZ, foram atribuídas a essas os códigos de identificação, alfanuméricos (numeração acrescida de um " $\mathrm{C}$ ", que indica o tipo de fonte de contaminação: Área Comercial).

Foram inspecionadas as seguintes áreas com seus respectivos códigos: C000327, C000335, C000351, C000355, C000378, C000379, C000386, C000387, C000389, C000390, C000391 e a base de armazenamento de combustível, C000232. Este último registro não constava na lista inicial de áreas potencialmente contaminadas, sendo inclusa após denúncia e inspeção de campo.

A atividade de se armazenar produtos químicos e combustiveis, em $85 \%$ (oitenta e cinco por cento) dessas áreas inspecionadas foi apontada, na ficha cadastral, como a atividade que as qualifica como potencialmente contaminadora aos bens a proteger.

Foi constatado que em $70 \%$ (setenta por cento) das áreas destinadas ao armazenamento de substâncias, a impermeabilização do solo é de paralelepídedo ou bloquete (pisos articulados), nos 30\% (trinta por cento) restantes a cobertura é de asfalto/cimento. Vale ressaltar que a área de 0000355 é composta por três tipos de impermeabilização que são: paralelepipedo 60\% (sessenta por cento), 10\% (dez por cento) asfalto/cimento e $30 \%$ (trinta por cento) composto por terra batida com cobertura de pedra britada.

Excetuando-se C000327, C000335 e C000387, todas as demais APs utilizam óleo diesel, como substância armazenada em suas dependências, em tanques de aço, aéreos ou enterrados em um total de 14 (quatorze tanques), sendo desse total quatro unidades enterradas (C000355) e os demais aéreos, a capacidade de cada tanque é de $15.000 \mathrm{~L}$ perfazendo um total estocado de $210.000 \mathrm{~L}$ de óleo diesel. 
Todas as áreas utilizam óleo lubrificante para motores e graxa para lubrificação, ambos acondicionados em tambores metálicos de $200 \mathrm{~L}$, exceto C000355 que utiliza um tanque aéreo (sem contençâo) de $15.000 \mathrm{~L}$ para óleo lubrificante utilizado como óleo lubrificante de motores.

Foi observado que em todas as áreas comerciais, de transporte coletivo como as de carga, possuem boxes de lavagem de veículos, sendo a atividade de lavagem é a principal atividade de 000387.

Os valores percentuais de alguns itens das fichas cadastrais dessas áreas são: $60 \%$ (sessenta por cento) têm o destino das águas residuárias descartadas em córregos ou ribeirões (água superficial) e as $40 \%$ (quarenta por cento) restantes descartam-nas em rede de esgoto municipal. Os tipos de sistemas de tratamento das águas residuárias são: caixas de decantação de sólidos que respondem por $80 \%$ (oitenta por cento) do total de áreas e as $20 \%$ (vinte por cento) restantes utilizam o sistema de caixa separadora de água/óleo, mais o de decantação de sólidos.

Todas as áreas de transporte coletivo e a de comércio de veículos, possuem instalações para manutenção (oficina, funilaria e pintura), onde foram confirmadas as seguintes substâncias: óleo diesel, graxa, querosene, gasolina, óleo lubrificante usado, soda cáustica, thinner e tinta para pintura automotiva.

As substâncias confirmadas nas áreas C000351 e C000389 que têm como atividade principal o transporte rodoviário de produtos químicos foram: ácido clorídrico, fosfórico, sulfúrico, nítrico e fluosilícico, álcalis como a soda cáustica, outros produtos como a anidrita (cal ligante Solvay) e o hipoclorito de sódio.

Somente em $\mathrm{C000351}$ há o armazenamento de "ácidos diluídos $-\mathrm{H}_{2} \mathrm{SO}_{4}$ e $\mathrm{HCl}$ " na área. O volume total estocado é de $200.000 \mathrm{~L} / \mathrm{mês}$, armazenados em tanques de fibra de vidro com capacidade média de $2.000 \mathrm{~L}$, que segundo informação do gerente comercial (informação oral), os produtos estocados nesses tanques são sobras que se acumulam no fundo dos tanques dos caminhões que transportam os produtos a granel. $\mathrm{Na}$ área, os produtos são diluídos nos tanques e comercializadas 
posteriormente com terceiros acondicionados em bombonas plásticas de $200 \mathrm{~L}$. Vale ressaltar que quando da inspeção, não foram observadas medidas de contenção, tanto no páteo de manobras quanto na de estocagem.

Foi verificado que junto a bomba de combustivel (que abastece os caminhões com óleo diesel), havia produto in natura, tanto nas paredes junto à bomba e sobre o piso articulado de bloquete de cimento e paralelepípedo.

Em relação à existência de vazamentos ou infiltrações sobre os pisos das áreas comerciais resultaram nas seguintes porcentagens: 18\% (dezoito por cento) das áreas tinham combustivel sobre o piso, $9 \%$ (nove por cento) das áreas que possuem tanques aéreos, foram notados escorrimento de produtos nas paredes desses, em $55 \%$ (cinquenta e cinco por cento) das áreas o item foi apontado como desconhecido nas fichas cadastrais e somente em $\mathbf{0} 000387$ houve a constatação de que no processo produtivo havia a existência de vazamento e/ou infiltração.

Quanto ao posicionamento das APs em relação ao relevo e ao contexto hidrogeológico da região de interesse, foram constatadas que C000378, C000389, C000386, C000351 e C000335 estão localizadas em área de encosta onde o contexto hidrogeológico predominante é o cristalino em área de recarga, as demais áreas comerciais (C000390, C000327, C000355, C000387, C000391 e C000379) localizamse na várzea (no contexto hidrogeológico: Quaternário).

A base de combustivel descrita no primeiro parágrafo foi avaliada após denúncia de sua existência quando da realização de inspeção no campo, pois a mesma não constava no cadastro consultado.

Optou-se por incluí-la no processo de identificação de áreas contaminadas, recebendo o código alfanumérico C000232, código IBGE 60.16.001 (Comércio atacadista de combustiveis e lubrificantes). Em um breve relato, a mesma ocupa uma área aproximada de 8 (oito) hectares, as margens da rodovia Índio Tibiriçá e com estoque de combustível ou materiais armazenados (ítem 3.4 da ficha cadastral) da ordem de: álcool combustivel: 100.000 (cem mil) litros, gasolina: 440.000 
(quatrocentos e quarenta mil) litros e óleo diesel: 15.000 (quinze mil) litros, podendo ser intercambiados outros 50.000 (cinqüenta mil) litros, acondicionados em oito tanques aéreos.

Em relação ao relevo e o contexto hidrogeológico a área encontra-se: em região de encosta (corte e aterro para instalação de tanques) e no Cristalino com manto arenoso em área de recarga, e cobertura vegetal arbórea que denuncia alteração recente como o manacá da serra (Tibouchina mutabilis) e a embaúba (Cecropia peltata). No item 5.1 onde são anotadas as substâncias presentes na área, obtivemos a confirmação dos produtos de refinação de petróleo (gasolina e óleo diesel), como também a presença de álcool combustivel e para se estimar as substâncias que poderiam estar presentes na área, foi utilizada a tabela 3 do anexo II.

Em relação a ocupação do solo, está inserida em área de mata natural, em área de proteção de manancial, ausência de muros de contenção no perímetro dos tanques, piso coberto com brita sobre terra batida, coloração e presença física de contaminante foram notados sob tubulação aérea de combustiveis, sob tanques e escorrimentos de produtos nas paredes dos tanques, que podem denunciar existência de vazamentos. Foram observadas borras oleosas lançadas às margens de um curso d'água que atravessa a propriedade, denunciando a prática de descarte de resíduos provavelmente oriundos da limpeza de tanques de armazenamento aéreos ou dos "fundos de tanque" dos caminhões que transportam os produtos armazenados.

\subsubsection{Inspeção de reconhecimento: postos de serviço}

Na região de interesse Ribeirão Pires foram inspecionadas 18 áreas potenciais, que foram divididas em áreas ativas e desativadas, sendo que para o registro no cadastro de áreas contaminadas todas foram agrupadas sob o código alfanumérico de identificação "P" (tipo de fonte de contaminação: posto de serviço), acrescido do numeral designado pelo banco de dados.

No quadro 5.4 são apresentados todos postos de serviços automotivo inspecionados, com seu código alfanumérico já atribuído pelo cadastro e a bacia hidrográfica a qual 
pertence, além de observações quanto a companhia fornecedora de combustivel (bandeira), bem como se o estabelecimento está ativo ou desativado.

\section{Quadro 5.4 Postos de serviços automotivo em Ribeirão Pires.}

\begin{tabular}{|c|c|c|}
\hline Código & Bacia hidrográfica & Observação \\
\hline P000128 & Alto Tietê Cabeceiras & Ativo, Petrobrás \\
\hline$P 000129$ & Billings & Ativo, Shell \\
\hline$P 000130$ & Alto Tietê Cabeceiras & Ativo, Petrobrás \\
\hline$P 000191$ & Billings & Ativo, Petrobrás \\
\hline$P 000192$ & Billings & Ativo, São Paulo \\
\hline$P 000193$ & Billings & Ativo, Ipiranga \\
\hline$P 000200$ & Billings & Ativo, Petrobrás \\
\hline$P 000201$ & Alto Tietê Cabeceiras & Desativado, \\
\hline$P 000202$ & Billings & Ativo, Petrobrás \\
\hline$P 000203$ & Billings & Ativo, Branca \\
\hline$P 000231$ & Billings & Ativo, Esso \\
\hline$P 000233$ & Billings & Ativo, Esso \\
\hline$P 000234$ & Billings & Ativo, Ipiranga \\
\hline$P 000235$ & Billings & Ativo, Esso \\
\hline$P 000236$ & Billings & Ativo, Texaco \\
\hline$P 000237$ & Billings & Ativo, Petrobrás \\
\hline$P 000238$ & Billings & Ativo, Branca \\
\hline$P 000239$ & Billings & Ativo, Shell \\
\hline
\end{tabular}

A seguir serão descritas em forma percentual as principais constatações da avaliação preliminar dessas APs:

Em 100\% (cem por cento) das áreas avaliadas, foi observado que a fonte provável de contaminação provém da atividade de armazenagem de produtos em tanques de combustivel enterrados e que esses são confeccionados em chapas de aço.

Os totais de tanques de armazenamento, enterrados e aéreos, divididos por tipo de combustivel, são apresentados no quadro 5.5 . 
Quadro 5.5 Total de tanques, volume e tipo de combustivel, presentes nos postos de serviços automotivo no município de Ribeirão Pires.

\begin{tabular}{|c|c|}
\hline $\begin{array}{c}\text { TANQUES AEREOS } \\
\text { Total }=08 \text { tanques } \\
\text { (01 de } 15.000,01 \text { de } 20.000,01 \text { de } 28.000,01 \\
\text { de } 42.000,03 \text { de } 50.000 \text { e } 01 \text { de } 300.000 \mathrm{~L} .) \\
\text { Volume total }=590.000 \mathrm{~L}\end{array}$ & $\begin{array}{c}\text { TANQUES ENTERRADOS } \\
\text { Total }=82 \text { tanques } \\
(78 \text { de } 15.000 \mathrm{~L} \text { e } 04 \text { de } 10.000 \mathrm{~L}) \\
\text { Volume total }=1.210 .000 \mathrm{~L}\end{array}$ \\
\hline Álcool: 02 de $50.000 \mathrm{~L}$ & Álcool: 21 de $15.000 \mathrm{Le} 01$ de $10.000 \mathrm{~L}$ \\
\hline Diesel: 01 de $15.000 \mathrm{~L}$ & Diesel: 21 de $15.000 \mathrm{Le} 01$ de $10.000 \mathrm{~L}$ \\
\hline $\begin{array}{l}\text { Gasolina: } \\
01 \text { de } 300.000,01 \text { de } 42.000,01 \text { de } 28.000,01 \\
\text { de } 20.000 \text { e } 01 \text { de } 15.000 \mathrm{~L}\end{array}$ & $\begin{array}{l}\text { Gasolina: } \\
36 \text { de } 15.000 \mathrm{~L} \text { e } 02 \text { de } 10.000 \mathrm{~L}\end{array}$ \\
\hline
\end{tabular}

Os principais resíduos gerados nos postos de serviço são os óleos lubrificantes usados e as embalagens de produtos. Os óleos são vendidos ou doados para rerefino (executado por terceiros) e as embalagens são dispostas no lixo doméstico de cada estabelecimento.

Foi constado que somente P000128, não oferece o serviço de lavagem, todos os demais postos de serviço oferecem essa atividade, o sistema de tratamento de águas residuárias dessa operação é efetuado por caixas de separação, de material sólido e água, sendo que o destino dessas é a rede de esgoto.

Foram consideradas como ruins, em 95\% (noventa e cinco por cento) das áreas inspecionadas, as condições de impermeabilização. O tipo de impermeabilização mais utilizado, que responde por $72 \%$ (setenta e dois por cento) das áreas é de asfalto/cimento e nas áreas restantes os pisos são executados em bloquetes de cimento ou paralelepípedo.

Cabe ressaltar que o P000201 foi o único estabelecimento desativado avaliado no estudo, quando da inspeção estava sem as bombas de abastecimento foi constatado que no páteo, nos boxes de lavagem e de troca de óleo, havia a presença de resíduos de óleo usado. Em entrevistas com moradores do local (informação oral) constatou-se que as bombas de combustíveis haviam sido removidas e o combustivel que ainda 
restava nos tanques (que continham diesel, gasolina e álcool) foram retirados pela população, seu piso é constituído de asfalto e paralelepípedo .

Em relação à posição das áreas potenciais para com o relevo e o contexto hidrogeológico regional temos: $57,9 \%$ (cinqüenta e sete vírgula nove por cento) dos postos de serviço localizados em áreas de várzea e no contexto hidrogeológico Quaternário e os $42,1 \%$ (quarenta e dois vírgula um por cento) restantes localizam-se em encosta e no contexto hidrogeológico Cristalino com manto arenoso em área de recarga.

\subsubsection{Inspeção de reconhecimento: áreas Industriais.}

As informações pertinentes às inspeções de área em indústrias química e do setor metalúrgico que foram previamente apontadas como potencialmente contaminadoras aos bens a proteger na região de interesse, são aquelas que neste estudo recebem o código alfanumérico "I" mais numeral automático, conferido pelo cadastro.

A fim de se realizar uma análise mais detalhada do universo de observações que as inspeções de campo propiciaram, as indústrias serão divididas em grupos segundo suas atividades IBGE.

O primeiro grupo a ser descrito será o das indústrias químicas pertencentes às atividades com os códigos 20.11 ao 26.93 . O total de indústrias com este perfil é de dezesseis unidades, sendo treze ativas e tres desativadas.

A seguir serão essas indústrias serão detalhadas percentualmente segundo as apontações das fichas cadastrais, quando da realização das inspeções de área.

\section{- Indústrias químicas desativadas}

As indústrias químicas desativadas avaliadas em Ribierão Pires foram: 1000306, 1000340 e 1000354. 
A atividade industrial em 1000306 e 1000354 era a de injeção de peças plásticas, que segundo os MCEs dos processos de licenciamento CETESB, os materiais utilizados eram: os diisocianato de tolueno, poliol poliéster e o cloreto de polivinila.

Em 1000306 eram produzidos gabinetes de computador em moldes, onde se utilizava como solvente o cloreto de metileno e o desmoldante cera de carnaúba. O consumo médio mensal para o isocianato e de poliol era de 800 (oitocentos) $\mathrm{Kg}$, para o cloreto de metileno era de 200 (duzentos) $\mathrm{Kg}$ e para o desmoldante era de 50 (cinqüenta) $\mathrm{Kg}$, para uma produção 1.000 (mil) unidades / mês de gabinetes de computador.

Já em 1000354 os produtos produzidos eram peças plásticas específicas para o fechamento de máquinas. No processo de licenciamento em seu MCE as matérias primas utilizadas eram pigmentos como o cianeto de sódio, o polietileno de alta densidade, parafusos e porcas de latão. As quantidades dos produtos não estavam especificadas nesse processo.

As atividades industriais que fabricam e/ou manipulam materiais plásticos e outros produtos sintéticos, segundo GLOEDEN (1999) citando USEPA, aponta-as como potencialmente contaminadoras de solo e águas subterrâneas onde os contaminantes citados são produtos das formulações como os solventes (não especificados), óleos, compostos orgânicos e inorgânicos (fenóis e resinas), ácidos, álcalis, surfactantes e subprodutos como os resíduos.

A indústria 1000340 pode ser destacada como um marco da industrialização de Ribeirão Pires, com área de 3.600 (três mil e seiscentos) $\mathrm{m}^{2}$ iniciou suas atividades por volta de 1900 (informação oral) e foi desativada em finais de 1996, tinha como atividade principal o beneficiamento e comércio de sal (IBGE 26.93.99-2).

Originalmente essa indústria não constava do SIPOL/CETESB, mas quando da inspeção de área decidiu-se por incluí-la, por sua importância como marco histórico, posicionamento geográfico que se encontra em relação à Represa Billings e a possibilidade de reutilização de suas dependências por outras atividades, pois quando 
da inspeção encontravam-se em processo de venda. As informações históricas foram dadas pelo zelador responsável, do imóvel.

Como matéria prima destacava-se o sal bruto, originário do Rio Grande do Norte, que via porto de Santos era transportado a essa por via férrea (há um ramal ferroviário para transbordo e expedição de produto produzido dentro da área). No processo de beneficiamento do sal, era utilizado o óleo combustivel (óleo baiano) que era queimado nos fornos de secagem e armazenado em tanque aéreo com capacidade para 15.000 (quinze mil) litros. O óleo diesel ou querosene para o aquecimento ou partida para aquecimento do óleo combustível, era manipulado e estocado em barris de 200 (duzentos) litros.

Quando da inspeção de campo, o edifício principal encontrava-se em estado de abandono bem como o galpão de armazenagem de produtos produzidos, foi constatado que houve alguns desmoronamentos de diversas paredes internas deixando parte dos fornos e o tanque de óleo combustível ao relento. Foi verificado que sobre o piso, impermeabilizado com concreto e com inúmeras trincas, havia restos de óleo combustível e graxa.

O tipo de impermeabilização na área externa (incluindo oficinas) é de paralelepípedo, e nas áreas de produção e estoque é de cimento/asfalto.

$\mathrm{Na}$ área que outrora pertenceu a oficina de manutenção, na superficie do solo, há indicações de resíduos de graxas e óleos bem próximas a um poço de abastecimento que ainda hoje é utilizado pela família do zelador. Está posicionada, em relação ao relevo, na várzea e no contexto hidrogeológico Quaternário.

\section{- Indústrias químicas ativas}


As indústrias químicas ativas que em campo foram inspecionadas serão apresentadas em quatro grupos distintos segundo seus códigos de atividades IBGE, são elas:

- Grupo 20.11 é representado pela 1000316 que rerefina óleos usados,

- Grupo 20.12 é representado por 1000314 que produz óleo branco,

- Grupo 20.99.04 é representado por 1000283 que produz emulsificantes e

- Grupo 23 é representado pelas indústrias que fabricam e manipulam plásticos, 1000256, 1000257, 1000319, 1000321, 1000329, 1000341, 1000345, 1000368, 1000372 e 1000399.

Única empresa com processo de investigação confirmatória executado em suas dependências de todo o levantamento, 1000316 representante do Grupo 20.11, é uma empresa que têm como atividade principal o rerefino de óleo lubrificante automotivo, 0 entamboramento de óleo lubrificante novo, óleo de freio, óleo para transformadores e a formulação de graxa.

Fundada em 1959, ocupa uma área total de 84.000 (oitenta e quatro mil) $\mathrm{m}^{2}$, junto a rodovia SP 55.

Para obter a produção mensal de graxa na ordem de 100 (cem) T/mes e de óleos na quantia de 510.000 (quinhentos e dez mil) L/mês), segundo seu processo de licenciamento CETESB, são consumidos: 500.000 (quinhentos mil) litros de óleo mineral básico; 400 (quatrocentos) $\mathrm{m}^{3}$ de óleo lubrificante usado, 10.000 (dez mil) litros de aditivos para óleos e graxas (fosfato tricresil, dialquil ditiofosfato de $\mathrm{Zn}$ ou $\mathrm{Ba}$, petrolatos, grafite, 20 (vinte) $\mathrm{m}^{3} /$ mes de ácido sulfúrico, 6 (seis) T/mes de hidróxido de cálcio, 6 (seis) $\mathrm{m}^{3} / \mathrm{mês}$ de álcool, 1 (um) $\mathrm{m}^{3} /$ mês de óleo de mamona, 16 (dezeseis) $\mathrm{L} /$ mes de oleína vegetal, 20 (vinte) $\mathrm{m}^{3} /$ mes de sebo animal e 8 (oito) T/mes de terra filtrante.

Os volumes de resíduos declarados são de 40 (quarenta) T/mês de borras da produção (ácidas ou neutras). 
O destino das águas residuárias do processo e as de lavagem do piso da fábrica são coletadas por canaletas e enviadas a uma caixa separadora de óleo/água; quanto à impermeabilização da área podemos divididi-la em: impermeabilização da unidade rerefino de óleo, do galpão coberto e da área de manobra e estocagem de produtos acabados.

A impermeabilização das unidades de produção e estoque são: na unidade de rerefino de óleo a céu aberto é de cimento e pedra britada, no galpão coberto (produção e entamboramento de óleos e graxas) é de concreto e na área de estocagem de produtos acabados terra batida.

Quanto a vazamentos e infiltrações de substâncias no solo foi observado que havia no piso junto à torre de rerefino grandes manchas de óleo e poças de produtos (óleos e graxa) no piso, provenientes possivelmente das conecções de tubulações aéreas, do processo produtivo e manutenção dos equipamentos.

Para descrição da área e suas adjacências em um raio estimado em 500 (quinhentos) metros, serão descritas as substâncias presentes, a ocupação que essa ocupa em relação ao solo e aos bens a proteger, a distância que possui em relação a edificação mais próxima, sua posição em relação ao relevo e ao contexto hidrogeológico.

Os grupos contaminantes confirmados na área, segundo os produtos produzidos e/ou utilizados foram: os solventes orgânicos não halogendos, os hidrocarbonetos aromáticos, os produtos da refinação do petróleo e outros como a oleína vegetal e o sebo animal, já os grupos contaminantes estimados foram obtidos utilizando-se da tabela 21 (Fabricação de óleo mineral, industriais, protetivos, dedicados, lubrificantes) do anexo II.

Quanto a ocupação do solo e áreas com bens a proteger, há utilidades como telefone, rede elétrica, mata natural, área de proteção de mananciais, bacia hidrográfica que é utilizada para abastecimento, há aqüiferos importantes e um poço para abastecimento domiciliar/industrial. 
Quanto ao posicionamento de 1000316 em relação ao relêvo da região, encontra-se posicionada no topo/encosta e quanto ao contexto hidrogeológico está no Cristalino com manto arenoso em área de recarga.

Quanto às águas superficiais foi considerada a possibilidade de que a área possa exercer influência de maneira direta sobre essas, quanto à utilização para consumo como também para pesca já que há na propriedade uma represa onde se pratica pesca.

As atividades desenvolvidas por terceiros, em relação ao diagnóstico ambiental da área, tiveram início em janeiro de1997. Segundo informação oral do diretor da empresa houve também a "investigação detalhada" na unidade fabril. O relatório e suas conclusões não estavam disponiveis, quando da inspeção de campo, sendo apresentado somente o contrato firmado entre as partes.

Um outro exemplo de indústria química ativa na região de interesse, com grande representatividade, no processo de identificação devido aos volumes de produtos químicos que produz e ao grande número de reclamações, efetuadas pela população junto à Agência Ambiental Santo André / CETESB, é a representante do Grupo 20.99 .04 codificada como 1000283.

Segundo seu processo de licenciamento, tem como finalidade à produção de polímeros para tratamento de águas potáveis, de efluentes industriais ou de estações de tratamento de esgotos municipais, clarificadores para caldo de cana de açúcar, produtos para tratamento de águas de caldeira e de resfriamento industrial, produtos para floculação e para decantação em indústrias de papel, açúcar e mineração, sílica coloidal utilizada na clarificação de vinho, produtos antiesgarçantes, antiespumantes, produz resinas poliméricas, e em passado recente, recuperava solventes clorados.

Os grupos contaminantes de substâncias confirmadas presentes na foram: o de solventes orgânicos não halogenados e halogenados, o de compostos orgânicos nitrogenados representado pela linha de produção de poliacrilamida (utilizadas como floculante para o tratamento de água), o de produtos da refinação do petróleo 
(querosene, óleo mineral básico, óleo hidráulico) e o grupo contaminante dos ácidos, bases e outros como o Sorbitan que é uma mistura de ésteres, anidridos e ácidos graxos (produto utilizado como emulsificante de mistura).

Devido ao elevado número de matérias primas, envolvidas nos processos, serão apresentadas no quadro 5.6 somente aquelas substâncias cuja quantidade manipulada mensalmente ultrapassa a quantia de uma tonelada / mês.

Quadro 5.6 Matérias primas utilizadas, em uma indústria química ativa que produz materiais para tratamento de efluentes, clarificantes e dispersantes.

\begin{tabular}{|l|c|l|}
\hline \multicolumn{1}{|c|}{ DENOMINACÁO } & QUANTIDADE - TImes & UTILIZACÁO (como matéria prima) \\
\hline Acido acrilico & 1,8 & Poliacrilamida \\
\hline Acrilamida & 15 & Poliacrilamida \\
\hline Água deionizada & 34,8 & Poliacrilamida, Dispersantes \\
\hline Estearina & 2,8 & Antiespumantes \\
\hline Isopropanol & & Dispersantes \\
\hline Mono estereato de Sorbitan & 1,1 & Poliacrilamida \\
\hline Óleo mineral & 35,5 & Antiespumantes \\
\hline Polietileno glicol & & Antiespumantes \\
\hline Polipropileno glicol ftoxilato & 18,0 & Dispersantes \\
\hline Querosene & 16,0 & Antiespumantes, Poliacrilamida \\
\hline Solventes clorados & Não especificada & Dispersantes, Recuperação \\
\hline Sulfito de sódio & 3,9 & Tratamento de água \\
\hline Tripolifosfato de sódio & 2,4 & Tratamento de água \\
\hline Tripolifosfato de sódio & 2,4 & Tratamento de água \\
\hline
\end{tabular}

Fonte: Processo CETESB.

A quantidade de matéria-prima propiciam a produção de antiespumantes na ordem de 50 (cinqüenta) T/mês, as poliacrilamidas (aniônica e catiônica) em um volume de 60 (sessenta) T/mês, dispersantes com um total de 25 (vinte e cinco) T/mês e são produzidas 6,5 (seis e meio) $\mathrm{T} /$ mês de produtos para tratamento de água para abastecimento e para indústrias (caldeiras, torres de resfriamento). 
Os solventes clorados que são citados no quadro acima não foram quantificados ou qualificados no MCE, mas segundo o técnico de segurança da empresa (informaçăo oral) que havia uma unidade de recuperação de solventes usados operando até meados de 1996 (a linha foi transferida para outra unidade da empresa).

$\mathrm{Na}$ relação de produtos produzidos, esses não são citados, mas para efeito de pontuação foram confirmados como substâncias presentes na área. Os solventes clorados aparecem como matéria-prima no fluxograma de produção de dispersantes (vide figura 5.3), mas mesmo esses não foram descritos.

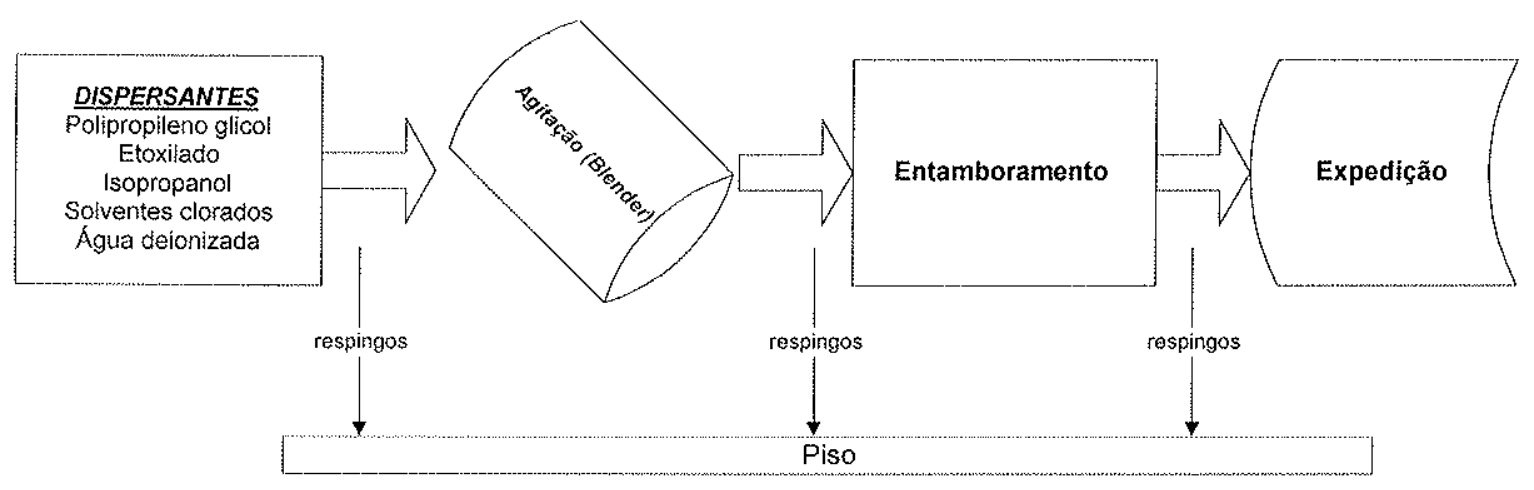

Fonte: Processo CETESB (modificado).

Figura 5.3 Fluxograma de produção de dispersantes, com possíveis liberações de resíduos para o piso da indústria.

Os resíduos sólidos gerados no processo são representados pelas sucatas metálicas (tambores e peças de manutenção) em um volume estimado em 3 (três) T/mes, que são retirados por caçambas e vendidos a terceiros.

Os sistemas para tratamento de águas residuárias são dois: o físico-químico e o de leito de secagem. Ambos recebem águas provenientes da produção e de lavagem de piso as quais são enviadas a uma estação de tratamento própria onde são processadas. Quando da inspeção foi notado que o canal de condução de águas para o tratamento de estava corroído, pois o mesmo é construido em concreto e estava se desfazendo, possivelmente pelo $\mathrm{pH}$ ou pela temperatura dos efluentes gerados. 
As condições de impermeabilização foram consideradas ruins na área de produção, pois foi verificada a existência de inúmeras trincas, a presença de óleos, graxas e resíduos de produção dispostos sobre o piso.

Ocupa uma área próxima à mata natural, está inserida em área de proteção de mananciais e há em suas dependências um poço profundo; a distância até a edificação mais próxima é inferior a 50 (cinqüenta) metros e esta posicionada na encosta.

O Grupo 23 engloba as indústrias que fabricam e manipulam plástico, representa um segmento dos mais ligados à indústria de auto-peças do $A B C$. Como exemplo de indústria que produz matéria-prima para o setor plástico, será descrita a 1000319, que tem sua produção voltada para os compostos "pellets" de PVC e a borracha termoplástica (BT).

Com área total estimada em 26.000 (vinte e seis mil) $\mathrm{m}^{2}$, produz compostos de policloreto de vinila (PVC) na quantia de 1,6 $\times 10^{3}$ (um mil e seiscentos) T/mês e compostos de borracha de butadieno-estireno (SBR) ou BT na razão de 150 (cento e cinqüenta) T/mês, são utilizadas como matéria prima a resina de PVC na ordem de 1.200 (um mil e duzentos) L/mês, estireno-butadieno com um total de 150 (cento e cinqüenta) $T /$ mês, plastificantes (não especificados) 1.600 (um mil e seiscentos) $\mathrm{L} /$ mês, pigmentos 400 (quatrocentos) T/mês e $\mathrm{Ca}_{2} \mathrm{CO}_{3}$, como carga, em um total mensal de 200 (duzentos) $\mathrm{T}$.

Os óleos utilizados no processo são: hidráulico, para compressores de ar e lubrificantes, com um consumo médio de um tambor de 200 (duzentos) L/mês para cada produto. Outro produto derivado do petróleo utilizado é o querosene, utilizado na limpeza de peças, também nessa proporção.

Utilizando-se a tabela de fabricação de artigos plásticos (anexo II) foram estimados os grupos contaminantes dessa atividade, como sendo o de ácido, base e anidrido (ácido fórmico), do ftalato (anidrido ftálico) e o cianeto (cianeto de potássio) que é utilizado como pigmento. 
Quanto à ocupação da área: apontada como critério principal 3 (três) na sistemática de pontuação, ocupa uma área com interesse público, em seu entorno há residências sem hortas, em sua área há mata natural, está contida em área de manancial, nos itens bacia hidrográfica para abastecimento e represa para abastecimento público, possui poço para abastecimento domiciliar/industrial em suas dependências.

Encontra-se posicionada, em relação ao relevo, na encosta e quanto ao contexto hidrogeológico, está no Cristalino com manto arenoso em área de recarga.

Outras indústrias que utilizam materiais termoplásticos para produção de autopeças são 1000321, 329 e 399, cabe ressaltar que nessas há um processo de produção, onde os pellets de termoplásticos (como os compostos de PVC) são injetados sob pressão hidráulica em um molde, denominado "injeção em moldes".

O polietileno de alta e baixa densidade, o poliuretano, e o naylon foram alguns dos termoplásticos relatadas nos MCEs das indústrias e confirmados em campo. Para se completar as misturas podem ser adicionados plastificantes, como o dioctil ou o ftalato (dioctila (DOP)), quando então a massa plástica será injetada sob pressão em um molde. Devemos ressaltar que todo o processo é hidráulico e utiliza para a manutenção dos equipamentos os seguintes componentes: óleo hidráulico, graxa e querosene.

Tanto EPA/Bro Region III (2000) como GLOEDEN (1999) descrevem que a produção e manipulação de termoplásticos podem contaminar o solo e águas (subterrânea e superficial). A contaminação está relacionada à manutenção dos equipamentos e a resíduos de produção (quando da alimentação das injetoras). As substâncias apontadas pelos autores, são: os óleos (hidráulico e lubrificante), surfactantes, fenóis, solventes (halogenados), agentes plastificantes, resinas, derivados de petróleo e os resíduos sólidos.

Outra técnica utilizada para a produção de termoplásticos é a extrusão. Caracterizase pela passagem forçada de uma massa de plástico, aquecida, por um tubo estreito 
e após essa passagem o produto extrusado é resfriado em condições de temperatura ambiente.

O exemplo que melhor traduz esse processo foi observado em 1000329 , pois seus principais produtos são: tubos, mangueiras e esguichos plásticos extrusados.

Localizada junto ao córrego da vila Belmiro, 1000329 produz 32 (trinta e duas) T/mês de mangueiras, 24 (vinte e quatro) T/mês de tubos de polietileno, utilizando o método de extrusão onde as matérias primas utilizadas para se obter essa produção, são: PVC na ordem de 25 (vinte e cinco) T/mês, plastificante dioctil ftalato com 8 (oito) T/mes e uma tonelada de pigmento máster-batch.

$\mathrm{Na}$ inspeção de campo foi observado que houve, na área, vários episódios de enchente (marcas nas paredes externas e internas do galpão) provocadas pelo córrego acima citado, seu piso apresenta rachaduras e manchas de óleo lubrificante. No tanque aéreo cilindrico, com capacidade para trinta mil litros, onde é estocado o plastificante DOP (dioctil-ftalato), havia escorrimento de produto in natura por toda parede externa do tanque formando poças no piso. Foi observado que não há barreira de contenção, junto a esse tanque.

No entorno da propriedade foram observadas utilidades públicas como rede de esgoto, escola, mata natural, aqüíferos importantes e em sua área há um poço para abastecimento domiciliar/industrial.

Quanto ao relevo, localiza-se na várzea estando situada no Quaternário, com uma variação de nível da água estimada inferior a um metro. Foi considerada a possibilidade que essa área exerça influência direta sobre as águas superficiais, devido às substâncias presentes na área e às condições de piso e episódios de enchentes já relatados.

As indústrias 1000257, 1000368, 1000341, e 1000345 utilizam os denominados: plásticos termoestáveis. Esses plásticos possuem a propriedade de que após a cura 
da massa (resfriamento e enrijecimento das peças) tornam-se praticamente insolúveis e infusiveis.

Todas utilizam isocianato (compostos que contém grupos: $R-N=C=O$ ) e poliol ( $\mathrm{R}_{2} \mathrm{OH}$, reagentes polifuncionais). A combinação desses elementos produz o polímero denominado uretana, podendo ser incluso um gás para expansão dessa mistura resultando no que popularmente se conhece como espuma de poliuretano. As substâncias presentes nessas áreas foram: o poliol Specflex NR 571 pol (nome comercial) da Dow Química e o isocianato (diisocianato de 4,4 - difenilmetano, pertencente ao grupo contaminante cianeto) da Bayer do Brasil. As quantias dos produtos que são utilizados nessas indústrias variam segundo os pedidos de autopeças.

Em 1000368 há uma unidade de recuperação de solventes que são utilizados nas cabines de pintura, sendo que o produto mais recuperado é o thinner. Os thinners são solventes compostos basicamente por uma mistura de álcool etílico, acetato de etila, toluol, xilol e butil glicol ${ }^{4}$ e a quantia média mensal utilizada é de 200 (duzentos) L/mes.

O recuperador de solvente, sujo, tem a capacidade de regenerar todo o solvente utilizado; é composto por um reator que armazena a borra resultante do fracionamento, um condensador, um trocador de calor e um cilindro para captação do solvente condensado. Na figura 5.4 é exemplificada uma unidade de recuperação de solventes, sujos, similar ao que foi observada em 1000368.

\footnotetext{
${ }^{4}$ Informação oral, Sr. Waldir - Solventex Ind. Quim. Ltda.
} 


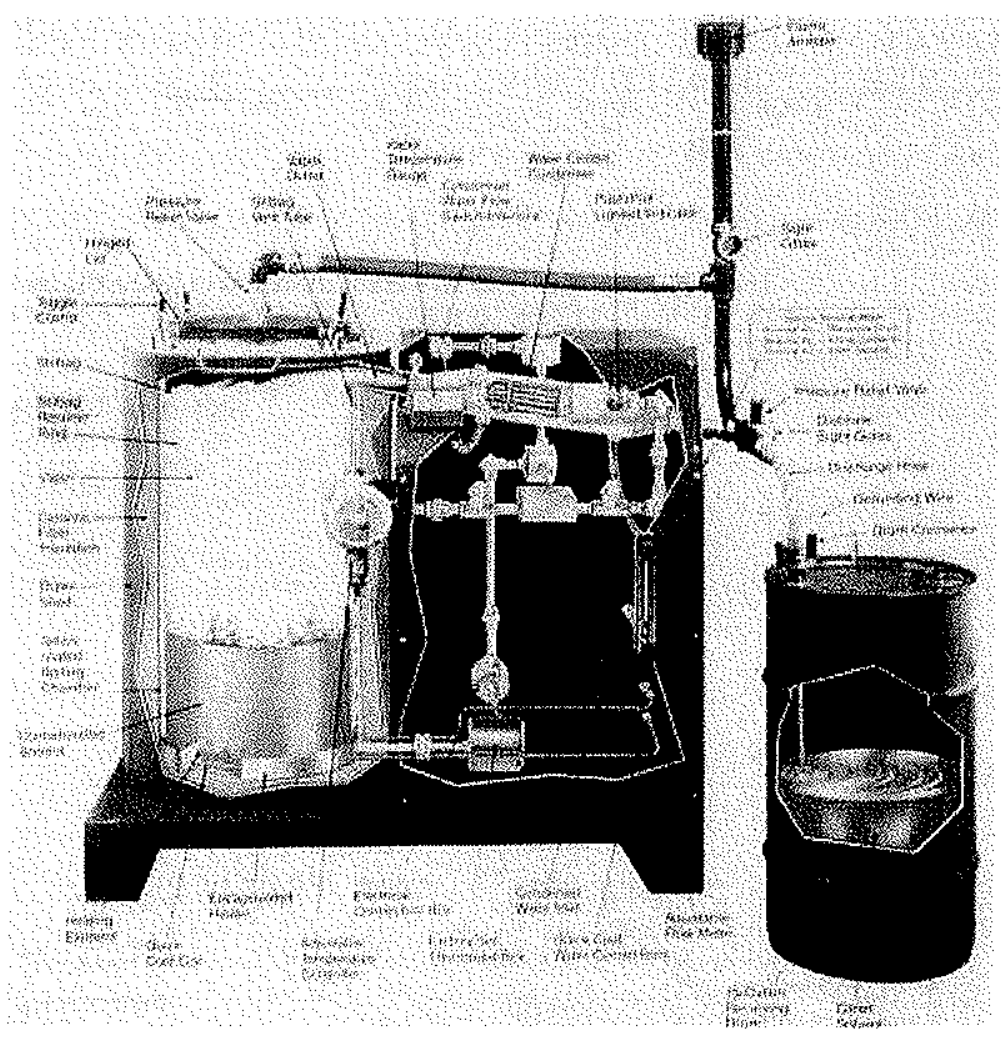

Fonte: Higgins (1995).

Figura 5.4 Unidade recuperadora de solventes, por condensação em indústria de plást́ico.

$\mathrm{Na}$ inspeção de área tanto em 1000341 e 368 , não foi notada nenhuma indicação perceptivel na superfície do solo, tanto na unidade fabril como na área de recuperação de solvente. Ambas estão localizadas em relação ao relevo no topo e no cristalino com manto arenoso em área de recarga.

Outras indústrias inspecionadas que pertencem ao segmento de plásticos foram 1000256 e 1000372, essas utilizam resina poliéster e fibra de vidro para produção de caixas de água, telhas e plásticos reforçados.

Os produtos utilizados em 1000256, são: a resina poliéster na quantidade de 35 (trinta e cinco) T/mês, fibra de vidro com 15 (quinze) T/mes, cetona 100 (cem) L/mês e pigmento gel-colt (resina para carga) 300 (trezentos) $\mathrm{Kg} / \mathrm{mês,} \mathrm{onde} \mathrm{são} \mathrm{produzidas}$ 24,5 (vinte e quatro e meio) T/mês de caixas de água, 6,5 (seis e meio) T/mês de telhas de fibra de vidro. 
Os resíduos gerados são o pó de fibra de vidro e aparas (resina e fibra de vidro), com um total mensal estimado de 5 (cinco) T/mês resultante do processo de acabamento, há um tipo de sistema de tratamento de águas residuárias que consiste em se decantar os sólidos em suspensão, filtrar e recircular a água sem material em suspensão (pó de fibra de vidro).

As condições de impermeabilização na área foram consideradas boas na produção (executada em concreto) e ruins na área de armazenagem de resíduos, pois não há nenhum tipo de revestimento.

Localiza-se junto às margens do ribeirão Pires, em área de várzea e as indicações perceptiveis na superfície do solo foram observadas na área destinada ao acabamento manual de peças que é executado diretamente sobre solo. Foram observados tambores contendo óleo usado, restos de resina, aparas plásticas, cetona dispostos a céu aberto.

Conceitualmente podemos afirmar que as fontes primárias do potencial de contaminação nessa área podem ser ligadas a armazenagem, devido a possíveis derrames e vazamentos dos tambores que acondicionam matérias primas ou resíduos.

O solo foi considerado como fonte secundária de contaminação, segundo os mecanismos de liberação, como exemplo, podemos citar a infiltração de solvente e/ou soluto como a cetona e as resinas diluídas, respectivamente.

Neste raciocínio podem ser apontados como corpos receptores: as águas superficiais e o solo e com potencialidade de contaminação: as águas subterrâneas.

Já 1000372, que produz tanques e peças para saneamento básico, as resinas utilizadas são isoftálica e a orthoftálica, em uma quantidade média de 2 (duas) T/mês, o produto catalizador que é utilizado para cura das resinas é o monômero de estireno na quantidade de 400 (quatrocentos) $\mathrm{Kg} /$ mês e a quantia de cobalto (utilizado como 
acelerador na mistura) é de 100 (cem) $\mathrm{Kg} / \mathrm{mês}$. Os agentes de limpeza de moldes utilizados são a cetona 600 (seiscentos) L/mês e o metil-etil-cetona na quantia de 100 (cem) L/mês.

Quanto ao relevo, localiza-se em encosta e o tipo de impermeabilização do piso é de concreto, está localizada junto à zona viária e ferroviária, em área de proteção de manancial, com aqüiferos importantes.

\section{- Indústrias metalúrgicas desativadas}

O total de indústrias metalúrgicas desativadas, na região de interesse, é de 10 (dez) unidades (quando da execução do estudo). As indústrias são: 1000302, 1000322, 1000337, 1000343, 1000347, 1000348, 1000350, 1000374, 1000403 e 1000443. As atividades citadas estão inclusas nos códigos de atividade IBGE do grupo 11.15, fundição de metais e no 13.84 (acabamento de superfícies metálicas). A seguir serão descritos alguns exemplos.

A atividade principal da 1000302 consistia em fundir peças de ferro cinza, bronze, alumínio, latão e prestação de serviço terceirizado de usinagem de peças metálicas. Ocupando uma área de aproximadamente 4.000 (quatro mil) $\mathrm{m}^{2}$, possui um galpão semi-acabado de alvenaria de 1500 (mil e quinhentos) $\mathrm{m}^{2}$.

As condições de impermeabilização do galpão foram consideradas únicas neste estudo, pois seu piso é da seguinte forma: $50 \%$ (cinqüenta por cento) em concreto e $50 \%$ terra batida, pois o método de fundição adotado era o de se fabricar as peças em moldes feitos em "areia de fundição" diretamente sobre o solo. Neste galpão há um tanque de óleo combustivel aéreo, com sinais de vazamento nas laterais e foram observadas algumas poças de óleo combustivel no solo.

Por ter iniciado suas operações antes de 1974 (não era passiva de licenciamento pelo órgão ambiental), 1000337 não possui processo junto a CETESB, no entanto encontra-se inclusa no SIPOL/CETESB e seu código IBGE é 12.99, a sua avaliação não foi efetuada, pois o imóvel encontrava-se lacrado quando da inspeção. 
Ocupa uma área de oito mil $\mathrm{m}^{2}$ era especializada na produção de máquinas e equipamentos de refrigeração para supermercados e afins.

Como não houve a possibilidade de se efetuar a avaliação, a descrição do tipo e destino das águas residuárias, condições de impermeabilização e tipo de piso, existência de vazamentos ou infiltrações, existência de solo contaminado e a influência que essa pode exercer nas águas superficiais essas informações foram anotadas como desconhecidas na ficha cadastral.

Quanto às condições de tratamento de águas residuárias, impermeabilização (estado e tipo), existência de vazamentos ou infiltrações, influência direta da área em águas superficiais e para se estimar as substâncias presentes na área utilizou-se da tabela 17 - anexo II.

As indústrias 1000347 e 1000348 foram cadastradas de diferentes maneiras, pois as mesmas executavam a mesma atividade que era a produção de utensílios de alumínio obtidos pela fundição de lingotes de alumínio metálico (matéria prima), estampo ou repuxo das placas, discos e fitas de alumínio que são resultantes do processo metalúrgico.

Não há o processo de licenciamento de instalação e funcionamento (LI, LF) de 1000347, mas o acesso a área foi possivel (área externa, até a unidade de manutenção). Já 1000348 têm seus processos de instalação e funcionamento, mas não houve possibilidade de se efetuar a avaliação, pois o imóvel encontrava-se fechado e a imobiliária não dispunha das chaves.

A descrição dos materiais utilizados em 1000348 , confirmados pelo processo CETESB e estimados para 1000347, foram lingotes de alumínio, óleo (hidráulico, lubrificante, de estampagem, solúvel e protetivo), percloroetileno e papelão. 
Como citado, em 1000337 o mesmo ocorreu em 1000347 quanto a descrição do tipo de piso, destino das águas residuárias, todos esse itens foram considerados desconhecidos.

Basicamente, o que difere em ambas, é o posicionamento da área quanto ao relevo e a hidrogeologia. 1000347 está situada em encosta e no cristalino com manto arenoso em área de recarga enquanto que 1000348 está localizada em área de várzea e no contexto geológico Quaternário.

A atividade industrial $13.84 .99-5$ é descrita pelo IBGE como sendo aquela que fabrica sistemas de alto-falantes, esta era a principal atividade de 1000443, mas a área inspecionada era somente utilizada como unidade de galvanoplastia.

A seguir, como foi feito com o produto óleo (vide item 5.4.2), o autor optou por descrever a atividade de tratamento de superfície, juntamente com a descrição de 1000443 , pois todos os processos que serão descritos foram contemplados nessa unidade e os mesmos são relatados em seu processo CETESB.

A atividade de uma galvanoplastia pode ser definida como aquelas operações que envolvem o preparo e o acabamento de superfícies metálicas para um dado uso. As operações podem incluir desengraxe, decapagem, eletrodeposição de metais, passivação (controle de oxidação), fosfatização, eletrodeposição química e anodização (HIGGINS, 1995).

As etapas de um tratamento galvânico, segundo QUÍMICA E DERIVADOS (1998) e CETESB (1990), são: o pré-tratamento das peças, o acabamento principal e o póstratamento.

As etapas de pré-tratamento têm por objetivo a remoção da superfície metálica dos óleos, graxas e óxidos que estão, via de regra, agregados a essas e são efetuados pela utilização de desengraxante químico, eletrolítico ou pela utilização de agente decapante. 
O acabamento principal é efetuado por sais e aditivos para eletrodeposição de metais, como zinco e suas ligas, níquel, cromo, estanho e outros, bem como a fosfatização para que as peças possam ser pintadas ou que essas possam dispor da capacidade de dureza ou de se deformar a frio, pois após o acabamento forma em sua supefície uma película que confere uma dada resistência para que essas resistam também a corrosão e possam formar substratos onde outras substâncias possam se ancorar.

Os pós-tratamentos visam a melhoria visual por meio da utilização de agentes passivadores (material antioxidante, usado em banhos com prata).

Os processos de produção desenvolvidos em 1000443, eram: linha automática de strip-plating (remoção de capeamento), banhos de prata, estanho, níquel, zinco, cromatização e abrilhantamento, passivante, douração automática e normalização. Os processos eram independentes e podiam ser interligados (vide figura 5.5).

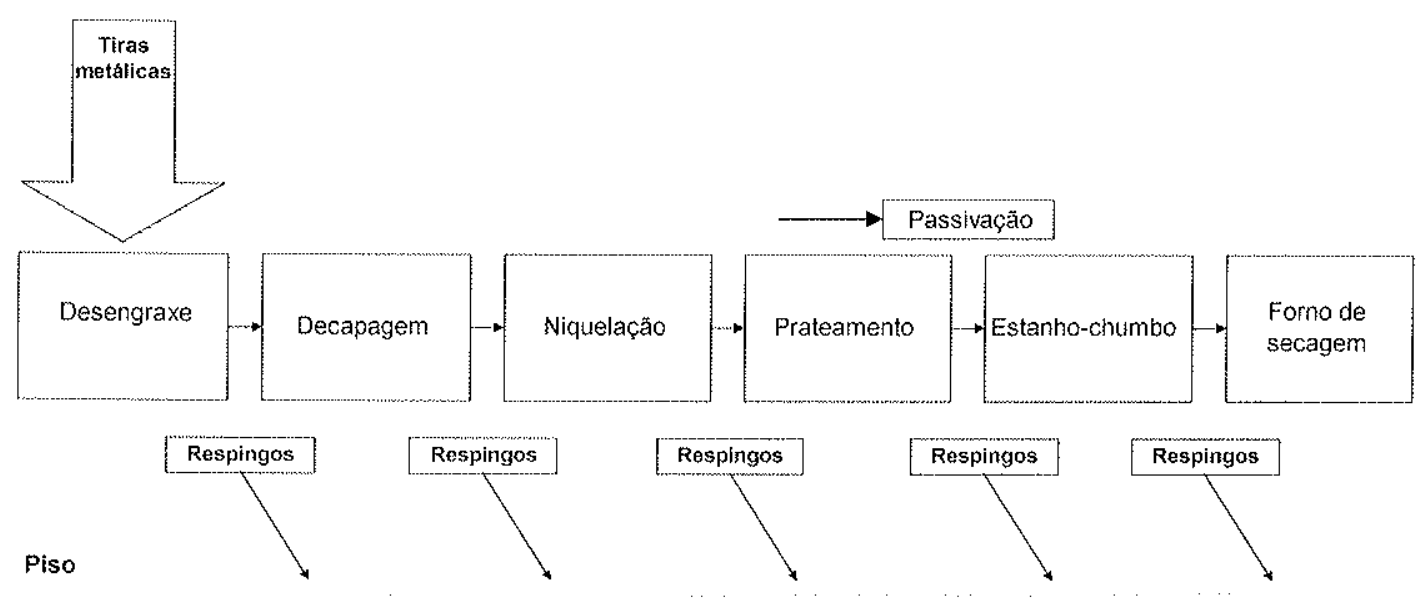

Fonte: Processo CETESB 01.1044-1, (modificado).

Figura 5.5 Processo automático de eletrodeposição que era executado em 1000443, demonstrando as prováveis fontes de contaminação (a produção e a armazenagem de substâncias) aos bens a proteger.

Para efeito de inspeção de campo, os dados apontados na ficha cadastral, foram: galpão com área coberta de 900 (novecentos) $\mathrm{m}^{2}$, a atividade de galvanoplastia 
iniciou-se em meados de 1971 e foi encerrada em 1990. As matérias-primas, suas quantidades e utilização no processo, foram:

\begin{tabular}{|l|l|}
\hline MATÉRIA PRIMA - T/mês & UTLIZACÃO \\
\hline Ácido acético $-1,75$ & Agente decapante \\
\hline Ácido clorídrico $-13,2$ & Agente decapante \\
\hline Ácido nítrico $-0,5$ & Acabamento de peça zincada \\
\hline Anodos de $\mathrm{Cu}, \mathrm{Ag}, \mathrm{Zn}, \mathrm{Co}, \mathrm{Es}, \mathrm{Ni}-0,6$ & Agentes eletroativos \\
\hline Bicromato de potássio $-0,004$ & Agente passivador \\
\hline Cianeto de potássio $-0,07$ & Revestimento metálico, banho eletrolítico \\
\hline Cianeto ouro-potássio $-0,005$ & Revestimento metálico, banho eletrolítico \\
\hline Cianureto de cobre $-0,04$ & Revestimento metálico, banho eletrolítico \\
\hline Fluorborato de estanho $-0,3$ & Revestimento metálico, banho eletrolítico \\
\hline Graxa - não defindo. & Manutenção de equipamentos \\
\hline Hidróxido de sódio $-0,9$ & Desengraxante alcalino à quente \\
\hline Hipofosfito de sódio $-2,5$ & Desengraxante \\
\hline Oleo hidráulico - não definido & Manutenção de equipamentos \\
\hline Peróxido de hidrogênio $-0,05$ & Agente decapante \\
\hline Solventes clorados (TCE, PCE) - 1,0 & Desengraxantes \\
\hline Sulfato de níquel $-2,03$ & Revestimento metálico \\
\hline
\end{tabular}

O tipo de piso da unidade avaliada é de concreto e apresenta um grande número de rachaduras, com indicações de manchas de óleo e outros produtos, poças de água, bombonas com produtos (sem etiquetas) e restos de embalagem (não foi permitido 0 registro fotográfico).

Localiza-se em área de várzea, no contexto geológico Quaternário e não houve relato de ocorrência de acidentes ou eventos importantes no processo CETESB, usado como fonte de dados.

\section{- Indústrias metalúrgicas ativas.}

As indústrias do setor metalúrgico que estão ativas na região de interesse serão descritas em relação ao tipo de produto, seu processo de fabricação e serviços que oferecem.

Devido ao número elevado de empresas a se descrever, optou-se por agrupar as informações segundo as ferramentas que o cadastro de áreas contaminadas digital proporciona, ou seja, é possível, em seu ícone de relatórios quantificar e qualificar as indústrias, ou seja: as indústrias que utilizam óleo de estampagem em um mesmo ambiente hidrogeológico. 
O universo das indústrias metalúrgicas ativas abrangeu desde unidades de manutenção de tratores e máquinas para mineração até a fabricação de armas e explosivos. Essa amplitude de atividades, onde a similaridade em grande parte é somente o código de atividade IBGE, mostrou a necessidade de se agrupar e qualificar os materiais que fazem parte de seus processos que na ficha cadastral são apontados no item 5.1 (Substâncias presentes na área).

A seguir há a descrição dos materiais utilizados, produzidos e armazenados de cada área que são mencionados com maior freqüência, tanto nos processos CETESB como nas inspeções de campo. Os produtos estão separados por grupos, como: óleos, graxas, solventes, decapantes e outros.

1. Grupo Óleo: Os tipos de óleos que foram relatados nos processos CETESB ou verficados nas inspeções de campo são:

la - óleo de corte, as seguintes indústrias o utilizam: 1000304, 1000313, 1000400, 1000309, 1000312, 1000330, 1000383, 1000310, 1000349, 1000324, $1000305,1000325,1000373,1000401,1000398,1000402$ e 1000370.

Ib - óleo para eletroerosão, somente é utilizado em 1000400 ,

Ic - óleo para estampagem, utilizado em 1000312, 1000313, 1000375 e 1000401,

Id - óleo protetivo, os óleos protetivos utilizados são, de origem vegetal em 1000313 e em 1000315, já os óleos protetivos de origem mineral são utilizados em 1000312 e 1000375 ,

le - óleo hidráulico, é utilizado em 1000304, 1000313, 1000315, 1000330 , $1000344,1000349,1000370,1000375,1000383,1000384,1000400$ e 1000402 ,

If - óleo para refrigeração, 1000383 e 1000369 , 
lg - óleo solúvel, utilizado em 1000304, 1000315, 1000370 e 1000392,

Como exemplo de unidade industrial que utiliza diferentes tipos de óleos em seu processo produtivo será descrita: 1000375. Empresa fundada em 1977, com área total estimada em 55.000,00 (cinqüenta e cinco mil) $\mathrm{m}^{2}$ têm como objetivo principal à produção de utensílios domésticos, estampados, em alumínio.

A partir da fundição dos lingotes de aluminio, em média 90 (noventa) T/mês, são produzidos 40 (quarenta) T/mês de chapas, 20 (vinte) T/mês de discos, 10 (dez) T/mês de tiras e 20 (vinte) T/mês de utensílios domésticos

São utilizados quatro tipos de óleos, para se obter esse volume de produção, a saber: o hidráulico, o lubrificante, o de estampagem e o protetivo (a base de isoparafina) em uma quantia média mensal de duzentos litros cada.

Deve-se ressaltar que antes do emprego do óleo protetivo as peças sofrem um processo de desengraxe químico feito pelo solvente percloroetileno (PCE) que é utilizado em um volume de 200 (duzentos) L/mês, após este processo de limpeza as peças são secas em estufa e recebem o oleamento de proteção.

II Grupo Graxa: as indústrias metalúrgicas ativas que mencionaram em seus processos que utilizam graxa para fins de lubrificação de seus equipamentos foram: 1000313 e 1000330, mas em campo constatamos que todas a utilizam.

III Grupo Solventes: os tipos de solventes utilizados nos processos metalúrgicos de desengraxe, diagnosticados em campo e algumas vezes relatados nos processos, foram:

IIla-1,1,1-tricloroetano (TCA), utilizado em 1000277,

IIlb - Percloroetileno, utilizado em 1000375 como produto secante de metais, 
IIIc - Querosene, produto da refinação do petróleo, o querosene é a substância mais utilizada como desengraxante de peças metálicas nas indústrias avaliadas, as que o utilizam, são: 1000277, 1000312, 1000324, 1000330, 1000338 e 1000376.

Illd - Thinner, é utilizado em 1000200, 1000277, 1000309, 1000312, 1000360 e 1000382.

IV Grupo Decapantes: Os tipos produtos utilizados nos processos de decapagem, diagnosticados em campo e algumas vezes relatados nos processos de licenciamento, foram:

IVa - Ácido sulfúrico, utilizado em 1000276 e 1000320,

IVb - Ácido clorídrico, utilizado em 1000276, 1000277, 1000315 e

IVc - Ácido fluoridrico, utilizado em 1000315.

V Grupo Outros produtos utilizados em tratamentos de superficies metálicas: Os tipos de produtos utilizados em tratamentos de superficies metálicas foram:

Va - Ácido nítrico, agente passivador utilizado em 1000277 e 1000276 ,

$\mathrm{Vb}$ - Ácido crômico, matéria prima utilizada na cromeação de peças é utilizado em 1000276 e 1000277 e

Vc - Soda cáustica, utilizada em 1000276, 1000277 e 1000315.

Os produtos acima foram assinalados nas fichas cadastrais, no item 5.1 , como substâncias que foram confirmadas nas áreas avaliadas, no entanto utilizou-se para se estimar possíveis substâncias presentes em 1000304 a tabela 27 do anexo II, pois essa mesma área foi anteriormente ocupada por uma unidade galvânica (linha desativada). 
Outra empresa em que foram observadas bases de tanques para banhos galvânicos foi 1000276. Quando da inspeção não executava tratamento galvânico em sua unidade de Ribeirão Pires, mas até meados de 1992 (informação oral) o processo de tratamento operava. O fluxograma de fabricação que está anexado ao processo CETESB, desenhado em 1977, mostra toda linha de produção, suas atividades e contempla também os tipos de efluentes gerados (sólidos, líquidos e gasosos). Vale ressaltar que este diagrama contém também o tratamento a que determinados metais eram submetidos para a fabricação de armas de fogo, hoje esta linha foi transferida para outra unidade e o processo que resta na unidade RP é somente a forja de canos.

Para se obter a produção de munição de caça e de defesa em um volume $11 \times 10^{6}$ (onze milhões) de un/mês, cartuchos de diversos calibres $3 \times 10^{6}$ (três milhões) un/mês e espoletas em um total de $41 \times 10^{6}$ (quarenta e um milhões) de un/mês são utilizados os seguintes materiais: latão e tomback - 105 (cento e cinco) T/mês, chumbo - 67 (sessenta e sete) T/mês, antimônio - 270 (duzentos e setenta) T/mês, ferro laminado -8 (oito) T/mês, nitrocelulose -16 (dezeseis) T/mês, papel e papelão -5 (cinco) T/mês, ácido nítrico - 1.000 (um mil) L/mês, ácido sulfúrico 6.000 (seis mil) $\mathrm{L} /$ mês, álcool - 14.000 (quatorze mil) L/mês, acetona - 6.500 (seis mil e quinhentos) L/mês, óleo combustível - 180.000 (cento e oitenta mil) L/mês

Deve-se ressaltar que dada a particularidade do tipo de produto elaborado e a dimensão territorial 2 (dois) milhões de $\mathrm{m}^{2}$, bem como o número de áreas edificadas (algumas até subterrâneas), optou-se por se definir critérios para a descrição dessa área. No caso do contexto geológico ficou definido como sendo o Quaternário.

As condições de piso em todas as unidades visitadas foram consideradas boas e excelentes na fábrica de pólvora. Há uma estação de tratamento de efluentes própria e os principais efluentes, são: águas residuárias da seção de mistura iniciadora, águas ácidas (decapagem), águas alcalinas (processo de alcalinização, possivelmente utilizando-se soda cáustica), águas de cobreação e latonagem (tratamentos eletrolíticos), esses dados foram coletados no processo CETESB e mantidos pelo autor, mesmo com a unidade galvânica desativada. 
Não foi notado nos pisos das unidades colorações ou indícios de derramamento e somente na área dos tanques (aéreos e com barreiras de contenção) de combustiveis foram notadas algumas manchas.

Como há uma unidade de fundição de chumbo e antimônio os efluentes gasosos com possiveis arrastes de metais não devem ser desprezados.

Utilizando-se a tabela 8 do anexo II, foram estimados os seguintes grupos de contaminantes: solventes orgânicos halogenados, compostos orgânicos nitrogenados, hidrocarbonetos policíclicos aromáticos, fenóis, cianeto e aldeídos.

$\mathrm{Na}$ indústria a água industrial utilizada provém de dois poços profundos e em seu entorno há uma unidade militar, áreas industrial, comercial e residencial, bem como escola e esta localiza-se em área de proteção de mananciais, com aqüíferos importantes que cortam sua área.

\subsubsection{Inspeção de área: Outras fontes/cemitério}

Ocupando uma área estimada em 2 (dois) alqueires o cemitério São José (O000388), código IBGE 99.99.001, está ativo desde 1908, situa-se em área de encosta com predominância de solo arenoso. No local foram notados sinais de erosão laminar, rachadura no pavimento de concreto e algumas sepulturas comprometidas por infiltrações de água.

A impermeabilização do piso foi considerada: metade pavimentada com concreto $\mathrm{e}$ outra metade sem pavimentação.

Na ficha cadastral de áreas contaminadas o necrochorume foi apontado no item 4.4 Material/Resíduo, o destino das substância/material envolvidos foi apontado como: infiltração no solo. Já os item 5.1 (substâncias presentes na área), 5.14 e 5.15 (água superficial contaminada por influência da área), foram considerados como sendo desconhecidos. 
5.4.3.5 Inspeção de área: Disposição de resíduos

Denominado Antigo Lixão de Ribeirão Pires, localizado na estrada da Sondália, km 8,5 (oito e meio), foi avaliado pela CETESB quando da formação do cadastro de áreas contaminadas, mas neste estudo não será objeto de classificação, pois se localiza fora da bacia hidrográfica Billings.

\subsection{Classificação 1}

A classificação das áreas foi executada quando foram concluídas as inspeções de campo. Do total de 109 (cento e nove) áreas potencialmente contaminadas, foram classificadas 107, distribuídas da seguinte forma: 58 (cinqüenta e oito) foram consideradas suspeitas, 49 (quarenta e nove) permaneceram como potenciais e 2 (duas) foram excluídas do cadastro de áreas contaminadas.

Na figura 5.6, é demonstrado o resultado da classificação 1 , dividida entre áreas potencialmente contaminadas ou potenciais e suspeitas de contaminação. Cada atividade foi dividida em quadros denominados: Áreas Potenciais e Suspeitas de contaminação. Vale ressaltar que no quadro referente às indústrias suspeitas de contaminação as áreas excluídas do cadastro são demonstradas. 


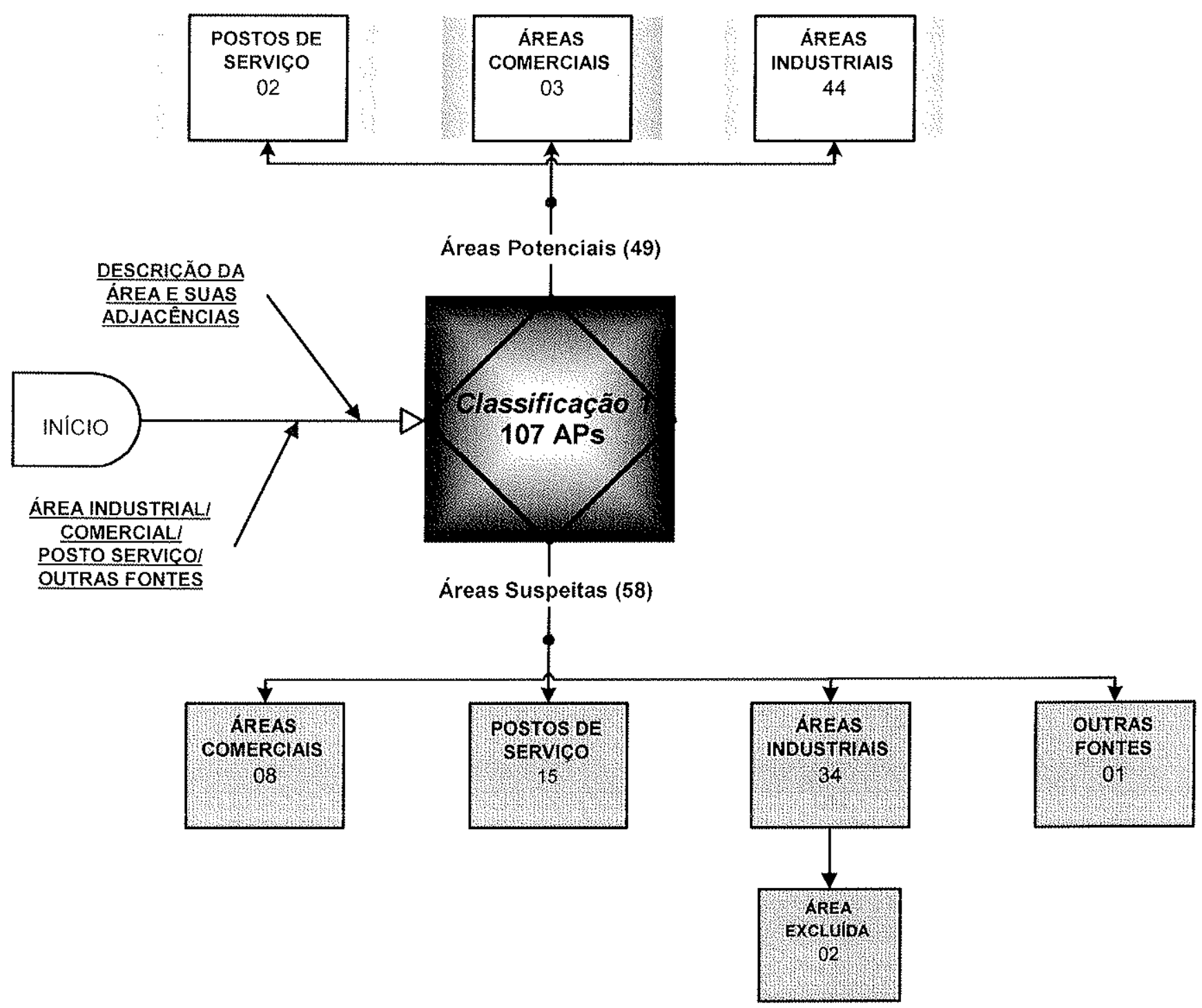

Figura 5.6 Classificação das áreas potencialmente contaminadas, suspeitas e excluídas, atividades e quantidade. 


\section{Priorização 2: Os custos do processo de identificação.}

Como ferramenta na tomada de decisão para o gestor ou para que o municipio de Ribeirão Pires tenha a dimensão da quantificação de custos, serão descritas a seguir, as bases físicas que neste estudo serão o ponto de apoio para se proceder a priorização 2 .

Para se estimar os recursos utilizados nesse estudo, foram computados os dados: de tempo corrido (em meses) para a sua realização, a quilometragem percorrida, a mão de obra utilizada e as despesas efetuadas. Todos os valores foram estimados pela Equipe de desenvolvimento de negócios /CETESB, para o mês de março de 2001.

\subsection{Bases físicas - Os recursos financeiros utilizados na execução do processo de identificação de áreas contaminadas.}

As bases físicas, ou o como COMPASS (1997) identifica como custos diretos ou convencionais, identificadas na execução do processo de identificação de áreas contaminadas, foram:

- Tempo de execução do processo de identificação,

- Mão de obra direta,

- Despesas não tabeladas,

- Despesas tabeladas e

- Preço das análises de laboratório.

6.1.1 Tempo de execução do processo de identificação

O tempo de execução de todo processo de identificação de áreas contaminadas no município de Ribeirão Pires, foi quantificado pelo tempo de execução das inspeções de campo em um total de 7 (sete) meses. Este período não compreende a compilação de dados em escritório. 


\subsubsection{A mão de obra direta}

A mão de obra direta utilizada para se proceder a identificação das áreas, foi dividida por cargos, quantidade de horas/homem e seu preço, resultando em:

\begin{tabular}{|c|c|c|c|}
\hline Cargo & $\mathrm{Q}^{\text {tidade }}$ Horas & Preço (R\$) & Total (R\$) \\
\hline Engenheiro IV & 272 & 110,15 & $29.960,00$ \\
\hline Técnico III & 288 & 61,28 & $17.825,13$ \\
\hline
\end{tabular}

\subsubsection{A despesa tabelada}

A despesa tabelada calculada no processo de identificação, foi:

\begin{tabular}{|c|c|c|c|}
\hline Descrição & $\mathrm{Q}^{\text {tddade }}$ & Valor do despesa (R\$) & Total \\
\hline Quilometragem & 12.818 & $0,93 / \mathrm{km}$ & $\mathrm{R} \$ 11.920,74$ \\
\hline
\end{tabular}

\subsubsection{A despesa não tabelada}

A despesa não tabelada valorada no processo de identificação, foi:

\begin{tabular}{|c|c|c|c|}
\hline Descrição & $\mathrm{Q}^{\text {tidade }}$ & Valor da despesa (R\$) & Total \\
\hline Refeição (RGSP) & 70 & 12,00 & $\mathrm{R} \$ 966,00$ \\
\hline
\end{tabular}

Portanto, para se calcular o custo direto da execução da avaliação preliminar - etapa de "inspeções de campo", no município de Ribeirão Pires, foi definido como sendo o produto resultante da somatória dos itens: mão de obra direta, despesa tabelada e despesa não tabelada.

O valor dos recursos utilizados, ou custo direto CETESB/GTZ, foi de $\mathrm{R} \$ 60.671,87$ (Sessenta Mil, Seiscentos e Setenta e Um Reais e Oitenta e Sete Centavos). 


\subsection{Tomada de decisão para se efetuar a Priorização 2.}

Tomando-se como base o valor do custo direto, foi desenvolvido um sistema decisório onde o critério de decisão recaiu sobre os preços analíticos praticados pela CETESB para alguns parâmetros químicos que neste estudo são utilizados como indicadores de contaminação, foram desenvolvidas duas linhas de decisão. A escolha do laboratório CETESB deve-se principalmente à certificação que esse recebeu do Instituto Nacional de Metrologia, Normalização e Comércio Exterior - INMETRO, em novembro p.p..

A primeira linha de decisão foi tomada no sentido de se calcular o número de amostras necessárias em todas as áreas suspeitas, quais os parâmetros químicos devem ser analisados, os meios a serem amostrados, qual estratégia amostral a ser utilizada, os preços parciais e totais das análises laboratoriaias.

A segunda linha de decisão foi tomada estabelecendo-se um corte ou redução do número de ASs, utilizando-se o cadastro de áreas contaminadas.

\subsubsection{A primeira linha de decisão}

Para se estimar o valor em todas áreas suspeitas de contaminação do estudo, foi idealizado um quadro, baseado nas tabelas de atividades do anexo $\mathrm{II}$, onde foram determinados os parâmetros a serem analisados, segundo a atividade desenvolvida na área, os grupos contaminantes confirmados/estimados (item 5.1 de cada ficha cadastral) e confrontados com a lista das análises que são efetuadas pelo laboratório CETESB.

O resultado dessa estimativa pode ser observada em sua totalidade no anexo III denominado: "Preço das análises laboratoriais para investigação confirmatória, CETESB - Março/2001".

Como exemplo podemos utilizar a atividade de fundição e/ou forjaria. Representada por três áreas suspeitas (1000302, 1000385 e 1000400), para cada uma dessas áreas são sugeridos: 
- Parâmetros a serem analisados (para solo e água subterrânea): série de dez metais, BTX, fenóis, solventes halogenados, cromo hexavalente e sulfato em água,

- A estratégia amostral sugerida é a de número 4 (vide item 4.1.7) modificada para se obter uma amostra de solo e água subterrânea por ponto ao invés de se efetuar as quatro amostras que a estratégia determina,

- Preço (Mar/2001) por ponto (uma amostra de solo e uma amostra de água subterrânea): R\$1.551,21 (Um Mil, Quinhentos e Cinqüenta e Um Reais e Vinte e Um Centavos,

- equipamento sugerido, para se proceder a amostragem de solo e água subterrânea: Geoprobe - custo por metro linear de sondagem $=R \$ 50,00$ (Cinqüenta Reais), profundidade de sondagem (estimada) $=10,00 \mathrm{~m}$, preço estimado por ponto $=\mathrm{R} \$ 500,00$ (Quinhentos Reais), preço total por área $=\mathrm{R} \$$ $2.000,00$ (Dois Mil Reais).

- Preço total de análises laboratoriais e sondagens para as três áreas:

- Preço por área: oito amostras (4 solo e 4 água) $12.409,68$ + valor da sondagem $(R \$ 2.000,00)=R \$ 14.409,68$,

- Preço total $=$ Número de áreas $\times$ Preço por área $(3 \times 14.409,68)=R \$ 43.229,04$ (Quarenta e três Mil, Duzentos e Vinte e Nove Reais e Quatro Centavos).

Tomando-se como base o exemplo acima, para se efetuar em todas as ASs do município de Ribeirão Pires a investigação confirmatória, o valor total de análises laboratoriais da primeira linha de decisão, será de: $R \$ 736.392,72$ (Setecentos e Trinta e Seis Mil, Trezentos e Noventa e Dois Reais e Setenta e dois Centavos).

\subsubsection{A segunda linha de decisão}

A segunda linha de decisão será orientada pela utilização do sistema de pontuação automática que o cadastro de áreas contaminadas proporciona. 
Neste estudo o sistema de pontuação automático do cadastro de áreas contaminadas foi utilizado para se definir a segunda linha decisão, baseado nas informações das fichas cadastrais, sobre:

- As informações das áreas (tipo de atividade e dimensões),

- As substâncias do processo (confirmadas ou estimadas),

- A importância do uso do solo,

- Posicionamento da área em relação aos bens a proteger segundo seu raio de influência (tanto interno como externo) e

- A importância das vias de transporte dos contaminantes.

$\mathrm{Na}$ figura 6.1 pode-se observar como são as relações entre as características das áreas avaliadas, os critérios de priorização e as notas ou pontuações resultantes (intervalos de pontuação). 


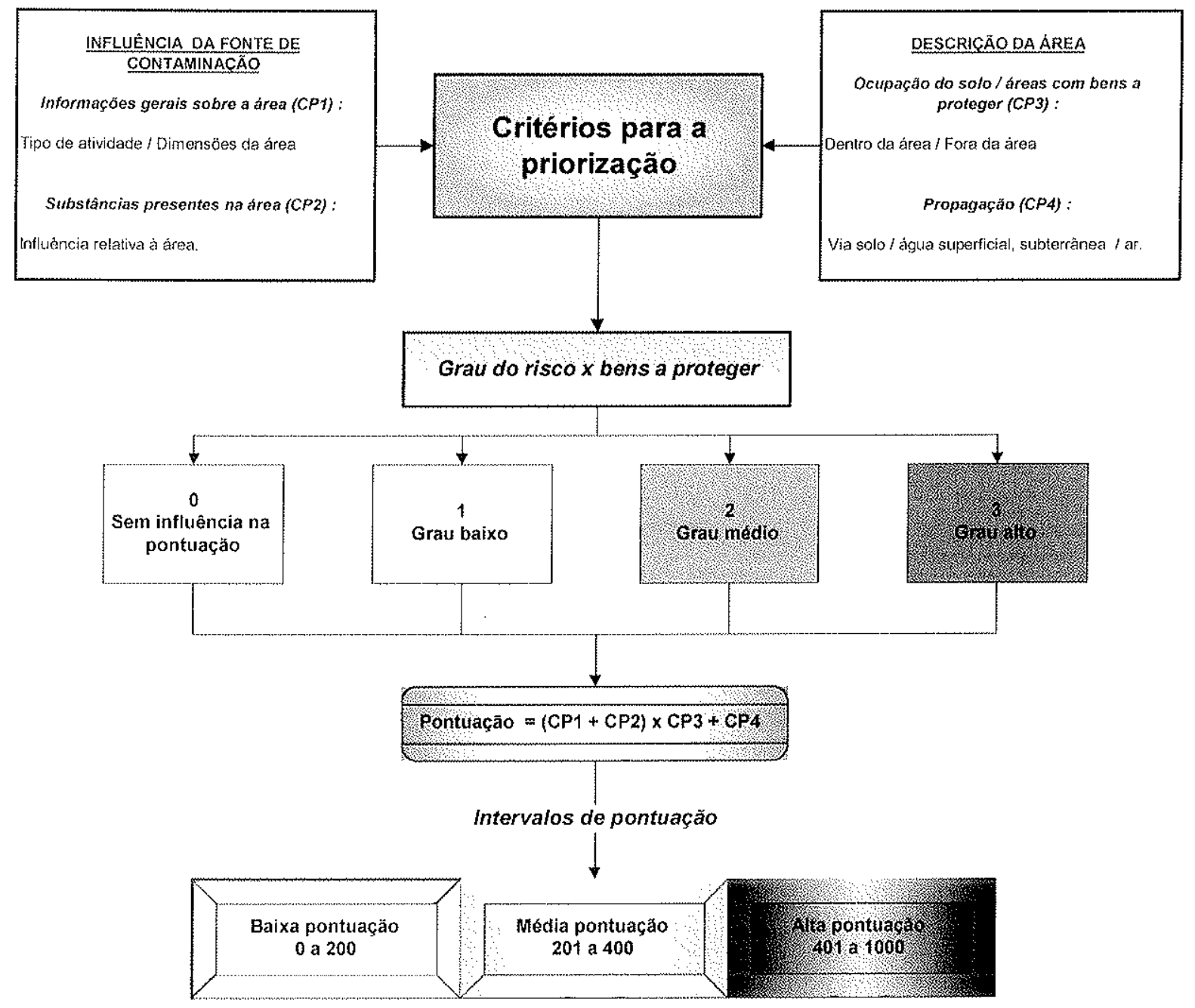

Figura 6.1 Critérios de priorização e os intervalos de pontuação.

Para o cálculo do binômio risco provável aos bens a proteger e tipo de fonte de contaminação, foi desenvolvido no cadastro de áreas contaminadas o que denominou: "Variação dos critérios de pesquisa para os bens a proteger: Abastecimento de água potável (BP2) e os Recursos hídricos - subterrâneos e superficiais (BP4)".

A variação dos critérios de pesquisa que foram solicitados ao sistema (cadastro de áreas contaminadas) em relação a $\mathrm{BP} 2 / \mathrm{BP} 4$, foram o número e o código das áreas que se localizam nos intervalos de pontuações de 0 a 100 (zero a cem), as que estão no de 101 a 200 (cento e um a duzentos), no intervalo de 201 a 300 (duzentos e um a trezentos), idem para 301 a 400 (trezentos e um a que mostra quatrocentos), de 401 a 500 (quatrocentos e um a quinhentos), de 501 a 600 (quinhentos e um a 
seiscentos), de 601 a 700 (seiscentos e um a setecentos), de 701 a 800 (setecentos e um a oitocentos), de 801 a 900 (oitocentos e um a novecentos) e finalmente de 901 a 1000 (novecentos a um mil) pontos. O resultado do ensaio pode ser observado no quadro 6.1.

Quadro 6.1 Resultado do ensaio dos intervalos de pontuação.

\begin{tabular}{|c|c|c|}
\hline Intervalos de pontuação & Número de áreas & $\begin{array}{c}\text { Pontuações para } \\
\text { BP2/BP4 }\end{array}$ \\
\hline $000-100$ & 58 & Baixa \\
\hline $101-200$ & 58 & Baixa \\
\hline $201-300$ & 54 & Média \\
\hline $301-400$ & 46 & Média \\
\hline $401-500$ & 24 & Alta \\
\hline $501-600$ & 15 & Alta \\
\hline $601-700$ & 07 & Alta \\
\hline $701-800$ & 00 & Alta \\
\hline $801-900$ & 00 & Alta \\
\hline $901-1000$ & 00 & Alta \\
\hline
\end{tabular}

6.2.3 A justificativa da opção pelas áreas com alta pontuação.

O conceito de pontuações baixa, média e alta, foi desenvolvido segundo CETESB (1999), fundamentado nos critérios de risco que foram desenvolvidos pelo estado alemão de Nordrhein-Westfalen, para dotação orçamentária na execução, hierarquização e remediação de áreas suspeitas e/ou contaminadas

O sistema de pontuação possibilita diferentes combinações na aplicação e ensaios de notas. A nomenclatura alta, média e baixa é relacionada sempre ao bem a proteger que estamos objetivando. Como o município de Ribeirão Pires tem sua área territorial toda incluída em área de manancial e o ribeirão que dá nome à cidade é o um dos principais afluentes do rio Grande, que por sua vez contribui na formação do reservatório Billings, optou-se por pontuar ou atribuir valores às áreas suspeitas de 
contaminação em relação aos bens a proteger BP2 (abastecimento de água potável) e os recursos hídricos, tanto superficiais com subterrâneos - BP4.

Com o objetivo de se efetuar a redução do número de áreas o gestor do processo de identificação optou por estudar as áreas que estão localizadas no intervalo de alta pontuação para os bens a proteger BP2/BP4 (vide quadro 6.1), devido aos seguintes aspectos:

- Todos os segmentos industriais e comerciais avaliados estão representados,

- A redução do número de áreas a serem investigadas "a posteriori" foi alcançado,

- A área suspeita de contaminação com a nota mais alta de todo o cadastro de áreas contaminada CETESB/GTZ, está contemplada (1000302)

- E as áreas que estão no intervalo 401 a 500, estão exatamente na metade da escala de pontuação que vai de 0 a 1.000 (zero a um mil) pontos.

De um total de 58 áreas que foram classificadas como suspeitas de contaminação no item 5.5, utilizando-se o sistema de pontuação do cadastro de áreas contaminadas para o intervalo desejado, obtivemos uma redução de 12 (doze) áreas que representam $21 \%$ (vinte e um por cento) do total de áreas. As 46 (quarenta e seis) áreas suspeitas localizadas no intervalo de alta pontuação e suas respectivas notas, são:

- Áreas industriais: $1000283(468,20), 1000305(499,00), 1000309(418,90), 1000312$ $(493,10), 1000314(450,40), 1000330(493,10), 1000340(477,20), 1000380(468,20)$, $1000383(493,10), 1000392(468,20), 1000305(499,00), 1000277(517,80), 1000302$ $(700,20), 1000303(584,30), 1000304(517,80), 1000313(645,10), 1000315(594,80)$, $1000316(658,70), 1000337(621,30), 1000347(566,20), 1000348(566,20), 1000350$ $(537,60), 1000374(503,40), 1000375(503,40), 1000380(468,20), 1000382(566,20)$, $1000384(566,20), 1000385(543,90), 1000400(647,70)$.

- Áreas comerciais: C000232 (520,80), C000355 (614,00), C000379 (531,90). 
- Postos de serviço automotivo: P000130 (443,80), P000191 (450,40), P000192 $(418,90)$, P000193 (450,40), P000200 (418,90), P000201 (450,40), P000202 $(418,90), P 000231(418,90), P 000233(450,40), P 000235(418,90), P 000236$ $(477,20), \mathrm{P} 000237$ (418,90), P000238 (477,90), P000239 (418,90).

No entanto se o bem a proteger do estudo fosse o BP1 (vida e saúde da população (impacto direto)) e o tipo de contaminação industrial/comercial os intervalos de pontuação, seriam:

$\Rightarrow$ Baixo: de 0 a 40 (zero a quarenta),

$\Rightarrow$ Médio: de 41 a 80 (quarenta e um a oitenta) e

$\Rightarrow$ Alto: acima de 80 (oitenta).

Se as mesmas áreas que foram priorizadas para BP2/BP4 forem mantidas, temos as seguintes notas:

- Áreas industriais: 1000283 (114,60), $1000305(135,40), 1000309(126,70), 1000312$ $(149,20), 1000314(135,90), 1000330(142,50), 1000340(128,30), 1000380(135,30)$, $1000383(149,20), 1000392(135,20), 1000305(135,40), 1000277(121,20), 1000302$ $(139,00), 1000303(90,60), 1000304(128,90), 1000313(135,90), 1000315(121,20)$, $1000316(120,90), 1000337(159,30), 1000347(117,00), 1000348(115,10), 1000350$ $(163,90), 1000374(144,60), 1000375(119,90), 1000380(468,20), 1000382(566,20)$, $1000384(566,20), 1000385(142,70), 1000400(144,60)$.

- Áreas comerciais: $\operatorname{Co00232}(215,10), \operatorname{Co00355}(149,40), \operatorname{Co00379}(149,40)$.

- Postos de serviço automotivo: P000130 (73,40), P000191 (112,50), P000192 $(118,10)$, P000193 (118,10), P000200 (121,10), P000201 (109,50), P000202 $(103,90)$, P000231 (103,90), P000233 (112,50), P000235 (121,10), P000236 $(128,30)$, P000237 (115,40), P000238 (115,40), P000239 $(115,40)$. 


\subsubsection{Valoração da segunda linha de decisão}

Para se calcular os valores necessários para se efetuar a quantificação de recursos, foi utilizada a mesma metodologia utilizada na primeira linha decisória, ou seja o valor por área (subtotal) e o valor total. Os valores, os parâmetros, estratégia amostral a ser utilizada e os valores por área, estão apresentados no anexo III.

O valor obtido na segunda linha de decisão, quando foi feito o corte no número de áreas foi de $\mathrm{R} \$ 547.956,40$ (Quinhentos e Quarenta e Sete Mil, Novecentos e Cinqüenta e Seis Reais e Quarenta Centavos).

\subsection{A diferença entre a primeira e a segunda linha decisória}

A diferença dos valores encontrados, em relação ao total apurado nas duas linhas de decisão somente para as análises laboratoriais, pode ser expressa pela seguinte equação:

D.D.P2 $=$ Vt.P.D. - Vt.S.D.

D.D.P2 $=R \$ 736 \cdot 392,72-R \$ 547.956,40$ obtendo-se um valor de final de:

D.D.P2 = R\$ 188.436,32 (Cento e Oitenta e Oito Mil, Quatrocentos e Trinta e Seis Reais e Trinta e Dois Centavos).

D.D.P2 = Diferença decisória na priorização 2

Vt.P.D. = Valor total da primeira linha de decisão

Vt.S.D. $=$ Valor total da segunda decisão

\subsection{Investigação confirmatória - exemplos.}

"A etapa de investigação confirmatória encerra o processo de identificação de áreas contaminadas e tem como objetivo principal confirmar ou não a existência de contaminação e verificar a necessidade da realização de uma investigação detalhada nas áreas suspeitas, identificadas na etapa de avaliação preliminar. Desta forma, os resultados obtidos na etapa de investigação confirmatória são importantes para subsidiar as ações do órgão gerenciador ou órgão de controle ambiental na definição 
do responsável pela contaminação e dos trabalhos necessários para a solução do problema" GLOEDEN, 1999.

Segundo a metodologia (item 4.1.7) a confirmação de contaminantes em uma área suspeita, dá-se basicamente pela tomada de amostras e análises de solo e/ou água subterrânea em pontos estrategicamente posicionados.

Neste estudo, não será efetuada a confirmação de contaminação em nenhuma área, pois os procedimentos legais e as bases financeiras para se efetuar investigações confirmatórias em áreas comerciais/industrias ativas ou desativadas encontra-se em discussão em nível de diretoria na CETESB.

Entretanto como exemplo para se executar uma possivel investigação confirmatória, serão tomadas como exemplo quatro áreas cujas notas estão no intervalo de pontuação de 601 a 700 . Para se definir a localização dos pontos de amostragem de solo e águas subterrâneas para cada área foram utilizadas as informações de suas fichas cadastrais, item 9 (nove) denominado Croqui da área/modelo conceitual.

A seguir, no croqui das áreas $C 000355,1000302,1000313$ e 1000316 serão indicados quais os melhores pontos para se proceder uma investigação confirmatória baseada na Estratégia de amostragem número 4 (quatro) recomendada pela CETESB (vide quadro 4.1). 


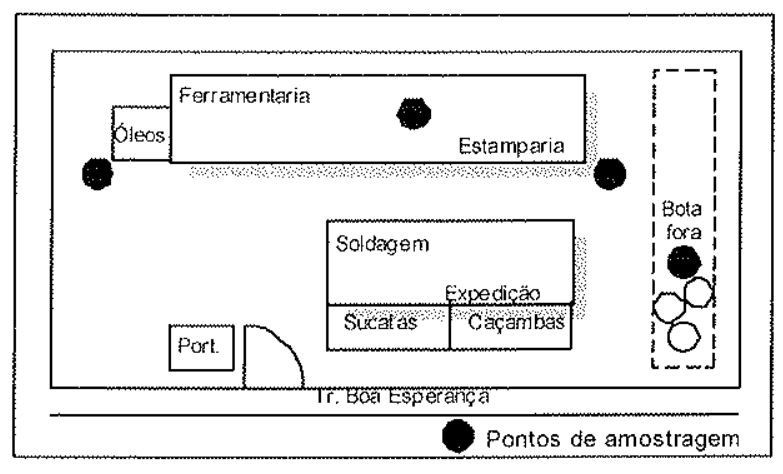

1000313

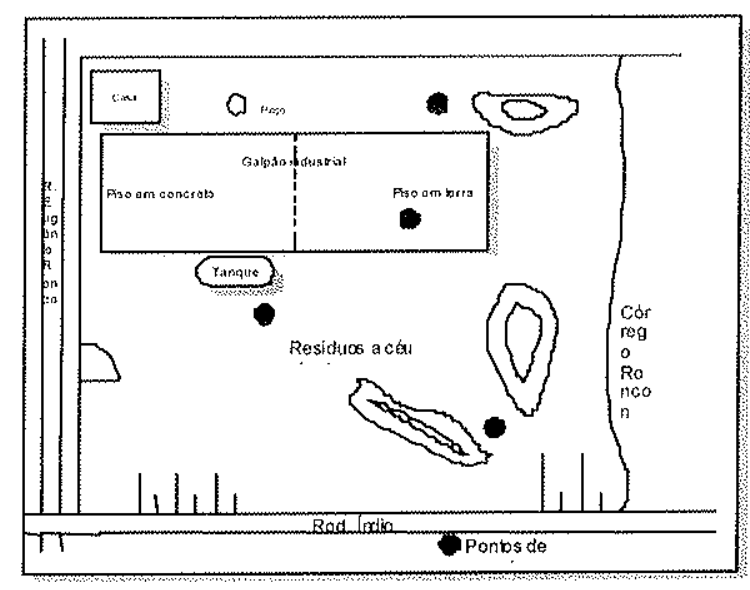

1000302
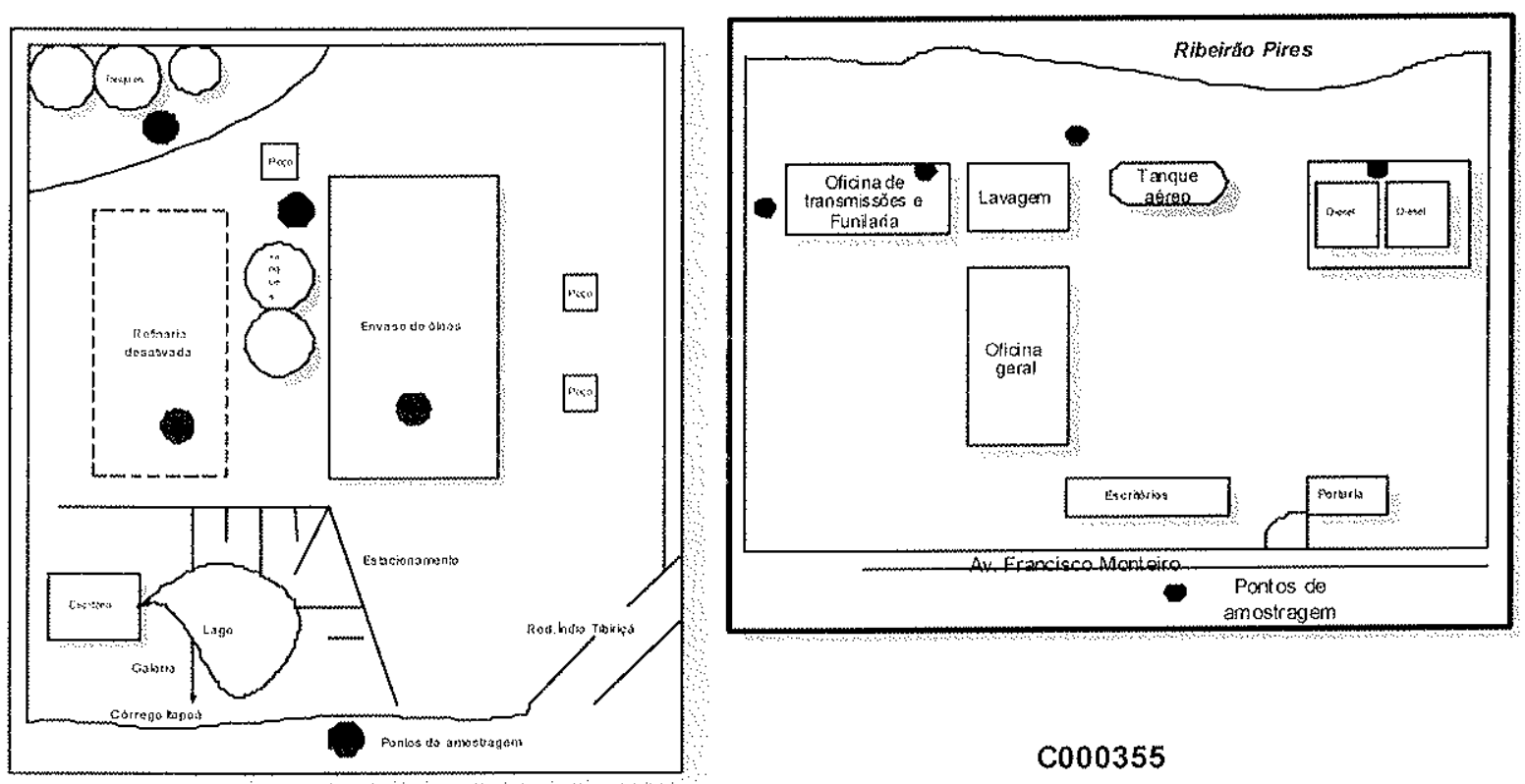

1000316 


\section{PROPOSIÇÕES}

O capitulo intitulado "proposições", têm o objetivo de fomentar subsídios para o desenvolvimento e aprimoramento do processo de identificação das áreas contaminadas, em áreas de manancial, em especial no município de Ribeirão Pires. Basicamente as propostas são sustentadas por observações tanto no transcorrer das avaliaçōes de campo como no levantamento bibliográfico efetuado. As propostas apresentadas foram subdivididas em relação a legislação, aos postos de serviços automotivo, as áreas industriais e à continuidade do estudo.

\subsection{Proposições em relação à legislação}

Ao disciplinar a ocupação do solo a lei 1172, segundo SPSMA (1997a), elencou os usos permitidos e os critérios para a implantação dos sistemas públicos de abastecimento de água, coleta e disposição de resíduos sólidos e de esgotos. As áreas de primeira categoria, ou de maior restrição, são aquelas situadas às margens das represas, dos rios e córregos, as áreas cobertas por matas, inundáveis e de grande declividade.

As áreas de segunda categoria correspondem ao restante das subbacias e são subdivididas em: Classe A (área urbana com densidade superior a 30 habitantes/ha) e Classe $B$ (áreas situadas no entorno daquelas consideradas urbanas e destinadas à expansão) e finalmente a Classe $C$ (as demais áreas, com densidade entre 6 habitantes/ha a 24 habitantes/ha). Na figura 7.1 serão demostradas as categorias de ocupação de solo e a densidade de habitantes por hectare. 


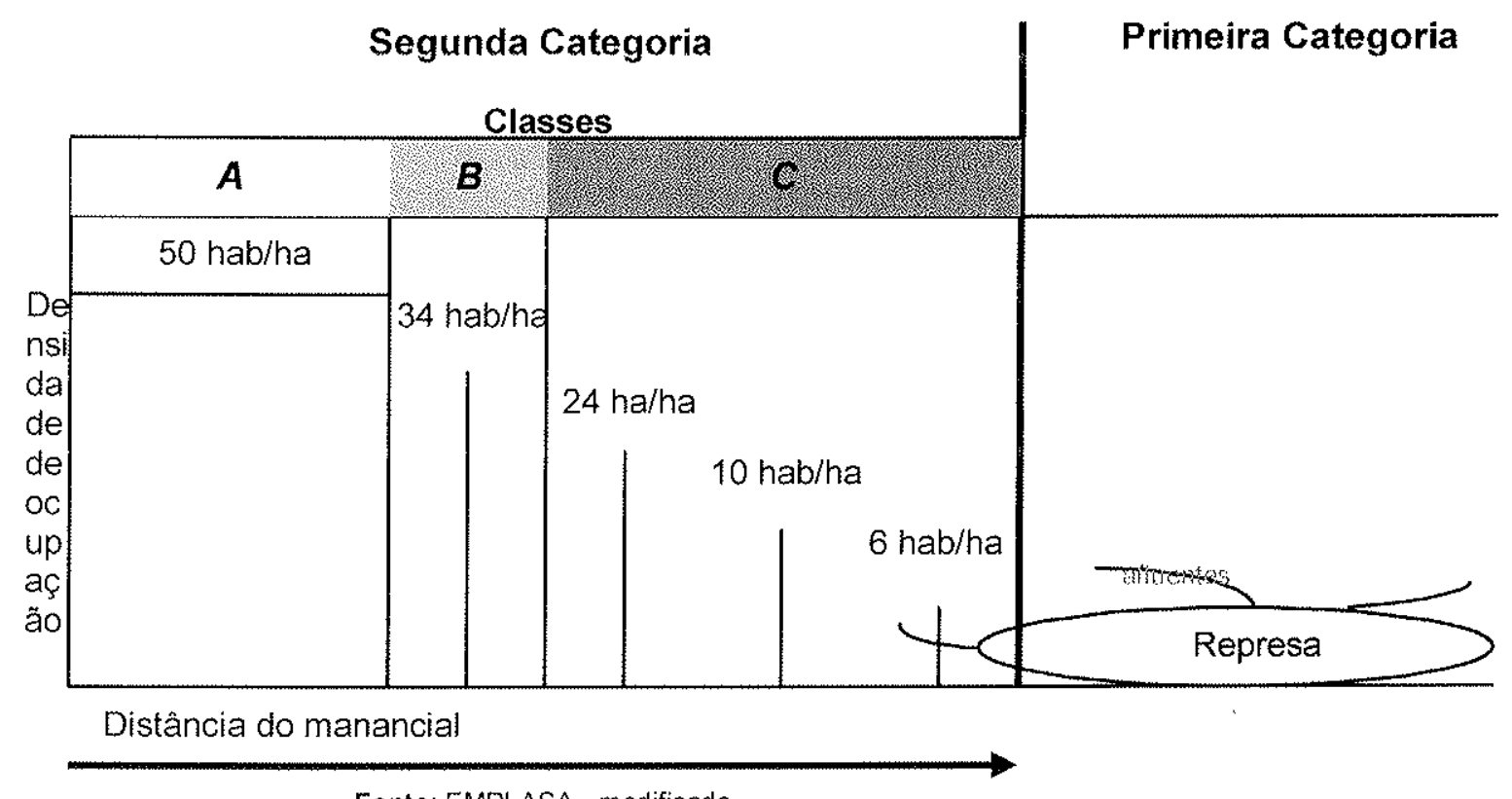

Fonte: EMPLASA - modificado

\section{Figura 7.1 As categorias de ocupação do solo.}

As dificuldades e conflitos, que os municípios que possuem $100 \%$ (cem por cento) de suas áreas inclusas em Área de Proteção dos Mananciais, como: Embu-Guaçu, Itapecerica da Serra, Juquitiba, Ribeirão Pires e Rio Grande da Serra, podem ser sintetizadas no capitulo: Diagnóstico preliminar, item: Proibição de indústrias, na publicação RIBEIRÃO PIRES (1997), onde mostra as dificuldades que o município vêm enfrentando desde que a lei 898 de 18/12/75 e ratificada pela 1172 de 17/11/1976 passaram a vigorar e estabeleceram os parâmetros de uso e ocupação do solo.

Com a proibição de instalação de indústrias nas áreas definidas como de $2^{\mathrm{a}}$ Categoria Classe C pela Legislação de Proteção aos Mananciais - onde, tradicionalmente, instalaram-se as indústrias no município e são encontradas as maiores áreas vazias da cidade, segundo RIBEIRÃO PIRES (1997) "originou grandes áreas sem usos definidos", ainda referenciando a publicação, no terceiro parágrafo reflete a extrema insatisfação para com as legislações vigentes: "Dada as condições existentes pode-se apontar a tendência de estagnação econômica aliada ao adensamento desordenado do município, se não forem adotadas novas alternativas de gestão urbana. Está em curso a revisão da legislação estadual que aponta para a possibilidade de adequação 
das normas à realidade existente, mas essa lei será insuficiente se não for acompanhada de outros mecanismos".

\subsubsection{Proposições:}

1. Propor emenda às Leis $9866 / 97$, que propóe uma nova política de mananciais e as Diretrizes e Normas para a Proteção e Recuperação das Bacias Hidrográficas dos Mananciais de Interesse Regional do Estado de São Paulo, em seu Capítulo III, denominado: Instrumentos de Planejamento e Gestão, no Artigo 11, incluir o Gerenciamento de áreas contaminadas como sistema de gestão ambiental e a Lei 9999/98, que altera a Lei № 9.472 (que dispõe sobre o zoneamento industrial na Região Metropolitana de São Paulo) e seja aplicada a metodologia do Gerenciamento de áreas contaminadas em áreas industriais e/ou comerciais desativadas, com vistas à investigação do passivo ambiental, em instalações situadas em áreas definidas como: Segunda Categoria, Classe $\mathrm{C}$ objetivando:

$\checkmark$ A revitalização de áreas desativadas e

$\checkmark$ Criação de um fundo de desenvolvimento e incentivo estadual para reuso de instalacões industriais elou comerciais desativadas em áreas de manancial.

$\Rightarrow$ Justificativa: A criação de um fundo de desenvolvimento e incentivo estadual para reuso de instalações industriais / comerciais desativadas em áreas de manancial, nos moldes do programa "Brownfields" desenvolvido nos EUA, no municipio de Ribeirão Pires visa além da reutilização das edificações já existentes, uma mudança de postura das autoridades estadual e municipal com vistas à geração de novos empreendimentos, negócios e empregos.

Com a adoção das etapas do Gerenciamento de áreas contaminadas, em uma dada área, o resultado para o município seria: 
A) O aval ou certificação do órgão ambiental estadual (CETESB) em relação ao passivo ambiental da área,

B) Escolha da área a ser revitalizada envolvendo e concientizando a população do município,

C) Formação de um novo conceito de negócios ou econegócios com forte apelo de marketing, aproveitando-se de sua localização geográfica, sua condição de estância turística, sua localização privilegiada em relação a RMSP e ao porto de Santos (com vistas à exportação) e a represa Billings,

D) Criação nessas edificações desativadas de produtos e serviços ligados ao meio ambiente, como: criação de polo cultural com ênfase em ciências ambientais estruturado junto à USP e universidades da região (nos níveis: técnico, de graduação e pós-graduação),

E) Atração de empresas ligadas ao setor de entretenimento, ecoturismo e indústria de material esportivo, desde que se enquadrem na legislação do zoneamento industrial vigente.

II. Reuso do solo: Como a lei $9999 / 98$ foi dirigida somente às áreas municipais denominadas ZUPI (zonas de uso predominantemente industrial) e que tenham sofrido descaracterização significativa do uso industrial, as outras faixas de uso ou zoneamento urbano, ficaram descobertas.

"Propor critérios para ocupação de edificações industriais e/ou comerciais desativadas, em áreas de $2^{a}$ Categoria Classe $C$, ao invés de se permitir a construção de novas edificações de mesmo perfil em áreas com cobertura vegetal "original" ou virgem, desde que haja a investigação confirmatória do passivo ambiental".

A proposta de reuso de áreas industriais/comerciais desativadas foi baseada em uma análise de custo-benefício feita pela Agência Federal de Meio Ambiente da Alemanha sobre a reutilização de áreas industrias desativadas (GRIMSKI, DOETSCH, RÜPKE (1998)), que visa a reutilização de edificações desativadas (industriais e/ou comerciais) com o objetivo de se atender: aos 
interesses: da legislação estadual, do município, das demandas dos investidores, das demandas ecológicas e da utilização das estruturas urbanas já existentes.

Os critérios descritos no estudo para a análise de custo-benefício de uma área a ser reutilizada em detrimento à ocupação de área "virgem" são; o Potencial da área (considerando-se os interesses do municipio), o Potencial de uso (considerando-se os interesses dos investidores) e o Valor da área (considerando-se as demandas ecológicas $e$ as estruturas urbanas). Os subcritérios de cada item quantificados, foram:

- Potencial da área: Tamanho (ha), Potencial de edificação (máximo edificável), Infra-estruturas (água, esgoto, energia, gás, telefone), Integração com o sistema viário e transporte público.

- Potencial de uso: Acesso a vias principais e auto-estradas, Localização (centro, bairro, periferia), Zoneamento urbano (uso do solo e suas restrições), Legislação vigente (planejamento urbano) e Atratividade (imagem da edificação no cenário urbano).

- Valor da área: O valor da área é subdividido em três categorias: Valor ecológico da área (interferências antrópicas no meio como impermeabilização, compactação do solo, relevo e tipo de aqüífero), Valor urbanístico (paisagem urbana, infraestruturas) e o Valor espacial da área (em relação ao desenvolvimento e planejamento urbano-regional).

- Custos para remediação (quando da confirmação de contaminação): são subdivididos em: custos de preparaçăo da área (topografia, levantamento histórico, avaliação preliminar, investigação confirmatória e detalhada, análise de risco), custos do processo de remediação (análise de custobenefício para a escolha do processo de remediação a ser empregado) e valor de venda futura da área. 


\subsection{Proposições para os Postos de serviço:}

Excetuando-se P000128, em todos os demais postos de serviço automotivo foi observado que as condições de impermeabilização dos pisos, tanto nas áreas de abastecimento, na área de lavagem e troca de óleo dos veículos e áreas próximas àos bocais de enchimento dos tanques de combustivel fortam consideradas ruins, pois apresentavam: rachaduras, remendos, áreas com recalques, presença de contaminantes e tipos de revestimento inadequados.

Outro fato que observado é os efluentes gerados das áreas de lavagem, lubrificação, troca de óleo e lavagem do piso da área de abastecimento, ou são lançados na rede de esgoto municipal ou são descartados na rede de água pluvial ou descartados diretamente nas águas superficiais, vale ressaltar que GLOEDEN (1999) em sua avaliação de campo no reservatório Guarapiranga observou os mesmos problemas.

7.2.1 Proposição: Propor aos postos de serviço do municipio de Ribeirão Pires:

A) Enquadramento à Resolução do Conselho Nacional de Meio Ambiente CONAMA, número: 273 de 29 de novembro de $2000 \mathrm{e}$

B) Realização de investigação confirmatória do passivo ambiental em todas as áreas.

\subsection{Proposições para as Áreas industriais:}

As propostas de ação em um ambiente industrial, quer em relação às trocas de produtos, quer em relação às políticas de produção, necessariamente estão condicionadas ao seu custo-benefício. Ao propor uma determinada política de ações o empresário ou a organização têm sempre em mente o aspecto financeiro, portanto as proposições que serão apresentadas são exemplos de ação e não foram quantificadas financeiramente.

As propostas de ação nas áreas industriais foram norteadas por: a região de interesse estar completamente inserida em Área de Proteção aos Mananciais e nas atividades potencialmente contaminadoras, aos bens a proteger priorizados (item 5.6), à 
substituição dos grupos contaminantes: a) Ácidos, bases, anidridos, b) Solventes orgânicos halogenados e c) Compostos inorgânicos de elevada toxicidade como Cianetos, Fluoretos e Cromatos.

\subsubsection{Proposições:}

Cada indústria interessada deve apresentar à CETESB, grupo de Prevenção à Poluição, Programa de $\mathrm{P} 2$, uma declaração de intenções para substituir produtos utilizados na produção, com intenção de se gerar menor volume de resíduos e impacto ambiental, com vistas à aquisição de linha de financiamento com juros subsidiados pelo: Programa de Controle da Poluição Industrial - PROCOP.

$\Rightarrow$ Justificativa: As indústrias localizadas em área de manancial, pertencentes à Primeira e Segunda Categorias (classes $\mathrm{B}$ e C), possam receber incentivo para procederem a troca de produtos e adquirirem equipamentos para se efetuar os denominados "pré-tratamentos, verdes, em peças metálicas", segundo QUÍMICA E DERIVADOS (1998) podem ser utilizados os seguintes produtos:

- Na decapagem e polimento verdes: No preparo das peças metálicas, nas etapas de decapagem e polimento (desoxidação de metais) de peças pode ser utilizado o peróxido de hidrogênio $\left(\mathrm{H}_{2} \mathrm{O}_{2}\right)$, em substituição aos ácidos cianídrico e nítrico. Os ganhos, no caso do ácido cianídrico será a não necessidade de sua oxidação com hipoclorito de sódio e quanto ao ácido nitrico com a utilização de $\mathrm{H}_{2} \mathrm{O}_{2}$, obtêm-se uma menor geração de lodo na unidade de tratamento de águas dos banhos de decapagem.

- No desengraxe biológico: Em alternativa à utilização dos solventes halogenados, há tendência de utilização de produtos ou formulações com tensoativos não-iônicos etoxilados ou aniônicos, com opções de biodegrabilidade total ou parcial. Outra alternativa é o tratamento do sistema biológico, que consiste em se desengraxar peças metálicas por imersão ou lavagem utilizando-se chuveiros onde o líquido de desengraxe têm sua temperatura e pH controlados, ao mesmo tempo o tanque de trabalho recebe 
uma carga de emulsificantes e umectantes. Essa combinação cria condições ideais para que colônias de bactérias aeróbicas, previamente adaptadas e colocadas no tanque, se reproduzam e comecem a metabolizar o óleo e outras substâncias que estão na superfície das peças, transformando-as em materiais solúveis, gás carbônico e água.

\subsection{Proposição para continuidade do estudo}

Ao se propor a continuidade do presente estudo da identificação de áreas contaminadas, no município de Ribeirão Pires pretende-se:

A) Dar continuidade ao processo de identificação de áreas contaminadas pela execução da Investigação confirmatória em todas as áreas suspeitas priorizadas, também denominada como primeira linha de decisão (item 6.2.1) ou

B) Realizar Investigação confirmatória nas áreas suspeitas priorizadas na segunda linha de decisão (item 6.2.2) ou

C) Realizar Investigação confirmatória nas áreas suspeitas "desativadas";

D) Nas áreas contaminadas identificadas, após a investigação confirmatória, dar início ao Processo de recuperação de áreas contaminadas (item 4.1);

E) Ampliar as tabelas de atividades (Anexo II), com vistas às investigações: confirmatória e detalhada para todas as atividades potencialmente contaminadoras dos solos e águas (superficiais e subterrâneas) e

F) Realizar o Gerenciamento de áreas contaminadas (CETESB (1999)) em todos as Áreas de Proteção dos Mananciais da Região da Grande São Paulo e as principais bacias hidrográficas do Estado de São Paulo. 


\section{CONCLUSÃO}

Ao se implementar o estudo de identificação, no município de Ribeirão Pires, constatou-se que vários autores como CUNHA (1997), SANCHÉZ (1998) e GLOEDEN (1999) em suas conclusões são precisos no que se refere ao tema áreas contaminadas. Todos apontam a necessidade de que o poder público possa dispor de metodologia para avaliar, cadastrar, investigar, propor remediação, em áreas suspeitas de contaminação e contaminadas, com vistas à revitalização das mesmas.

Atendendo a essa demanda foi instituído, pela CETESB por meio de resolução de diretoria, o "Gerenciamento de áreas contaminadas". A metodologia foi adotada como procedimento, pois possibilita ao estado de São Paulo a edificação de um sistema de gestão ambiental que possibilite ações proativas, corretivas e preventivas, para com áreas contaminadas.

Os resultados obtidos na identificação de áreas industriais, comerciais e de disposição de resíduos, tanto em unidades ativas como em desativadas, são extremamente importantes para se quantificar o impacto ambiental desses processos na região de interesse, pois as informações contidas nos processos de licenciamento somadas às obtidas nas inspeções de campo, proporcionam ao gestor (que pode ser um município, estado, ...) uma ferramenta adequada para se promover a leitura do passivo ambiental dessas atividades.

A preocupação de se conhecer o passivo ambiental nas áreas avaliadas, como medida preventiva, justifica-se pelo fato de que em visita recente à região de interesse, foi notado que a ocupação de áreas industriais e comerciais desativadas hoje são reutilizadas por diferentes segmentos ou modelos de ocupação.

Como exemplo, podemos citar as áreas $\mathrm{C} 000232$ e a área 1000443. Na primeira, que comercializava combustíveis no atacado, em entrevista com moradores do local, mencionou-se que a área foi desativada e devido a sua localização, logo instalou-se 
um restaurante e na segunda área, o galpão da galvanoplastia foi alugado para uma instituição religiosa.

Vale salientar que em ambos os casos não foi apresentado ao órgão ambiental estadual, nenhum estudo de avaliação do passivo ambiental nessas áreas.

Exemplos como esses estão cada vez mais presentes no cotidiano das cidades, principalmente as que formam a RMSP, onde o êxodo das indústrias para o interior e outros estados a partir da década de oitenta deixa para traz, além dos problemas sociais, o legado do passivo ambiental. Vale ressaltar que somente quando há a fusão de indústrias é que o passivo dessas áreas são avaliados, com a intenção de se descontar, do valor inicialmente arbitrado, o custo de investigação e remediação do local.

Os resultados obtidos na execução do processo de identificação de áreas contaminadas, no município de Ribeirão Pires, mostraram-se de fácil administração, no entanto há a necessidade de se efetuar o desenvolvimento das listas de atividades, principalmente quando se avalia uma área industrial e/ou comercial desativada, principalmente no item relacionado a se estimar os grupos contaminantes, ou substâncias que foram utilizadas nessa área.

As dificuldades de se efetuar as avaliações de campo, em indústrias desativadas, foram consideradas crônicas em duas situações: quando não se detém os dados históricos da área e quando não há a possibilidade de se acessar o local.

A panorâmica total da região de interesse somente será completa quando as informações das áreas avaliadas, nesse estudo, puderem ser confirmadas e o processo de recuperação de áreas contaminadas ser aplicado nas áreas classificadas como contaminadas, e aplicar a metododologia do gerenciamento em todas as demais atividades potencialmente contaminadoras que ainda não foram diagnosticadas no município. 
Com os valores dos custos diretos do processo de identificação ou aqueles obtidos utilizando-se as pontuações que o Cadastro de áreas contaminadas proporciona, pode o município de Ribeirão Pires utilizá-los na obtenção de recursos financeiros junto a fontes nacionais ou internacionais para que as propostas contidas neste estudo, em seu item 7, possam ser realizadas de maneira pioneira em nosso País. 


\section{REFERÊNCIAS BIBLIOGRÁFICAS}

AB SABER, A. N. Províncias Geológicas e Domínios Morfoclimáticos no Brasil. In Geomorfologia, No 20. IG/USP, São Paulo. 1970.

ALTLASTENEXPLORER. Schlütersche Vergsanstat und Druckerei. GmbH, Hannover, 1997. "Software".

AMERICAN SOCIETY FOR TESTING AND MATERIAL. Cleanup criteria for contaminated soil and ground-water - DS 64. Anthony J. Buonicore Editor. West Conshohocken, 1996.

ANDRADE, A. C. Sistemas de avaliação de prioridades para recuperação de áreas contaminadas por resíduos perigosos. São Paulo, 1996. 126p. Dissertação (Mestrado). Faculdade de Saúde Pública, Universidade de São Paulo.

ASSOCIAÇÃO BRASILEIRA DAS INDÚSTRIAS QUIMICAS - ABIQUIM. Anuário da indústria química brasileira. São Paulo, ABIQUIM. 1995, 334p.

ASSUMPÇÃO, R. M. V., MORITA, T. Manual de soluções, reagentes e solventes; padronização, preparação, purificação. São Paulo, Ed. Edgard Blügher. 1968, $627 p$

BEAULIEU, $M$. The use of assessment and risk management in the revitalization of brownfields in North America. In: CONTAMINATED SOIL'98, Proceedings. London, Thomas Telford, 1998, V1, p. 51-59.

BELLIA, V. Introdução à Economia do Meio Ambiente. Brasília, IBAMA. 1996, $262 p$.

BITAR, O. Y., ORTEGA, R. D. Gestão Ambiental in Geologia de Engenharia.. São Paulo. A.B.G.E. 1997, p 504 a 508.

BORGER, F. G. Valoração econômica do meio ambiente: aplicação da técnica avaliação contingente no caso da bacia do Guarapiranga, São Paulo. 1995. p 37-40. Dissertação (Mestrado). Programa de Ciências Ambientais, Universidade de São Paulo..

BOULDING, J. R. Practical Handbook of Soil, Vadose zone and Ground-water Contamination, Assessment, Prevention and Remediation. Boca Raton, Lewis Publ. 1995, 947p

BUTLER, B. E. Consultation with National Experts: managing contaminated land. In a Training resouce package: Risk management of contaminated industrial land. New York, UNEP. 1996. p 1:5-13. 
BRAILE, P. M. Dicionário de poluịção industrial e ambiental. Rio de Janeiro, Sesi DN/COHISI. 1983, 409p.

CAETANO, P. M. D. Gestão da qualidade da água e mercados de quotas de poluição. São Paulo. 1999. Dissertação (Mestrado), Escola Politécnica, Universidade de São Paulo.

CÂMARA TÉCNICA DA INDÚSTRIA, CePM - Billings. Programa de Recuperação Ambiental da Bacia do Rio Grande - Levantamento de dados de indústrias situadas no braço do Rio Grande, Represa Billings, para controle de efluentes e ficalização em área de proteção de mananciais, $v-$ vip. São Paulo, CePM - BILLINGS. 1998, 15p.

CARDOSO, A. Manual de galvanostegia e de galvanoplastia. Venda Nova, Livraria Bertrand. s.d. 244p.

COMPANHIA DE PESQUISA DE RECURSOS MINERAIS - CPRM. Projeto Santa Isabel / Mogi das Cruzes / Mauá - Relatório Final, v.1. CPRM, São Paulo. 1990.

COMPANHIA DE TECNOLOGIA DE SANEAMENTO AMBIENTAL. - CETESB. Manual de áreas contaminadas. CETESB, São Paulo. 1999.

COMPANHIA DE TECNOLOGIA DE SANEAMENTO AMBIENTAL - CETESB M5083. Limpeza de superfícies metálicas por meio de solventes. São Paulo, CETESB. 1978, 8p.

COMPANHIA DE TECNOLOGIA DE SANEAMENTO AMBIENTAL - CETESB NT25. Nota técnica sobre tecnologia de controle de rerefino de óleo lubrificante usado. São Paulo, CETESB. 1992, 26p.

COMPANHIA DE TECNOLOGIA DE SANEAMENTO AMBIENTAL - CETESB NT16. Nota técnica sobre tecnologia de controle de galvanoplastias. São Paulo, CETESB. 1990, 5p.

COMPANHIA DE TECNOLOGIA DE SANEAMENTO AMBIENTAL - CETESB - 85. Tratamento de resíduos líquidos da pequena indústria - galvanoplastias. São Paulo, CETESB. 1985, 83p.

COMPASS RESOURCE MANAGEMENT Inc. Total Cost Assessment Guidelines. The BC Ministry of Environment, Lands \& Parks, Canada. 1997, 132p.

CUNHA, R. C. de A. Avaliação de Risco em Áreas Contaminadas por Fontes Industriais Desativadas - estudo de caso. São Paulo, 1997, 152p. Tese (Doutorado), Instituto de Geociências, Universidade de São Paulo.

DANISH ENVIRONMENTAL PROTECTION AGENCY. Ad Hoc International Working Group on Contaminated Land, report of meeting in Amsterdam. Copenhagen, DEPA. 1997, 80p. 
DOESTSCH, P.; RÜPKE, A. Revitalisierung von altlastandorten versus ilnaspruchnahme von naturflächen. Berlin, UBA. 1998, (UBA-FB 97-111).

EUROPEAN ENVIRONMENT AGENCY (EEA). Environment in the European Union at the turn of the century - appendix to the summary. facts and findings per environmental issue. Luxemburg, O.O.P.E.C. 1999. 44p.

FETTER, C.W. Contaminant hidrogeology. New York, Macmillan Publishing Company, 1993.

FUNDAÇÃO SISTEMA ESTADUAL DE ANÁLISE DE DADOS - SEADE. Anuário estatístico do Estado de São Paulo.. São Paulo, SEADE. 1997. 375p

FUNDO ESTADUAL DE RECURSOS HÍDRICOS - FEHIDRO. Manual de Procedimentos Operacionais. São Paulo, COFEHIDRO. 1998, 6p.

GARGALLO, J. C. Diccionario de química y de productos químicos. Barcelona, Ediciones Ômega. 1959, 995p.

GLOEDEN, E. Gerenciamento de áreas contaminadas na bacia hidrográfica do reservatório Guarapiranga. São Paulo. 1999. 225p. Tese (Doutorado), Instituto de Geociências, Universidade de São Paulo

GRIMSKI, D.; DOESTSCH, P.; RÜPKE, A. Brownfields versus Greenfields Sites under Economic and Long Term Environmental Considerations in Contaminated Soil'98, Proceedings. London, Thomas Telford, 1998, p 651-660.

HAWLEY, G. G. The condensed chemical dictionary. New York, VNR Co. 1971. $971 p$

HAZARDOUS MATERIALS TRAINING and RESEARCH INSTITUTE - HMTRI. Site characterization, sampling and analysis. New York, VNR. 1997, p 3-7.

HIGGINS, T. Pollution prevention handbook. Boca Raton, Lewis Publ. 1995, 533p.

HOFFMAN, R. Administração da empresa agrícola. São Paulo, Pioneira. 1987, p234-235.

INSTITUTO BRASILEIRO DE GEOGRAFIA E ESTATISTICA - IBGE. Diagnóstico Brasil: a ocupação do território e o meio ambiente. IBGE, Rio de Janeiro. 1990. 170p.

IHOBE - SOCIEDAD PÚBLICA DE GESTIÓN AMBIENTAL. Plan Director para la Proteccion del Suelo. Lankopi, C.A.P.V. 1994, 130p.

IHOBE - SOCIEDAD PÚBLICA DE GESTIÓN AMBIENTAL. Criterios ambientales para la recuperacion de ruinas industriales.. Lankopi, C.A.P.V. 1998. 167p 
IHOBE - SOCIEDAD PÚBLICA DE GESTIÓN AMBIENTAL. Estudio histórico y diseño de muestreo. Lankopi, C.A.P.V. 1998, 73p.

INSTITUTE for RESPONSIBLE MANAGEMENT, Inc - IRM. Reclaiming brownfields for parks and open space: Three pilots' experiences with alternative land uses. New Jersey, IRM. 1996. V1. Issue 3.

KOVALICK, W.W \& KINGSCOTT, J. Progress in clean-up and technological developments in U.S. Superfund Program 1995). In: CONTAMINATED SOIL'95, Maastricht, 1995. Proceedings. Dordrecht, The Reserch Center Karlsruhe (FZK) \& Netherlands Organization for Applied Scientific Research TNO, 1995, v. 1, P. 29-38.

KYAS, A.; JAGGY, M. Managing Risks of Contaminated Sites - The point of view of a banker versus the point of view of an engineer in Contaminated Soil'98, Proceedings. London, Thomas Telford. 1998, p 711-716.

LaGREGA, D. M.; BUCKINGHAN, P. L.; EVANS, J. C. Hazardous Waste Management. New Jersey, McGraw Hill. 1994, p 361-376, 903-904

LEE, R.T. Comprehensive Environmental Response, Compensation and Liability Act. In: Thomas F.P. Sullivan. Environmental Law Handbook. Fourteenth Edition, Rockville, MD, 1997. p. 430-480.

MAcDOWELL, S. F.; CORREA S. F. Meio Ambiente e o Mercado Financeiro in IV Encontro Nacional sobre Gestão Empresarial e Meio Ambiente. São Paulo. 1997.

MARTIN, I.; LOWE, M.; HERBERT, S. The Use of Cost Benefit Analysis in Selecting Remedial Options for Contaminated Land in Contaminated Soil'98. Proceedings. London, Thomas Telford. 1998, p 1153-1154.

MINISTERIUM FÜR UMWELT, RAUMORDNUNG UND LANDWIRTSCHAFT DES LANDS NORDRHEIN-WESTFALEN. (MURL). Hinweise zur Ermitlung und Sanierung von Altlasten. 2. Auflage, 2. u., 3. Lieferung. Nordrhein-Westfalen. Loseblattsammlung. 1993.

NAVAL AIR STATION - Patuxent River - NAS. Proposed remedial action plan, sites 6 and $6 a-$ Bohneyard operable unit 1 - soil. 2000, 11p. Maryland. (www.nawcad.navy.mil/environmental).

NEIVA, J. Conheça o petróleo. Rio de Janeiro, Expressão e Cultura. 1993, p103118.

NEWMOA - THE NORTHEAST WASTE MANAGEMENT OFFICIALS' ASSOCIATION. Improving your competitive position: strategic and financial assessment of pollution prevention investiments - training manual. Boston, NEWMOA. 1998, 81p. 
PALMER, M. C. Principles of Contaminant Hidrogeology, Boca Raton, Lewis Publ. 1996, p26-27.

PANKOW, J. F.; CHERRY, J. R. Dense chlorinated solvents and other DNAPLs in groundwater. Ontario, Waterloo Press. 1995. 513p..

PEREIRA, N. Análise de risco ambiental de processo siderúrgico. São Paulo, 1998, 157p. Tese (Doutorado). Faculdade de Saúde Pública, Universidade de São Paulo.

QUÍMICA E DERIVADOS. Tratamento de superfícies, № 362. São Paulo. Ed. QD. $\mathrm{Jul} / 1998, \mathrm{p} 10$.

RIBEIRÃO PIRES - A Sua Cidade. Fórum Desenvolvimento Sustentado, Prefeitura Municipal de Ribeirão Pires, $\mathbf{N}^{0} \mathbf{0 1}$. Abr/1997.

RICHARDSON, M. L., GANGOLLI, S. The dictionary of substances and their effects. Cambridge, The Royal Society of Chemistry. 1996, 7V.

ROCCA, A. C. C. et al. Resíduos sólidos industriais, São Paulo, CETESB, 1993, $233 p$.

SÁNCHEZ, L. E. A Desativação de Empreendimentos Industriais: um estudo sob passivo ambiental. São Paulo, 1998, 176p. Tese de Livre Docência, Escola Politécnica, Universidade de São Paulo.

SANDEN, J. Financing Clean-up of Contaminated Sites in the New Federal Sates in Contaminated Soil'98, Proceedings. London, Thomas Telford. 1998, p12431244.

SÃO PAULO (ESTADO) - SECRETARIA DE ESTADO DO MEIO AMBIENTE (SPSMA). Financiamento para o Setor de Resíduos Sólidos.. São Paulo, CETESB. 1997a, 30p

SÃO PAULO (ESTADO) - SECRETARIA DE ESTADO DO MEIO AMBIENTE (SPSMA). Financiamento para o Setor de Saneamento Básico. São Paulo, CETESB. 1997b, 38p

SÃO PAULO (ESTADO) - SECRETARIA ESTADUAL DO MEIO AMBIENTE (SPSMA/ CETESB). Curso de licenciamento ambiental para os setores de saneamento e recursos hídricos. São Paulo, CETESB. 1998, 299p

SÃO PAULO (ESTADO) - SECRETARIA DE ESTADO DO MEIO AMBIENTE (SPSMA). Instrumentos Econômicos e Financeiros.. São Paulo, CETESB. 1998a, 257p

SÃO PAULO (ESTADO) - SECRETARIA DE ESTADO DO MEIO AMBIENTE (SPSMA). Inventário de Fontes Nacionais e Internacionais de Cooperação para Projetos Ambientais. São Paulo, CETESB, 1998b, 50p 
SÃO PAULO (REGIÃO METROPOLITANA) - EMPRESA METROPOLITANA DE PLANEJAMENTO DA GRANDE SÃO PAULO S/A - EMPLASA. Sistema cartográfico metropolitano. Levantamento aerofotogramétrico. São Paulo, 1992. Escala 1:10.000. folhas 4211, 4332, 4333, 4334, 4335, 4336.

SÄO PAULO (REGIÃO METROPOLITANA) - EMPRESA METROPOLITANA DE PLANEJAMENTO DA GRANDE SÃO PAULO S/A - EMPLASA. Carta geológica da região metropolitana da grande São Paulo. São Paulo, 1980. Escala 1:100.000.

SHEREVE, R. N.; BRIN JR., J. A. Indústrias de processos químicos.. Rio de Janeiro, Guanabara. 1980. $4^{a}$ edição. $717 p$

SHINELDECKER, C.L. Handbook of Environmental Contaminants: A Guide for Site Assessment. Chelsea, Michigan, Lewis Publishers, 1994.

SYMS, P. M. The Redevelopment of Contaminated Land for Housing Use in Contaminated Soil'98, Proceedings. 1998, p 671-679. London, Thomas Telford,.

TROSTER, R. L.; MOCHÓN, F. Introdução à economia, São Paulo, Makron Books,. 1994, 391p.

UNITED STATES ENVIRONMENTAL PROTECTION AGENCY - USEPA. Handbook - Ground water and wellhead protection. EPA/625/R-94/001. Washington, DC, Office of research and development, Office of water, 1994.

UNITED STATES ENVIRONMENTAL PROTECTION AGENCY - EPA/Bro Region III - brownfields. Industry profile fact sheets. 2000. 32p. INTERNET. (http://www.epa.gov/reg3hwmd/brownfld/2.

UNITED STATES ENVIRONMENTAL PROTECTION AGENCY - EPA/Bro - Office of solid waste and emegency response. The brownfields economic redevelopment initiative. EPA 500-F-98-250. Washington, DC. 1998. INTERNET. (www.epa.gov/brownfields).

UNITED STATES ENVIRONMENTAL PROTECTION AGENCY - EPA/BroB - Office of solid waste and emergency response. Targeted brownfields assessments. EPA 500-F-98-251. Washington, DC. 1998.

UNITED STATES ENVIRONMENTAL PROTECTION AGENCY - EPA/Bro solid waste and emergency response. Brownfields success stories: Buffalo, New York: From polluted steel graveyard to thriving tomato farm. INTERNET. (www.epa.gov/sweropsps/bf/html-doc/ss buffalo.htm.) 1998.

VALLE, M. A. Diagnóstico da relação indústria e meio ambiente no município de Santo André, com ênfase nos recursos hídricos. São Paulo, 1997, 109p. Dissertação (Mestrado)., Instituto de Geociências, Universidade de São Paulo. 
Anexo I

Ficha cadastral utilizada em campo, na etapa de avaliação preliminar. 

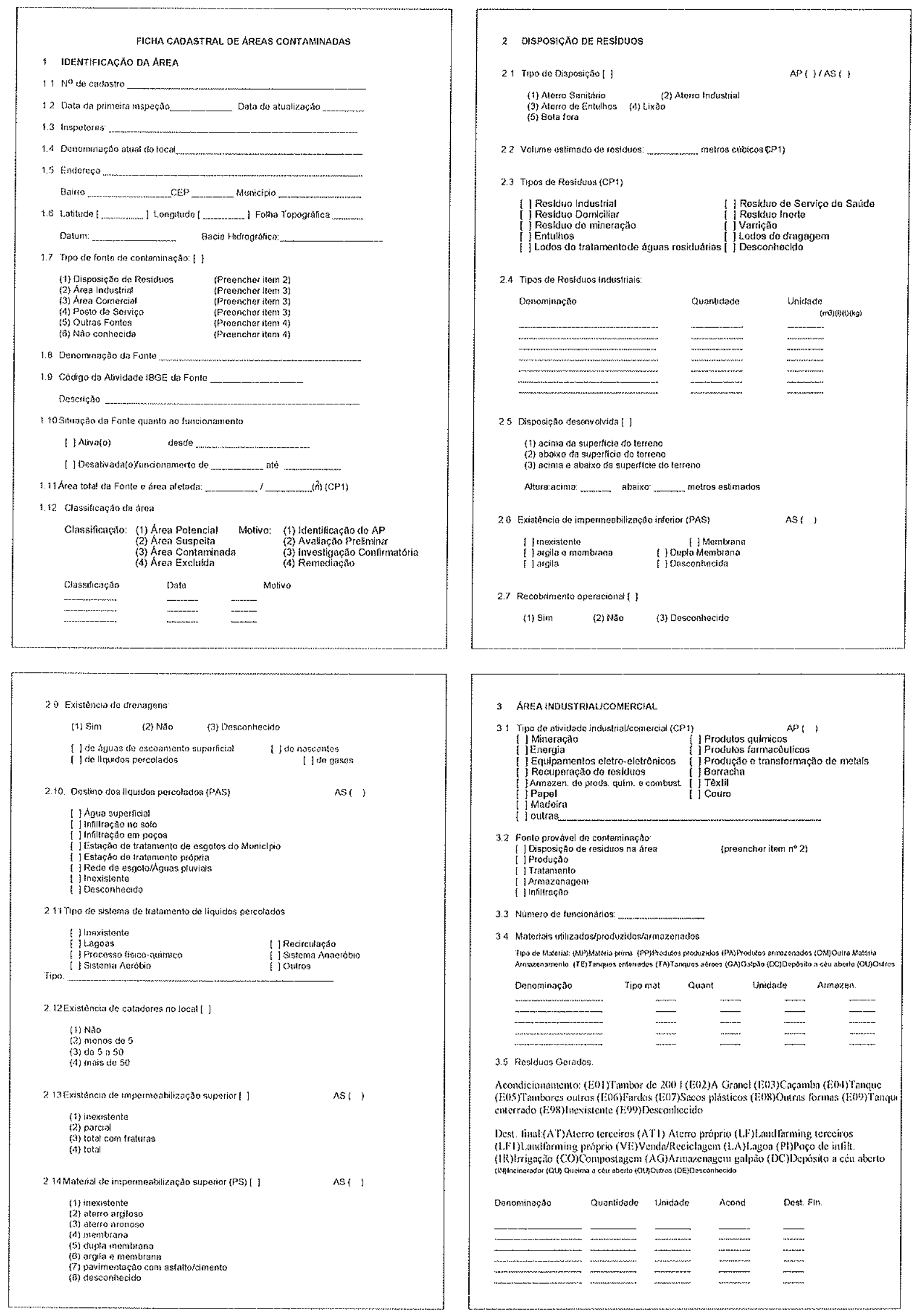

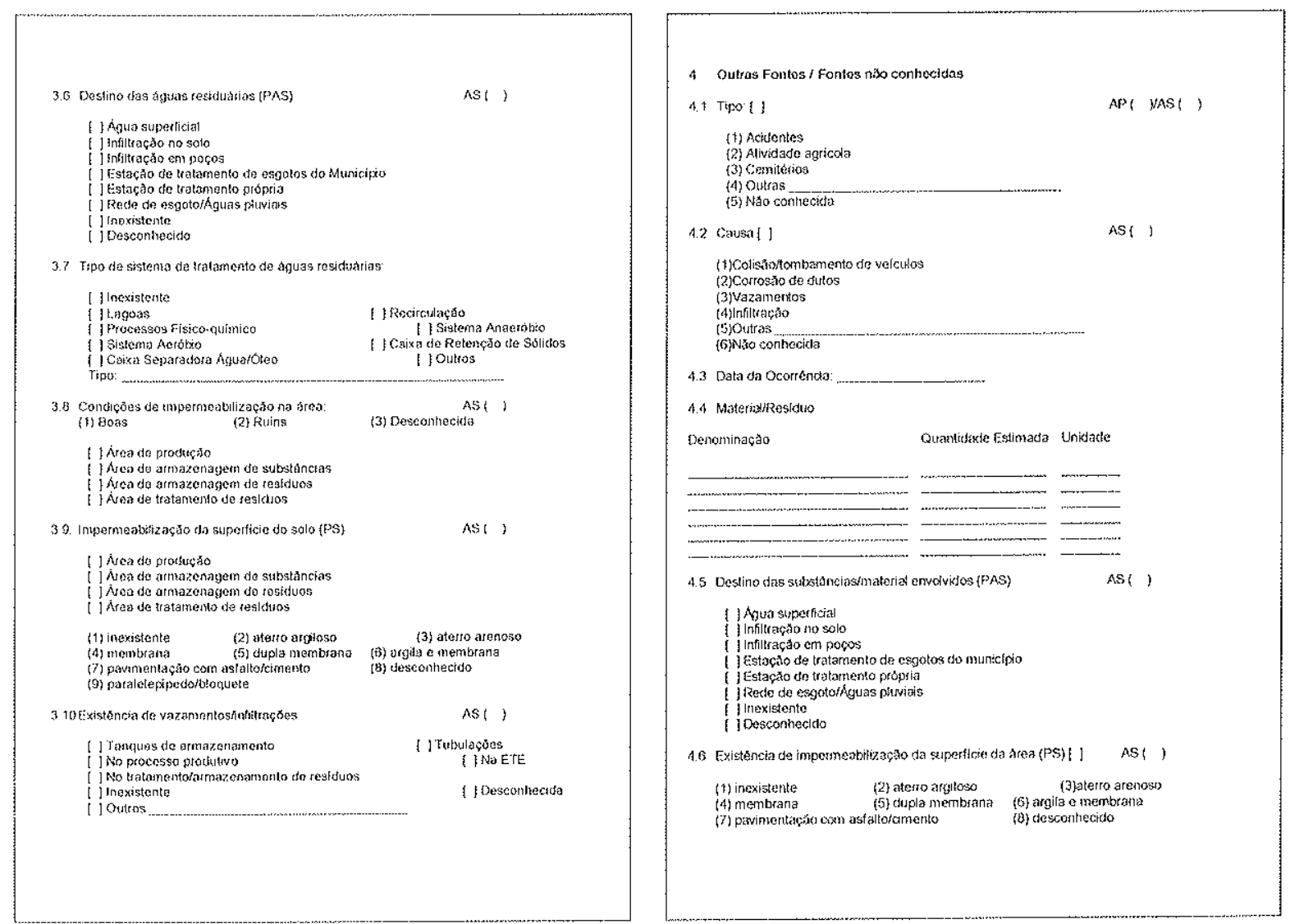

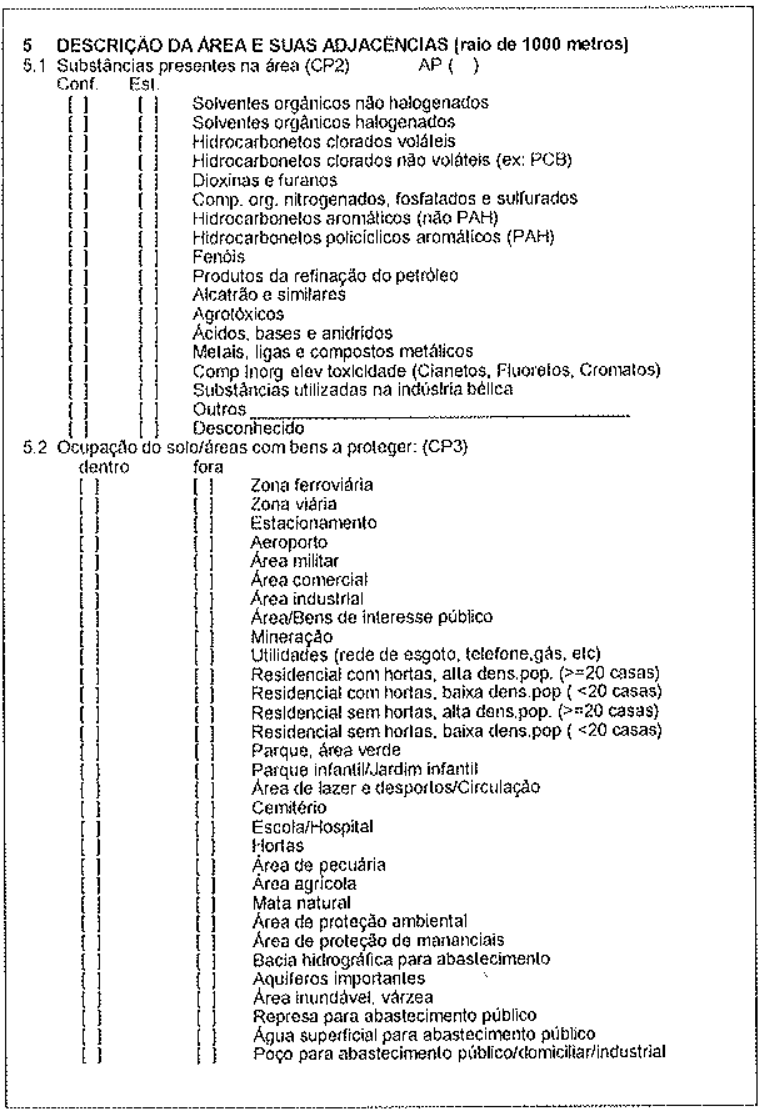

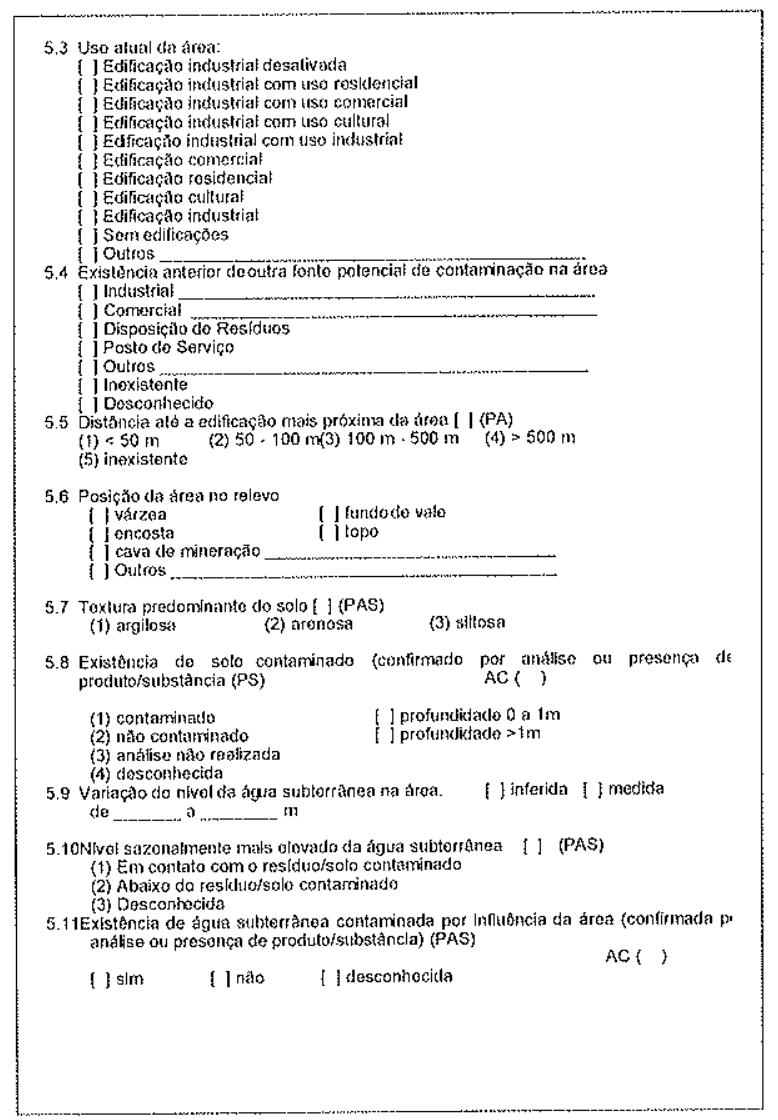



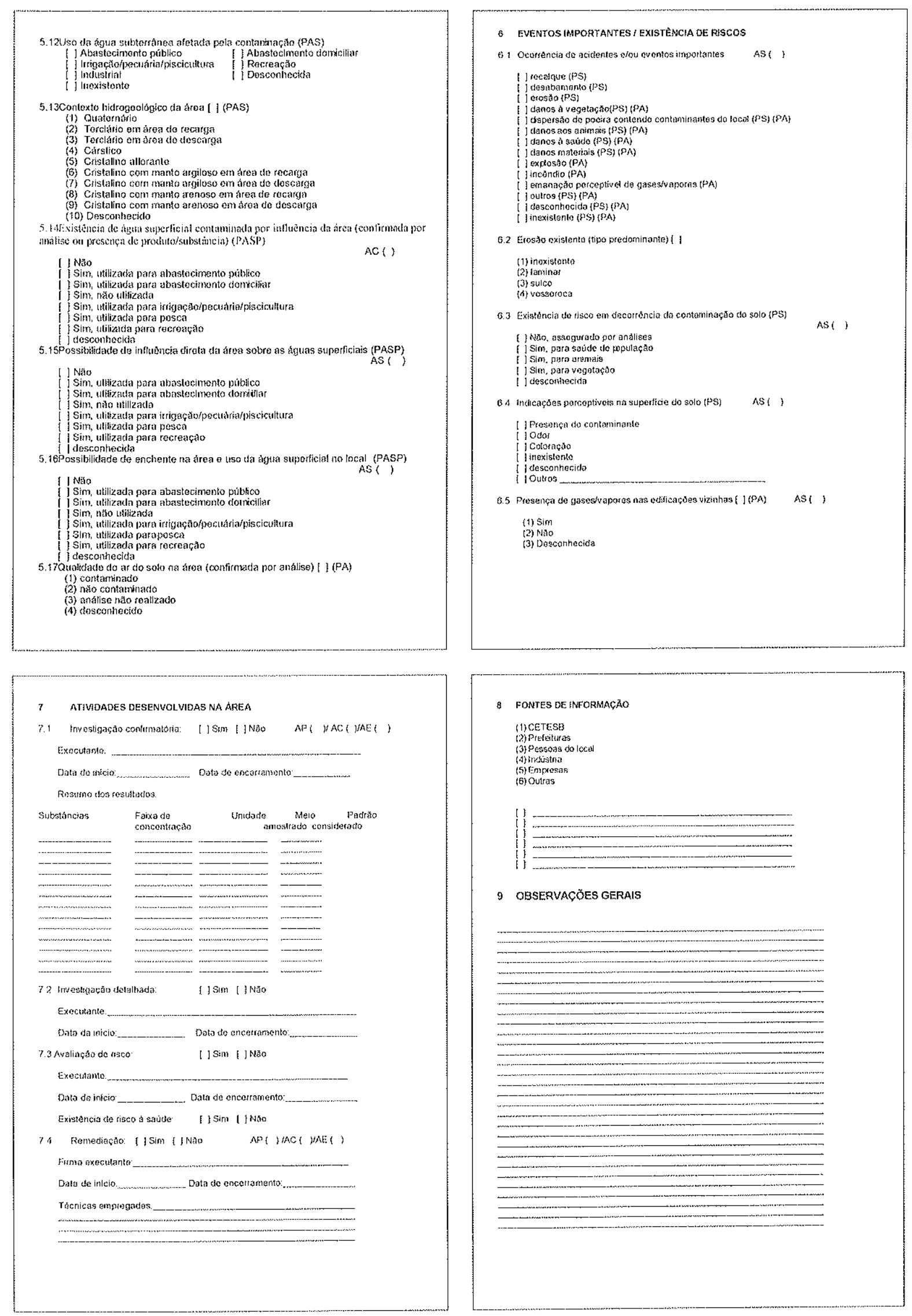
10 CROQUI DA AREA / MODELO CONCETUAL

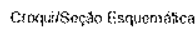

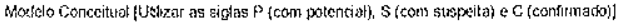

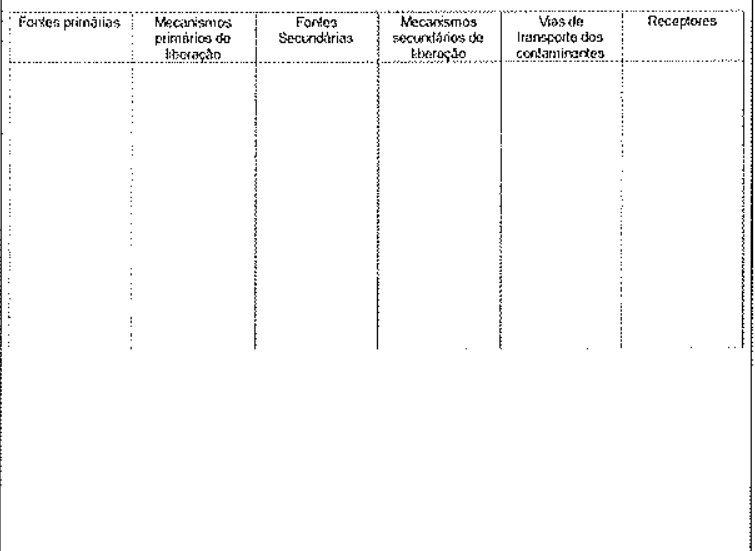

11. MAPA DE LOCALZZACKOO DAAREA 
Anexo II

Tabela de atividades 


\begin{tabular}{|c|c|c|c|}
\hline Substância & Gr. Contaminante & Fórmula & Uso \\
\hline Ácido Crômico & Ácido & $\mathrm{CrO}_{3}$ & Capeamento, limpeza \\
\hline Ácido Nitrico & Ácido & $\mathrm{HNO}_{3}$ & Galvânica, corrosão \\
\hline Ácido oxálico & Ácido & $\mathrm{HOOCCOOH} \mathrm{H}_{2} \mathrm{O}$ & Limpeza de metais \\
\hline Acido Sulfúrico & Ácido & $\mathrm{H}_{2} \mathrm{SO}_{4}$ & Galvânica, corrosão \\
\hline Antimônio & Metal tóxico & $\mathrm{Sb}$ & Têmpera, ligas \\
\hline Arsênio & Metal tóxico & As & Ligas, soldas \\
\hline Benzeno & BTEX & $\mathrm{C}_{6} \mathrm{H}_{6}$ & Solvente, detergente \\
\hline Bifenilas Policloradas (PCB) & Hidr. Clor. Não Vol & & Fluido isolante \\
\hline Bis-(2-cloroisopropil) - éter & Hidr. Clor. Vol. & $\mathrm{ClCH}_{2} \mathrm{C}\left(\mathrm{CH}_{3} \mathrm{H}\right)_{2} \mathrm{O}$ & Solvente, removedor \\
\hline Cádmio & Metal tóxico & $\mathrm{Cd}$ & Eletrodeposição \\
\hline Chumbo & Metal tóxico & $\mathrm{Pb}$ & Liga, soldas \\
\hline Cloreto de Alila & Organohalogenado & $\mathrm{CH}_{2} \mathrm{CHCH}_{2} \mathrm{CL}$ & Resinas, plásticos \\
\hline Clorobenzeno & Hidr. Clor. Vol. & $\mathrm{C}_{6} \mathrm{H}_{5} \mathrm{Cl}$ & Solvente, fenol \\
\hline Clorofórmio & Solv. Org. Hal. & $\mathrm{CHCl}_{2}$ & Solvente, tingimentos \\
\hline Cloropreno & Solv. Org. Hal. & $\mathrm{H}_{2} \mathrm{C}: \mathrm{CHCCl}: \mathrm{CH}_{2}$ & \\
\hline Cobalto & Metal tóxico & $\mathrm{CO}$ & Galvânica, ligas \\
\hline Cobre & Metal tóxico & $\mathrm{Cu}$ & Galvânica, ligas \\
\hline Corante de Alizarina & Cetona & $\mathrm{C}_{6} \mathrm{H}_{4}\left(\mathrm{CO}_{2}\right) \mathrm{C}_{6} \mathrm{H}_{2}(\mathrm{OH})_{2}$ & Tintas, pigmentos \\
\hline Cromo & Metal tóxico & $\mathrm{Cr} \quad-2$ & Galvânica, ligas \\
\hline Dicloroetano & Solv. Org. Hal. & $\mathrm{ClCH}_{2} \mathrm{CH}_{2} \mathrm{Cl}$ & Solvente, resinas \\
\hline Diclorometano & Solv. Org. Hal. & $\mathrm{CH}_{2} \mathrm{Cl}_{2}$ & Solvente, desengraxante \\
\hline Dicloropropano & Solv. Org. Hal. & $\mathrm{CH}_{3} \mathrm{CHClCH} \mathrm{Cl}_{2}$ & Solvente, desengraxante \\
\hline Epicloridrina & Organohalogenado & $\mathrm{CH}_{2} \mathrm{OCHCH}_{2} \mathrm{Cl}$ & Solventes, resinas \\
\hline Estanho & Metal tóxico & $\mathrm{Sn}$ & Ligas metálicas \\
\hline Etilenocloridrina & Organohalogenado & $\mathrm{ClCH}_{2} \mathrm{CH}_{2} \mathrm{OH}$ & Solvente \\
\hline Hexacloreto de Benzeno & Organohalogenado & $\mathrm{C}_{6} \mathrm{Cl}_{6}$ & Sínteses orgânicas \\
\hline Manganês & Metal tóxico & $\mathrm{Mn}$ & Ferroliga, têmpera \\
\hline Mercúrio & Metal tóxico & $\mathrm{Hg}$ & Amalgamas \\
\hline Molibdênio & Metal tóxico & Mo & Ligas, tintas \\
\hline Niquel & Metal tóxico & $\mathrm{Ni}$ & Ligas, tintas \\
\hline Pentaciorofenol & Organohalogenado & $\mathrm{C}_{6} \mathrm{Cl}_{5} \mathrm{OH}$ & Fungicida, bactericida \\
\hline Percloroetileno & Organohalogenado & $\mathrm{Cl}_{2} \mathrm{C}: \mathrm{CCl}_{2}$ & Solvente, secante \\
\hline Prata & Metal tóxico & $\mathrm{Ag}$ & Galvânica, catalisador \\
\hline Tálio & Metal tóxico & TI & Ligas metálicas \\
\hline Telúrio & Metal tóxico & $\mathrm{Te}$ & $\begin{array}{l}\text { Ligas metálicas } \\
\end{array}$ \\
\hline Tetraclorometano & Organohalogenado & $\mathrm{CCl}_{4}$ & Solvente, desengraxante \\
\hline Tolueno & BTEX & $\mathrm{CH}_{3} \mathrm{C}_{6} \mathrm{H}_{5}$ & Solvente, resinas \\
\hline Tricloroetileno & Organohalogenado & $\mathrm{CHCl:CCl} 2$ & Solvente, desengraxante \\
\hline Urânio & Metal tóxico & Ur & \\
\hline Vanádio & Metal tóxico & $\mathrm{V}$ & Ligas metálicas \\
\hline Xileno & BTEX & $\mathrm{C}_{6} \mathrm{H}_{4}\left(\mathrm{CH}_{3}\right)_{2}$ & Solvente, resinas \\
\hline Zinco & Metal tóxico & $\mathrm{Zn}$ & Galvânica, ligas \\
\hline
\end{tabular}

TABELA 2 - Forjaria e prensa

\section{Substância}

Benzeno

Cianeto de Cálcio

Cromo

Fluoreto

Cianeto de Potássio

Hidroxido de Potássio

Anidrido Maleico

Manganès

Molibdênio

Cianeto de Sódio

Hidroxido de Sódio

Niquel

Bifenilas policloradas (PCB)

Piridina

Ácido Clorídrico

\begin{tabular}{|l|l|}
\hline Gr. Contaminante & Fórmula \\
\hline BTEX & $\mathrm{C}_{6} \mathrm{H}_{6}$ \\
\hline Cianeto & $\mathrm{Ca}(\mathrm{CN})_{2}$ \\
\hline Metal tóxico & $\mathrm{Cr}$ \\
\hline Halogenado & $\mathrm{F}$ \\
\hline Cianeto & $\mathrm{KCN}$ \\
\hline Outros Comp. Org. & $\mathrm{KOH}$ \\
\hline Ácido & $\mathrm{HC}: \mathrm{CHC}(\mathrm{O}) \mathrm{OC}(\mathrm{O})$ \\
\hline Metal tóxico & $\mathrm{Mn}$ \\
\hline Metal tóxico & $\mathrm{Mo}$ \\
\hline Cianeto & $\mathrm{NaCN}$ \\
\hline Outros Comp. Inorg. & $\mathrm{NaOH}$ \\
\hline Metal tóxico & $\mathrm{Ni}$ \\
\hline Hidr. Clor. Não Vol. & \\
\hline Comp. Nitrogenado & $\mathrm{N}(\mathrm{CH})_{4} \mathrm{CH}$ \\
\hline Ácido & $\mathrm{HCl}$ \\
\hline
\end{tabular}

Uso

Solvente

Galvânica, ligas

Galvânica, ligas

Galvânica, ligas

Galvânica, extrator

Galvânica

Preservativo óleos e graxas

Ligas metálicas

Ligas metálicas

Desengraxe (solvente)

Desengraxe (solvente)

Ligas metálicas

Fluído isolante

Solvente

Decapagem 


\begin{tabular}{l|l|l|}
\hline Ácido Sulfúrico & Acido & $\mathrm{H}_{2} \mathrm{SO}_{4}$ \\
\hline Tofueno & BTEX & $\mathrm{CH}_{3} \mathrm{C}_{6} \mathrm{H}_{5}$ \\
\hline Vanádio & Metal tóxico & $\mathrm{V}$ \\
\hline Xileno & BTEX & $\mathrm{C}_{6} \mathrm{H}_{4}\left(\mathrm{CH}_{3}\right)_{2}$ \\
\hline Zinco & Metal tóxico & $\mathrm{Zn}$ \\
\hline
\end{tabular}

Decapagem
Desengraxe (solvente)
Catalizador
Desengraxe (solvente)
Galvânica, ligas

TABELA 3 - Comércio atacadista de combustiveis automotivos

\begin{tabular}{|c|c|c|c|}
\hline Substância & Gr. Contaminante & Fórmula & Uso \\
\hline Acenafteno & PAH & $\mathrm{C}_{10} \mathrm{H}_{6}\left(\mathrm{CH}_{2}\right)_{2}$ & Combustivel, tintas \\
\hline Ácido Sulfúrico & Acido & $\mathrm{H}_{2} \mathrm{SO}_{4}$ & Baterias \\
\hline Arsênio & Metal tóxico & As & Aditivo ligante \\
\hline Benzeno & BTEX & $\mathrm{C}_{6} \mathrm{H}_{6}$ & Desengraxante (solvente) \\
\hline Benzina & Derivado de Petróleo & & Desengraxante (solvente) \\
\hline Benzo (a) pireno & PAH & $\mathrm{C}_{20} \mathrm{H}_{12}$ & Componente oleo diesel \\
\hline Bifenilas Policloradas ( $\mathrm{PCB})$ & Hidr. Clor. Não Vol & & Fluído isolante \\
\hline Boro & Outros Comp. Inorg. & B & Desoxidante (graxas) \\
\hline Carbazol & Comp. Nitrogenado & $\left(\mathrm{C}_{6} \mathrm{H}_{4}\right)_{2} \mathrm{NH}$ & Antioxidante $\mathrm{p} /$ borracha \\
\hline Chumbo & Metal tóxico & $\mathrm{Pb}$ & Baterias \\
\hline Cianeto de Cálcio & Cianeto & $\mathrm{Ca}(\mathrm{CN})_{2}$ & Lixiviante mineral \\
\hline Cianeto de Potássio & Cianeto & $\mathrm{KCN}$ & Extração mineral \\
\hline Cianeto de Sódio & Cianeto & $\mathrm{NaCN}$ & Desengraxante \\
\hline Creosol & Fenol & $\mathrm{CH}_{3} \mathrm{C}_{6} \mathrm{H}_{4} \mathrm{OH}$ & Desoxidante, surfactante \\
\hline Criseno & $\mathrm{PAH}$ & $\mathrm{C}_{18} \mathrm{H}_{12}$ & Combustivel \\
\hline Dibrometano & Solv. Org. Hal. & $\mathrm{CH}_{2} \mathrm{Br}_{2}$ & Solvente \\
\hline Dicloroetano & Solv. Org. Hal. & $\mathrm{ClCH}_{2} \mathrm{CH}_{2} \mathrm{Cl}$ & Desengraxante (solvente) \\
\hline Fenantreno & PAH & $\mathrm{C}_{14} \mathrm{H}_{10}$ & Combustivel \\
\hline Fenol & Fenol & $\mathrm{C}_{6} \mathrm{H}_{5} \mathrm{OH}$ & Solvente lubrificante \\
\hline Fluoranteno & PAH & $\mathrm{C}_{16} \mathrm{H}_{10}$ & Combustivel \\
\hline Fluoreno & PAH & $\mathrm{C}_{6} \mathrm{H}_{4} \mathrm{CH}_{2} \mathrm{C}_{6} \mathrm{H}_{4}$ & Combustivel \\
\hline Hidróxido de Sódio & Outros Comp. Inorg. & $\mathrm{NaOH}$ & Sabão, corrosão \\
\hline Metanol & Alcool & $\mathrm{CH}_{3} \mathrm{OH}$ & Solvente, combustivel \\
\hline Molibdênio & Metal tóxico & Mo & Lubrificantes \\
\hline Nafta & Derivado de Petróleo & & Solvente, thinner \\
\hline Naftaleno & PAH & $\mathrm{C}_{10} \mathrm{H}_{8}$ & Lubrificantes \\
\hline Querosene & Derivado de Petróleo & & Solvente, combustivel \\
\hline Tolueno & BTEX & $\mathrm{CH}_{3} \mathrm{C}_{6} \mathrm{H}_{5}$ & Solvente, combustivel \\
\hline Xileno & BTEX & $\mathrm{C}_{6} \mathrm{H}_{4}\left(\mathrm{CH}_{3}\right)_{2}$ & Solvente, combustivel \\
\hline
\end{tabular}

TABELA 4 - Fabricação de artigos plásticos

\begin{tabular}{|c|c|c|c|}
\hline Substância & Gr. Contaminante & Fórmula & Uso \\
\hline Acido Fórmico & Ácido & $\mathrm{HCOOH}$ & Plastificante \\
\hline Acrilonitrila & Cianeto & $\mathrm{H}_{2} \mathrm{C}: \mathrm{CHCN}$ & Plástico ABS \\
\hline Acroleina & Aldeído & $\mathrm{CH}_{2} \mathrm{CHCHO}$ & Espumas \\
\hline Anidrido Ftálico & Ftalato & $\mathrm{C}_{6} \mathrm{H}_{4}(\mathrm{CO})_{2} \mathrm{O}$ & Plastificante e endurecedor \\
\hline Anilina & Comp. Nitrogenado & $\mathrm{C}_{6} \mathrm{H}_{5} \mathrm{NH}_{2}$ & Antioxidante p/borracha \\
\hline Benzeno & BTEX & $\mathrm{C}_{6} \mathrm{H}_{6}$ & Solvente \\
\hline Benzo (a) pireno & PAH & $\mathrm{C}_{2} \mathrm{OH}_{12}$ & Combustivel \\
\hline Bifenilas policloradas (PCB) & Hidr. Clor. Não Vol. & & Fluído isolante \\
\hline Boro & Outros Comp. inorg. & $\mathrm{B}$ & Desoxidante \\
\hline Cádmio & Metal tóxico & $\mathrm{Cd}$ & Agente plastificante \\
\hline Chumbo & Metal tóxico & $\mathrm{Pb}$ & Solda, chaparia \\
\hline Cianeto de Cálcio & Cianeto & $\mathrm{Ca}(\mathrm{CN})_{2}$ & Precipitador \\
\hline Cianeto de Potássio & Cianeto & $\mathrm{KCN}$ & Extrator de metais \\
\hline Cianeto de Sódio & Cianeto & $\mathrm{NaCN}$ & Tintas e pigmentos \\
\hline Cloropropeno & Solv. Org. Hal. & $\mathrm{H}_{2} \mathrm{C}: \mathrm{CHCCl}: \mathrm{CH}_{2}$ & \\
\hline Cobre & Metal tóxico & $\mathrm{Cu}$ & Ligas metálicas \\
\hline Cromo & Metal tóxico & $\mathrm{Cr}$ & Agente ligante \\
\hline Diclorometano & Solv. Org. Hal. & $\mathrm{CH}_{2} \mathrm{Cl}_{2}$ & Agente plastificante \\
\hline Dicloropropano & Solv. Org. Hal. & $\mathrm{CH}_{3} \mathrm{CHClCH}_{2} \mathrm{Cl}$ & Solvente \\
\hline Disocianato de 4, 4- difenilmetano & Cianeto & $\mathrm{CH}_{2}\left(\mathrm{C}_{6} \mathrm{H}_{4} \mathrm{NCO}\right)_{2}$ & Resina poliuretano \\
\hline Disocianato de Tolueno & Cianeto & $\mathrm{CH}_{3} \mathrm{C}_{6} \mathrm{H}_{3}(\mathrm{NCO})_{2}$ & Espumas de poliuretano \\
\hline Dimetilformamida (DMF) & Comp Nitrogenado & $\mathrm{HCON}\left(\mathrm{CH}_{3}\right)_{2}$ & Solvente p/resinas vinílicas \\
\hline Epicloridrina & Organohalogenado & $\mathrm{CH}_{2} \mathrm{OCHCH}_{2} \mathrm{Cl}$ & Resinas epoxi e fenólicas \\
\hline
\end{tabular}




\begin{tabular}{l} 
Estanho \\
Estireno \\
\hline Fenol \\
\hline Hidroxido de Sódio \\
Manganês \\
\hline Nitrotoluol \\
\hline Selênio \\
\hline Titânio \\
\hline Tricloroetano \\
\hline Zinco \\
\hline
\end{tabular}

\begin{tabular}{|l}
\hline Metal tóxico \\
\hline BTEX \\
Fenol \\
\hline Outros Comp. Inorg. \\
\hline Metal tóxico \\
\hline Comp. Nitrogenado \\
\hline Metal tóxico \\
\hline Metal tóxico \\
\hline Solv. Org. Hal. \\
\hline Metal tóxico \\
\hline
\end{tabular}

\begin{tabular}{|l|}
\hline $\mathrm{Sn}$ \\
\hline$\left(\mathrm{C}_{6} \mathrm{H}_{5} \mathrm{CH}: \mathrm{CH}_{2}\right) \mathrm{n}$ \\
\hline $\mathrm{C}_{6} \mathrm{H}_{5} \mathrm{OH}$ \\
\hline $\mathrm{NaOH}$ \\
\hline $\mathrm{Mn}$ \\
\hline $\mathrm{NO}_{2} \mathrm{C}_{6} \mathrm{H}_{4} \mathrm{CH}_{3}$ \\
\hline $\mathrm{Se}$ \\
\hline $\mathrm{Ti}$ \\
\hline $\mathrm{CHCl}: \mathrm{CCl}_{2}$ \\
\hline $\mathrm{Zn}$ \\
\hline
\end{tabular}

Ligas metálicas Plástico ABS, SBR, SAN

Tintas e resinas

Limpeza

Ligas metálicas

Tintas sintéticas

Catalizador e acelerador

Ligas metálicas

Metal tóxico

Limpeza de metais

TABELA 5 - Laminação de metais e aços especiais

\begin{tabular}{|c|c|c|c|}
\hline Substância & Gr. Contaminante & Fórmula & Uso \\
\hline Acenafteno & PAH & $\mathrm{C}_{10} \mathrm{H}_{6}\left(\mathrm{CH}_{2}\right)_{2}$ & Tintas e corantes \\
\hline Ácido Fluoridrico & Acido & $\mathrm{HF}$ & Decapagem \\
\hline Ácido Nítrico & Ácido & $\mathrm{HNO}_{3}$ & Decapagem \\
\hline Antraceno & PAH & $\mathrm{C}_{6} \mathrm{H}_{4}(\mathrm{CH})_{2} \mathrm{C}_{6} \mathrm{H}_{4}$ & Combustivel \\
\hline Arsênio & Metal tóxico & As & Aditivo ligante para metais \\
\hline Bário & Metal tóxico & $\mathrm{Ba}$ & Desoxidante, têmpera \\
\hline Benzo (a) pireno & $\mathrm{PAH}$ & $\mathrm{C}_{20} \mathrm{H}_{12}$ & Combustivel \\
\hline Berílio & Metal tóxico & $\mathrm{Be}$ & Aditivo ligante para metais \\
\hline Bifenílas policloradas (PCB) & Hidr. Clor. Não Vol. & & Fluido isolante \\
\hline Boro & Outros Comp. Inorg. & $\mathrm{B}$ & Cementação de ferro \\
\hline Cádmio & Metal tóxico & $\mathrm{Cd}$ & Eletrodeposicão metais \\
\hline Carbazol & Comp. Nitrogenado & $\left(\mathrm{C}_{6} \mathrm{H}_{4}\right)_{2} \mathrm{NH}$ & Reagente \\
\hline Chumbo & Metal tóxico & $\mathrm{Pb}$ & Aditivo ligante para metais \\
\hline Cianeto de Cálcio & Cianeto & $\mathrm{Ca}(\mathrm{CN})_{2}$ & Lixiviante de metais \\
\hline Cianeto de Potássio & Cianeto & $\mathrm{KCN}$ & Extrator de metais \\
\hline Cianeto de Sódio & Cianeto & $\mathrm{NaCN}$ & Flotação \\
\hline Cobalto & Metal tóxico & Co & Cementacão de ferro \\
\hline Criseno & $\mathrm{PAH}$ & $\mathrm{C}_{18} \mathrm{H}_{12}$ & Sintese orgânica \\
\hline Cromo & Metal tóxico & $\mathrm{Cr}$ & Aditivo ligante para metais \\
\hline Enxofre & Comp. Sulfurado & $S$ & Decapagem \\
\hline Estanho & Metal tóxico & Sn & Ligas metálicas \\
\hline Fenantreno & $\mathrm{PAH}$ & $\mathrm{C}_{14} \mathrm{H}_{10}$ & Combustivel \\
\hline Fenol & Fenol & $\mathrm{C}_{6} \mathrm{H}_{5} \mathrm{OH}$ & Solvente \\
\hline Fluoranteno & $\mathrm{PAH}$ & $\mathrm{C}_{16} \mathrm{H}_{10}$ & Combustivel \\
\hline Fluoreno & $\mathrm{PAH}$ & $\mathrm{C}_{6} \mathrm{H}_{4} \mathrm{CH}_{2} \mathrm{C}_{6} \mathrm{H}_{4}$ & Combustivel \\
\hline Hidroxido de Potássio & Outros Comp.Org. & $\mathrm{KOH}$ & Aditivo ligante para metais \\
\hline Hidroxido de Sódio & Outros Comp. Inorg. & $\mathrm{NaOH}$ & Decapagem \\
\hline Manganês & Metal tóxico & $\mathrm{Mn}$ & Ligas metálicas \\
\hline Naftaleno & PAH & $\mathrm{C}_{10} \mathrm{H}_{8}$ & Lubrificante \\
\hline Niquel & Metal tóxico & $\mathrm{Ni}$ & Ligas metálicas \\
\hline Telúrio & Metal tóxico & $\mathrm{Te}$ & Ligas metálicas \\
\hline Titânio & Metal tóxico & $\mathrm{Ti}$ & Ligas metálicas \\
\hline Vanádio & Metal tóxico & $\mathrm{V}$ & Ligas metálicas \\
\hline Xileno & BTEX & $\mathrm{C}_{6} \mathrm{H}_{4}\left(\mathrm{CH}_{3}\right)_{2}$ & Solvente \\
\hline Zinco & Metal tóxico & $\mathrm{Zn}$ & Ligas metálicas \\
\hline
\end{tabular}

\section{TABELA 6 - Fabricação de desoxidantes e anti-corrosivos}

\begin{tabular}{|c|c|c|c|}
\hline Substância & Gr. Contaminante & Fórmula & Uso \\
\hline Ácido Fosfórico & Ácido & $\mathrm{H}_{3} \mathrm{PO}_{4}$ & Detergente, sabão \\
\hline Amoníaco & Comp. Nitrogenado & $\mathrm{NH}_{3}$ & Condensação de polimeros \\
\hline Benzeno & BTEX & $\mathrm{C}_{6} \mathrm{H}_{6}$ & Solvente, detergentes \\
\hline Bifenilas Policloradas (PCB) & Hidr. Clor. Não Vol. & & Fluido isolante \\
\hline Bis - (2-cloroisoprpil) - éter & Solv. Org. Hal. & $\mathrm{ClCH}_{2} \mathrm{C}\left(\mathrm{CH}_{3} \mathrm{H}\right)_{2} \mathrm{O}$ & Solvente, removedores \\
\hline Chumbo & Metal tóxico & $\mathrm{Pb}$ & Aditivo \\
\hline Cloreto de Alila & Organohalogendo & $\mathrm{CH}_{2} \mathrm{CHCH}_{2} \mathrm{Cl}$ & Resinas \\
\hline Clorobenzeno & Solv. Org. Hal. & $\mathrm{C}_{6} \mathrm{H}_{5} \mathrm{Cl}$ & Solvente, fenol \\
\hline Clorofórmio & Solv Org. Hal. & $\mathrm{CHCl}_{2}$ & Solvente \\
\hline Cloropreno & Solv. Org. Hal. & $\mathrm{H}_{2} \mathrm{C}: \mathrm{CHCCl}: \mathrm{CH}_{2}$ & \\
\hline DibenzoDioxinas Policlorada & Dioxinas & & \\
\hline Dicloroetano & Solv. Org. Hal. & $\mathrm{ClCH}_{2} \mathrm{CH}_{2} \mathrm{Cl}$ & Solvente p/éter \\
\hline
\end{tabular}




\begin{tabular}{l|l|l|}
\hline Diclorometano & Solv. Org. Hal. & $\mathrm{CH}_{2} \mathrm{Cl}_{2}$ \\
\hline Dicloropropano & Solv. Org. Hal. & $\mathrm{CH}_{3} \mathrm{CHClCH}_{2} \mathrm{Cl}$ \\
\hline Epicloridrina & Solv. Org. Hal. & $\mathrm{CH}_{2} \mathrm{OCHCHCH}_{2} \mathrm{Cl}$ \\
\hline Etilenocloridrina & Solv. Org. Hal. & $\mathrm{ClCH}_{2} \mathrm{CH}_{2} \mathrm{OH}$ \\
\hline Hexacloreto de Benzeno & Solv. Org. Hal. & $\mathrm{C}_{6} \mathrm{Cl}_{6}$ \\
\hline Hidroxido de Potássio & Outros Comp Org. & $\mathrm{KOH}$ \\
\hline Hidroxido de Sódio & Outros Comp inorg. & $\mathrm{NaOH}$ \\
\hline Nitrato de Sódio & Comp. Nitrogenado & $\mathrm{NaNO}_{3}$ \\
\hline Pentaclorofenol & Hidr. Clor. Vol. & $\mathrm{C}_{6} \mathrm{Cl}_{5} \mathrm{OH}$ \\
\hline Tetracloroetileno & Solv. Org. Hal. & $\mathrm{Cl}_{2} \mathrm{C}: \mathrm{CCl}_{2}$ \\
\hline Tetraclorometano & Solv. Org. Hal. & $\mathrm{CCl}_{4}$ \\
\hline Tolueno & BTEX & $\mathrm{CH}_{3} \mathrm{CH}_{6} \mathrm{H}_{5}$ \\
\hline Tricloroetano & Solv. Org. Hal. & $\mathrm{CHCl}_{2} \mathrm{CH}_{2} \mathrm{Cl}$ \\
\hline Tricloroetileno & Solv. Org. Hal. & $\mathrm{CHCCl:CCl}_{2}$ \\
\hline Xileno & BTEX & $\mathrm{C}_{6} \mathrm{H}_{4}\left(\mathrm{CH}_{3}\right)_{2}$ \\
\hline
\end{tabular}

Solvente, desengraxante Solvente, desengraxante Solvente $\mathrm{p} /$ éster Solvente Sinteses orgânicas Manufatura de sabão Agente oxidante Agente oxidante Bactericida, algicida Solvente, secante p/metais Solvente, desengraxante Solvente Solvente, desengraxante Desengraxante, extrator Solvente

TABELA 7 - Tornearia

\begin{tabular}{|c|c|c|c|}
\hline Substâncias & Gr. Contaminante & Fórmula & Uso \\
\hline Ácido Cloridrico & Ácido & $\mathrm{HCl}$ & Limpeza de metais \\
\hline Ácido Sulfúrico & Ácido & $\mathrm{H}_{2} \mathrm{SO}_{4}$ & Galvânica, metalurgia \\
\hline Antimônio & Metal tóxico & $\mathrm{Sb}$ & Liga, solda \\
\hline Arsênio & Metal tóxico & As & Liga, solda \\
\hline Benzeno & BTEX & $\mathrm{C}_{6} \mathrm{H}_{6}$ & Solvente, detergente \\
\hline Bifenilas Policloradas (PCB) & Hidr. Clor. Não Vol. & & Fluido isolante \\
\hline Bis-(2-cloroisopropil) - éter & Solv. Org. Hal. & $\mathrm{ClCH}_{2} \mathrm{C}\left(\mathrm{CH}_{3} \mathrm{H}_{2} \mathrm{O}\right.$ & Solvente, thinner \\
\hline Cádmio & Metal tóxico & $\mathrm{Cd}$ & Eletrodeposição de tintas \\
\hline Chumbo & Metal tóxico & $\mathrm{Pb}$ & Liga, solda \\
\hline Cloreto de Alila & Organohalogenado & $\mathrm{CH}_{2} \mathrm{CHCH}_{2} \mathrm{Cl}$ & Resinas, plásticos \\
\hline Clorobenzeno & Hidr. Clor. Vol. & $\mathrm{C}_{6} \mathrm{H}_{5} \mathrm{Cl}$ & Solvente, fenol \\
\hline Clorofórmio & Comp Org. Hal. Vol. & $\mathrm{CHCl}_{2}$ & Solvente \\
\hline Cloropreno & Solv. Org Hal. & $\mathrm{H}_{2} \mathrm{C}: \mathrm{CHCCl} \mathrm{CH}_{2}$ & Borrachas \\
\hline Cobalto & Metal tóxico & Co & Galvânica, cementação \\
\hline Cromo & Metal tóxico & $\mathrm{Cr}$ & Liga, aço-inox, plástico \\
\hline DibenzoDioxinas Policlorada & Dioxinas & & \\
\hline Dicloroetano & Solv. Org. Hal. & $\mathrm{ClCH}_{2} \mathrm{CH}_{2} \mathrm{Cl}$ & Solvente, resinas \\
\hline Diclorometano & Solv. Org. Hal. & $\mathrm{CH}_{2} \mathrm{Cl}_{2}$ & Solvente, desengraxante \\
\hline Dicloropropano & Solv. Org. Hal. & $\mathrm{CH}_{3} \mathrm{CHClCH}{ }_{2} \mathrm{Cl}$ & Solvente, desengraxante \\
\hline Epicloridrina & Solv. Org. Hal. & $\mathrm{CH}_{2} \mathrm{OCHCH} \mathrm{Cl}_{2}$ & Solvente, resinas \\
\hline Estanho & Metal tóxico & $\mathrm{Sn}$ & Ligas metálicas \\
\hline Etilenocloridrina & Solv. Org. Hal. & $\mathrm{ClCH}_{2} \mathrm{CH}_{2} \mathrm{OH}$ & Solvente \\
\hline Formaldeido & Aldeido & $\mathrm{HCHO}$ & Inibidor de corrosão \\
\hline Hexacloreto de Benzeno & Solv. Org. Hal. & $\mathrm{C}_{6} \mathrm{Cl}_{6}$ & Sinteses orgânicas \\
\hline Hidróxido de Sódio & Outros Comp. Org. & $\mathrm{NaOH}$ & Sabão, Galvânica \\
\hline Manganês & Metal tóxico & $\mathrm{Mn}$ & Ferroligas \\
\hline Mercúrio & Metal tóxico & $\mathrm{Hg}$ & Amalgamas \\
\hline Molibdênio & Metal tóxico & Mo & Ligas metálicas \\
\hline Niquel & Metal tóxico & $\mathrm{Ni}$ & Ligas, magnetos \\
\hline Pentaclorofenol & Solv. Org. Hal. & $\mathrm{C}_{6} \mathrm{Cl}_{5} \mathrm{OH}$ & Fungicida, algicida \\
\hline Percloroetileno & Solv. Org. Hal. & $\mathrm{Cl}_{2} \mathrm{C}: \mathrm{CCl}_{2}$ & Solvente, secante metais \\
\hline Prata & Metal tóxico & $\mathrm{Ag}$ & Galvânica, têmpera \\
\hline Tálio & Metal tóxico & $\mathrm{TI}$ & Ligas metálicas \\
\hline Telúrio & Metal tóxico & $\mathrm{Te}$ & Ligas metálicas \\
\hline Tetraclorometano & Solv. Org. Hal. & $\mathrm{CCl}_{4}$ & Solvente, desengraxante \\
\hline Tolueno & BTEX & $\mathrm{CH}_{3} \mathrm{C}_{6} \mathrm{H}_{5}$ & Solvente, ligas, resinas \\
\hline Tricloroetano & Solv Org. Hal. & $\mathrm{CHCl}_{2} \mathrm{CH}_{2} \mathrm{Cl}$ & Solvente, desengraxante \\
\hline Tricloroetileno & Solv. Org. Hal. & $\mathrm{CHCl}: \mathrm{CCl}_{2}$ & Desengraxante, secante \\
\hline Urânio & Metal tóxico & Ur & \\
\hline Vanádio & Metal tóxico & $\mathrm{V}$ & Ligas metálicas \\
\hline Xileno & BTEX & $\mathrm{C}_{6} \mathrm{H}_{4}\left(\mathrm{CH}_{3}\right)_{2}$ & Solvente, esmaltes \\
\hline Zinco & Metal tóxico & $\mathrm{Zn}$ & Galvânica, ligas \\
\hline
\end{tabular}




\begin{tabular}{|c|c|c|c|}
\hline Substância & Gr. Contaminante & Fórmula & Uso \\
\hline Acido Nitrico & Ácido & $\mathrm{HNO}_{3}$ & Explosivo \\
\hline Ácido Sulfúrico & Ácido & $\mathrm{H}_{2} \mathrm{SO}_{4}$ & Explosivo \\
\hline Amônia & Comp. Nitrogenado & $\mathrm{NH}_{4}$ & Ácido nítrico \\
\hline Anidrido Acético & Anidrido & $\left(\mathrm{CH}_{3} \mathrm{CO}\right)_{2} \mathrm{O}$ & Explosivo \\
\hline Anilina & Comp. Nitrogenado & $\mathrm{C}_{6} \mathrm{H}_{5} \mathrm{NH}_{2}$ & Antioxidante \\
\hline Arsênio & Metal tóxico & As & Aditivo ligante \\
\hline Carbazol & Comp. Nitrogenado & $\left(\mathrm{C}_{6} \mathrm{H}_{4}\right)_{2} \mathrm{NH}$ & Explosivo \\
\hline Chumbo & Metal tóxico & $\mathrm{Pb}$ & Ligas metálicas \\
\hline Cianeto de Potássio & Cianeto & $\mathrm{KCN}$ & Extrator mineral \\
\hline Clorobenzeno & Solv. Org. Hal. & $\mathrm{C}_{6} \mathrm{H}_{6} \mathrm{Cl}$ & Anilina, solvente \\
\hline Cloronaftaleno & PAH & $\mathrm{C}_{10} \mathrm{H}_{7} \mathrm{Cl}$ & Aditivo ligante \\
\hline Cobre & Metal tóxico & $\mathrm{Cu}$ & Ligas metálicas \\
\hline Cromo & Metal tóxico & $\mathrm{Cr}$ & Aditivo ligante \\
\hline Dinitrofenol & Fenol & $\mathrm{C}_{6} \mathrm{H}_{3} \mathrm{OH}\left(\mathrm{NO}_{2}\right)_{2}$ & Explosivo \\
\hline Formaldeido & Aldeido & $\mathrm{HCHO}$ & Resinas fenólicas \\
\hline Naftaleno & $\mathrm{PAH}$ & $\mathrm{C}_{10} \mathrm{H}_{8}$ & Intermediário \\
\hline Nitrobenzeno & Comp. Nitrogenado & $\mathrm{C}_{6} \mathrm{H}_{5} \mathrm{NO}_{2}$ & Solvente \\
\hline Nitrocelulose & Comp. Nitrogenado & $\mathrm{C}_{6} \mathrm{H}_{7} \mathrm{O}_{2}\left(\mathrm{ONO}_{2}\right)_{3}$ & Explosivo \\
\hline Nitrotoluol & Comp. Nitrogenado & $\mathrm{NO}_{2} \mathrm{C}_{6} \mathrm{H}_{4} \mathrm{CH}_{3}$ & Sinteses orgânicas \\
\hline Trinitrotolueno & Comp. Nitrogenado & $\mathrm{CH}_{3} \mathrm{C}_{6} \mathrm{H}_{2}\left(\mathrm{NO}_{2}\right)_{3}$ & Explosivo \\
\hline
\end{tabular}

TABELA 9 - Indústria de placas de circuito impresso

\begin{tabular}{|c|c|c|c|}
\hline Substância & Gr. Contaminante & Fórmula & Uso \\
\hline Ácido Cloridrico & Acido & $\mathrm{HCl}$ & Limpeza de metais \\
\hline Ácido Crômico & Ácido & $\mathrm{CrO}_{3}$ & Capeamento, anodização \\
\hline Acido Fluoridrico & Acido & $\mathrm{HF}$ & Limpeza de metais \\
\hline Ácido fosfórico & Acido & $\mathrm{H}_{3} \mathrm{PO}_{4}$ & Eletropolimento, detergente \\
\hline Ácido Sulfúrico & Acido & $\mathrm{H}_{2} \mathrm{SO}_{4}$ & Galvânica, metalurgia \\
\hline Antimônio & Metal tóxico & $\mathrm{Sb}$ & Solda, semicondutores \\
\hline Arsênio & Metal tóxico & As & Solda, semicondutores \\
\hline Benzeno & BTEX & $\mathrm{C}_{6} \mathrm{H}_{6}$ & Solvente \\
\hline Bifenilas policloradas (PCB) & Organohalogenado & & Fluído isolante \\
\hline Bis - $(2$ - cloroisopropil $)$ - éter & Solv. Org. Hal.. & $\mathrm{ClCH}_{2} \mathrm{C}\left(\mathrm{CH}_{3} \mathrm{H}\right)_{2} \mathrm{O}$ & Solvente, desengraxante \\
\hline Cádmio & Metal tóxico & $\mathrm{Cd}$ & Baterias, eletrodeposição \\
\hline Chumbo & Metal tóxico & $\mathrm{Pb}$ & Solda, baterias \\
\hline Cianetos & Cianeto & & Galvânica, metalurgia \\
\hline Cloreto de Alila & Organohalogenado & $\mathrm{CH}_{2} \mathrm{CHCH}_{2} \mathrm{Cl}$ & Resinas, plásticos, adesivos \\
\hline Clorobenzeno & Hidr Clor. Vol. & $\mathrm{C}_{6} \mathrm{H}_{5} \mathrm{Cl}$ & Solvente \\
\hline Clorofórmio & Solv. Org. Hal. & $\mathrm{CHCl}_{2}$ & Solvente \\
\hline Cloropreno & Organohalogenado & $\mathrm{H}_{2} \mathrm{C}: \mathrm{CHCCl}: \mathrm{CH}_{2}$ & \\
\hline Cobalto & Metal tóxico & Co & Galvânica, oxidante \\
\hline Cobre & Metal tóxico & $\mathrm{Cu}$ & Galvânica, condutores \\
\hline Cromo & Metal tóxico & $\mathrm{Cr}$ & Ligante p/metais e plástico \\
\hline Dicloroetano & Solv. Org. Hal. & $\mathrm{ClCH}_{2} \mathrm{CH}_{2} \mathrm{Cl}$ & Solvente $\mathrm{p} /$ resinas \\
\hline Diclorometano & Solv. Org. Hal. & $\mathrm{CH}_{2} \mathrm{Cl}_{2}$ & Solvente, desengraxante \\
\hline Dicloropropano & Solv. Org. Hal. & $\mathrm{CH}_{3} \mathrm{CHClCH}{ }_{2} \mathrm{Cl}$ & Solvente, desengraxante \\
\hline Epicloridrina & Hidr. Clor. Não Vol. & $\mathrm{CH}_{2} \mathrm{OCHCH} 2 \mathrm{Cl}$ & Resinas epoxi e fenólicas \\
\hline Estanho & Metal tóxico & Sn & Ligas metálicas \\
\hline Etilenocloridrina & Solv. Org. Hal. & $\mathrm{ClCH}_{2} \mathrm{CH}_{2} \mathrm{OH}$ & Solvente \\
\hline Hexacloreto de Benzeno & Solv. Org. Hal. & $\mathrm{C}_{6} \mathrm{Cl}_{6}$ & Sinteses orgânicas \\
\hline Hidroxido de Potássio & Outros Comp Org. & $\mathrm{KOH}$ & Galvânica, sabão \\
\hline Hidroxido de Sódio & Outros Comp. Inorg. & $\mathrm{NaOH}$ & Eletrogalvanização, sabão \\
\hline Manganês & Metal tóxico & $\mathrm{Mn}$ & Ligas não ferrosas \\
\hline Mercúrio & Metal tóxico & $\mathrm{Hg}$ & Ligas, instrumentação \\
\hline Molibdênio & Metal tóxico & Mo & Ligas p/altas temperaturas \\
\hline Níquel & Metal tóxico & $\mathrm{Ni}$ & Ligas, magnetos, baterias \\
\hline Pentaclorofenol & Solv. Org. Hal. & $\mathrm{C}_{6} \mathrm{Cl}_{5} \mathrm{OH}$ & Bactericida \\
\hline Percloroetileno & Solv. Org. Hal. & $\mathrm{Cl}_{2} \mathrm{C}: \mathrm{CCl}_{2}$ & Solvente, secante $p /$ metais \\
\hline Piridina & Comp. Nitrogenado & $\mathrm{N}(\mathrm{CH})_{4} \mathrm{CH}$ & Solvente \\
\hline Prata & Metal tóxico & $\mathrm{Ag}$ & Galvânica, contatos \\
\hline Tálio & Metal tóxico & $\pi$ & Aplicações fotoelétricas \\
\hline
\end{tabular}




\begin{tabular}{l|l|l|}
\hline Telúrio & Metal tóxico & $\mathrm{Te}$ \\
\hline Tetraclorometano & Solv. Org. Hal & $\mathrm{CCl}_{4}$ \\
\hline Tolueno & $\mathrm{BTEX}$ & $\mathrm{CH}_{3} \mathrm{C}_{6} \mathrm{H}_{5}$ \\
\hline Tricloroetano & Solv. Org. Hal & $\mathrm{CHCCl}_{2} \mathrm{CH}_{2} \mathrm{Cl}$ \\
\hline Tricloroetileno & Solv. Org. Hal. & $\mathrm{CHCl}_{\mathrm{CHCl}} \mathrm{CCl}_{2}$ \\
\hline Urânio & Metal tóxico & $\mathrm{Ur}$ \\
\hline Vanádio & Metal tóxico & $\mathrm{V}$ \\
\hline Xileno & BTEX & $\mathrm{C}_{6} \mathrm{H}_{4}\left(\mathrm{CH}_{3}\right)_{2}$ \\
\hline Zinco & Metal tóxico & $\mathrm{Zn}$ \\
\hline
\end{tabular}

Ligas, baterias

Semicondutores, solvente

Solvente, colas

Desengraxante, resinas

Secante p/equip. eletrônico

Ligas metálicas

Solvente, resinas

Baterias, eletrodeposição

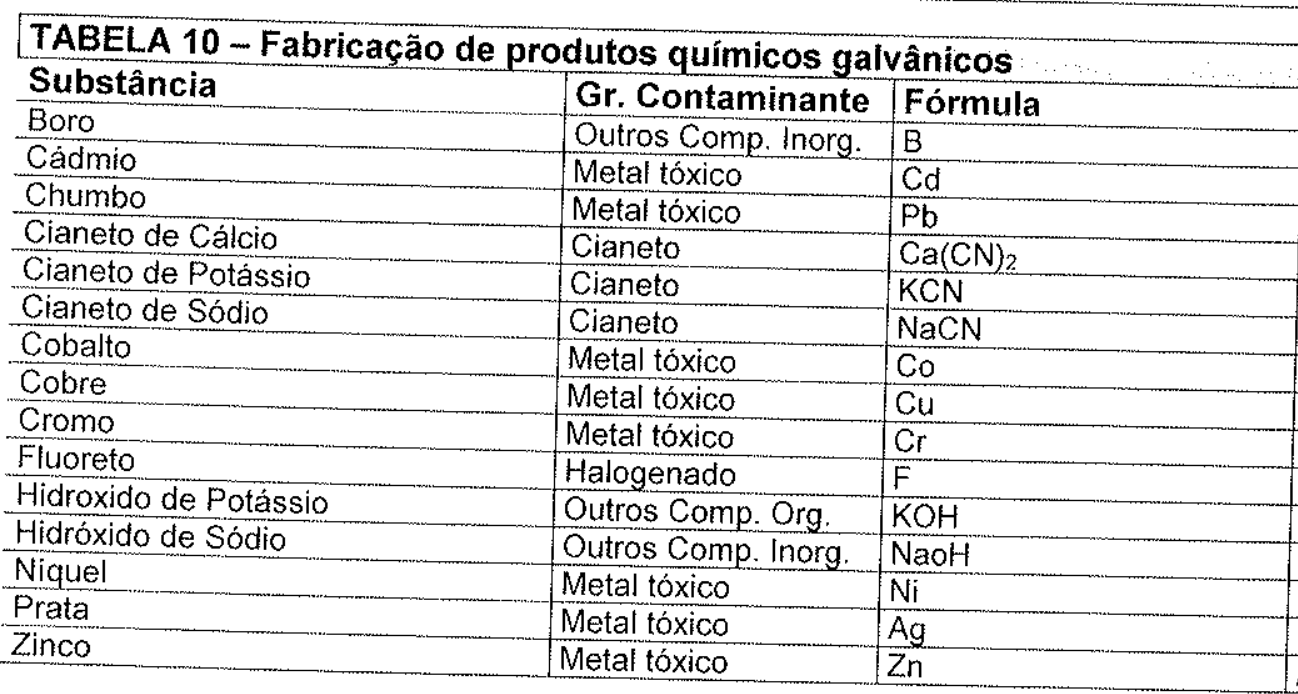

TABELA 11 - Fabricação de tintas e vernizes

\section{Substância}

Ácido Benzosulfônico

Acido Clorídrico

Ácido nítrico

Ácido Oxálico

Amônia

Anidrido Acético

Anidrido Ftálico

Anidrido Maleico

Antimônio

Arsênio

Asbesto

Benzeno

Benzidina

Benzina

Berílio

Bifenilas policloradas (PCB)

Bisulfeto de Carbono

Cádmio

Chumbo

Cianeto de Sódio

Ciclohexanona

Cloreto de Alila

Cloronitrobenzeno

Cobalto

Cobre

Cresol

Cromo

Diclorometano

Diisocianato de Tolueno

Dimetilformamida (DMF)

Dinitrofenol

Enxofre

Epicloridrina

\section{Gr. Contaminante}

Ácido

Ácido

Ácido

Ácido

Comp. Nitrogenado

Anidrido

Ftalato

Ácido

Metal tóxico

Metal tóxico

Outros Comp. Inorg.

BTEX

Comp. Nitrogenado

Derivado de Petróleo

Metal tóxico

Hidr. Clor. Não Vol

Comp. Sulfurado

Metal tóxico

Metal tóxico

Cianeto

Cetona

Solv. Org. Hal.

Hidr. Clor. Não Vol.

Metal tóxico

Metal tóxico

Fenol

Metal tóxico

Solv. Org. Hal.

Cianeto

Comp. Nitrogenado

Fenol

Comp. Sulfurado

Solv. Org. Hal

\begin{tabular}{|l|}
\hline Fórmula \\
\hline $\mathrm{C}_{6} \mathrm{H}_{5} \mathrm{SO}_{3} \mathrm{H}$ \\
\hline $\mathrm{HCl}$ \\
\hline $\mathrm{HNO}_{3}$ \\
\hline $\mathrm{HOOCCOOH}{ }_{2} \mathrm{H}_{2} \mathrm{O}$ \\
\hline $\mathrm{NH}_{4}$ \\
\hline$\left(\mathrm{CH}_{3} \mathrm{CO}\right)_{2} \mathrm{O}$ \\
\hline $\mathrm{C}_{6} \mathrm{H}_{4}(\mathrm{CO})_{2} \mathrm{O}$ \\
\hline $\mathrm{HC}: \mathrm{CHC}(\mathrm{O}) \mathrm{OC}(\mathrm{O})$ \\
\hline $\mathrm{Sb}$ \\
\hline $\mathrm{As}$
\end{tabular}

$\mathrm{C}_{6} \mathrm{H}_{6}$

$\mathrm{NH}_{2}\left(\mathrm{C}_{6} \mathrm{H}_{4}\right)_{2} \mathrm{NH}_{2}$

$\mathrm{Be}$

CS2

Cd

$\mathrm{Pb}$

$\mathrm{NaCN}$

$\mathrm{C}_{6} \mathrm{H}_{10} \mathrm{O}$

$\mathrm{CH}_{2} \mathrm{CHCH}_{2} \mathrm{Cl}$

$\mathrm{C}_{6} \mathrm{H}_{4} \mathrm{CINO}_{2}$

$\mathrm{CO}$

$\mathrm{CH}_{3} \mathrm{C}_{6} \mathrm{H}_{4} \mathrm{OH}$

$\mathrm{Cr}$

$\mathrm{CH}_{2} \mathrm{Cl}_{2}$

$\mathrm{CH}_{3} \mathrm{C}_{6} \mathrm{H}_{3}(\mathrm{NCO}$

$\mathrm{HCON}\left(\mathrm{CH}_{3}\right)_{2}$

$\mathrm{C}_{6} \mathrm{H}_{3} \mathrm{OH}\left(\mathrm{NO}_{2}\right)_{2}$

$\mathrm{S}$

$\mathrm{CH}_{2} \mathrm{OCHCH}_{2} \mathrm{Cl}$
Uso

Desoxidante, desgaseificante

Agente eletroativo

Ligas metálicas

Lixiviante para metais

Extrator para metais

Desengraxante

Oxidante

Ligante, condutor

Ligante $p /$ metais e plástico

Oxidante

Desengraxante

Eletroativo, solvente

Prop. Eletromagnéticas

Prop. Catalíticas

Agente eletroativo
Uso

Matéria prima

Redutor de minerais

Pigmento

Limpeza de metais

Tintas

Matéria prima $\mathrm{p} /$ tinta

Plastificante, endurecedor

Aditivo protetivo

Aditivo ligante

Aditivo ligante

Carga em tintas

Solvente

Corantes

Solvente

Aditivo ligante

Fluído isolante

Solvente

Agente eletroativo

Aditivo ligante

Removedor de tinta e verniz

Tintas e pigmentos

Matéria prima $\mathrm{p} / \mathrm{tinta}$

Aditivo ligante

Tintas protetivas

Surfactante

Aditivo ligante

Removedor de tinta e verniz

Elastômero

Sintese orgânica

Pigmento

Selante

Solvente 


\begin{tabular}{|c|c|c|c|}
\hline Estanho & Metal tóxico & Sn & Ligas metálicas \\
\hline Estireno & BTEX & $\left(\mathrm{C}_{6} \mathrm{H}_{5} \mathrm{CH}: \mathrm{CH}_{2}\right) n$ & Tinta \\
\hline Etilenocloridrina & Solv. Org. Hal. & $\mathrm{ClCH}_{2} \mathrm{CH}_{2} \mathrm{OH}$ & Solvente \\
\hline Etilenoglicol & Álcool & $\mathrm{CH}_{2} \mathrm{OHCH}_{2} \mathrm{OH}$ & Matéria prima $p /$ vernizes \\
\hline Fenantreno & PAH & $\mathrm{C}_{14} \mathrm{H}_{10}$ & Pigmento \\
\hline Fenol & Fenol & $\mathrm{C}_{6} \mathrm{H}_{5} \mathrm{OH}$ & Matéria prima $p /$ tinta \\
\hline Fluoreno & PAH & $\mathrm{C}_{6} \mathrm{H}_{4} \mathrm{CH}_{2} \mathrm{C}_{6} \mathrm{H}_{4}$ & Aditivo ligante \\
\hline Fosfato & Comp. Fosforado & & Agente detergente \\
\hline Hidroxido de Sódio & Outros Comp. Inorg. & $\mathrm{NaOH}$ & Agente $p$ / eletroativaçäo \\
\hline Manganês & Metal tóxico & $\mathrm{Mn}$ & Aditivo ligante \\
\hline Mercúrio & Metal tóxico & $\mathrm{Hg}$ & Amalgamas \\
\hline Metanol & Álcool & $\mathrm{CH}_{3} \mathrm{OH}$ & Solvente \\
\hline Molibdênio & Metal tóxico & Mo & Pigmento \\
\hline Naftaleno & $\mathrm{PAH}$ & $\mathrm{C}_{10} \mathrm{H}_{8}$ & Emulsificante \\
\hline Níquel & Metal tóxico & $\mathrm{Ni}$ & Tintas eletro-protetivas \\
\hline Nitrato de Sódio & Comp. Nitrogenado & $\mathrm{NaNO}_{3}$ & Agente antioxidante \\
\hline Nitrocelulose & Comp. Nitrogenado & $\left.\mathrm{C}_{6} \mathrm{H}_{7}\right)_{2}\left(\mathrm{ONO}_{2}\right)_{3}$ & Vernizes automotivos \\
\hline Nitrotoluol & Comp. Nitrogenado & $\mathrm{NO}_{2} \mathrm{C}_{6} \mathrm{H}_{4} \mathrm{CH}_{3}$ & Tintas sintéticas \\
\hline$P$ - quinona & Cetona & $\mathrm{C}_{6} \mathrm{H}_{4} \mathrm{O}_{2}$ & Tintas \\
\hline Pentaclorofenol & Hidr. Clor. Não Vol. & $\mathrm{C}_{6} \mathrm{Cl}_{5} \mathrm{OH}$ & Preservativo, algicida \\
\hline Percloroetileno & Solv. Org. Hal. & $\mathrm{Cl}_{2} \mathrm{C}: \mathrm{CCl}_{2}$ & Solvente \\
\hline Piridina & Comp. Nitrogenado & $\mathrm{N}(\mathrm{CH})_{4} \mathrm{CH}$ & Pigmento \\
\hline Prata & Metal tóxico & $\mathrm{Ag}$ & Pigmento \\
\hline Tálio & Metal tóxico & $\mathrm{TI}$ & Ligas metálicas \\
\hline Tetraclorometano & Solv. Org. Hal. & $\mathrm{CCl} 4$ & Solvente \\
\hline Titânio & Metal tóxico & $\mathrm{Ti}$ & Ligas metálicas \\
\hline Tolueno & BTEX & $\mathrm{CH}_{3} \mathrm{C}_{6} \mathrm{H}_{5}$ & Vernizes, solventes \\
\hline Tricloroetano & Solv. Org. Hal. & $\mathrm{CHCl}_{2} \mathrm{CH}_{2} \mathrm{Cl}$ & $\begin{array}{l}\text { Solvente } \\
\end{array}$ \\
\hline Tricloroetileno & Solv. Org. Hal. & $\mathrm{CHCl}: \mathrm{CC}_{2}$ & Solvente \\
\hline Xileno & BTEX & $\mathrm{C}_{6} \mathrm{H}_{4}\left(\mathrm{CH}_{3}\right)_{2}$ & Vernizes, esmalte \\
\hline Zinco & Metal tóxico & $\mathrm{Zn}$ & Fungicida \\
\hline
\end{tabular}

TABELA 12 - Fundição e têmpera de ferro e aço

\begin{tabular}{|c|c|c|c|}
\hline Substância & Gr. Contaminante & Fórmula & Uso \\
\hline Acenafteno & PAH & $\mathrm{C}_{10} \mathrm{H}_{6}\left(\mathrm{CH}_{2}\right)_{2}$ & Tintas, corantes \\
\hline Acido Clorídrico & Ácido & $\mathrm{HCl}$ & Limpeza de metais \\
\hline Ácido Oxálico & Acido & $\mathrm{HOOCCOOH}{ }_{2} \mathrm{H}_{2} \mathrm{O}$ & Limpeza de metais \\
\hline Ácido Sulfúrico & Ácido & $\mathrm{H}_{2} \mathrm{SO}_{4}$ & Galvânica, metalurgia \\
\hline Antimônio & Metal tóxico & $\mathrm{Sb}$ & Têmpera, ligas \\
\hline Antraceno & $\mathrm{PAH}$ & $\mathrm{C}_{6} \mathrm{H}_{4}(\mathrm{CH})_{2} \mathrm{C}_{6} \mathrm{H}_{4}$ & Fonte de coque e carbono \\
\hline Arsênio & Metal tóxico & As & Aditivo ligante, soldas \\
\hline Benzeno & BTEX & $\mathrm{C}_{6} \mathrm{H}_{6}$ & Solvente, detergentes \\
\hline Benzo (a) pireno & PAH & $\mathrm{C}_{20} \mathrm{H}_{12}$ & Combustivel, coque \\
\hline Berílio & Metal tóxico & $\mathrm{Be}$ & $\begin{array}{l}\text { Liga metálica } \\
\end{array}$ \\
\hline Bifenilas policloradas (PCB) & Hidr. Clor. Não Vol. & & Fluido isolante \\
\hline Boro & Outros Comp Inorg. & B & Cementaçäo de ferro \\
\hline Cádmio & Metal tóxico & $\mathrm{Cd}$ & Eletrodeposição de tinta \\
\hline Carbazol & Comp. Nitrogenado & $\left(\mathrm{C}_{6} \mathrm{H}_{4}\right)_{2} \mathrm{NH}$ & $\begin{array}{l}\text { Reagente } \\
\end{array}$ \\
\hline Chumbo & Metal tóxico & $\mathrm{Pb}$ & Liga metálica, soldas \\
\hline Cianeto de Cálcio & Cianeto & $\mathrm{Ca}(\mathrm{CN})_{2}$ & Lixiviante para metais \\
\hline Cianeto de Sódio & Cianeto & $\mathrm{NaCN}$ & Limpeza de metais \\
\hline Cloretos & Organohalogenados & & \\
\hline Cobalto & Metal tóxico & $\mathrm{Co}$ & Ligas metal, cementação. \\
\hline Cobre & Metal tóxico & $\mathrm{Cu}$ & Galvânica, ligas metalicas \\
\hline Criseno & PAH & $\mathrm{C}_{18} \mathrm{H}_{12}$ & Sínteses orgânicas \\
\hline Cromo & Metal tóxico & $\mathrm{Cr}$ & Ligas metálicas \\
\hline Diclorometano & Solv. Org. Hal. & $\mathrm{CH}_{2} \mathrm{Cl}_{2}$ & Solvente, desengraxante \\
\hline Estanho & Metal tóxico & $\mathrm{Sn}$ & Ligas metálicas \\
\hline Fenantreno & PAH & $\mathrm{C}_{14} \mathrm{H}_{10}$ & Tingimento \\
\hline Fenol & Comp. Org. Arom. & $\mathrm{C}_{6} \mathrm{H}_{5} \mathrm{OH}$ & Solvente, resinas \\
\hline Fluoranteno & $\mathrm{PAH}$ & $\mathrm{C}_{16} \mathrm{H}_{10}$ & Combustivel \\
\hline Fluoreno-1 & $\mathrm{PAH}$ & $\mathrm{C}_{6} \mathrm{H}_{4} \mathrm{CH}_{2} \mathrm{C}_{6} \mathrm{H}_{4}$ & Tintas, corantes \\
\hline Fluoreto -2 & Halogenado & $F$ & Produção de metálicos \\
\hline Hexacloreto de Benzeno - 1 & Solv. Org. Hal. & $\mathrm{C}_{6} \mathrm{Cl}_{6}$ & Sínteses orgânicas \\
\hline
\end{tabular}




\begin{tabular}{l|l|l|}
\hline Manganês & Metal tóxico & $\mathrm{Mn}$ \\
\hline Mercúrio & Metal tóxico & $\mathrm{Hg}$ \\
\hline Molibdênio & Metal tóxico & $\mathrm{Mo}$ \\
\hline Nafta -2 & Derivado de Petróleo & \\
\hline Niquel & Metal tóxico & $\mathrm{Ni}$ \\
\hline Pentaclorofenol & Hidr. Clor. Nâo Vol. & $\mathrm{C}_{6} \mathrm{Cl} \mathrm{OH}_{5} \mathrm{OH}$ \\
\hline Selênio & Metal tóxico & $\mathrm{Se}$ \\
\hline Sulfatos & Comp. Sulfurado & \\
\hline Titânio & Metal tóxico & $\mathrm{Ti}$ \\
\hline Tolueno & BTEX & $\mathrm{CH}_{3} \mathrm{C}_{6} \mathrm{H}_{5}$ \\
\hline Tricloroetano & Solv. Org. Hal. & $\mathrm{CHCCl}_{2} \mathrm{CH}_{2} \mathrm{Cl}$ \\
\hline Tricloroetileno & Solv. Org. Hal. & $\mathrm{CHCll}_{\mathrm{CCCl}}$ \\
\hline Vanádio & Metal tóxico & $\mathrm{V}$ \\
\hline Xileno & BTEX & $\mathrm{C}_{6} \mathrm{H}_{4}\left(\mathrm{CH}_{3}\right)_{2}$ \\
\hline Zinco & Metal tóxico & $\mathrm{Zn}$ \\
\hline
\end{tabular}

Ferroligas, ligas $n$ /ferrosos

Amalgamas

Ligas metálicas

Thinner

Ligas metálicas

Bactericida, algicida

Aciaria, acelerador e catal.

Ligas metálicas

Solvente, resinas

Solvente, desengraxante

Solvente, desengraxante

Ligas metálicas

Solvente, esmalte

Galvânica, ligas metálicas

\section{TABELA 13 - Oficinas mecânicas e garagens de veículos}

\section{Substância}

Acenafteno

Antraceno

Benzeno

Benzo (a) pireno

Bifenilas Policloradas (PCB)

Chumbo

Criseno

Diesel

Fenantreno

Fluoranteno

Fluoreno

Naftaleno

Oleo Mineral

Tolueno

Xileno

\section{Gr. Contaminante Fórmula}

$\mathrm{PAH}$

Hidr. Arom. Polin.

BTEX

$\mathrm{PAH}$

Hidr. Clor. Não Vol.

Metal tóxico

PAH

Derivado de Petróleo

PAH

PAH

PAH

PAH

Derivado de Petróleo

BTEX

BTEX
$\mathrm{C}_{10} \mathrm{H}_{6}\left(\mathrm{CH}_{2}\right)_{2}$

$\mathrm{C}_{6} \mathrm{H}_{4}(\mathrm{CH})_{2} \mathrm{C}_{6} \mathrm{H}_{4}$

$\mathrm{C}_{6} \mathrm{H}_{6}$

$\mathrm{C}_{20} \mathrm{H}_{12}$

$\mathrm{Pb}$

$\mathrm{C}_{18} \mathrm{H}_{12}$

$\mathrm{C}_{14} \mathrm{H}_{10}$

$\mathrm{C}_{16} \mathrm{H}_{10}$

$\mathrm{C}_{6} \mathrm{H}_{4} \mathrm{CH}_{2} \mathrm{C}_{6} \mathrm{H}_{4}$

$\mathrm{C}_{10} \mathrm{H}_{8}$

$\mathrm{CH}_{3} \mathrm{C}_{6} \mathrm{H}_{5}$

$\mathrm{C}_{6} \mathrm{H}_{4}\left(\mathrm{CH}_{3}\right)_{2}$
Uso

Tintas, plásticos

Tintas, combustiveis

Solvente, detergente

Combustivel

Fluido isolante

Solda, baterias

Combustivel

Combustivel

Pinturas, resinas

Combustivel

Pinturas, resinas

Lubrificantes, graxas

Lubrificantes, graxas

Solvente, combustivel

Solvente, combustivel

\section{TABELA 14 - Lavanderia industrial}

\begin{tabular}{|c|c|c|c|}
\hline Substância & Gr. Contaminante & Fórmula & Uso \\
\hline Ácido sulfúrico & Ácido & $\mathrm{H}_{2} \mathrm{SO}_{4}$ & \\
\hline Amônia & Comp. Nitrogenado & $\mathrm{NH}_{4}$ & \\
\hline Benzeno & BTEX & $\mathrm{C}_{6} \mathrm{H}_{6}$ & Detergentes sintéticos \\
\hline Benzina & Derivado de Petróleo & & Solvente \\
\hline Bifenilas policloradas (PCB) & Hidr. Clor. Não Vol. & & Fluído isolante \\
\hline Chumbo & Metal tóxico & $\mathrm{Pb}$ & \\
\hline Cianeto de Cálcio & Cianeto & $\mathrm{Ca}(\mathrm{CN})_{2}$ & \\
\hline Cianeto de Potássio & Cianeto & $\mathrm{KCN}$ & \\
\hline Cianeto de Sodio & Cianeto & $\mathrm{NaCN}$ & Removedor, desengraxante \\
\hline Clorofórmio & Solv. Org. Hal. & $\mathrm{CHCl}_{2}$ & Tingimentos \\
\hline Cobre & Metal tóxico & $\mathrm{Cu}$ & \\
\hline Cromo & Metal tóxico & $\mathrm{Cr}$ & \\
\hline Diclorometano & Solv. Org. Hal. & $\mathrm{CH}_{2} \mathrm{Cl}_{2}$ & Removedor, desengraxante \\
\hline Formaldeído & Aldeido & $\mathrm{HCHO}$ & \\
\hline Hidroxido de Potássio & Outros Comp. Inorg. & $\mathrm{KOH}$ & Sabão \\
\hline Hidroxido de Sódio & Outros Comp Inorg. & $\mathrm{NaOH}$ & Sabão \\
\hline Naftaleno & PAH & $\mathrm{C}_{10 \mathrm{H}_{8}}$ & Quebra de emulsão \\
\hline Niquel & Metal tóxico & $\mathrm{Ni}$ & \\
\hline Percloroetileno & Solv. Org. Hal & $\mathrm{Cl}_{2} \mathrm{C}: \mathrm{CCl}_{2}$ & Solvente \\
\hline Selênio & Metal tóxico & $\mathrm{Se}$ & \\
\hline Tetraclorometano & Solv. Org. Hal. & $\mathrm{CCl}_{4}$ & Desengraxante \\
\hline Tolueno & BTEX & $\mathrm{CH}_{3} \mathrm{C}_{6} \mathrm{H}_{5}$ & Solvente \\
\hline Tricloroetano & Solv Org. Hal. & $\mathrm{CHCl}_{2} \mathrm{CH}_{2} \mathrm{Cl}$ & \begin{tabular}{|l|} 
Solvente \\
\end{tabular} \\
\hline Tricloroetileno & Solv. Org. Hal. & $\mathrm{CHCl}: \mathrm{CCl}_{2}$ & Limpeza a seco \\
\hline Xileno & BTEX & $\mathrm{C}_{6} \mathrm{H}_{4}\left(\mathrm{CH}_{3}\right)_{2}$ & Solvente \\
\hline Zinco & Metal tóxico & $\mathrm{Zn}$ & \\
\hline
\end{tabular}




\begin{tabular}{|c|c|c|c|}
\hline Substância & Gr. Contaminante & Fórmula & Uso \\
\hline Ácido Cloridrico & Acido & $\mathrm{HCl}$ & Desengraxante \\
\hline Ácido Fosfórico & Ácido & $\mathrm{H}_{3} \mathrm{PO}_{4}$ & Detergentes, sabões \\
\hline Ácido Sulfürico & Ácido & $\mathrm{H}_{2} \mathrm{SO}_{4}$ & Decapante, solvente, liga \\
\hline Arsênio & Metal tóxico & As & \\
\hline Benzeno & BTEX & $\mathrm{C}_{6} \mathrm{H}_{6}$ & Solvente, detergente sintético \\
\hline Benzina & Derivado de Petróleo & & Solvente ou extrator metálico \\
\hline Berílio & Metal tóxico & $\mathrm{Be}$ & \\
\hline Bifenila policlorada (PCB) & Hidr. Clor. Não Vol. & & \\
\hline Bis - $(2$ - cloroisopropil $)$ - éter & Solv. Org. Hal. & $\mathrm{ClCH}_{2} \mathrm{C}\left(\mathrm{CH}_{3} \mathrm{H}\right)_{2} \mathrm{O}$ & Solvente \\
\hline Cloreto de Alila & Organohalogenado & $\mathrm{CH}_{2} \mathrm{CHCH}_{2} \mathrm{Cl}$ & \\
\hline Clorobenzeno & Solv. Org. Hal.. & $\mathrm{C}_{6} \mathrm{H}_{5} \mathrm{Cl}$ & Solvente \\
\hline Clorofórmio & Solv. Org. Hal.. & $\mathrm{CHCl}_{2}$ & Solvente \\
\hline Cloropreno & Organohalogenado & $\mathrm{H}_{2} \mathrm{C}: \mathrm{CHCCl}: \mathrm{CH}_{2}$ & \\
\hline Cobalto & Metal tóxico & Co & Agente oxidante \\
\hline Cobre & Metal tóxico & $\mathrm{Cu}$ & \\
\hline Dicloroetano & Solv. Org. Hal. & $\mathrm{ClCH}_{2} \mathrm{CH}_{2} \mathrm{Cl}$ & Solvente \\
\hline Diclorometano & Solv. Org. Hal. & $\mathrm{CH}_{2} \mathrm{Cl}_{2}$ & Desengraxante \\
\hline Epicloridrina & Solv. Org. Hal. & $\mathrm{CH}_{2} \mathrm{OCHCH}_{2} \mathrm{Cl}$ & $\begin{array}{l}\text { Solvente } \\
\end{array}$ \\
\hline Etilenocloridrina & Solv. Org. Hal. & $\mathrm{ClCH}_{2} \mathrm{CH}_{2} \mathrm{OH}$ & Solvente \\
\hline Hexacloreto de Benzeno & Solv. Org. Hal. & $\mathrm{C}_{6} \mathrm{Cl}_{6}$ & Solvente \\
\hline Hidrazina & Comp. Nitrogenado & $\mathrm{H}_{2} \mathrm{NNH}_{2}$ & Inibidor de Corrosão \\
\hline Manganês & Metal tóxico & $\mathrm{Mn}$ & Protetivo \\
\hline Mercúrio & Metal tóxico & $\mathrm{Hg}$ & Produção soda e cloro \\
\hline Molibdênio & Metal tóxico & Mo & \\
\hline Níquel & Metal tóxico & $\mathrm{Ni}$ & \\
\hline Pentaclorofenol & Hidr. Clor. Não Vol. & $\mathrm{C}_{6} \mathrm{Cl}_{5} \mathrm{OH}$ & Fungicida, bactericida \\
\hline Percloroetileno & Solv. Org. Hal & $\mathrm{Cl}_{2} \mathrm{C}: \mathrm{CCl}_{2}$ & Solvente \\
\hline Prata & Metal tóxico & $\mathrm{Ag}$ & \\
\hline Tálio & Metal tóxico & $\mathrm{Ta}$ & \\
\hline Tetraclorometano & Solv. Org. Hal. & $\mathrm{CCl}_{4}$ & Desengraxante \\
\hline Tolueno & BTEX & $\mathrm{CH}_{3} \mathrm{C}_{6} \mathrm{H}_{5}$ & $\begin{array}{l}\text { Solvente } \\
\end{array}$ \\
\hline Tricloetano & Solv. Org. Hal. & $\mathrm{CHCl}_{2} \mathrm{CH}_{2} \mathrm{Cl}$ & Solvente \\
\hline Tricloroetileno & Solv. Org. Hal. & $\mathrm{CHCl}: \mathrm{CCl}_{2}$ & Desengraxante \\
\hline Trinitrotolueno & Comp. Nitrogenado & $\mathrm{CH}_{3} \mathrm{C}_{6} \mathrm{H}_{2}\left(\mathrm{NO}_{2}\right)_{3}$ & Desengraxante \\
\hline Vanádio & Metal tóxico & $\mathrm{V}$ & Catalizador \\
\hline Xileno & BTEX & $\mathrm{C}_{6} \mathrm{H}_{4}\left(\mathrm{CH}_{3}\right)_{2}$ & Solvente \\
\hline
\end{tabular}

TABELA 16 - Indústria Eletrotécnica

\begin{tabular}{|c|c|c|c|}
\hline Substância & Gr. Contaminante & Fórmula & Uso \\
\hline Ácido Cloriadrico & Ácido & $\mathrm{HCl}$ & Limpeza de metais \\
\hline Ácido Crômico & Acido & $\mathrm{CrO}_{3}$ & Anodização, capeamento \\
\hline Ácido Fórmico & Acido & $\mathrm{HCOOH}$ & Galvânica, plastificante \\
\hline Ácido Nitrico & Acido & $\mathrm{HNO}_{3}$ & Corrosão de metais \\
\hline Ácido Sulfúrico & Ácido & $\mathrm{H}_{2} \mathrm{SO}_{4}$ & Galvânica, metalurgia \\
\hline Amônia & Comp. Nitrogenado & $\mathrm{NH}_{4}$ & Condensação catalítica \\
\hline Anidrido Acético & Anidrido & $\left(\mathrm{CH}_{3} \mathrm{CO}\right)_{2} \mathrm{O}$ & Tintas, plásticos \\
\hline Antimônio & Metal tóxico & $\mathrm{Sb}$ & Semicondutores, soldas \\
\hline Arsênio & Metal tóxico & As & Semicondutores, soldas \\
\hline Asbesto & Outros Comp. Inorg. & & Agente de reforço \\
\hline Bário & Metal tóxico & $\mathrm{Ba}$ & Têmpera, desoxidante \\
\hline Benzeno & BTEX & $\mathrm{C}_{6} \mathrm{H}_{6}$ & Solvente, detergente sintético \\
\hline Benzina & Derivado de Petróleo & & Solvente \\
\hline Berilio & Metal tóxico & $\mathrm{Be}$ & Liga, computadores \\
\hline Bifenilas policloradas (PCB) & Hidr. Clor. Não Vol. & & $\begin{array}{l}\text { Fluido isolante } \\
\end{array}$ \\
\hline Boro & Outros Comp. Inorg. & B & Semicondutores, deoxidante \\
\hline Bromo & Outros Comp. Inorg. & $\mathrm{Br}$ & Solvente, branqueador \\
\hline Cádmio & Metal tóxico & $\mathrm{Cd}$ & Baterias, plásticos, borracha \\
\hline Chumbo & Metal tóxico & $\mathrm{Pb}$ & Liga, baterias, soldas \\
\hline Cianeto de Cálcio & Cianeto & $\mathrm{Ca}(\mathrm{CNO} 2$ & Lixiviante de metais \\
\hline Cianeto de Potássio & Cianeto & KCN & Extrator metálico \\
\hline
\end{tabular}




\begin{tabular}{|c|c|c|}
\hline Claneto de Sódio & Cianeto & $\mathrm{NaCN}$ \\
\hline Cloretos & Organohalogenado & \\
\hline Clorofórmio & Solv. Org. Hal.. & $\mathrm{C}_{10} \mathrm{H}_{7} \mathrm{Cl}$ \\
\hline Cobalto & Metal tóxico & Co \\
\hline Cobre & Metal tóxico & $\mathrm{Cu}$ \\
\hline Cresol & Fenol & $\mathrm{CH}_{3} \mathrm{C}_{6} \mathrm{H}_{4} \mathrm{OH}$ \\
\hline Cromo & Metal tóxico & $\mathrm{Cr}$ \\
\hline Dibenzo Dioxina Policlorada (PCDD) & Dioxinas & \\
\hline Diclorometano & Comp. Org. Hal Vol. & $\mathrm{CH}_{2} \mathrm{Cl}_{2}$ \\
\hline Diisocianato de 4,4-difenilmetano & Cianeto & $\mathrm{CH}_{2}\left(\mathrm{C}_{6} \mathrm{H}_{4} \mathrm{NCO}\right)_{2}$ \\
\hline Estanho & Metal tóxico & $\mathrm{Sn}$ \\
\hline Estireno & BTEX & $\left(\mathrm{C}_{6} \mathrm{H}_{5} \mathrm{CH}: \mathrm{CH}_{2}\right) \mathrm{n}$ \\
\hline Etilenoglicol & Álcool & $\mathrm{CH}_{2} \mathrm{OHCH}_{2} \mathrm{OH}$ \\
\hline Fenol & Fenol & $\mathrm{C}_{6} \mathrm{H}_{5} \mathrm{OH}$ \\
\hline Fluoreto & Halogenado & $F$ \\
\hline Hidroxido de Potássio & Outros Comp. Org. & $\mathrm{KOH}$ \\
\hline Hidroxido de Sódio & Outros Comp. Inorg. & $\mathrm{NaOH}$ \\
\hline Manganês & Metal tóxico & $\mathrm{Mn}$ \\
\hline Mercúrio & Metal tóxico & $\mathrm{Hg}$ \\
\hline Metanol & Álcool & $\mathrm{CH}_{3} \mathrm{OH}$ \\
\hline Molibdênio & Metal tóxico & Mo \\
\hline Níquel & Metal tóxico & $\mathrm{Ni}$ \\
\hline Óleo Mineral & Derivado de Petróleo & \\
\hline Percloroetileno & Solv. Org. Hal. & $\mathrm{Cl}_{2} \mathrm{C}: \mathrm{CCL}_{2}$ \\
\hline Piridina & Comp. Nitrogenado & $\mathrm{N}(\mathrm{CH})_{4} \mathrm{CH}$ \\
\hline Prata & $\begin{array}{l}\text { Metal tóxico } \\
\end{array}$ & $\mathrm{Ag}$ \\
\hline Selênio & Metal tóxico & $\mathrm{Se}$ \\
\hline Tálio & Metal tóxico & $\mathrm{TL}$ \\
\hline Telúrio & Metal tóxico & $\mathrm{Te}$ \\
\hline Tetraclorometano & Solv. Org. Hal. & $\mathrm{CCl}_{4}$ \\
\hline Titânio & Metal tóxico & $\mathrm{Ti}$ \\
\hline Tolueno & BTEX & $\mathrm{CH}_{3} \mathrm{C}_{6} \mathrm{H}_{5}$ \\
\hline Tricloroetano & Solv. Org. Hal. & $\mathrm{CHCl}_{2} \mathrm{CH}_{2} \mathrm{Cl}$ \\
\hline Tricloroetileno & Solv. Org. Hal. & $\mathrm{CHCl} \mathrm{CCl}_{2}$ \\
\hline Vanádio & Metal tóxico & $\mathrm{V}$ \\
\hline Xileno & BTEX & $\mathrm{C}_{6} \mathrm{H}_{4}\left(\mathrm{CH}_{3}\right)_{2}$ \\
\hline
\end{tabular}

Limpeza de metais

Solvente

Galvânica, ligas

Fios, cabos, Galvânica

Resinas fenólicas, surfact

Ligante p/plástico e metal

Solvente, desengraxante

Resina de poliuretano

Ligas metálicas

plásticos (ABS, SBR, SAN)

Solvente, vernizes, adesivo

Solvente, tintas

Produção Metálicos

Galvânica

Eletrogalvanização, resina

Ferroligas

Amalgamas, Lâmpadas

Solvente

Ligas, tintas

Baterias, tintas, ligas

Lubrificante, protetivo

Solvente, secante $\mathrm{p} / \mathrm{m}$ etais

Solvente

Galvânica, baterias

Baterias, catalizador

Eletrodo

Ligas, baterias

Desengraxante

Ligas, cerâmica

Solvente, colas, resinas

Solvente, desengraxante

Secante, desengraxante

Ligas, catalizador

Solvente, vernizes

TABELA 17 - Fabricação de produtos de refrigeração

\section{Substância}

Bifenilas policloradas (PCB)

DibenzoDioxinas policlorada

Diclorometano

Etilenoglicol

Tetraclorometano

\section{Gr. Contaminante Fórmula}

Organohalogenado

Dioxinas

Solv. Org. Hal

Álcool

Organohalogenado

\begin{tabular}{|l|l|}
\hline Fórmula \\
\\
\hline \\
\hline $\mathrm{CH}_{2} \mathrm{Cl}_{2}$ \\
\hline $\mathrm{CH}_{2} \mathrm{OHCH}_{2} \mathrm{OH}$ \\
\hline $\mathrm{CCl} 4$ \\
\hline
\end{tabular}

Uso

Isolante equipamento elétrico

Agente soprador espumas

Agente de refrigeração

Solvente, desengraxante

\section{TABELA 18 - Indústria Elétrica}

\section{Substância}

Ácido Clorídrico

Ácido Crômico

Ácido Fluorídrico

Ácido fosfórico

Ácido Sulfúrico

Antimônio

Arsênio

Benzeno

Bifenílas Policloradas (PCB)

Bis - (2-cloroisopropil) - éter

Cádmio

Chumbo

Cianetos

Cloreto de Alla

Clorobenzeno

.

\section{Tústra Eletrica}




\begin{tabular}{|c|c|c|}
\hline Clorofórmio & Solv. Org. Hal. & $\mathrm{CHCl}_{2}$ \\
\hline Cloropreno & Solv Org. Hal. & $\mathrm{H}_{2} \mathrm{C}: \mathrm{CHCCl}: \mathrm{CH}_{2}$ \\
\hline Cobalto & Metal tóxico & Co \\
\hline Cobre & Metal tóxico & $\mathrm{Cu}$ \\
\hline Cromato & Metal tóxico & \\
\hline Cromo & Metal tóxico & $\mathrm{Cr}$ \\
\hline DibenzoDioxinas policlorada & Dioxinas & \\
\hline Dicloroetano & Solv. Org. Hal. & $\mathrm{ClCH}_{2} \mathrm{CH}_{2} \mathrm{Cl}$ \\
\hline Diclorometano & Solv. Org. Hal. & $\mathrm{CH}_{2} \mathrm{Cl}_{2}$ \\
\hline Dicloropropano & Solv. Org. Hal. & $\mathrm{CH}_{3} \mathrm{CHClCH}_{2} \mathrm{Cl}$ \\
\hline Diisocianato & Cianeto & $\mathrm{NCO}$ \\
\hline Epicloridrina & Solv. Org. Hal. & $\mathrm{CH}_{2} \mathrm{CHCH}_{2} \mathrm{Cl}$ \\
\hline Estanho & Metal tóxico & $\mathrm{Sn}$ \\
\hline Estireno & BTEX & $\left(\mathrm{C}_{6} \mathrm{H}_{5} \mathrm{CH}: \mathrm{CH}_{5}\right) \mathrm{n}$ \\
\hline Etilenoglicol & Álcool & $\mathrm{CH}_{2} \mathrm{OHCH}_{2} \mathrm{OH}$ \\
\hline Hexacloreto de Benzeno & Hidr. Clor. Não Vol. & $\mathrm{C}_{6} \mathrm{Cl}_{6}$ \\
\hline Hidróxido de Potássio & Outros Comp. Org. & $\mathrm{KOH}$ \\
\hline Hidróxido de Sódio & Outros Comp. Inorg. & $\mathrm{NaOH}$ \\
\hline Manganês & Metal tóxico & $\mathrm{Mn}$ \\
\hline Mercaptana & Comp. Sulfurado & \\
\hline Mercúrio & Metal tóxico & $\mathrm{Hg}$ \\
\hline Molibdênio & Metal tóxico & Mo \\
\hline Níquel & Metal tóxico & $\mathrm{Ni}$ \\
\hline Pentaclorofenol & Hidr. Clor. Não Vol. & $\mathrm{C}_{6} \mathrm{Cl}_{5} \mathrm{OH}$ \\
\hline Percloroetileno & Solv. Org. Hal. & $\mathrm{Cl}_{2} \mathrm{C}: \mathrm{CCl}_{2}$ \\
\hline Piridina & Comp. Nitrogenado & $\mathrm{N}(\mathrm{CH})_{4} \mathrm{CH}$ \\
\hline Prata & Metal tóxico & $\mathrm{Ag}$ \\
\hline Telúrio & Metal tóxico & $\mathrm{Te}$ \\
\hline Tetraclorometano & Solv. Org. Hal. & $\mathrm{CCl}_{4}$ \\
\hline Tolueno & BTEX & $\mathrm{CH}_{3} \mathrm{C}_{6} \mathrm{H}_{5}$ \\
\hline Tricloroetano & Solv. Org. Hal. & $\mathrm{CHCl}_{2} \mathrm{CH}_{2} \mathrm{Cl}$ \\
\hline Tricloroetileno & Solv. Org. Hal. & $\mathrm{CHCl}: \mathrm{CCl}_{2}$ \\
\hline Urânio & Metal tóxico & Ur \\
\hline Vanádio & Metal tóxico & $\mathrm{V}$ \\
\hline Xileno & BTEX & $\mathrm{C}_{6} \mathrm{H}_{4}\left(\mathrm{CH}_{3}\right)_{2}$ \\
\hline Zinco & Metal tóxico & $\mathrm{Zn}$ \\
\hline
\end{tabular}

Solvente Solvente

Galvânica, ligas metálicas Galvânica, ligas, fios cabos

Ligante metal e plástico

Fixador de cor p/plástico

Solvente, desengraxante

Solvente, desengraxante

Produção de espumas

Resinas epoxi e fenólicas

Ligas metálicas

plásticos, resinas

Solvente, refrigeração

Sinteses orgânicas

Galvânica, sabão

Eletrogalvânica, sabão

Ferroligas

Lâmpadas, amalgamas

Ligas $p /$ altas temperaturas

Magnetos, baterias

Preservativo $\mathrm{p} / \mathrm{madeira}$

Solvente, secante p/metais

Solvente

Baterias

Baterias

Solvente, semicondutores

Solvente, resinas

Solvente, resinas

Secante

Ligas metálicas

Solvente, resina alquidica

Baterias, anodos

TABELA 19 - Lava rápido de veículos

\section{Substância}

Benzina

Cresol

Diclorometano

Percloroetileno

Querosene

Tetraclorometano

Tricloroetano

Tricloroetileno

\section{Gr. Contaminante}

Derivado de Petróleo

Fenol

Solv. Org. Hal

Solv. Org. Hal

Derivado de Petróleo

Solv. Org. Hal

Solv. Org. Hal

Solv. Org. Hal
Fórmula

$\mathrm{CH}_{3} \mathrm{C}_{6} \mathrm{H}_{4} \mathrm{OH}$

$\mathrm{CH}_{2} \mathrm{Cl}_{2}$

$\mathrm{Cl}_{2}: \mathrm{CCl}_{2}$

$\mathrm{CCl}_{4}$

$\mathrm{CHCl}_{2} \mathrm{CH}_{2} \mathrm{Cl}$

$\mathrm{CHCl}_{2} \mathrm{CCl}_{2}$

\section{Uso}

Solvente, extrator

Desinfetante, surfactante

Solvente, desengraxante.

Solvente

Solvente

Solvente, desengraxante

Solvente, desengraxante.

Limpeza seco, desengraxante

TABELA 20 - Fabricação de esquadrias metálicas e de madeira

\section{Substância}

Antimônio

Arsênio

Bifenílas policloradas

Bis - (2-cloroisopropil) - éter

Cádmio

Chumbo

Cloreto de Alila

Clorofórmio

Cloronaftaleno

Cloropreno

Cobalto

Cobre

Cromo

\section{Gr. Contaminante Fórmula}

Metal tóxico

Metal tóxico

Organohalogenado

Solv. Org. Hal.

Metal tóxico

Metal tóxico

Solv. Org. Hal.

Solv. Org. Hal.

PAH

Solv. Org. Hal

Metal tóxico

Metal tóxico

Metal tóxico

\begin{tabular}{|l|}
\hline Fórmula \\
\hline $\mathrm{Sb}$ \\
\hline $\mathrm{As}$ \\
\\
\hline $\mathrm{ClCH}{ }_{2} \mathrm{C}\left(\mathrm{CH}_{3} \mathrm{H}_{2}\right.$ \\
\hline $\mathrm{Cd}$ \\
\hline $\mathrm{Pb}$ \\
\hline $\mathrm{CH}_{2} \mathrm{CHCH}{ }_{2} \mathrm{Cl}$ \\
\hline $\mathrm{CHCl}_{2}$ \\
\hline $\mathrm{C}_{10} \mathrm{H}_{7} \mathrm{Cl}$ \\
\hline $\mathrm{H}_{2} \mathrm{C}: \mathrm{CHCCl}: \mathrm{CH}_{2}$ \\
\hline $\mathrm{Co}$ \\
\hline $\mathrm{Cu}$ \\
\hline $\mathrm{Cr}$ \\
\hline
\end{tabular}

Uso

Solda

Solda

Fluido isolante

Removedor de tinta e verniz

Eletrodeposição de tinta

Solda, chapas

Solvente $p /$ resinas

Solvente, tingimento

Ceras

Tintas e vernizes

Tintas protetivas

Aço-inox 


\begin{tabular}{|c|c|c|c|}
\hline Diclorodifenil Tricloroetano (DDT) & Pesticida & $\left(\mathrm{ClC}_{6} \mathrm{H}_{4}\right)_{2} \mathrm{CHCCl}_{3}$ & Fumigação, conservante \\
\hline Dicloroetano & Solv. Org. Hal. & $\mathrm{ClCH}_{2} \mathrm{CH}_{2} \mathrm{Cl}$ & Solvente \\
\hline Diclorometano & Solv. Org. Hal. & $\mathrm{CH}_{2} \mathrm{Cl}_{2}$ & Removedor de tinta e verniz \\
\hline Dicloropropano & Solv. Org. Hal. & $\mathrm{CH}_{3} \mathrm{CHClCH} \mathrm{Cl}_{2} \mathrm{Cl}$ & Solvente, desengraxante \\
\hline Diisocianato & Cianeto & $\mathrm{NCO}$ & Espuma de poliuretano \\
\hline Epicloridrina & Solv. Org. Hal. & $\mathrm{CH}_{2} \mathrm{OCH}_{4} \mathrm{CH}_{2} \mathrm{Cl}$ & Solvente, resinas \\
\hline Estireno & BTEX & $\left(\mathrm{C}_{6} \mathrm{H}_{5} \mathrm{CH}_{\mathrm{C}} \mathrm{CH}_{2}\right) \mathrm{n}$ & Tintas, plásticos \\
\hline Etilenocloridrina & Solv. Org. Hal. & $\mathrm{ClCH}_{2} \mathrm{CH}_{2} \mathrm{OH}$ & Solvente \\
\hline Hexacloreto de Benzeno & Hidr. Clor. Não Vol. & $\mathrm{C}_{6} \mathrm{Cl}_{6}$ & \\
\hline Lindano & Pesticida & $\mathrm{C}_{6} \mathrm{H}_{6} \mathrm{Cl}_{6}$ & Inseticida \\
\hline Manganês & Metal tóxico & $\mathrm{Mn}$ & Ferroligas \\
\hline Molibdênio & Metal tóxico & Mo & Tintas, pigmentos \\
\hline Pentaclorofenol & Hidr. Clor. Não Vol. & $\mathrm{C}_{6} \mathrm{Cl}_{5} \mathrm{OH}$ & Preservativo de madeira \\
\hline Prata & Metal tóxico & $\mathrm{Ag}$ & Galvânica \\
\hline Tálio & Metal tóxico & $\mathrm{Tl}$ & Ligas metálicas \\
\hline Telúrio & Metal tóxico & $\mathrm{Te}$ & Ligas metálicas \\
\hline Tetracloroetileno & Solv. Org. $\mathrm{Hal}$. & $\mathrm{Cl}_{2} \mathrm{C}: \mathrm{CCl}_{2}$ & Solvente \\
\hline Tetraclorometano & Solv. Org. Hal. & $\mathrm{CCl}_{4}$ & Solvente, desengraxante \\
\hline Tricloroetano & Solv. Org. Hal. & $\mathrm{CHCl}_{2} \mathrm{CH}_{2} \mathrm{Cl}$ & Solvente, desengraxante \\
\hline Tricloroetileno & Solv. Org. Hal. & $\mathrm{CHCl}: \mathrm{CCl}_{2}$ & Limpeza a seco, ceras \\
\hline Triclorofenol & Hidr. Clor. Não Vol. & $\mathrm{C}_{6} \mathrm{H}_{2} \mathrm{Cl}_{3} \mathrm{OH}$ & Fungicida \\
\hline Vanádio & Metal tóxico & $\mathrm{V}$ & Borracha sintética \\
\hline Zinco & Metal tóxico & $\mathrm{Zn}$ & Fungicida \\
\hline
\end{tabular}

TABELA 21 - Fabricação de óleo mineral, industriais, protetivos, dedicados, lubrificantes

\begin{tabular}{|c|c|c|c|}
\hline Substância & Gr. Contaminante & Fórmula & Uso \\
\hline Ácido Sulfúrico & Acido & $\mathrm{H}_{2} \mathrm{SO}_{4}$ & Agente coagulante \\
\hline Antraceno & $\mathrm{PAH}$ & $\mathrm{C}_{6} \mathrm{H}_{4}\left(\mathrm{CH}_{2}\right) \mathrm{C}_{6} \mathrm{H}_{4}$ & Combustivel Industrial \\
\hline Arsênio & Metal tóxico & As & Aditivo ligante $\mathrm{p} /$ metais \\
\hline Benzeno & BTEX & $\mathrm{C}_{6} \mathrm{H}_{6}$ & Solvente \\
\hline Benzo (a) pireno & PAH & $\mathrm{C}_{2} \mathrm{OH}_{12}$ & Combustivel \\
\hline Bifenilas policioradas & Hidr. Clor Não Vol. & & Fluído isolante \\
\hline Bis - $(2$ - cloroisopropil $)$ - éter & Solv. Org. Hal. & $\mathrm{ClCH}_{2} \mathrm{C}\left(\mathrm{CH}_{3} \mathrm{H}\right)_{2} \mathrm{O}$ & Solvente p/óleo e graxas \\
\hline Cianetos & Cianeto & & \\
\hline Cloreto de Alila & Solv. Org. Hal. & $\mathrm{CH}_{2} \mathrm{CHCH}_{2} \mathrm{Cl}$ & \\
\hline Clorobenzeno & Solv. Org. Hal. & $\mathrm{C}_{6} \mathrm{H}_{5} \mathrm{Cl}$ & Solvente \\
\hline Cloropreno & Solv. Org. Hal. & $\mathrm{H}_{2} \mathrm{C}: \mathrm{CHCCl} \mathrm{CH}_{2}$ & \\
\hline Dicloroetano & Solv. Org. Hal. & $\mathrm{ClCH}_{2} \mathrm{CH}_{2} \mathrm{Cl}$ & Solvente $p /$ éster \\
\hline Diclorometano & Solv. Org. Hal. & $\mathrm{CH}_{2} \mathrm{Cl}_{2}$ & Agente separador espuma \\
\hline Epicloridrina & Solv Org. $\mathrm{Hal}$ & $\mathrm{CH}_{2} \mathrm{OCHCH} \mathrm{Cl}_{2}$ & Solvente $\mathrm{p} /$ éster \\
\hline Etilenocloridrina & Solv. Org. Hal. & $\mathrm{ClCh}_{2} \mathrm{CH}_{2} \mathrm{OH}$ & Solvente \\
\hline Fenol & Fenol & $\mathrm{C}_{6} \mathrm{H}_{5} \mathrm{OH}$ & Solvente seletivo $\mathrm{p} /$ óleos \\
\hline Heptano & Derivado de Petróleo & $\mathrm{CH}_{3}\left(\mathrm{CH}_{2}\right)_{5} \mathrm{CH}_{3}$ & Reagente, solvente \\
\hline Hexacloreto de benzeno & Hidr. Clor. Não Vol. & $\mathrm{C}_{6} \mathrm{Cl}_{6}$ & Sínteses orgânicas \\
\hline Hexano & Derivado de Petróleo & $\mathrm{CH}_{3}\left(\mathrm{CH}_{2}\right)_{4} \mathrm{CH}_{3}$ & Solvente \\
\hline Hidroxido de sódio & Outros Comp. Inorg. & $\mathrm{NaOH}$ & Refino de petróleo \\
\hline Pentaclorofenol & Solv. Org. Hal. & $\mathrm{C}_{6} \mathrm{Cl}_{5} \mathrm{OH}$ & Solvente \\
\hline Percloroetileno & Solv. Org. Hal. & $\mathrm{Cl}_{2} \mathrm{C}: \mathrm{CCl}_{2}$ & Solvente \\
\hline Tolueno & BTEX & $\mathrm{CH}_{3} \mathrm{C}_{6} \mathrm{H}_{5}$ & Solvente \\
\hline Tricloroetano & Solv. Org. Hal. & $\mathrm{CHCl}_{2} \mathrm{CH}_{2} \mathrm{Cl}$ & Solvente \\
\hline Tricloroetileno & Solv. Org. Hal. & $\mathrm{CHCl}: \mathrm{CCl}_{2}$ & Solvente \\
\hline Xileno & BTEX & $\mathrm{C}_{6} \mathrm{H}_{4}\left(\mathrm{CH}_{3}\right)_{2}$ & Solvente \\
\hline
\end{tabular}

TABELA 22 - Fabricação de plástico e borracha sintétíca

\begin{tabular}{l|l|l|l}
\hline Substância & Gr. Contaminante & Fórmula & Uso \\
\hline Ácido Benzosulfonico & Ácido & $\mathrm{C}_{6} \mathrm{H}_{5} \mathrm{SO}_{3} \mathrm{H}$ & \\
\hline Acido Fórmico & Acido & $\mathrm{HCOOH}$ & Resina vinilica \\
\hline Ácido Sulfúrico & Ácido & $\mathrm{H}_{2} \mathrm{SO}_{4}$ & Pigmentos inorgânicos \\
\hline Acrilonitrila & Cianeto & $\mathrm{H}_{2} \mathrm{C}: \mathrm{CHCN}$ & Copolimero, borracha nitrílica \\
\hline Acroleína & Aldeído & $\mathrm{CH}_{2} \mathrm{CHCHO}$ & Polímero \\
\hline Anidrido Acético & Anidrido & $\left(\mathrm{CH}_{3} \mathrm{CO}\right)_{2} \mathrm{O}$ & Plásticos fluorcarbonados \\
\hline Anidrido Ftálico & Ftalato & $\mathrm{C} 6 \mathrm{H}_{4}(\mathrm{CO}) 2 \mathrm{O}$ & Plastificante \\
\hline Anilina & Comp. Nitrogenado & $\mathrm{C}_{6} \mathrm{H}_{5} \mathrm{NH}_{2}$ & Antioxidante p/borracha \\
\hline
\end{tabular}




\begin{tabular}{|c|c|c|c|}
\hline Bário & Metal tóxico & $\mathrm{Ba}$ & \\
\hline Benzeno & BTEX & $\mathrm{C}_{6} \mathrm{H}_{6}$ & Estireno \\
\hline Bis - $(2$ - cloroisopropil $)$ - éter & Solv. Org. Hal. & $\mathrm{ClCH}_{2} \mathrm{C}\left(\mathrm{CH}_{3} \mathrm{H}\right)_{2} \mathrm{O}$ & Solvente \\
\hline Bisulfeto de Carbono & Comp. Sulfurado & $\mathrm{CS}_{2}$ & Flotação \\
\hline Boro & Outros Comp. Inorg. & $B$ & Desgaseificante \\
\hline Bromo & Outros Comp. Inorg. & $\mathrm{Br}$ & Branqueamento \\
\hline Cádmio & Metal tóxico & $\mathrm{Cd}$ & \\
\hline Chumbo & Metal tóxico & $\mathrm{Pb}$ & \\
\hline Cianeto de Cálcio & Cianeto & $\mathrm{Ca}(\mathrm{CN})_{2}$ & Lixiviante metálico \\
\hline Cianeto de Potássio & Cianeto & $\mathrm{KCN}$ & \\
\hline Cianeto de Sódio & Cianeto & $\mathrm{NaCN}$ & $\begin{array}{l}\text { Pigmento } \\
\end{array}$ \\
\hline Ciclohexanona & Cetona & $\mathrm{C}_{6} \mathrm{H}_{10} \mathrm{O}$ & Cloreto de polivinila \\
\hline Clorofórmio & Solv. Org. Hal. & $\mathrm{CHCl}_{2}$ & Plásticos fluorcarbonados \\
\hline Cloropreno & Solv. Org. Hal. & $\mathrm{H}_{2} \mathrm{C}: \mathrm{CHCCl}: \mathrm{CH}_{2}$ & \\
\hline Cobre & Metal tóxico & $\mathrm{Cu}$ & \\
\hline Cresol & Fenol & $\mathrm{CH}_{3} \mathrm{C}_{6} \mathrm{H}_{4} \mathrm{OH}$ & Resinas fenólicas \\
\hline Cromo & Metal tóxico & $\mathrm{Cr}$ & Elemento ligante $p /$ plástico \\
\hline Dibrometano & Solv. Org. Hal. & $\mathrm{CH}_{2} \mathrm{Br}_{2}$ & Sínteses orgânicas \\
\hline Dicloroetano & Solv. Org. Hal. & $\mathrm{ClCH}_{2} \mathrm{CH}_{2} \mathrm{Cl}$ & Cloreto de vinila \\
\hline Diclorometano & Solv Org. Hal. & $\mathrm{CH}_{2} \mathrm{Cl}_{2}$ & Agente soprador espumas \\
\hline Dicloropropano & Solv. Org. Hal. & $\mathrm{CH}_{3} \mathrm{CHClCH}{ }_{2} \mathrm{Cl}$ & Solvente \\
\hline Diisocianato de 4,4 - difenilmetano & Cianeto & $\mathrm{CH}_{2}\left(\mathrm{C}_{6} \mathrm{H}_{4} \mathrm{NCO}\right)_{2}$ & Resina poliuretano \\
\hline Diisocianato de Tolueno & Cianeto & $\mathrm{CH}_{3} \mathrm{C}_{6} \mathrm{H}_{3}(\mathrm{NCO})_{2}$ & Espumas de poliuretano \\
\hline Epicloridrina & Solv. Org. Hal. & $\mathrm{CH}_{2} \mathrm{OCHCH}_{2} \mathrm{Cl}$ & Resina epoxi, fenólica \\
\hline Estireno & BTEX & $\left(\mathrm{C}_{6} \mathrm{H}_{5} \mathrm{CH}: \mathrm{CH}_{2}\right) \mathrm{n}$ & $A B S, S B R, S A N$ \\
\hline Etilenocloridrina & Solv. Org. Hal. & $\mathrm{ClCH}_{2} \mathrm{CH}_{2} \mathrm{OH}$ & Solvente \\
\hline Fenol & Fenol & $\mathrm{C}_{6} \mathrm{H}_{5} \mathrm{OH}$ & Pentaclorofenol, resinas \\
\hline Fluoreto & PAH & $\mathrm{C}_{6} \mathrm{H}_{4} \mathrm{CH}_{2} \mathrm{C}_{6} \mathrm{H}_{4}$ & Resinas \\
\hline Formaldeido & Aldeido & $\mathrm{HCHO}$ & Resinas fenólicas \\
\hline Mercúrio & Metal tóxico & $\mathrm{Hg}$ & Amalgamas \\
\hline Nitrito & Comp. Nitrogenado & $\mathrm{NO}_{2}$ & \\
\hline Nitrotoluol & Comp. Nitrogenado & $\mathrm{NO}_{2} \mathrm{C}_{6} \mathrm{H}_{4} \mathrm{CH}_{3}$ & Sinteses orgânicas \\
\hline Oxido de Etileno & Óxido & $\mathrm{CH}_{3} \mathrm{CH}_{2} \mathrm{O}$ & Fibras poliester \\
\hline$P$-quinona & Cetona & $\mathrm{C}_{6} \mathrm{H}_{4} \mathrm{O}_{2}$ & Hidroquinona \\
\hline Selênio & Metal tóxico & $\mathrm{Se}$ & Catalizador e acelerador \\
\hline Tetraclorometano & Solv. Org. $\mathrm{Hal}$. & $\mathrm{CCl}_{4}$ & Solvente \\
\hline Titânio & Metal tóxico & $\mathrm{Ti}$ & Ligas metálicas \\
\hline Tolueno & BTEX & $\mathrm{CH}_{3} \mathrm{C}_{6} \mathrm{H}_{5}$ & Resinas \\
\hline
\end{tabular}

TABELA 23 - Serviços de funilaria e pintura de veículos

\begin{tabular}{l|l|l|}
\hline Substância & Gr. Contaminante & Fórmula \\
\hline Ácido Sulfúrico & Ácido & $\mathrm{H}_{2} \mathrm{SO}_{4}$ \\
\hline Benzeno & BTEX & $\mathrm{C}_{6} \mathrm{H}_{6}$ \\
\hline Benzina & Derivado de Petróleo & \\
\hline Diisocianato de 4,4 - difenilmetano & Cianeto & $\mathrm{CH}_{2}\left(\mathrm{C}_{6} \mathrm{H}_{4} \mathrm{NCO}_{2}\right.$ \\
\hline Estireno & BTEX & $\left(\mathrm{C}_{6} \mathrm{H}_{5} \mathrm{CH}: \mathrm{CH}_{2}\right) n$ \\
\hline Hidroxido de Sódio & Outros Comp. Inorg. & $\mathrm{NaOH}^{2}$ \\
\hline Tolueno & BTEX & $\mathrm{CH}_{3} \mathrm{C}_{6} \mathrm{H}_{5}$ \\
\hline Xileno & BTEX & $\mathrm{C}_{6} \mathrm{H}_{4}(\mathrm{CH} 3)_{2}$ \\
\hline
\end{tabular}

Uso

Limpeza, baterias

Solvente, detergentes Solvente

Resina poliuretano

Plásticos, tinta, resina

Sabão, resinas

Solvente, colas, resina

Solvente, resina

TABELA 24 - Indústria de reciclagem de tambores

\begin{tabular}{l} 
Substância \\
\hline Acido Sulfúrico \\
\hline Benzeno \\
\hline Hidróxido de Sódio \\
\hline Tolueno \\
\hline Xileno
\end{tabular}

Gr. Contaminante

Ácido

BTEX

Outros Comp Inorg.

BTEX

BTEX

\begin{tabular}{|l|l|}
\hline Fórmula & \\
\hline $\mathrm{H}_{2} \mathrm{SO}_{4}$ & \\
\hline $\mathrm{C}_{6} \mathrm{H}_{6}$ & \\
\hline $\mathrm{NaOH}_{0}$ & \\
\hline $\mathrm{CH}_{3} \mathrm{C}_{6} \mathrm{H}_{5}$ & \\
\hline $\mathrm{C}_{6} \mathrm{H}_{4}\left(\mathrm{CH}_{3}\right)_{2}$ &
\end{tabular}

Uso

Redução de metais

Solventes, detergentes

Sabão

Solventes

Solvente

TABELA 25 - Tratamentos mecânicos metal, estamparia, dobra, repuxo

\section{Substância}

Ácido Clorídrico

Ácido Sulfúrico

Antimónio

\section{Gr. Contaminante}

Ácido

Ácido

Metal tóxico

\section{Fórmula}

$\mathrm{HCl}$

$\mathrm{H}_{2} \mathrm{SO}_{4}$
Uso

Limpeza de metais

Corrosão de superfície Solda 


\begin{tabular}{|c|c|c|c|}
\hline Arsênio & Metal tóxico & As & Solda \\
\hline Benzeno & BTEX & $\mathrm{C}_{6} \mathrm{H}_{6}$ & Solvente \\
\hline Bifenilas policloradas (PCB) & Hidr. Clor. Não Vol. & & Fluído isolante \\
\hline Bis - 2 - cloroisopropil $)$ - éter & Solv. Org. Hal. & $\mathrm{ClCH}_{2} \mathrm{C}\left(\mathrm{CH}_{3} \mathrm{H}\right)_{2} \mathrm{O}$ & Desengraxante \\
\hline Cádmio & Metal tóxico & $\mathrm{Cd}$ & Eletrodeposição \\
\hline Chumbo & Metal tóxico & $\mathrm{Pb}$ & Solda, chaparia \\
\hline Cloreto de Alila & Organohalogenado & $\mathrm{CH}_{2} \mathrm{CHCH} 2 \mathrm{Cl}$ & Resinas termo-sensiveis \\
\hline Clorobenzeno & \begin{tabular}{|l} 
Solv. Org. Hal.. \\
\end{tabular} & $\mathrm{C}_{6} \mathrm{H}_{5} \mathrm{Cl}$ & $\begin{array}{l}\text { Solvente } \\
\end{array}$ \\
\hline Clorofórmio & Solv. Org. Hal. & $\mathrm{CHCl}_{2}$ & Solvente \\
\hline Cloropreno & Solv. Org. Hal. & $\mathrm{H}_{2} \mathrm{C}: \mathrm{CHCCl} \mathrm{CH}_{2}$ & \\
\hline Cobalto & Metal tóxico & Co 2 & Cementação, oxidante \\
\hline Cobre & Metal tóxico & $\mathrm{Cu}$ & \\
\hline Cromo & Metal tóxico & $\mathrm{Cr}$ & Ligante $\mathrm{p} /$ metais \\
\hline Dicloroetano & Solv. Org. Hal. & $\mathrm{ClCH}_{2} \mathrm{CH}_{2} \mathrm{Cl}$ & $\begin{array}{l}\text { Solvente } \\
\end{array}$ \\
\hline Diclorometano & Solv. Org. Hal. & $\mathrm{CH}_{2} \mathrm{Cl}_{2}$ & Solvente, removedor \\
\hline Dicloropropano & Solv. Org. Hal. & $\mathrm{CH}_{3} \mathrm{CHClCH}_{2} \mathrm{Cl}$ & Desengraxante \\
\hline Epicloridrina & Solv. Org. Hal. & $\mathrm{CH}_{2} \mathrm{OCHCH}_{2} \mathrm{Cl}$ & Solvente \\
\hline Etilenocloridrina & Solv. Org. Hal. & $\mathrm{ClCH}_{2} \mathrm{CH}_{2} \mathrm{OH}$ & Solvente \\
\hline Formaldeido & $\begin{array}{l}\text { Aldeido } \\
\end{array}$ & $\mathrm{HCHO}$ & Inibidor de Corrosão \\
\hline Hexacloreto de benzeno & Hidr. Clor. Nẫo Vol. & $\mathrm{C}_{6} \mathrm{Cl}_{6}$ & \\
\hline Hidroxido de Sódio & Outros Comp. Inorg. & $\mathrm{NaOH}$ & Corrosão de superfície \\
\hline Manganês & Metal tóxico & $\mathrm{Mn}$ & Têmpera e Corrosão \\
\hline Mercúrio & Metal tóxico & $\mathrm{Hg}$ & Amalgamas \\
\hline Molibdênio & Metal tóxico & Mo & Pigmentos, tintas \\
\hline Niquel & Metal tóxico & $\mathrm{Ni}$ & Tintas eletro-protetivas \\
\hline Pentaclorofenol & Hidr. Clor. Não Vol. & $\mathrm{C}_{6} \mathrm{Cl}_{5} \mathrm{OH}$ & \\
\hline Percloroetileno & Solv. Org. Hal. & $\mathrm{Cl}_{2} \mathrm{C}: \mathrm{CCl}_{2}$ & Secante $p /$ metais \\
\hline Prata & Metal tóxico & $\mathrm{Ag}$ & Têmpera \\
\hline Telúrio & Metal tóxico & $\mathrm{Te}$ & \\
\hline Tetraclorometano & Solv. Org. Hal. & $\mathrm{CCl}_{4}$ & Desengraxante \\
\hline Tolueno & BTEX & $\mathrm{CH}_{3} \mathrm{C}_{6} \mathrm{H}_{5}$ & \begin{tabular}{|l|} 
Solvente \\
\end{tabular} \\
\hline Tricloroetano & Solv. Org. Hal. & $\mathrm{CHCl}_{2} \mathrm{CH}_{2} \mathrm{Cl}$ & Desengraxante, solvente \\
\hline Tricloroetileno & Solv. Org. Hal. & $\mathrm{CHCl}: \mathrm{CCl}_{2}$ & Desengraxante \\
\hline Xileno & BTEX & $\mathrm{C}_{6} \mathrm{H}_{4}\left(\mathrm{CH}_{3}\right)_{2}$ & $\begin{array}{l}\text { Solvente } \\
\end{array}$ \\
\hline Zinco & Metal tóxico & $\mathrm{Zn}$ & Eletroerosão \\
\hline
\end{tabular}

TABELA 26 - Posto de servicos automotivos

\begin{tabular}{|c|c|c|c|}
\hline Substância & Gr. Contaminante & Fórmula & Uso \\
\hline Acenafteno & $\mathrm{PAH}$ & $\mathrm{C}_{10} \mathrm{H}_{6}\left(\mathrm{CH}_{2}\right)_{2}$ & Combustivel \\
\hline Antraceno & $\mathrm{PAH}$ & $\mathrm{C}_{6} \mathrm{H}_{4}(\mathrm{CH})_{2} \mathrm{C}_{6} \mathrm{H}_{4}$ & Combustivel \\
\hline Benzo (a) pireno & $\mathrm{PAH}$ & $\mathrm{C}_{20} \mathrm{H}_{12}$ & Combustivel \\
\hline Benzeno & BTEX & $\mathrm{C}_{6} \mathrm{H}_{6}$ & Detergentes sintéticos \\
\hline Chumbo & Metal tóxico & $\mathrm{Pb}$ & \\
\hline Clorobenzeno & Solv. Org. Hal. & $\mathrm{C}_{6} \mathrm{H}_{5} \mathrm{Cl}$ & \\
\hline Dibrometano & Solv. Org. Hal. & $\mathrm{CH}_{2} \mathrm{Br}_{2}$ & \\
\hline Dicloroetano & Solv. Org. Hal. & $\mathrm{ClCH}_{2} \mathrm{CH}_{2} \mathrm{Cl}$ & \\
\hline Diclorometano & Solv. Org. Hal. & $\mathrm{CH}_{2} \mathrm{Cl}_{2}$ & Desengraxante \\
\hline Diesel & Derivado de Petróleo & & \\
\hline Etilenoglicol & Álcool & $\mathrm{CH}_{2} \mathrm{OHCH}_{2} \mathrm{OH}$ & Fluido de freio \\
\hline Óxido de Etileno & Oxido & $\mathrm{CH}_{2} \mathrm{CH}_{2} \mathrm{O}$ & \\
\hline Fluoranteno & PAH & $\mathrm{C}_{6} \mathrm{H}_{10}$ & Combustivel \\
\hline Indeno & $\mathrm{PAH}$ & $\mathrm{C}_{8} \mathrm{H}_{6} \mathrm{O}$ & Combustivel \\
\hline Metanol & Álcool & $\mathrm{CH}_{3} \mathrm{OH}$ & Combustivel \\
\hline Oleo Mineral & Derivado de Petróleo & & \\
\hline Naftaleno & PAH & $\mathrm{C}_{10} \mathrm{H}_{8}$ & Combustível \\
\hline Hidroxido de Sódio & Outros Comp. Inorg. & $\mathrm{NaOH}$ & Sabão \\
\hline Percloroetileno & $\begin{array}{l}\text { Solv. Org. Hal. } \\
\end{array}$ & $\mathrm{Cl}_{2} \mathrm{C}: \mathrm{CCl}_{2}$ & \\
\hline Tetraclorometano & Solv. Org. Hal. & $\mathrm{CCl}_{4}$ & Desengraxante \\
\hline Tolueno & BTEX & $\mathrm{CH}_{3} \mathrm{C}_{6} \mathrm{H}_{5}$ & \\
\hline Tricloroetano & Solv. Org. Hal, & $\mathrm{CHCl}_{2} \mathrm{CH}_{2} \mathrm{Cl}$ & Solvente \\
\hline Triclorofenol & Solv. Org. Hal. & $\mathrm{C}_{6} \mathrm{H}_{2} \mathrm{Cl}_{3}$ & Solvente \\
\hline Xileno & BTEX & $\mathrm{C}_{6} \mathrm{H}_{4}\left(\mathrm{CH}_{3}\right)_{2}$ & Desengraxante \\
\hline
\end{tabular}




\begin{tabular}{|c|c|c|c|}
\hline \multicolumn{4}{|c|}{ TABELA 27 - Tratamento de superficies metálicas } \\
\hline Substância & Gr. Contaminante & Fórmula & Uso \\
\hline Ácido Cloridrico & Ácido & $\mathrm{HCl}$ & Limpeza \\
\hline Ácido fosfórico & Ácido & $\mathrm{H}_{3} \mathrm{PO}_{4}$ & Detergente, decapagem \\
\hline Acido Nitrico & Ácido & $\mathrm{HNO}_{3}$ & Corrosão de metais \\
\hline Ácido Sulfúrico & Ácido & $\mathrm{H}_{2} \mathrm{SO}_{4}$ & Corrosão de metais \\
\hline Amônia & Comp. Nitrogenado & $\mathrm{NH}_{4}$ & \\
\hline Anidrido Maleico & Acido & $\mathrm{HC}: \mathrm{CH}(\mathrm{O}) \mathrm{OC}(\mathrm{O})$ & Preservativo p/óleos e graxas \\
\hline Anilina & Comp. Nitrogenado & $\mathrm{C}_{6} \mathrm{H}_{5} \mathrm{NH}_{2}$ & Antioxidante \\
\hline Antimônio & Metal tóxico & $\mathrm{Sb}$ & \\
\hline Arsênio & Metal tóxico & As & Aditivo ligante \\
\hline Bário & Metal tóxico & $\mathrm{Ba}$ & Desoxidante \\
\hline Benzina & Derivado de Petróleo & & Solvente \\
\hline Bisulfeto de Carbono & Comp. Sulfurado & $\mathrm{CS}_{2}$ & Solvente \\
\hline Boro & Outros Comp. Inorg. & $\mathrm{B}$ & Desoxidante \\
\hline Bromo & Outros Comp. Inorg. & $\mathrm{Br}$ & Branqueamento \\
\hline Cádmio & Metal tóxico & $\mathrm{Cd}$ & Eletrodeposição de tintas \\
\hline Chumbo & Metal tóxico & $\mathrm{Pb}$ & \\
\hline Cianeto de Cálcio & Cianeto & $\mathrm{Ca}(\mathrm{CN})_{2}$ & Agente lixiviante \\
\hline Cianeto de Sódio & Cianeto & $\mathrm{NaCN}$ & Limpeza de metais \\
\hline Cloretos & Organohalogenado & & \\
\hline Clorofórmio & Solv. Org. Hal. & $\mathrm{CHCl}_{2}$ & Solvente \\
\hline Cromo & Metal tóxico & $\mathrm{Cr}$ & Elemento ligante \\
\hline DibenzoDioxinas policlorada & Dioxinas & & \\
\hline Diclorometano & Solv. Org. Hal. & $\mathrm{CH}_{2} \mathrm{Cl}_{2}$ & Solvente, desengraxante \\
\hline Estanho & Metal tóxico & $\mathrm{Sn}$ & \\
\hline Fenol & Fenol & $\mathrm{C}_{6} \mathrm{H}_{5} \mathrm{OH}$ & Solvente \\
\hline Fluoreto & PAH & $\mathrm{C}_{6} \mathrm{H}_{4} \mathrm{CH}_{2} \mathrm{C}_{6} \mathrm{H}_{4}$ & Combustivel \\
\hline Hidroxido de Potássio & Outros Comp. Org. & $\mathrm{KOH}$ & Surfactante \\
\hline Hidroxido de Sódio & Outros Comp. Inorg. & $\mathrm{NaOH}$ & Surfactante \\
\hline Manganês & Metal tóxico & $\mathrm{Mn}$ & Anticorrosivo \\
\hline Mercúrio & Metal tóxico & $\mathrm{Hg}$ & \\
\hline Níquel & Metal tóxico & $\mathrm{Ni}$ & Tintas eletro-protetivas \\
\hline Nitrito & Comp. Nitrogenado & & \\
\hline Percloroetileno & Solv. Org. Hal. & $\mathrm{Cl}_{2} \mathrm{C}: \mathrm{CCl}_{2}$ & Secante $p /$ metais \\
\hline Piridina & Comp. Nitrogenado & $\mathrm{N}(\mathrm{CH})_{4} \mathrm{CH}$ & Solvente \\
\hline Prata & Metal tóxico & $\mathrm{Ag}$ & \\
\hline Querosene & Derivado de Petróleo & & Solvente \\
\hline Selênio & Metal tóxico & $\mathrm{Se}$ & \\
\hline Sulfato & Comp. Sulfurado & & \\
\hline Sulfito & Comp. Sulfurado & & \\
\hline Tetraclorometano & Solv. Org. $\mathrm{Hal}$. & $\mathrm{CCl}_{4}$ & Desengraxante de metais \\
\hline Titânio & Metal tóxico & $\mathrm{Ti}$ & \\
\hline Tolueno & BTEX & $\mathrm{CH}_{3} \mathrm{C}_{6} \mathrm{H}_{5}$ & Solvente \\
\hline Tricloroetano & Organohalogenado & $\mathrm{CHCl}_{2} \mathrm{CH}_{2} \mathrm{Cl}$ & Desengraxante de metais \\
\hline Xileno & BTEX & $\mathrm{C}_{6} \mathrm{H}_{4}\left(\mathrm{CH}_{3}\right)_{2}$ & Solvente \\
\hline Zinco & Metal tóxico & $\mathrm{Zn}$ & \\
\hline
\end{tabular}


Anexo III

Preço das análises laboratoriais para investigação confirmatória CETESB - Mar/2001. 
1) Primeira linha de decisão: Preço para todas as áreas

\begin{tabular}{|c|c|c|c|c|c|}
\hline ATIVIDADE & $\begin{array}{l}\text { Nümero de } \\
\text { áreas } \\
\text { suspeitas }\end{array}$ & $\begin{array}{c}\text { Código } \\
\text { CETESB } \\
\text { parâmetros }\end{array}$ & $\begin{array}{l}\text { Estratégia } \\
\text { amostral } \\
\text { sugerida }\end{array}$ & $\begin{array}{c}\text { Preço de } \\
\text { amostra / ponto } \\
\text { (4 solo }+4 \\
\text { água) }\end{array}$ & TOTAL (R\$) \\
\hline $\begin{array}{l}\text { Comércio de } \\
\text { combustiveis } \\
\text { (atacado e } \\
\text { varejo) }\end{array}$ & $\begin{array}{c}15 \\
\text { (P000130, } \\
\text { P000191, } \\
\text { P000192, } \\
\text { P000193, } \\
\text { P000200, } \\
\text { P000201, } \\
\text { P000202, } \\
\text { P000231, } \\
\text { P000233, } \\
P 000235 \\
P 000236 \\
P 000237 \\
P 000238 \\
P 000239 \mathrm{e} \\
C 000232) \\
\end{array}$ & $\begin{array}{c}2167 \text { e } 2185 \\
2254 \text { e } 2735 \\
2385 \text { e } 2133 \\
0173 \text { e } 0958 \\
\text { e } 0212\end{array}$ & 4 & $\begin{array}{l}1.804,50+ \\
2.000,00^{\mathrm{b}}\end{array}$ & $246.540,00$ \\
\hline $\begin{array}{l}\text { Fabricação } \\
\text { de produtos } \\
\text { de alumínio }\end{array}$ & $\begin{array}{c}03 \\
(1000347 \\
1000348 \mathrm{e} \\
1000375)\end{array}$ & $\begin{array}{l}2167 \text { e } 2185 \\
1865,2252 \text { e } \\
2253,2506 \text { e } \\
2507,0173 \text { e } \\
0958,0188 \text { e } \\
1009,2385 \text { e } \\
2133 \text { e } 0210 .\end{array}$ & $\begin{array}{c}\text { A) } \\
1000347 \mathrm{e} \\
1000348= \\
1 \\
\text { B) } 1000375 \\
=4 .\end{array}$ & $\begin{array}{l}\text { A) Preço }= \\
\text { método de } \\
\text { varredura } \\
\text { adotado }+ \\
\text { parâmetros. } \\
\text { B) } 1.745,96^{b}\end{array}$ & $\begin{array}{c}\text { A) Preço = } \\
\text { método de } \\
\text { varredura } \\
\text { adotado + } \\
\text { parâmetros } \\
\text { B) } 15.967,68\end{array}$ \\
\hline Plásticos & $\begin{array}{c}06 \\
11000256 \\
1000329 \\
1000338 \\
1000344 \\
1000345 \mathrm{e} \\
1000380)\end{array}$ & $\begin{array}{c}2252 \text { e } 2253 \\
2506 \text { e } 2507 \\
2250 \text { e } 2251 \\
0173 \text { e } 0958 \\
\text { e } 2385 \text { e } \\
2133\end{array}$ & 4 & $\begin{array}{l}1.353,90+ \\
2.000,00^{\circ}\end{array}$ & $76.987,20$ \\
\hline $\begin{array}{l}\text { Produtos } \\
\text { químicos }\end{array}$ & $\begin{array}{c}01 \\
(1000283)\end{array}$ & $\begin{array}{c}2167 \mathrm{e} 2185 \\
1865,2252 \mathrm{e} \\
2253,2506 \mathrm{e} \\
2507,0173 \mathrm{e} \\
0958,2385 \mathrm{e} \\
2133,0210 \mathrm{e} \\
0212 . \\
\end{array}$ & 4 & $\begin{array}{l}1.223,24+ \\
2.000,00^{b}\end{array}$ & $11.785,92$ \\
\hline $\begin{array}{c}\text { Tratamento } \\
\text { de } \\
\text { superfícies } \\
\text { metálicas }\end{array}$ & $\begin{array}{c}06 \\
(1000277 \\
1000304 \\
1000315 \\
1000374 \\
1000385 \mathrm{e} \\
1000443)\end{array}$ & $\begin{array}{c}2167 \text { e } 2185 \\
1865,2252 \text { e } \\
2253,2506 \text { e } \\
2507,0131 \\
0173 \text { e } 0958 \\
0188 \text { e } 1009 \\
2385 \text { e } 2133 \\
0210 \\
\end{array}$ & 4 & $\begin{array}{l}1.250,44+ \\
2.000,00^{b}\end{array}$ & $72.021,12$ \\
\hline $\begin{array}{l}\text { Oficinas e } \\
\text { garagens de } \\
\text { veículos }\end{array}$ & $\begin{array}{c}07 \\
(C 000327 \\
C 000351 \\
C 000355 \\
C 000378, \\
C 000379 \mathrm{e} \\
\mathrm{C} 000386)\end{array}$ & $\begin{array}{c}2167 \text { e } 2185 \\
2254 \text { e } 2735 \\
2252 \text { e } 2253 \\
\text { e } 2385 \text { e } \\
2133\end{array}$ & 4 & $\begin{array}{l}1.712,75+ \\
2.000,00^{b}\end{array}$ & $109.914,00$ \\
\hline $\begin{array}{l}\text { Lava rápido } \\
\text { de veículos }\end{array}$ & 01 & $\begin{array}{r}1865,2252 \mathrm{e} \\
2253,2250 \mathrm{e}\end{array}$ & 4 & $\begin{array}{l}1.360,13+ \\
2.000,00^{b}\end{array}$ & $12.881,04$ \\
\hline
\end{tabular}




\begin{tabular}{|c|c|c|c|c|c|}
\hline & $(\mathrm{C} 000387)$ & $\begin{array}{l}2251,2385 \mathrm{e} \\
2133 \mathrm{e} 0212 .\end{array}$ & & & \\
\hline $\begin{array}{c}\text { Fundição / } \\
\text { Forjaria }\end{array}$ & $\begin{array}{c}03 \\
(1000302 \\
1000385 e \\
1000400)\end{array}$ & $\begin{array}{l}2167 \text { e } 2185, \\
2252 \text { e } 2253, \\
2506 \text { e } 2507, \\
0131,2250 \text { e } \\
2251,2385 \text { e } \\
2133 \text { e } 0210\end{array}$ & 4 & $\begin{array}{l}1.551,21+ \\
2.000,00^{b}\end{array}$ & $43.229,04$ \\
\hline $\begin{array}{l}\text { Tornearia / } \\
\text { estamparia / } \\
\text { fresa / dobra }\end{array}$ & $\begin{array}{c}10 \\
(1000277 \\
1000309 \\
1000312 \\
1000313 \\
1000315 \\
1000330 \\
1000337 \\
1000374 \\
1000383 \\
1000384 \\
1000392) \\
\end{array}$ & $\begin{array}{c}2167 \text { e } 2185 \\
1865,2252 \mathrm{e} \\
2253,0131 \\
0173 \text { e } 0958 \\
0188 \text { e } 1009 \\
\text { e } 2385 \mathrm{e} \\
2133\end{array}$ & 4 & $\begin{array}{l}888,40+ \\
2.000,00^{b}\end{array}$ & $91.072,00$ \\
\hline Móveis & $\begin{array}{c}02 \\
(1000303 \mathrm{e} \\
1000336)\end{array}$ & $\begin{array}{l}2167 \text { e } 2185 \\
1805 \text { e } 1807 \\
2385 \text { e } 2133\end{array}$ & 4 & $\begin{array}{l}1.526,44+ \\
2.000,00^{b}\end{array}$ & $28.423,04$ \\
\hline Óleos & $\begin{array}{c}02 \\
(1000314 \mathrm{e} \\
1000316) \\
\end{array}$ & $\begin{array}{l}2167 \text { e } 2185, \\
1865,2252 \text { e } \\
2253,2385 \text { e } \\
2133 \text { e } 0212 .\end{array}$ & 4 & $\begin{array}{l}1.056,09+ \\
2.000,00^{b}\end{array}$ & $20.897,44$ \\
\hline Cerâmica & $\begin{array}{c}01 \\
(1000323)\end{array}$ & $\begin{array}{l}2167 \text { e } 2185 \\
2252 \text { e } 2253\end{array}$ & 1 & $\begin{array}{c}\text { Preço }=\text { método } \\
\text { de varredura } \\
\text { adotado }+ \\
\text { parâmetros }\end{array}$ & $\begin{array}{c}\text { Preço }= \\
\text { método de } \\
\text { varredura } \\
\text { adotado }+ \\
\text { parâmetros }\end{array}$ \\
\hline Cemitério & $\begin{array}{c}01 \\
(0000388)\end{array}$ & $\begin{array}{l}2167 \text { e } 2185, \\
2385 \text { e } 2133 \\
\text { e análises de } \\
\text { patogênicos. }\end{array}$ & 4 & $\begin{array}{c}584,28^{b}+ \\
\text { análises de } \\
\text { patogênicos. }\end{array}$ & $\begin{array}{c}6.674,24+ \\
\text { análises de } \\
\text { patogênicos. }\end{array}$ \\
\hline & & & & & $\begin{array}{l}\text { TOTAL } \\
\text { R\$736.392, } \\
2\end{array}$ \\
\hline
\end{tabular}
a) A Estratégia 4 (item 4.1.7) foi modificada para um ponto por fonte de contaminação ao invés de se utilizar
quatro pontos.

b) Preço de amostragem utilizando-se Geoprobe com mão de obra e frascos: $R \$ 50,00$ (Cinqüenta Reais) / metro linear, profundidade estimada por ponto $=10$ metros, 4 pontos por área. Preço $/$ área $=R \$ 2.000,00$.

c) Não foram cotados os preços para Compostos Orgânicos Voláteis - VOC. 
2) Segunda linha de decisão: Preço para as áreas priorizadas pela utilização do sistema de pontuação.

\begin{tabular}{|c|c|c|c|c|c|}
\hline ATIVIDADE & $\begin{array}{l}\text { Número de } \\
\text { áreas } \\
\text { suspeitas }\end{array}$ & $\begin{array}{c}\text { Código } \\
\text { CETESB } \\
\text { parâmetros }\end{array}$ & $\begin{array}{l}\text { Estratégia } \\
\text { amostral } \\
\text { sugerida }\end{array}$ & $\begin{array}{c}\text { Preço de } \\
\text { amostra / ponto } \\
\text { (4 solo }+4 \\
\text { água) }\end{array}$ & TOTAL (R\$) \\
\hline $\begin{array}{l}\text { Comércio de } \\
\text { combustiveis } \\
\text { (atacado e } \\
\text { varejo) }\end{array}$ & $\begin{array}{c}15 \\
\text { (P000130, } \\
P 000191, \\
P 000192 \\
P 000193 \\
P 000200 \\
P 000201 \\
P 000202 \\
P 000231 \\
P 000233 \\
P 000235 \\
P 000236 \\
P 000237 \\
P 000238 \\
P 000239 \\
C 000232) \\
\end{array}$ & $\begin{array}{c}2167 \text { e } 2185 \\
2254 \text { e } 2735 \\
2385 \text { e } 2133 \\
0173 \text { e } 0958 \text { e } \\
0212\end{array}$ & 4 & $\begin{array}{l}1.804,50+ \\
2.000,00^{b}\end{array}$ & $246.540,00$ \\
\hline $\begin{array}{l}\text { Fabricação } \\
\text { de produtos } \\
\text { de alumínio }\end{array}$ & $\begin{array}{c}03 \\
(1000347 \\
1000348 \mathrm{e} \\
1000375) .\end{array}$ & $\begin{array}{l}2167 \text { e } 2185 \\
1865,2252 \mathrm{e} \\
2253,2506 \mathrm{e} \\
2507,0173 \mathrm{e} \\
0958,0188 \mathrm{e} \\
1009,2385 \mathrm{e} \\
2133 \mathrm{e} 0210 .\end{array}$ & $\begin{array}{c}\text { A) } \\
1000347 \mathrm{e} \\
1000348= \\
1 \\
\text { B) } 1000375 \\
=4 .\end{array}$ & $\begin{array}{l}\text { A) Preço }= \\
\text { método de } \\
\text { varredura } \\
\text { adotado + } \\
\text { parâmetros. } \\
\text { B) } 1.745,96^{b}\end{array}$ & $\begin{array}{c}\text { A) Preço }= \\
\text { método de } \\
\text { varredura } \\
\text { adotado }+ \\
\text { parâmetros } \\
\text { B) } 15.967,68 \\
\end{array}$ \\
\hline Plásticos & $\begin{array}{c}01 \\
(1000380)\end{array}$ & $\begin{array}{c}2252 \text { e } 2253 \\
2506 \text { e } 2507, \\
2250 \text { e } 2251 \\
0173 \text { e } 0958 \text { e } \\
2385 \text { e } 2133 .\end{array}$ & 年 & $\begin{array}{l}1.353,90+ \\
2.000,00^{b}\end{array}$ & $12.831,20$ \\
\hline $\begin{array}{l}\text { Produtos } \\
\text { químicos }\end{array}$ & $\begin{array}{c}01 \\
(1000283)\end{array}$ & $\begin{array}{c}2167 \text { e } 2185, \\
1865,2252 \mathrm{e} \\
2253,2506 \mathrm{e} \\
2507,0173 \mathrm{e} \\
0958,2385 \mathrm{e} \\
2133,0210 \mathrm{e} \\
0212 .\end{array}$ & 4 & $\begin{array}{l}1.223,24+ \\
2.000,00^{b}\end{array}$ & $11.785,92$ \\
\hline $\begin{array}{c}\text { Tratamento } \\
\text { de } \\
\text { superfícies } \\
\text { metálicas }\end{array}$ & $\begin{array}{c}05 \\
(1000277 \\
1000304 \\
1000315 \\
1000374 \\
1000385)\end{array}$ & $\begin{array}{c}2167 \text { e } 2185 \\
1865,2252 \text { e } \\
2253,2506 \text { e } \\
2507,0131 \\
0173 \text { e } 0958 \\
0188 \text { e } 1009 \\
2385 \text { e } 2133 \\
0210\end{array}$ & 4 & $\begin{array}{l}1.250,44+ \\
2000,00^{\mathrm{b}}\end{array}$ & $60.017,60$ \\
\hline $\begin{array}{c}\text { Oficinas e } \\
\text { garagens de } \\
\text { veículos }\end{array}$ & $\begin{array}{c}02 \\
(\mathrm{C} 000355 \mathrm{e} \\
\mathrm{C} 000379)\end{array}$ & $\begin{array}{c}2167 \text { e } 2185 \\
2254 \text { e } 2735 \\
2252 \text { e } 2253 \text { e } \\
2385 \text { e } 2133\end{array}$ & 4 & $\begin{array}{l}1.712,75+ \\
2.000,00^{b}\end{array}$ & $31.404,00$ \\
\hline $\begin{array}{l}\text { Fundição / } \\
\text { Forjaria }\end{array}$ & $\begin{array}{c}03 \\
(1000302 \\
1000385 \mathrm{e} \\
1000400)\end{array}$ & $\begin{array}{l}2167 \text { e } 2185 \\
2252 \text { e } 2253 \\
2506 \text { e } 2507 \\
0131,2250 \text { e } \\
2251,2385 \text { e } \\
2133 \text { e } 0210\end{array}$ & 4 & $\begin{array}{l}1.551,21+ \\
2.000,00^{\circ}\end{array}$ & $43.229,04$ \\
\hline $\begin{array}{c}\text { Tornearia / } \\
\text { estamparia / } \\
\text { fresa / dobra } \\
\end{array}$ & $\begin{array}{c}10 \\
(1000277 \\
\end{array}$ & $\begin{array}{c}2167 \text { e } 2185 \\
1865,2252 \text { e } \\
2253,0131 \\
\end{array}$ & 4 & $\begin{array}{c}888,40+ \\
2.000,00^{b}\end{array}$ & $91.072,00$ \\
\hline
\end{tabular}




\begin{tabular}{|c|c|c|c|c|c|}
\hline & $\begin{array}{l}1000309, \\
1000312, \\
1000313 \\
1000315 \\
1000330 \\
1000337 \\
1000374 \\
1000383 \\
1000384 \\
1000392)\end{array}$ & $\begin{array}{l}0173 \text { e } 0958 \\
0188 \text { e } 1009 \text { e } \\
2385 \text { e } 2133\end{array}$ & & & \\
\hline Móveis & $\begin{array}{c}01 \\
(1000303) .\end{array}$ & $\begin{array}{l}2167 \text { e } 2185 \\
1805 \text { e } 1807 \\
2385 \text { e } 2133\end{array}$ & 4 & $\begin{array}{l}1.526,44+ \\
2.000,00^{\mathrm{b}}\end{array}$ & $14.211,52$ \\
\hline Óleos & $\begin{array}{c}02 \\
(1000314 \mathrm{e} \\
1000316) \\
\end{array}$ & $\begin{array}{l}2167 \text { e } 2185, \\
1865,2252 \text { e } \\
2253,2385 \text { e } \\
2133 \text { e } 0212 .\end{array}$ & 4 & $\begin{array}{l}1.056,09+ \\
2.000,00^{b}\end{array}$ & $20.897,44$ \\
\hline & & & & & $\begin{array}{l}\text { TOTAL RS } \\
547.956,40\end{array}$ \\
\hline
\end{tabular}

a) A Estratégia 4 (item 4.1.7) foi modificada para um ponto por fonte de contaminação ao invés de se utilizar quatro pontos.

b) Preço de amostragem utilizando-se Geoprobe com mão de obra e frascos: $R \$ 50,00$ (Cinqüenta Reais) / metro linear, profundidade estimada por ponto $=10$ metros, 4 pontos por área. Preço $/$ área $=R \$ 2.000,00$.

c) Não foram cotados os preços para Compostos Orgânicos Voláteis - VOC.

Códigos CETESB e preços das análises laboratoriais.

\begin{tabular}{|c|c|c|}
\hline Código CETESB & Análise / Descrição & Preco (R\$) / Marco 2001 \\
\hline 2167 & 10 Metais $A / B / C$ (total ou solúvel) & 107,80 \\
\hline 2185 & 10 Metais D & 124,27 \\
\hline 1865 & Ácidos voláteis & 129,71 \\
\hline 2254 & Benzo (a) pireno A/B & 364,30 \\
\hline 2735 & Benzo (a) pireno $D$ & 449,35 \\
\hline 1805 & Blocidas clorados A/B & 381,16 \\
\hline 1807 & Biocidas clorados $\mathrm{D}$ & 561,00 \\
\hline 2252 & BTX A/B & 86,09 \\
\hline 2253 & $\mathrm{BTX} C / \mathrm{D}$ & 228,73 \\
\hline 2506 & Cianeto $B$ & 42,38 \\
\hline 2507 & Cianeto $C / D$ & 43,11 \\
\hline 0131 & Cromo hexavalente A/B/C & 13,31 \\
\hline 2250 & Fenóis PCP/2,4,6 Tric. Fenol A/B & 230,59 \\
\hline 2251 & Fenóls PCP/2, 4,6 Tric Fenol $\mathrm{C} / \mathrm{D}$ & 305,52 \\
\hline 0173 & Mercúrio A/B/C (total ou solúvel) & 28,57 \\
\hline 0958 & (ै। Mercúrio D & 35,89 \\
\hline 0188 & $\mathrm{pH} \mathrm{A/B/C}$ & 5,09 \\
\hline 1009 & ४ $\mathrm{pH}$ D & 8,80 \\
\hline 2385 & Solventes halogenados $A / B$ & 99,03 \\
\hline 2133 & Solventes halogenados CID & 253,18 \\
\hline 0210 & Sulfato $A / B / C$ & 17,20 \\
\hline 0212 & Surfactantes $\mathrm{A} / \mathrm{B} / \mathrm{C}$ & 2728 \\
\hline
\end{tabular}

